UNITED STATES DEPARTMENT OF THE INTERIOR

Harold L. Ickes, Secretary

GEOLOGICAL SURVET

W. C. Mendenhall, Director

\title{
Bulletin 846
}

\section{CONTRIBUTIONS TO ECONOMIC GEOLOGY}

(SHORT PAPERS AND PRELIMINARY REPORTS)

\section{3}

G. F. LOUGHLIN

GEOLOGIBT IN CHARGE
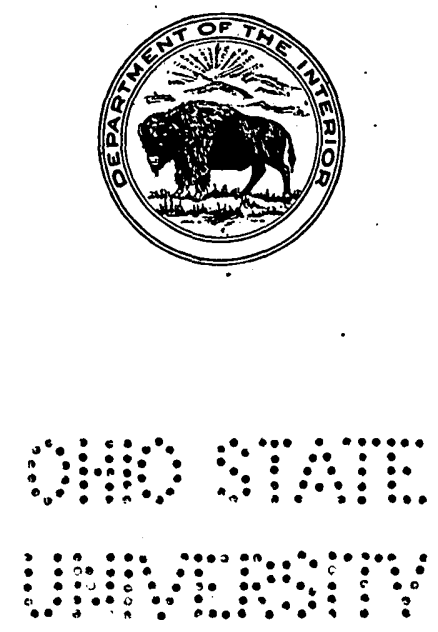

UNITED S'CATES

(i1) VERNMENT PRINTING OFFICE

WASHINGTON : 1934 
QE 75

B9

$n 0.846$

copay?

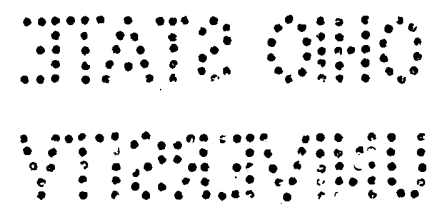




\section{CONTENTS}

[The letters in parentheses preceding the titles are those used to designate the papers for adrance publication ]

(A) Some mining districts of eastern Oregon, by James Gilluly, J. C. Reed, and C. F. Park, Jr.

Page

(B) Geology and ore deposits of the Takilma-Waldo district, Oreg., including the Blue Creek district, by Philip J. Shenon.

(C) The Climax molybdenum deposit, Colorado, by B. S. Butler and J. W. Vanderwilt, with a section on history, production, metallurgy, and development by Charles W. Henderson

(D) Some lode deposits in the northwestern part of the Boise Basin, Idaho, by Clyde P. Ross

\section{ILLUSTRATIONS}

Plate 1. Index map showing location of mining districts in eastern Oregon.

2. Topographic and geologic map of the Mormon Basin mining district, Baker and Malheur Counties, Oreg-................

3. Geologic sketch of underground workings of Amalgamated Mines Co., East Eagle district, Oreg-........................

4. Topographic and geologic map of Virtue district, Baker County, Oreg-

5. Sketch map of mill-tunnel level of Virtue mine, Virtue district, Oreg

6. Composite plan and section of Flagstaff mine, Virtue district, Oreg.

7. Map and section of Standard mine, Quartzburg district, Oreg---

8. Geologic sketch map of Gold Hill and vicinity, Ochoco Creek area, Oreg-

9. Index map of southwestern Oregon and northwestern California

10. Topographic map of Takilma-Waldo district, Oreg., and vicinity

11. Geologic map of Takilma-Waldo district, Oreg-...............-

12. $A$, Cretaceous conglomerate and sandstone lenses; $B$, Spheroidal weathering in Cretaceous sandstone

13. $A$, Tertiary conglomerate resting on greenstone at High Gravel mine; $B$, Tertiary conglomerate with sandstone lenses at Platerica mine. 
Plate 14. A, Gravel of Llano de Oro formation resting on Tertiary conglomerate at Llano de Oro mine; $B$, Serpentine bedrock at Llano de Oro mine.

15. Plan of north-end workings of Queen of Bronze mine

16. $A$, Tabular body of sulphide ore terminated by a fault, Queen of Bronze mine; $B$, Boulder ore from Cowboy mine

17. $A, B$, Photomicrographs of ore from Queen of Bronze mine.-.--

18. Plan and sections of part of Cowboy mine

19. $A, B$, Photomicrographs of ore from Cowboy mine

20. $A, B$, Photomicrographs of ore from Cowboy mine

21. $A$, Chromite deposit in serpentine, Llano de Oro mine; $B$, 174 Hydraulic elevators used to lift water and tailings from placer pits, Llano de Oro mine; $C$, Undercurrents for saving fine gold and platinum, Llano de Oro mine

22. $A$, Leached outcrop at Turner mine; $B$, Quartz-zeolite veinlets in Tertiary conglomerate, Platerica mine

23. Geologic map and sections of Climax molybdenum district_- In pocket

24. $A$, Climax district in winter; $B$, Panorama of a part of Mos-

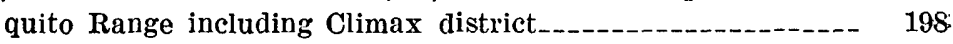

25. Recrystallized schist__._._.

26. Secondary orthoclase

27. $A$, Orthoclase replacing muscovite; $B$, Pyrite vein with topaz gangue

28. Molybdenite veins.

29. Molybdenite veins

30. Molybdenite-quartz veins_-_-_-_-_-_-_-_-_-_-_-_-_- 222

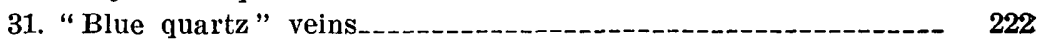

32. Detailed map of Climax molybdenum district__-_._-_._....- In pocket

33-37. Cross sections of molybdenum deposit_..._-_-_-_-_-_- In pocket

38. Content of molybdenum as sulphide and oxide in some dia-

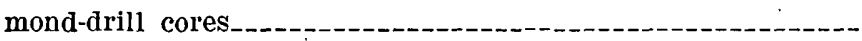

39. Claim map of the central and western parts of the Boise Basin, Idaho

40. Geologic map of the Quartzburg area, Boise basin 242

41. $A$, Dacite porphyry, Gold Hill mine; $B$, Rhyolite porphyry, Gold Hill mine; $C$, Granite porphyry, Belshazzar mine-_-_-- 250

42. Granophyre porphyry

43. Composite level map of the Gold Hill mine-_-_-_-_-_-_- In pocket.

44. Geologic maps of the 250, 400, and 700 levels, Gold Hill mine

45. Diagrammatic geologic sections through the Gold Hill mine

In pocket

In pocket

46. Photomicrographs of ore from the Gold Hill mine, showing relations between the native gold and the bismuth minerals_- 266

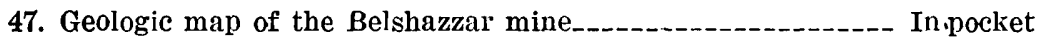

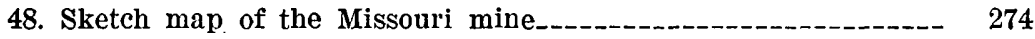

Figure 1. Geologic map of Sunday Hill mine, Mormon Basin, Oreg-..-- 40

2. Geologic map of the Randall mine, Mormon Basin, Oreg

3. Geology of tunnel on Overshot group, Mormon Basin, Oreg-- $\quad .43$

4. Geology of the Summit Mining \& Milling Co.'s tunnel, Mormon Basin, Oreg 
Fraure 5. Tunnel on Hice prospect, Mormon Basin, Oreg

6. Map of the workings of the Gold Hill mine, near Durkee, - Oreg.

7. Map of the Crystal Palace mine, near Sparta, Oreg-

8. Map of the Macy mine, Sparta district, Oreg-

9. Map of the Basin mine, Sanger district, Oreg

10. Map of the workings of the Black Prince prospect, near Dixie Butte, Quartzburg district, Oreg-

11. Geologic map of third level, Colorado vein, Equity group, Quartzburg district, Oreg-

12. Workings of Paul Tote prospect, Quartzburg district, Oreg--

13. Workings on lower tunnel level, Yankee Boy vein, Quartzburg district, Oreg-

14. Geology of New Forrester tunnel, Forrester group, Quartzburg district, Oreg.

15. Map of Copperopolis mine, Quartzburg district, Oreg--.--.--

16. Paragenesis of minerals in Susanville district, Oreg., as shown by studies of polished sections of ore

17. Map of Princess prospect, Susanville district, Oreg

18. Map of workings, Belle of the Hills prospect, Susanville district, Oreg-

19. Map showing location of deposits in the Ochoco district, Oreg., described in this report.

20. Map of main level, Quicksilver Consolidated Mining Co.'s mine, Ochoco district, Oreg

21. Sketch map of lower tunnel, Ophir-Mayflower mine, Ochoco Creek, Oreg.

22. Section illustrating relation of Tertiary conglomerate to bedrock series, Takilma-Waldo district, Oreg-

23. Sections through Hampshire stope on $D$ level of Queen of Bronze mine

24. Plan of workings of Waldo mine

25. Geologic map of Blue Creek district.

26: Map showing relation of part of underground workings to leached outcrops at Turner mine

27. Section of the Weber and Maroon formations in the area northwest of the Tenmile district and east of Red Cliff

28. Idealized representation of Climax molybdenum pipe or stock-

29. Climax molybdenum deposit in block diagram

30. Molybdenite content in drift 2, Phillipson level_.............-

31. Changes in the alteration of pre-Cambrian Silver Plume granite

32. Index map of Idaho showing the location of the Boise Basin -

33. Longitudinal vertical projection through the Gold Hill mine

34. Idealized diagram of an ore body in the Pioneer workings of the Gold Hill mine.

35. Sketch map of the Mayflower mine 


\title{
UNITED STATES DEPARTMENT OF THE INTERIOR
}

Harold L. Ickes, Secretary

GEOLOGICAL SURVEY

W. C. Mendenhall, Director

\section{Bulletin 846-A}

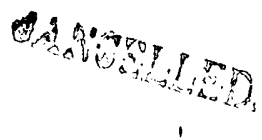

\section{SOME MINING DISTRICTS OF EASTERN OREGON}

\author{
BY \\ JAMES GILLULY, J. C. REED \\ AND \\ C. F. PARK, JR. \\ 1 \\ Prepared in cooperation with the \\ OREGON STATE MINING BOARD
}

Contributions to economic geology, 1933, Part 1

(Pages 1-140)



UNITED STATES

GOVERNMENT PRINTING OFFICE

WASHINGTON : 1933

For Sale by the Superintendent of Documents, Washington, D. C. - - - - - Price 25 cents 



\section{CONTENTS}

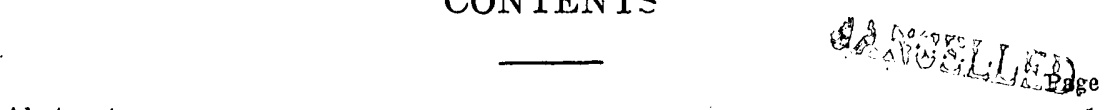

Abstract

Introduction

Outline of project................. 3

Geography

Previous work

General geology

General features.

Rock units................ 10

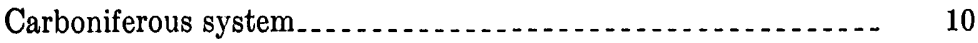

Triassic system $\ldots \ldots \ldots \ldots$

Jurassic system

Cretaceous system

Strata of unknown but pre-Tertiary age

Tertiary system

Quaternary system................................ 17

Plutonic rocks

General features................................. 17

Serpentine........... 18

Other ultrabasic rocks. $\ldots \ldots \ldots$

Gabbro, diabase, and norite..................... 19

Diorite

Quartz diorite and granodiorite................... 20

Albite granite $\ldots \ldots$

Structure $\ldots \ldots \ldots \ldots \ldots$

Pre-Tertiary structure

Pre-Tertiary unconformity $\ldots \ldots \ldots$

Tertiary folding and faulting



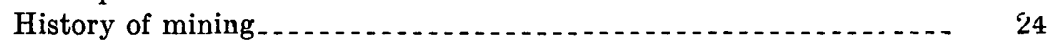

Produotion.................................................... 25

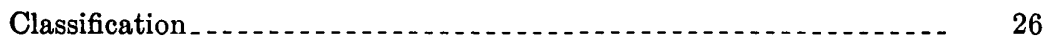

Magmatic relations of the deposits

General economic considerations. ........................ 29

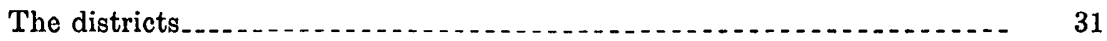

Mormon Basin

Geography .

Field work

Geology

General features.

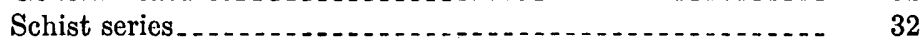

Basic intrusive rocks............................... 33

Quartz diorite and related rocks............. 34

Tertiary rocks (Miocene?)

Quaternary rocks.

Structure 
The districts-Continued.

Mormon Basin-Continued. Page

Ore deposits....... 37

The mines._.......... 37

Rainbow

Sunday Hill. . . .

Randall

Overshot. 43

Summit.... . .

Humboldt.... . .

Hice

Blue Mud.......... 47

Intermountain

Cleveland Development Co.......... 47

Giraffe............. 48

Morton......

Other prospects...... 48

Placer mines.......

Outlook for the district.

Connor Creek district._... 49

Geography $\ldots \ldots \ldots$

Field work . .

Geology $\ldots \ldots \ldots$

The mines....

Connor Creek . .

Liddy

Mullin

Runner

Placer mines......... 52

Bay Horse.......... 52

Outlook for the district.

Gold Hill district............ 54

Location and geology

The mines. .

Gold Hill . .

Durkee Development Co..._.

Gold Ridge................ 56

Outlook for the district. ............. 57

Sparta district._. 57

Geography

Geology

The mines.... 58

Gem......... 58

Crystal Palace...

Macy

Placer mines.....

Thomas........... 62

Outlook for the district.

East Eagle district.

Location and general features.... 63

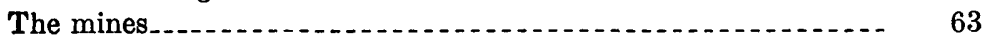

Amalgamated Mines Co. 63 
The districts-Continued.

East Eagle district-Continued.

The mines-Continued.

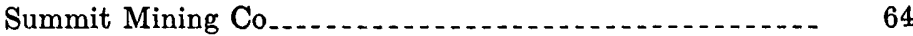

Midway

Apex

Zenith

Woodrow

Summit...

Outlook for the district.

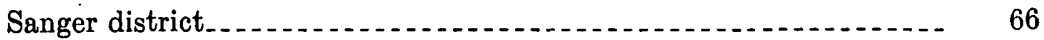



Basin

Medical Springs district.......... 69

Location and geology ........



Twin Baby ...

Grull

Outlook for the district.

Virtue district._.

Geography

Field work . . .

Geology

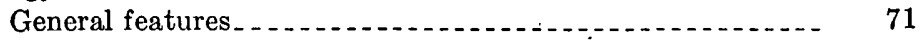

Ore deposits

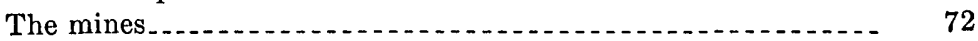

Virtue

Flagstaff.

Koehler.............. 76

Norwood

Cliff

White Swan

Chicago-Virtue.....

Carroll B. .

Brazos........ 79

Other prospects... 79

Outlook for the district.

Baker district. .

Geography . . 80

Geology ....

Ore deposits

The mines..... 81

Tom Paine

Old Soldier... 82

Marble Creek Mining \& Milling Co

Yellow Boy Mining Co

Stub...

Sorbeck

Dale

Placer mines..........

Outlook for the district 
The districts-Continued. . Page

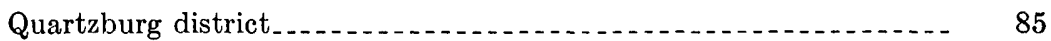

Geography .

Geology

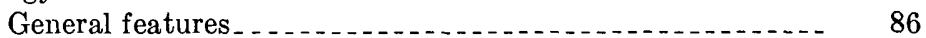

Ore deposits

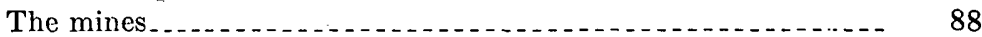

Dixie Meadows

Last Chance

Black Prince.

Equity

Present Need......... 93

Paul Tote.

Klondike........ 94

Cougar. . .

Yankee Boy

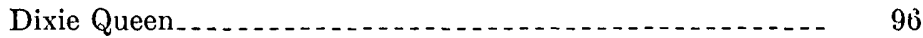

Fitzsimmons

Forrester

Andrew Jackson . .



Howell \& Haight............ 98

Copper Mountain Mining Co............ 99

Copperopolis.............. 100

Standard

Dixie Creek placers.....

Comini quarries.......... 104

Outlook for the district.

Susanville district.

Geography

Field work .....

Geology

General features.

Schist series . .

Basic intrusive rocks . . . . . . . 107

Quartz diorite and related dikes........ 107

Tertiary rocks (Miocene)

Quaternary rocks.

Structure $\ldots$

Ore deposits...

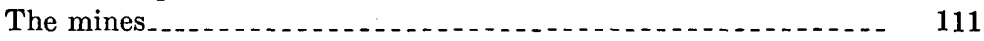

Badger

Gem.

Bull of the Woods. 112

Rescue

Chattanooga $\ldots \ldots \ldots$

Daisy

Princess_._.

Poorman

Belle of the Hills...

Gold Bug.

Mocking Bird. . . 116

Ophir._.

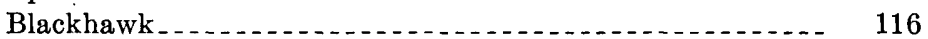


The districts-Continued.

Susanville district-Continued.

The mines-Continued. Page

Side Issue ... . . . . . . . . . 116

Simcox...

Skyscraper.

Thompson . . . .

Stockton

Nelson....

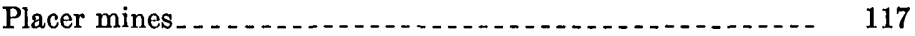

Outlook for the district. . . . . 118

Ochoco district................ 118

Geography $\ldots \ldots \ldots$

The mines . . . . . .

Johnson Creek-Lookout Mountain area. . . . . . . . . . 120

Paulsen \& Saylor. . . . . . . . . . . . . . . . . . . . . . 120

Westerling . . .

Quicksilver Consolidated Mining Co........... 121

Marks Creek area, Wheeler County ................... 123

Bear

Ochoco Creek area, by G. F. Loughlin and James Gilluly_- 123

Champion

Gold Hill and vicinity (Howard district) ............ 124

Location and topography . . . .

Production..................... 125

Geology $\ldots \ldots \ldots$

Ore deposits................. 127

Ophir-Mayflower............. 133

Other workings on Gold Hill . . . . . . . . . . . 136

Red Bird Hill. . . . . . . . . . . . . . . . 137

Placers. . . .

Maury Mountain area.............. 138

Staley \& Towner............... 138

Bear Creek area.... 138

Wiltsie \& Platner.

Dunham

Outlook for the district.

\section{ILLUSTRATIONS}

Plate 1. Index map showing location of mining districts in eastern Oregon.

2. Topographic and geologic map of the Mormon Basin mining district, Baker and Malheur Counties, Oreg

3. Geologic sketch of underground workings of Amalgamated Mines Co., East Eagle district, Oreg..................

4. Topographic and geologic map of Virtue district, Baker County,

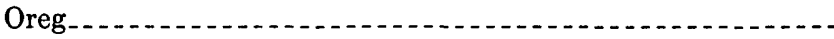

5. Sketch map of mill-tunnel level of Virtue mine, Virtue district, Oreg-

6. Composite plan and section of Flagstaff mine, Virtue district, Oreg-

7. Map and section of Standard mine, Quartzburg district, Oreg--

8. Geologic sketch map of Gold Hill and vicinity, Ochoco Creek area, Oreg- 
Frgure 1. Geologic map of Sunday Hill mine, Mormon Basin, Oreg.-.-

2. Geologic map of the Randall mine, Mormon Basin, Oreg....

3. Geology of tunnel on Overshot group, Mormon Basin, Oreg--

4. Geology of the Summit Mining \& Milling Co.'s tunnel, Mormon Basin, Oreg . .

5. Tunnel on Hice prospect, Mormon Basin, Oreg ........... 46

6. Map of the workings of the Gold Hill mine, near Durkee, Oreg

7. Map of the Crystal Palace mine, near Sparta, Oreg........

8. Map of the Macy mine, Sparta district, Oreg ...........

9. Map of the Basin mine, Sanger district, Oreg

10. Map of the workings of the Black Prince prospect, near Dixie Butte, Quartzburg district, Oreg .............

11. Geologic map of third level, Colorado vein, Equity group, Quartzburg district, Oreg

12. Workings of Paul Tote prospect, Quartzburg district, Oreg - -

13. Workings on lower tunnel level, Yankee Boy vein, Quartz-

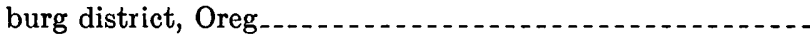

14. Geology of New Forrester tunnel, Forrester group, Quartz-

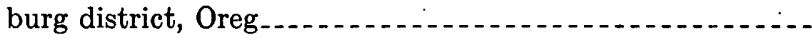

15. Map of Copperopolis mine, Quartzburg district, Oreg-...--

16. Paragenesis of minerals in Susanville district, Oreg., as shown by studies of polished sections of ore.....

17. Map of Princess prospect, Susanville district, Oreg.........

18. Map of workings, Belle of the Hills prospect, Susanville dis-

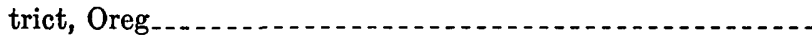

19. Map showing location of deposits in the Ochoco district, Oreg., described in this report.........

20. Main level, Quicksilver Consolidated Mining Co.'s mine,

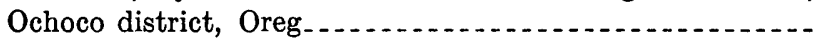

21. Sketch map of lower tunnel, Ophir-Mayflower mine, Ochoco Creek, Oreg

NoTE-Bulletin 846 will not be issued as a complete volume, but the last chapter will contain a volume title page and index for the use of those who may wish to bind together the separate chapters. 


\title{
SOME MINING DISTRICTS OF EASTERN OREGON
}

\author{
By James Gilluly, J. C. Reed, and C. F. Park, Jr.
}

\begin{abstract}
This report presents the results of a reconnaissance of most of the mining districts of Oregon east of the Cascade Range, with the exception of the districts in the Sumpter quadrangle. The districts described are distributed through an area roughly coincident with the Blue Mountains, which extend over much of the northeast quarter of the State.

The geology of the Blue Mountains, except for certain small areas, is known only in its most general outlines. The most widespread rocks are the Tertiary volcanic rocks, which extend over a very large part of the State. They are separated by a profound angular and erosional unconformity from the preTertiary rocks.

The pre-Tertiary rocks include representatives of all the geologic periods from Carboniferous to Cretaceous, and earlier periods may also be represented.

The known Carboniferous rocks include argillite, chert, greenstone, and subordinate limestone of uncertain age and a thick series of Permian greenstone, tuff, and limestone. The Triassic rocks include shale, slate, and limestone; the Jurassic rocks are shale and slate; and the Cretaceous are conglomerate and sandstone. Schist and phyllite with some limestone and greenstone of uncertain age occur along the Burnt River west of Durkee and in the Mormon Basin.
\end{abstract}

Intrusive rocks of at least two magmatic cycles are widespread in the Blue Mountains, and the stratigraphy suggests that several cycles may be represented. The older intrusive rocks include gabbro, pyroxenite, norite, dunite, hornblende-quartz diorite, and albite granite and are characterized by a considerable degree of shearing and both cataclastic and metasomatic metamorphism. The age of some of these rocks in the Canyon Range has been fixed as Lower or Middle Triassic, and others are known to be post-Triassic. Younger biotite-quartz diorite and granodiorite of post-Triassic (possibly postJurassic) age are widespread, and the ore deposits of pre-Tertiary age are believed to be genetically related to these rocks.

Representatives of the Tertiary period include Eocene volcanic rocks and sediments, Oligocene fluviatile deposits, Miocene basic lavas and fluviatile and lacustrine sediments, and Pliocene tuff and gravel. The Quaternary deposits include glacial moraines in the higher mountains, stream gravel, and volcanic ash.

The structure of the pre-Tertiary rocks is complex. Folds are characteristically close or isoclinal and strike eastward. The post-Permian rocks appear to be less metamorphosed and less strongly deformed than the earlier rocks, and the Jurassic less than the Triassic. More than one epoch of diastrophism is therefore involved. 
The topography of the region is controlled by the structure imposed in Tertiary time. Characteristically the structural features trend northwestward in the eastern areas, but in the south and west they trend westward. Both folding and faulting along these structural lines have continued until relatively recent, possibly postglacial time.

Mining began in the Blue Mountains in 1861 with the discovery of the placer deposits at Auburn. Within a few years most of the surrounding region had been thoroughly combed for placer gold. Lode mines were located in these days also, but little work was done on them until the completion of the transcontinental railroad in 1885. The most active period in lode mining was from about 1913 to 1918 , but since then there has been a rather steady decline, due in large part, at least, to higher costs of mining. The total production of gold and silver from the Blue Mountains has been about $\$ 80,000,000$, fully $\$ 75,000,000$ of which was in gold.

Small amounts of copper have been mined in connection with the gold for many years, and between 1915 and 1928 several properties at Homestead, on the Snake River, were operated primarily for their copper. During these years the copper production of Baker County amounted to over $14,000,000$ pounds, valued at about $\$ 2,400,000$. There has also been considerable prospecting for copper and a nominal production from mines near Keating in the lower Powder Valley.

Considerable chromite was mined during the World War and the years immediately following in Grant County, chiefly from the Strawberry Range, and in Baker County from deposits near Sumpter and from Connor Creek.

A few flasks of mercury have been produced from the Ochoco Mountains, at intervals since 1906, but not until 1929 has there been widespri ad activity in this region.

The ore deposits other than placers in eastern Oregon include gold, goldsilver, copper-gold, quicksilver, chromite, and manganese deposits.

Of these classes, the gold deposits are most widely represented. Goldsilver deposits are few; copper-gold deposits, in which the value of the copper exceeds that of the gold, are represented by the prospects in the Keating copper district and by those in the Homestead district on the Snake River, neither of which is considered in this bulletin, and by the Copperopolis property at Quartzburg. Quicksilver deposits are limited to the western part of the area, in the Ochoco country. Chromite deposits, not here described, occur in the Strawberry Range and on Connor Creek, and manganese deposits, all of superficial origin, are present near Durkee and Pleasant Valley.

The deposits occur predominantly as fissure veins or replacement veins. Stockworks and impregnation zones are represented by all the copper-gold deposits and possibly by the Rainbow gold mine in the Mormon Basin. Some of the chromite deposits are probably due to segregation; other's to impregnation.

Mineralogically the gold deposits are generally simple, carrying pyrite, pyrrhotite, chalcopyrite, galena, sphalerite, and arsenopyrite in a gangue of quartz, ankerite, calcite, and locally sericite, chlorite, serpentine, scheelite, fuchsite, barite, and clays.

Most of the copper deposits carry chalcopyrite, pyrite, galena, sphalerite, and arsenopyrite in a quartz-barite gangue with some chlorite and epidote, but the Copperopolis deposit carries considerable tourmaline as the principal associate of quartz in the gangue. 
The quicksilver deposits are composed of cinnabar with pyrite in a gangue of quartz, chalcedony, opal, chlorite, nontronite, calcite, dolomite, several clays, and asphalt.

The mineral deposits, considered genetically, appear to fall into three groups, each related to a different suite of igneous rocks. Two of these are of pre-Tertiary age; the third is middle or later Tertiary.

The chromite deposits, "as is the rule elsewhere, are all directly associated with ultrabasic rocks, dunite and pyroxenite, which have been thought to represent the earliest of the pre-Tertiary magmatic cycles.

By far the most of the gold deposits are situated in close juxtaposition with bodies of biotite-quartz diorite, and these deposits are therefore considered to be genetically related to the latest pre-Tertiary intrusive cycle, or, if only one pre-Tertiary cycle should prove to be represented in the region, to the latest intrusions of that cycle.

The quicksilver deposits of the Ochoco region and at least one gold deposit, the Ophir-Mayflower, occur in Tertiary rocks and hence are obviously related to much younger magmatic activity than the other deposits. No plutonic rocks to which these deposits may be related are known in the region, but the long volcanic history contained in the Tertiary record gives ample evidence of the existence of intrusive rocks of Tertiary age at greater or less depths beneath the surface of large parts of the State.

\section{INTRODUCTION}

\section{OUTLINE OF PROJECT}

In 1929 the State of Oregon made an appropriation for a cooperative survey of the mineral resources of the State, to be carried out jointly by the State mining board and the United States Geological Survey. This bulletin presents the results of an examination, made under this arrangement, of many of the metalliferous deposits east of the Cascade Range. (See pl. 1.) A restudy of the mines of the Sumpter quadrangle was made by D. F. Hewett, of the Geological Survey, and a report on these deposits has appeared elsewhere. ${ }^{1}$ Similarly, the Cornucopia district in the Wallowa Mountains had been examined by the Geological Survey ${ }^{2}$ a short time before this work was undertaken, so that no work was done in either of these areas. Aside from them, however, an attempt was made to cover all the areas in the State east of the Cascade Range in which metalliferous deposits have been worked in recent years and in which the mining developments are accessible. Unfortunately many of the mines whose past production has been large were inaccessible, either altogether or in large part, so that little information could be gained in them. Among these are the Homestead, Bayhorse, and Connor

\footnotetext{
1 Hewett, D. F., Zonal relations of the lodes of the Sumpter quadrangle, Oreg. : Am. Inst. Min. and Met. Eng. preprint, New York meeting, February, 1931.

Ross, C. P., Geology and ore deposits of the southern Wallowa Mountains: U. S. Geol. Survey Bull. - (in preparation).
} 
Creek mines, along the Snake River; the Sanger mine, near Lily White; the Rainbow and Humboldt mines, in the Mormon Basin; and the Virtue mine, in Virtue Flat.

The work was severely handicapped in many districts by the lack of available maps on an adequate scale. For this reason in some of the heavily wooded districts little could be done beyond very local studies in and immediately about the accessible mines.

Field work on the cooperative project was undertaken in 1929. In that year the work was confined chiefly to a study of the copper deposits near Keating, the results of which are presented in another paper. $^{3}$ In 1930 work was resumed early in May and carried on until October 10. The work was carried out in 1929 by James Gilluly and Ralph B. Stewart; in 1930 by James Gilluly, J. C. Reed, C. F. Park, jr., and H. G. Mitchell.

The writers acknowledge with gratitude the hearty cooperation of many mining men in eastern Oregon, especially that of Messrs. J. L. Fisher and William Phalen, of the Mormon Basin; E. McNaughton and George Cullen, of the White Swan mine; Al Borosky, of Medical Springs; C. J. Reuscz, of Durkee; J. L. Layden, of the Flagstaff mine; William Wendt and J. C. Bowen, of Baker; Norman Johnson, Robert Dougherty, B. F. Hurt, and Charles Ray, of Susanville; A. W. Ward, J. C. Howell, G. H. Kight, R. C. Reese, and H. W. Riley, of Prairie City; W. J. Westerling, of Johnson Creek; and Lloyd Wiltsie and C. C. Dunham, of Bear Creek. Mr. Frank C. McColloch, of the State mining board, was very helpful and special acknowledgment is due to him.

\section{GEOGRAPHY}

Northeastern Oregon is largely occupied by a straggling group of mountains to which the name Blue Mountains is somewhat loosely applied. The mountains extend from the vicinity of the Snake River on the east nearly to the Deschutes Valley on the west and include many mountain groups to which other local names have been applied. For instance, the Wallowa Mountains, which lie in the angle between the lower Powder Valley and the Snake River, although somewhat isolated, are usually considered a part of the Blue Mountains, as are the Strawberry Range, south of the East Fork of the John Day River; the Ochoco Mountains, a westward extension of the same uplift which reaches nearly to Prineville; Elkhorn Ridge, west of Baker Valley; and the Greenhorn or Vinegar Mountains, north of the Middle Fork of the John Day.

${ }^{3}$ Gilluly, James, The copper deposits near Keating, Oreg. : U. S. Feol. Survey Bull. 830, pp. 1-32, 1932. 
The individual ranges constituting the Blue Mountains are very irregular. In general, however, they trend roughly east or southeast. In altitude they range from about 4,000 feet to over 9,000 feet. The drainage is exceedingly irregular, although the master streams trend generally parallel with the course of the ranges as a whole. The principal streams are Eagle and Pine Creeks and the Grande Ronde, Wallowa, and Powder Rivers, draining the Wallowa Mountains; the Burnt, Powder, Malheur, Umatilla, and John Day Rivers and Willow Creek, draining Elkhorn Ridge and the Granite, Strawberry, and other ranges; and Ochoco Creek and the Silvies and Crooked Rivers, draining the Ochoco Mountains. All these streams have their waters so largely diverted for irrigation during the summer that their discharge is moderate.

The climate of the area is dry. Baker has an average annual precipitation of about 13 inches; Dayville, in the valley of the South Fork of the John Day River, about 11 inches; and Prineville, in the Crooked River Valley, about 9 inches. Undoubtedly the precipitation on the higher mountains of the region is considerably greater, perhaps four or five times as much.

Throughout the region the lower hills and valleys below an altitude of about 4,000 feet are chiefly barren or clad with sagebrush, rabbitbrush, and grass. Above this altitude the hills are generally clad with pine forests, chiefly with beautiful open groves of yellow pine, although the highest peaks are commonly barren. Along the streams in the higher country willows, alders, and aspen flourish. Although lumbering is a major industry and has been for many years, there still is available a huge supply of timber.

The only standard-gage railroad lines giving access to the Blue Mountains are the Oregon-Washington Railroad \& Navigation Co.'s line between Huntington and Pendleton and the City of Prineville Railway, which joins Prineville with the branch of the Great Northern Railway in the Deschutes Valley. A narrow-gage line, the Sumpter Valley Railway, runs from Baker to Prairie City, and a standard-gage branch of the Oregon-Washington Railroad \& Navigation Co. runs to Medical Springs from the main line at Telocaset and another from Huntington to Homestead, down the Snake River Canyon. However, the region is crossed by a number of excellent highways, notably the Oregon Trail from Huntington to Pendleton, the John Day Highway from Ontario to Fossil and thence to Arlington, and the Ochoco Highway from Redmond to Mitchell.

\section{PREVIOUS WORK}

Although there had been hasty trips by earlier explorers, mainly directed toward collecting fossils in the John Day Basin, the earliest 
systematic investigations of the geology of the region were the reconnaissance of Lindgren ${ }^{4}$ in 1900 in the eastern Blue Mountains and that of Merriam ${ }^{5}$ in 1899 in the John Day Valley. Detailed information may be said to have begun with the two papers just cited. The following list contains the other publications that have added to geologic knowledge of the region. Brief comments have been appended, descriptive of the contents of the several papers.

1901. Lindgren, Waldemar, Rare minerals in gold quartz veins of eastern Oregon: Min. and Sci. Press, vol. 82, p. 252. A mineralogic contribution.

1902. Condon, Thomas, The Two Islands and what came of them, Portland, Oreg. A popular account of the geology of the State, very generalized.

1902. Knowlton, F. H., Fossil flora of the John Day Basin, Oreg.: U. S. Geol. Survey Bull. 204. Almost wholly paleobotanical studies of the collections from the Tertiary of the John Day Basin.

1902. Calkins, F. C., A contribution to the petrography of the John Day Basin, Oreg. : California Univ. Dept. Geology Bull., vol. 3, pp. 109-172. Describes the igneous history as determined from the petrographic character of the sediments and lava flows of the John Day Valley.

1903. Washburne, C. W., Notes on the marine sediments of eastern Oregon: Jour. Geology, vol. 11, pp. 224-229. Gives results of a fossil collecting expedition through the Blue Mountain region.

1903. Merriam, J. C., and Sinclair, W. J., The correlation of the John Day and the Mascall: Jour. Geology, vol. 11, pp, 95-96. An abstract of the correlations suggested.

1907. Merriam, J. C., Tertiary faunas of the John Day region: California Univ. Dept. Geology Bull., vol. 5, pp. 171-205. Vertebrate faunas listed and described.

1909. Pardee, J. T., Faulting and vein structure in the Cracker Creek gold district, Baker County, Oreg.: U. S. Geol. Survey Bull. 380, pp. 85-94. Discusses the relations between faults and veins in the district.

1910. Pardee, J. T., Placer gravels of Sumpter and Granite districts, eastern Oregon: U. S. Geol. Survey Bull. 430, pp. 59-65. Discusses the effect of glaciation on the concentration of the placer gold.

1910. Melzer, E., North Pole mine, Baker County, Oreg. : Eng. and Min. Jour., vol. 89, pp. 868-869. A description of a mine in the Sumpter quadrangle.

1912. Smith, J. P., The occurrence of coral reefs in the Triassic of North America: Am. Jour. Sci., 4th ser., vol. 22, pp. 92-96. Describes the Triassic limestone on Eagle Creek at Martin Bridge.

1912. Parks, H. M., The economic geological resources of Oregon: Oregon State Bur. Mines Bull. 2, Corvallis, Oreg. A summary of the information available at the time.

1914. Pardee, J. T., and Hewett, D. F., Geology and mineral resources of the Sumpter quadrangle, Oreg.: Mineral Resources of Oregon, vol. 1, No. 6, pp. 1-128, Oregon Bur. Mines and Geology. A summary report on several seasons' work in the Sumpter quadrangle.

1914. Grant, U. S., and Cady, G. H., Preliminary report on the general and economic geology of the Baker district of eastern Oregon: Mineral

4 Lindgren Waldemar, The gold belt of the Blue Mountains of Oregon: U. S. Geol. Survey Twenty-second Ann. Rept., pt. 2, pp. 551-776, 1901.

${ }^{5}$ Merriam, J. C., A contribution to the geology of the John Das Basin: California Univ., Dept. Geology Bull., vol. 2, No. 9, pp. 269-314, 1901. 
Resources of Oregon, vol. 1, No. 6, pp. 129-161, Oregon Bur. Mines and Geology. A reconnaissance report on several scattered areas in the Baker quadrangle.

1914. Swartley, A. M., Ore deposits of northeastern Oregon: Mineral Resources of Oregon, vol. 1, No. 8, Oregon Bur. Mines and Geology. Summarizes the available information on the geology of the mines of the area.

1914. Collier, A. J., The geology and mineral resources of the John Day region: Mineral Resources of Oregon, vol. 1, No. 3, Oregon Bur. Mines and Geology. Discusses the stratigraphy, structure, and coal resources of the John Day Basin.

1916. Merriam, J. C., Stock, Chester, and Moody, C. L., An American Pliocene bear: California Univ. Dept. Geology Bull., vol. 10, pp. 87-109. Description of fossils from the Rattlesnake formation.

1916. Merriam, J. C., Mammalian remains from a late Tertiary fornation at Ironside, Oreg. : California Univ. Dept. Geology Bull., vol. 10, pp. 129-135. Describes a Pliocene deposit in the Ironside Mountain quadrangle.

1916. Parks, H. M., and Swartley, A. M., Handbook of the mining industry of Oregon: Mineral Resources of Oregon, vol. 2, No. 4, Oregon Bur. Mines and Geology. An alphabetic list of mining properties throughout the State, with short descriptions of most of the mines and prospects.

1918. Smith, W. D., The Wallowa Mountains, Oreg.: Mazama, vol. 5, pp. 233250. A popular account of a reconnaissance of the Wallowa Mountains.

1919. Smith, W. D., and Packard, E. L., The salient features of the geology of Oregon: Jour. Geology, vol. 27, pp. 79-120. A general account of the geology of the State.

1921. Buwalda, J. P., Oil and gas possibilities of eastern Oregon: Mineral Resources of Oregon, vol. 3, No. 2, Oregon Bur. Mines and Geology. Deals chiefly with the Tertiary deposits.

1921. Pardee, J. T., Deposits of manganese ore in Montana, Utah, Oregon, and Washington: U. S. Geol. Survey Bull. 725, pp. 211-228. Describes deposits near Pleasant Valley and Durkee, in the eastern part of the B]ue Mountains.

1921. Westgate, L. G., Deposits of chromite in eastern Oregon: U. S. Geol. Survey Bull. 725, pp. 37-60. Describes chromite near Canyon City and on Connor Creek.

1921. Packard, E. L., and Nelson, R. N., Geologic occurrence of the Hardgrave Jurassic fauna of Burns, Oreg.: Geol. Soc. America Bull., vol. 32, p. 148. Reports the discovery of a Jurassic locality on the south flank of the Ochoco-Strawberry Mountain uplift.

1922. Stock, Chester, and Furlong, E. L., A marsupial from the John Day Oligocene of Logan Butte, eastern Oregon: California Univ. Dept. Geology Bull., vol. 13, pp. 311-317. Paleontology only.

1923. Chaney, R. W., Paleobotanical contributions to the stratigraphy of central Oregon: Geol. Soc. America Bull., vol. 34, p. 129 (abstract). A summary of results of work on the John Day section.

1924. Chaney, R. W., Fossil floras of the John Day Basin: Carnegie Inst. Washington Year Book, No. 22, pp. 349-350. Paleobotany of the John Day section.

1924. Livingston, D. C., A geologic reconnaissance of the Mineral and Cuddy Mountain mining district, Washington and Adams Counties, Idaho: Idaho Bur. Mines and Geology Pamphlet 13. Contains a geologic map of the Snake River Canyon below Huntington, with a description of the Bay Horse mine. 
1925. Merriam, J. C., Stock, Chester, and Moody, C. L., The Pliocene Rattlesnake formation and fauna of eastern Oregon, with notes on the geology of the Rattlesnake and Mascall deposits : Carnegie Inst. Wash. ington Pub. 347, pp. 43-92. A brief description of the geology and vertebrate paleontology of the upper Tertiary of the John Day region.

1925. Chaney, R. W., A comparative study of the Bridge Creek flora and the modern Redwood forest: The Mascall flora, its distribution and cli. matic relation: Carnegie Inst. Washington Pub. 349, pp. 1-48.

1927. Goodspeed, G. E., jr., Effects of inclusions in small porphyry dikes at Cornucopia, Oreg.: Jour. Geology, vol. 35, pp. 653-662. Discusses petrology of certain dikes at Cornucopia.

1927. Chaney, R. W., Geology and paleontology of the Crooked River Basin with special reference to the Bridge Creek flora: Carnegie Inst. Washington Pub. 346, pp. 45-138. Chiefly paleobotanic data but describes new localities of Tertiary sediments in the Crooked River Basin.

1928. Packard, E. L., A new section of Paleozoic and Mesozoic rocks in central Oregon: Am. Jour. Sci., 5th ser., vol. 15, pp. 22:1-224. Brief description of an important discovery of pre-Tertiary rocks on the south flank of the Ochoco uplift.

1928. Livingston, D. C., Certain topographic features of northeastern Oregon and their relation to faulting: Jour. Geology, vol. 36, pp. 694-708. Discusses the relations between drainage courses and faults in the northeastern part of the Blue Mountain area.

1928. Hewett, D. F., Shannon, E. V., and Gonyer, F. A., Zeolites from Ritter Hot Springs, Grant County; Oreg.: U. S. Nat. Mus. Proc., vol. 73, art. 16. Mineralogic data only.

1928. Buwalda, J. P., Geological features of the John Day region, eastern Oregon: Geol. Soc. America Bull., vol. 39, pp. 269-270. A very brief summary of the stratigraphy and structure of the John Day Basin.

1928. Maxson, J. H., Merychippus isonesus (Cope) from the later Tertiary of the Crooked River Basin, Oreg.: Carnegie Inst. Washington Contr. Paleontology, Pub. 393, pp. 55-58. Describes a Mascall form from a locality near Post, in the Crooked River Valley.

1928. Hodge, F. T., Structural features in John Day and Deschutes River Canyons (abstract) : Pan-Am. Geologist, vol. 49, pp. 305-306. A summary statement of the discovery of new Oretaceous and Tertiary localities west of Mitchell.

1929. Buwalda, J. P., A Neocene erosion surface in central Oregon: Carnegie Inst. Washington Pub. 404 (preprint), pp. 1-10. Describes the relations of a post-Rattlesnake erosion surface, presumably of late Pliocene age, developed in the John Day region.

1929. Goodspeed, G. E., The mode of origin of a reaction porphyry dike at Cornucopia, Oreg.: Jour. Geology, vol. 37, pp. 146-176. The petrology of a porphyry dike at Cornucopia.

1930. Goodspeed, G. E., Recrystallization of xenoliths at Cornucopia, Oreg. : Am. Jour. Sci., 5th ser., vol. 20, pp. 145-150. A petrologic study of inclusions in the intrusive mass at Cornucopia.

1931. Hewett, D. F., Zonal relations of the lodes of the Sumpter quadrangle, Oreg.: Am. Inst. Min. and Met. Eng. preprint of paper for New York meeting. Describes the variations in mineralogy of the different quartz lodes as the intrusion is approached.

A great deal of work bearing on the geology of this region has been done in recent years by Prof. E. L. Packard, of the University 


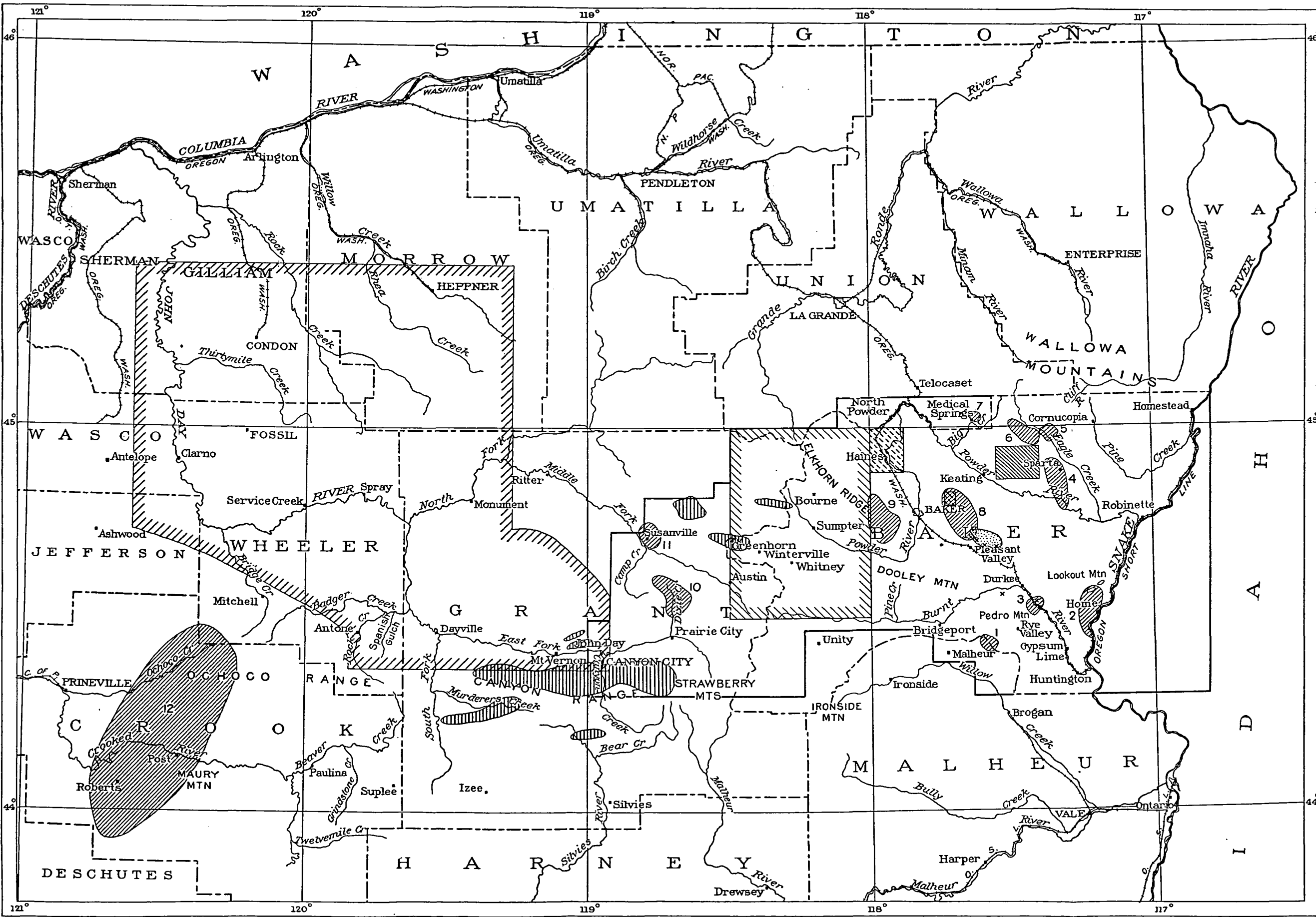

EXPLANATION

OISTR/CTS OESCRIBED IN THIS REPOAT

Mormon Bosin
2 Connor Creek

3 Gold Hill

4 Sparta
5 East Eaglo

Meaical

10 Quartzburg
II Susanville

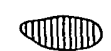

Districts described by Westgate
rus. G.5. Bulletin 725, (1921) 跑

Sumpter quadrangle described
by Pardee and Hewett. MMineral Resources of Oregon, vol. Wo. 6. 19/4)

tescribed by

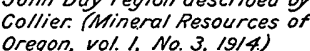

\section{ans}

Ared described by Lindgren,
IV.S. G.S. 22d Ann. Rept,pt.2.1901,

एखि $x$

Manganese deposits described
by Pardea (u. (u. G. Bull. 725. 1921)

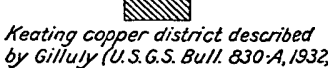

$\mathbb{S}$

Districts mapped by Grant and

oregon, vol, No. $6,1914,4)$

$10 \quad 0$

INDEX MAP SHOWING LOCATION OF MINING DISTRICTS IN EASTERN OREGON 
of Oregon; Prof. J. P. Buwalda, of the California Institute of Technology; Dr. Ralph L. Lupher, of Washington State College; and Clyde P. Ross, of the United States Geological Survey; but unfortunately their results have not yet been published.

\section{GENERAL GEOLOGY}

\section{GENERAL FEATURES}

Tertiary volcanic rocks underlie the surface of most of the region considered in this report. Pre-Tertiary formations are in general exposed only within the straggling structural uplifts that form the Blue Mountains. Extensive exposures of these older rocks are for the most part limited to the more notable uplifts and may be entirely absent in some of the smaller ones. As the general altitude and the structural relief both diminish toward the west, the exposed areas of pre-Tertiary rock diminish in this direction also.

The pre-Tertiary rocks include representatives of all the geologic periods from Carboniferous to Cretaceous, and as some of the more metamorphosed rocks have yielded no fossils, it is possible that earlier periods are also represented.

The known Carboniferous deposits include argillite, chert, and greenstone with subordinate limestone of uncertain age, and a thick series of greenstone, tuff, and limestone of Permian age. Triassic shale, slate, and limestone, Jurassic shale and slate, and Cretaceous conglomerate and sandstone are found in the region. Schist, phyllite, limestone, and greenstone of uncertain age occur along the Burnt River west of Durkee and in the Mormon Basin, but their regional relations are not yet well enough known to decide whether they are Carboniferous or Triassic, as mapped by Lindgren, ${ }^{6}$ or of some other age.

Intrusive rocks of at least two magmatic cycles are widespread in the Blue Mountains, and the stratigraphy, because of the recurrent volcanic activity extending from Carboniferous to Jurassic time, suggests that several cycles may be represented. The older intrusive rocks include gabbro, pyroxenite, dunite, hornblende-quartz diorite, and albite granite and are characterized by a considerable degree of shearing and both cataclastic and metasomatic metamorphism. The age of some of these rocks in the Canyon Range has been fixed as Lower or Middle Triassic ${ }^{7}$; others are known to be post-Triassic. Younger biotite-quartz diorite and granodiorite of post-Triassic, possibly post-Jurassic age are widespread, and the ore deposits of pre-Tertiary age are believed to be genetically related to these rocks.

- Lindgren, Waldemar, op. cit., pl. 64.

${ }^{7}$ Lupher, R. L., personal communication, Apr. 21, 1931.

$164495-33-2$ 
Representatives of the Tertiary period include Eocene volcanic rocks and sediments, Oligocene fluviatile deposits, Miocene basic lavas and fluviatile and lacustrine sediments, and Pliocene tuff and gravel. The Quaternary deposits include glacial moraines in the higher mountains, stream gravel, fan deposits, and volcanic ash.

The structure of the pre-Tertiary rocks is complex. Folds are characteristically close or isoclinal and strike east. The postPermian rocks appear to be less metamorphosed and less strongly deformed than the earlier rocks, and the Jurassic less than the Triassic, though this comparison is less definite. Seemingly more than one epoch of diastrophism is involved-possibly three or four. Exposures of Mesozoic or earlier unconformities are not known in the area with which the writers are acquainted but have been observed in the area studied by Packard south of the Ochoco Range, ${ }^{8}$ and the profound post-Mesozoic unconformity is one of the dominant features of eastern Oregon geology. The Tertiary rocks rest indifferently upon representatives of all the earlier periods in utter disregard of their structure except in so far as pre-Tertiary erosion was guided by it.

The present aspect of the country is dominated by the structure imposed in Tertiary time. Characteristically the structural features trend northwestward in the eastern areas, but in the south and west they trend westward. The mountains stand high chiefly because of uplifts along these lines; the valleys, for the most part, are structural. Movements along these trends have extended to very recent, possibly postglacial time and have been effected by both folding and faulting. Geomorphic interpretation of the topography is difficult, especially in the eastern areas, where these movements are apparently youngest, and deductions as to erosion cycles, either pre-Miocene or later, must be founded upon the recognition of the recency of these displacements.

\section{ROCK UNITS}

\section{CARBONIFEROUS SYSTEM}

Carboniferous rocks are widespread in the Blue Mountain region, being found in the Wallowa Range, ${ }^{9}$ the Snake River Canyon, ${ }^{10}$ Elkhorn Ridge, ${ }^{11}$ near Pleasant Valley, and near Supplee, ${ }^{12}$ south

\footnotetext{
8 Packard, E. L., op. cit., p. 223.

? Ross, C. P., Geology and ore deposits of a part of the Wallowa Mountains, Oreg.: U. S. Geol. Survey Bull. - (in preparation). Washburne, C. W., Notes on the marine sediments of Oregon: Jour. Geology, vol. 11, p. 225, 1903. Gilluly, James, Copper deposits near Keating, Oreg. : U. S. Geol. Survey Bull. 830, pp. 6-13, 1932.

${ }^{10}$ Laney, F. B., personal communication to C. P. Ross.

${ }^{11}$ Lindgren, Waldemar, The gold belt of the Blue Mountains of Oregon: U. S. Geol. Survey Twenty-second Ann. Rept., pt. 2, pp. 577-579, 1901. Pardee, J. T., and Hewett, D. F., Geology and mineral resources of the Sumpter quadrangle: Mineral Resources of Oregon, vol. 1, No. 6, pp. 30-35; Oregon Bur. Mines and Geology, 1914.

${ }^{12}$ Washburne, C. W., op. cit., p. 225. Packard, E. L., A new section of Paleozoic and Mesozoic rocks in central Oregon: Am. Jour. Sci., 5th ser., vol. 15, p. 222, 1928.
} 
of the Ochoco Mountains. Other localities, more doubtfully referable to the Carboniferous, are near Prairie City and Susanville; along the South Fork of the John Day River, on upper Beaver Creek, and on Grindstone and Twelvemile Creeks in the Crooked River drainage basin.

The Carboniferous rocks near Supplee include massive limestone, chert, and chert breccia approximating 3,000 feet in thickness. They are of Mississippian age. ${ }^{13}$ The rocks on Beaver Creek are possibly Devonian ${ }^{14}$ but more likely Carboniferous, and those on Grindstone and Twelvemile Creeks are upper Paleozoic, presumably Carboniferous.

The great section of Carboniferous rocks in Elkhorn Ridge and near Pleasant Valley in the eastern Blue Mountains is composed of siliceous argillite, carbonaceous shale, chert, some interbedded greenstone, and subordinate lenses of limestone. The thickness of a partial section is estimated by Pardee ${ }^{15}$ as about 3,000 feet; possibly it may be much greater. The age of these rocks is not fixed closer than their reference to the Carboniferous, which rests on the determination of Fusulina and some poorly preserved brachiopods collected by Pardee. ${ }^{16}$ Some crinoid stems found near Winterville by Lindgren ${ }^{17}$ and crinoid stems and poorly preserved bryozoans found near Pleasant Valley by the writers suggest but by no means suffice to demonstrate, according to G. H. Girty, that the age of the rocks is Carboniferous.

The rocks in the Wallowa Range referred with some question to the Carboniferous are sandstone, conglomerate, marble, quartzite, slate, and shale, with some volcanic material and much chert, presumably several thousand feet in total thickness. ${ }^{18}$ Their reference to the Carboniferous rests on their close association with a greenstone series, discussed below, which they seem in part to underlie and in part to overlie, and upon their apparent unconformable relation beneath known Triassic rocks.

In the foothills of the Wallowa Range and extending from a point west of North Powder to and beyond the Snake River at Homestead, as well as along the Snake River at the mouth of the Burnt River, there is a thick series of altered volcanic flows and tuffs, minor intrusions, and subordinate interbedded argillite, chert, and lenticulạr limestone. These greenstones are probably for the most part of submarine origin and are composed chiefly of albite-bearing rocks, including keratophyre, quartz keratophyre, albite diabase, and spilite. The thickness is probably at least 3,000 feet. Their age is established as Permian, on the basis of fossil collections from the

18 Packard, E. L., op. cit., p. 222.

14 Wasbburne, C. W., op. cit., p. 226.

${ }_{15}$ Pardee, J. T., op. cit., p. 32.
${ }^{16}$ Idem, p. 35.

${ }^{12}$ Lindgren, Waldemar, op. cit., p. 578.

${ }^{18}$ Ross, C. P., op. cit. 
included limestone near Homestead, ${ }^{19}$ near Medical Springs, ${ }^{20}$ and in the district near Keating. ${ }^{21}$ The rocks along the Snake River at the mouth of the Burnt River have not yielded fossils, and there may be some doubt of their correlation.

The argillite mapped by Lindgren ${ }^{22}$ near Prairie City and the slate of Susanville were referred by him to the Carboniferous on the basis of their lithologic similarity to the Carboniferous of Winterville and Elkhorn Ridge, but this reference must be regarded as tentative in the absence of fossil evidence. The rocks of Susanville in particular seem to differ in lithology rather notably from the known Carboniferous of the region.

\section{TRIASSIC SYSTEM}

Triassic rocks are well developed in the Wallowa Mountains ${ }^{23}$ and are also present in the Snake River Canyon north of Homestead, ${ }^{24}$ in the Canyon Range south of Canyon City, ${ }^{25}$ and in the region of Freeman Creek, the South Fork of the John Day River, and Bear Valley, ${ }^{26}$ in the country between Canyon City and Supplee. Rocks referred with some question to the Triassic occur along the Srake River south of Robinette. ${ }^{27}$

The Triassic rocks of the Wallowa Mountains have been named the Martin Bridge formation. They consist of 1,000 to 3,000 feet of limestone, limy shale, and interbedded volcanic rocks of Upper: Triassic age. ${ }^{28}$ A comparable thickness of chiefly andesitic volcanic rock, exposed in the valley of the Cliff River, is believed by Ross to be contemporaneous with the Martin Bridge formation.

Perhaps 20,000 feet of slate and shale with minor amounts of rhyolite, schistose conglomerate, shaly limestone, greenstone, and massive limestone, are exposed in the Snake River Canyon for about 20 miles along the river from a point near Robinette nearly to the mouth of the Burnt River. These rocks have been referred to the Triassic by Lindgren ${ }^{29}$ and Livingston ${ }^{30}$ but without fossil evidence.

The Triassic rocks north of Homestead are tuff and lava, with interbedded shale and limestone, and carry casts of Halobia or Daon-

${ }^{10}$ Laney, F. B., personal communication to C. P. Ross.

${ }^{20}$ Washburne, C. W., op. cit., p. 225.

${ }^{21}$ Gilluly, James, op. cit., p. 13.

${ }^{23}$ Lindgren, Waldemar, op. cit., p1. 64.

${ }^{23}$ Lindgren, Waldemar, op. cit., pp. 580-582. Ross, C. P., op. cit.

24 Lindgren, Waldemar, op. cit., p. 581.

${ }^{25}$ Lupher, R. L., personal communication to James Gilluly, Apr. 21, 1931.

20 Packard, E. L., op. cit., p. 223.

${ }^{27}$ Livingston, D. C., A geologic reconnaissance of the Mineral and Cuddy Mountain districts, Idaho: Idaho Bur. Mines and Geology Pamphlet 13, pp. 5-6, 1924.

${ }^{2}$ Ross, C. P., op. cit. Smith, J. P., The occurrence of coral reefs in the Triassic of North America: Am. Jour. Sci., 4th ser., vol. 33, pp. 94-95, 1912.

${ }^{29}$ Lindgren, Waldemar, op. cit., pl. 64, pp. 752-753.

${ }^{30}$ Livingston, D. C., op. cit., pp. 5-6. 
ella. ${ }^{31}$ No details as to the thickness or distribution of this formation are known.

The rocks south of Canyon City that have been referred to the Triassic on fossil evidence consist chiefly of dark fine-grained shale, sandstone, grit, and conglomerate. ${ }^{32}$ Their thickness has not been published, but it is known to be considerable.

\section{JURASSIC SYSTEM}

Rocks of Jurassic age have not been proved to be present in the eastern part of the Blue Mountains, although about 3,000 feet of unfossiliferous slate, sandstone, conglomerate, and hornfels (presumably derived from the slate) have been found in the Wallowa Mountains overlying the Upper Triassic and may represent the Jurassic period. $^{33}$

A great thickness of Jurassic shale, impure limestone, sandstone, and conglomerate has been found in the Silvies River country south of John Day. ${ }^{34}$ Jurassic rocks have been reported from the vicinity of Supplee ${ }^{35}$ and from Red Butte, in T. 19 S., R. 30 E. ${ }^{36}$ Unfortunately the results of the large amount of work done in this region by Mr. Lupher have not yet been published, so that more detailed information is not available, beyond the fact that Lower Jurassic fossils like those of the Hardgrave sandstone of California occur in one of the several formations that have been discriminated. The occurrence of the fauna of the Hardgrave sandstone on Beaver Creek, a tributary of the Crooked River, in the Blue Mountains of eastern Oregon, was recorded by Hyatt ${ }^{37}$ on the basis of collections obtained by Thomas Condon.

\section{CRETACEOUS SYSTEM}

Stratified rocks representative of the Cretaceous system have not been recognized in the eastern part of the Blue Mountains but are found along Beaver Creek near Supplee, ${ }^{38}$ near Mitchell, ${ }^{39}$ and in Spanish Gulch east of Mitchell. ${ }^{40}$ The rocks near Mitchell are sandstone, conglomerate, and shale, formerly correlated, on lithologic grounds, with the Knoxville of California. More recent studies by

\footnotetext{
s1 Lindgren, Waldemar, op. cit., p. 581.

Packard, E. L., op. cit., p. 223.

${ }^{83}$ Ross, C. P., op. cit.

${ }^{\text {s4 }}$ Lupher, R. L., personal communication, 1929.

${ }^{35}$ Packard, E. L., op. cit., p. 223.

so Washburn, C. W., op. cit., p. 227.

${ }^{37}$ Hyatt, Alpheus, Trias and Jura in the Western States: Geol. Soc. America Bull., vol. 5 , p. $401,1894$.

${ }^{3 s}$ Packard, E. L., op. cit., pp. 223-224. Washburne, C. W., op. cit., pp. 228-229.

${ }^{30}$ Merriam, J. C., A contribution to the geology of the John Day Basin: California Univ. Dept. Geology Bull., vol. 2, No. 9, p. 284, 1901.

${ }^{40}$ Idem, pp. 284-285. Washburne, C. W., op. cit., p. 228.
} 
Packard ${ }^{41}$ suggest that no beds of Knoxville age are present at Mitchell, but that representatives of both Horsetown and Chico are. They are about 3,000 or 4,000 feet thick.

The Cretaceous rocks exposed at the other localities listed are conglomerate and sandstone of unknown thickness whose fauna suffices to correlate them with the Chico formation of California.

\section{STRATA OF UNKNOWN BUT PRE-TERTIARY AGE}

A considerable thickness of chloritic pencil schist, quartz phyllite, quartzitic schist, greenstone, and limestone occurs on Dooley Mountain, south of Baker, extending west into the southern part of the Sumpter quadrangle and eastward along the Burnt River Canyon to and beyond the Mormon Basin. The series, which is not conspicuous in the Sumpter quadrangle, was there mapped as a part of the Carboniferous argillite, ${ }^{42}$. whereas on Lindgren's map ${ }^{43}$ it was shown as Carboniferous along the Burnt River Canyon west of Durkee but as Triassic in the Mormon Basin. The series seems to be not less than 4,000 feet thick, even after allowance is made for probable isoclinal folding, so that it is a notable element in the geology of the region, but owing to intrusions and Tertiary overlaps, its relations have not yet been deciphered, and, as it has not yielded fossils, it is not known whether the rocks underlie, are equivalent to, or overlie the argillite. The rocks are clearly preTertiary, as they are overlain with marked unconformity by Tertiary sediments and volcanic rocks.

\section{TERTIARY SYSTEM}

The most widespread rocks of the Blue Mountain region are of Tertiary age. Although many years of painstaking work, chiefly by Merriam and his associates, ${ }^{44}$ has resulted in the establishment of a standard section in the John Day Basin, sufficiently detailed work has not yet been done in more easterly areas to enable confident correlations to be made with this section.

\footnotetext{
${ }^{41}$ Packard, E. L., Carnegie Inst. Washington Yearbook, No. 26; p. 365, 1927.

42 Pardee, J. T., and Hewett, D. F., op. cit., map.

${ }^{48}$ Lindgren, Waldemar, op. cit., pl. 64.

4 Merriam, J. C., A contribution to the geology of the John Day Basin : California Univ. Dept. Geology Bull., vol. 2, pp. 269-314, 1901. Merriam, J. C., and Sinclair, W. J., The correlation of the John Day and the Mascall: Jour. Geology, vol. 11, pp. 95-96, 1903. Merriam, J. C., Tertiary fauna of the John Day region: California Univ. Dept. Geology Bull., vol. 5, pp. 171-205, 1907. Merriam, J. C., Stock, Chester, and Mondy, C. L., An American Pliocene bear: California Univ. Dept. Geology Bull., vol. 10, pp. 111-127, 1916. Merriam, J. C., Stock, Chester, and Moody, C. L., The Pliocene Rattlesnake formation and fauna of eastern Oregon, with notes on the geology of the Rattlesnake and Mascall deposits: Carnegie Inst. Washington Pub. 347, pp. 43-92, 1925. Calkins, F. C., A contribution to the petrography of the John Day Basin: California Univ. Dept. Geology Bull., vol. 3, pp. 109-172, 1902. Chaney, R. W., A comparative study of the Bridge Creek flora and the modern redwood forest: The Mascall flora; its distribution and climatic relation: Carnegie Inst. Washington Pub. 349, pp. 1-48, 1925.
} 
The Tertiary section in the John Day Basin includes the Clarno formation at its base, followed by the John Day formation, Columbia River lava, Mascall, and Rattlesnake formations, including representatives of the Eocene, Oligocene, Miocene, and Pliocene epochs.

The Clarno, which is about 2,000 feet thick, ${ }^{45}$ consists of shale, tuff, and andesitic rhyolitic lavas and contains two different floras. Both of these floras were originally referred to the Eocene, ${ }^{46}$. but the upper, whose type locality is Bridge Creek, has been thought to be of Oligocene age, ${ }^{47}$ and Buwalda ${ }^{48}$ has called the entire Clarno "probably Oligocene." In a manuscript submitted in July, 1924, and published in 1926, Knowlton ${ }^{49}$ revised his former opinion and stated that the upper part of the Clarno is probably lower Miocene. Berry ${ }^{50}$ also states that the upper part of the Clarno is clearly younger than Eocene and may well be as young as Miocene. The United States Geological Survey assigns the Clarno to the upper Eocene and lower Oligocene. Beds similar in lithology and flora crop out in the Crooked River Valley ${ }^{51}$ and have been correlated with the type areas on Bridge Creek and near Clarno Ferry, from which the formation extends beyond Fossil to a point near Heppner. ${ }^{52}$

The John Day formation, about 2,000 feet thick, ${ }^{53}$ consists of varicolored shale, tuff, conglomerate, and sandstone, assigned by the United States Geological Survey to the middle and upper Oligocene and lower Miocene, resting conformably on the Clarno. It is exposed in the Crooked River Valley near Post, as well as in the type locality north of the Ochoco Range, in the John Day Valley.

The Columbia River lava, as much as 2,500 feet thick, ${ }^{53}$ rests unconformably on the John Day formation and constitutes the most widespread formation in the State. This lava is thought to extend from the Cascade Range to central Idaho and from central Washington to the Harney Basin in southern Oregon. Some doubt may be expressed as to the detailed correlations through the extremes of this region, but none as to the great extent of this formation within it.

${ }^{45}$ Collier, A. J., The geology and mineral resources of the John Day region: Mineral Resources of Oregon, vol. 1, No. 3, p. 13, Oregon Bur. Mines and Geology, 1914.

to Knowlton. F. H., Fossil flora of the John Day Basin, Oreg. : U. S. Geol. Survey Bull.

204, p. 113, 1902 .

4 Chaney, R. W., op. cit., p. 22.

$₫ 8$ Buwalda, J. P., Geological features of the John Day region, eastern Oregon: Geol. Soc. America Bull., vol. 39, p. 269-270, 1928.

40 Knowlton, F. H., Flora of the Latah formation of Spokane, Wash., and Coeur d'Alene, Idaho: U. S. Geol. Survey Prof. Paper 140, p. 23, 1926.

${ }^{60}$ Berry, E. W., A revision of the flora of the Latah formation: U. S. Geol. Survey Prof.

Paper 154, p. 235, 1929.

bi Chaney, R. W., op cit., p. 21.

sa Collier, A. J., op. cit., geologic map.

sa Idem, p. 10. 
Overlying the Columbia River lava with approximate conformity is the Mascall formation, consisting of tuff and "lake beds" over

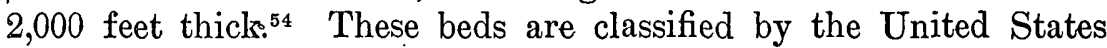
Geological Survey as of middle Miocene age, but they are regarded by some geologists as upper Miocene. They are now preserved only in a syncline at the type locality near Dayville and although formerly more extensive, at least toward the north, ${ }^{55}$ probably did not extend as a continuous formation over much of the country. A flora of similar aspect has been collected from the Payette formation of Idaho, the Ellensburg formation of central Washington, the Latah formation of eastern Washington, Trout Creek in Malheur County, Oreg., and several localities in Nevada and California, as well as from Tipton, a point northeast of Austin, in the Sumpter quadrangle. ${ }^{56}$ The basins in which these deposits were laid down were probably all local, however.

Unconformably overlying the Mascall formation is the Pliocene Rattlesnake formation, consisting of gravel, tuff, and rhyolite 900 feet thick ${ }^{57}$ or less, which was presumably laid down in an old valley of the John Day River. It was a local deposit, without doubt.

In the Sumpter quadrangle ${ }^{58}$ the Tertiary formations recognized differ notably from those exposed in the John Day Valley 50 miles to the west. From bottom to top they are gravel (local only), andesitic tuff breccias (2,000 feet thick), "older basic flows" (100 to 300 feet thick), lake beds and rhyolite, and "younger basic lavas." Of these only the "lake beds" have yielded fossils, which show that they are of Miocene age, presumably correlative with the Mascall. The tentative correlation with the section in the John Day Valley, suggested by Pardee and Hewett, ${ }^{59}$ is as follows:

Sumpter quadrangle

John Day region

Younger basic lavas (?).

Lake beds and rhyolite Mascall formation.

Older basic flows Columbia River lava.

Tuff-breccia John Day formation.

Pre-tuff-breccia gravel Clarno (?) formation.

The difficulties in the way of correlation of these Tertiary beds are considerable, however, as is illustrated in the comparison between

\footnotetext{
${ }_{54}$ Merriam, J. C., Stocl:, Chester, and Moody, C. L., The Pliocene Rattlesnake formation and fauna of eastern Oregon, with notes on the geology of the Rattlesnake and Mascall deposits: Carnegie Inst. Washington Pub. 347, p. 52, 1925.

65 Idem, p. 49.

${ }^{50}$ Chaney, R. W., op. cit., p. 46.

${ }_{\text {57 }}$ Merriam, J. C., Stock, Chester, and Moody, C. L., Carnegie Inst. Washington Pub. 347, p. $56,1925$.

${ }^{68}$ Pardee, J. T., and Hewett, D. F., Geology and mineral resources of the Sumpter quadrangle: Mineral Resources of Oregon, vol. 1, No. 6, pp. 39-47, Oregon Bur. Mines and Geology, 1914.

ต Idem, p. 47 .
} 
the Tertiary section established in the Sumpter quadrangle and that in the Baker quadrangle just to the east. The section in the Baker quadrangle, as determined by the writers, is, from bottom to top, (1) rhyolitic breccia of Dooley Mountain, (2) porphyritic andesite, (3) andesitic tuff-breccia, (4) Columbia River basalt and andesite with interbedded fluviatile and lacustrine beds, (5) lacustrine and fluviatile beds overlying the Columbia River basalt, and (6) basalt. The topmost basalt is local only and occurs just east of the Baker quadrangle, not in it.

The tentative correlation suggested with the Sumpter quadrangle is as follows:

Sumpter quadrangle

Younger basic lavas Basalt.

Baker quadrangle

Lake beds and rhyolite Lake beds.

Columbia River basalt. Columbia River basalt.

Tuff-breccia_-_. $\left\{\begin{array}{l}\text { Andesitic tuff-breccia. } \\ \text { Porphyritic andesite. } \\ \text { Rhyolite breccia of Dooley Mountain. }\end{array}\right.$

Pre-tuff-breccia gravel.

The only fossils collected from the Tertiary rocks of the Baker quadrangle were leaves from the lake beds interfingering with the Columbia River lava in the lower Powder Valley, and these are reported to be of Miocene age, ${ }^{60}$ supporting a tentative correlation with the Mascall on the one hand and the Payette on the other.

The meager extent of many of the Tertiary formations, both sedimentary and volcanic, is so evident from the differences in the rock succession in the John Day Valley and in the Sumpter and Baker quadrangles that the writers hesitate to suggest a correlation with the John Day section in the absence of detailed work in the intervening areas.

\section{QUATERNARY SYSTEM}

Quaternary deposits present in the Blue Mountains include fan gravel and alluvial deposits in Baker and Grande Ronde Valleys and along the main streams and a thin deposit of white volcanic ash, which occurs widespread in the region, especially in alluvial cones at the mouths of mountain streams. A few small glacial moraines deposited by alpine glaciers occur in Elkhorn Ridge and the Wallowa Mountains.

\section{PLUTONIC ROCKS}

General features.-A great variety of intrusive rocks is present in the Blue Mountain region, ranging in composition from serpentine, dunite, pyroxenite, norite, and gabbro through diorite, hornblendequartz diorite, biotite-quartz diorite, and granodiorite to albite

Bo Brown, R. W., personal communication, 1930. 
granite. Structurally the intrusive rocks range from gneissic to almost massive.

Lindgren ${ }^{61}$ suggested that intrusive rocks of more than one age may be present in the region, a conclusion which is supported by the diversity of metamorphism represented in the plutonic rocks, by the long volcanic history recorded in the stratigraphy, and most conclusively by the recent work of $R$. L. Lupher, who has obtained definite stratigraphic evidence in the Canyon Creek area, south of Canyon City, that intrusives of Middle or Lower Triassic age and of probable Upper Jurassic age (post-Callovian, pre-Horsetown) are there present. $^{62}$ In the Sumpter quadrangle a metagabbro sill is involved in folding that is earlier than the intrusion of "granodiorite" at Bald Mountain. ${ }^{63}$

Of the widespread plutonic rocks the granodiorite of Lindgren, here called biotite-quartz diorite, is clearly the youngest and may be tentatively called late Jurassic, correlative with the Idaho batholith. ${ }^{64}$ Petrographic studies by D. F. Hewett show that the Bald Mountain mass of "granodiorite" of Lindgren contains less than 8 per cent of orthoclase, and hence should be classed as quartz diorite. Similarly, studies by the writers show that the so-called granodiorite at Gold Hill, that at Pedro Mountain, and the rock at Haines are typically quartz diorite, only locally carrying enough potash feldspar to warrant calling them granodiorite. The question whether the biotitequartz diorite is merely the last intrusive of a single magmatic cycle or the representative of a cycle distinct from the one which is represented by the gabbro, hornblende-quartz diorite, and associated rocks must be left open, although some evidence that it represents a distinct cycle is available. ${ }^{65}$ Indeed, several distinct cycles may be represented in the other rocks. Evidence to date them accurately is only locally available, however, so that the descriptions here given are based on petrography rather than age.

Serpentine.-Serpentine, largely derived from dunite, pyroxenite, and basic gabbro, occurs in large quantities near Robinsonville and Bonanza, in the Sumpter quadrangle, near Susanville, and in the Strawberry Mountains. ${ }^{60}$ It also occurs in smaller masses in the Mormon Basin, southeast of Rye Valley, on Dooley Mountain (Baker quadrangle), north and northeast of Prairie City, and near Pleasant Valley. In all these localities the serpentine possesses the usual colors, ranging from yellowish green to black, and is thoroughly

\footnotetext{
61 Lindgren, Waldemar, op. cit., p. 596.

os Lupher, R. L., personal communication, Apr. 21, 1931.

${ }^{\text {cs }}$ Pardee, J. T., and Hewett, D. F., op. cit., pp. 34, 36-38.

${ }^{64}$ Ross, C. P., Mesozoic and Tertiary granitic rocks in Idaho: Jour. Geology, vol. 36, pp. $673-693,1928$.

os Reed, J. C., and Gilluly, James, A study of the heavy mineral assemblages of some of the plutonic rocks of eastern Oregon: Am. Mfineralogist, vol. 17, pp. 201-220, 1932.

${ }^{66}$ Lindgren, Naldemar, op. cit., p. 589.
} 
slickensided and sheared. It is soft but tough, very resistant to erosion, and affords a poor soil that is commonly barren of vegetation. Locally asbestos seams are present in the rock, and at least one deposit, near Pine Creek, south of Dooley Mountain, in the Baker quadrangle offers some commercial possibilities.

Other ultrabasic rocks.-Dunite and closely related harzburgite are present in the Mormon Basin and presumably were formerly present elsewhere in the Blue Mountains but are now largely altered to serpentine. Only small bodies of unserpentinized basic rocks remain. Some pyroxenite occurs on Canyon Creek. ${ }^{07}$

Gabbro, diabase, and norite.-Gabbro is widespread in the Blue Mountains, being found in the Wallowa Mountains ${ }^{68}$ in the Virtue district, in Elkhorn Ridge, in the Greenhorn Mountains, near Dixie Butte north of Prairie City, near Canyon City ${ }^{60}$ and in the Mormon Basin. Many of these masses of gabbro show gneissic banding and brecciation, indicating strong compression after their consolidation. The rocks are commonly dark gray and fairly coarse grained and are composed of labradorite or more calcic plagioclase with augite or hornblende derived from augite.

Diabase is found in the Quartzburg district and near Canyon City but is not a common rock among the older intrusives. However, dikes that are considered to be feeders for the Columbia River basalt flows are rather common in the Wallowa Mountains, especially near Cornucopia. ${ }^{70}$ Some of these are diabase, though others are normal basalt.

The only norite so far recorded from this part of Oregon crops out northeast of the Flagstaff mine, north of Virtue Flat, in the Baker quadrangle. It is composed of labradorite and hypersthene.

Diorite.-Diorite is widespread in the Blue Mountain region, in association with the gabbros and also as local facies of the quartz diorites. It has been found in the Mormon Basin, in Elkhorn Ridge, on Dooley Mountain, near Keating, in the Wallowa Mountains, ${ }^{71}$ in the Coyote Hills near Haines ${ }^{72}$ in Dixie Creek Canyon above Prairie City, and in the Powder River Canyon near North Powder.

Commonly the diorites are sheared and recrystallized to some extent, but those associated with quartz diorite are not. The nonquartzose diorites consist of andesine feldspar and augite or hornblende as the essential minerals; some have a little orthoclase and biotite with the usual accessory minerals.

${ }^{07}$ Lupher, R. L., personal communication, Apr. 21, 1931.

es Ross, C. P., Geology and ore deposits of a part of the Wallowa Mountains: U. S. Girol Survey Bull. - (in preparation).

${ }^{\infty}$ Lindgren, Waldemar, op. cit., p. 588.

${ }^{70}$ Idem, p. 593.

71 Ross, C. P., op. cit.

${ }^{79}$ Lindgren, Waldemar, op. cit., p. 588. 
Quartz diorite and granodiorite.-The most widespread granitic rock of the Blue Mountains is biotite-quartz diorite that locally varies to granodiorite. This rock occupies large areas in the Greenhorn Mountains and Elkhorn Ridge and also occurs near Haines, in the Wallowa Mountains, in the Virtue district, and on Lookout and Pedro Mountains. Hornblende-quartz diorite, which differs mineralogically from the biotite-quartz diorite only in containing hornblende rather than biotite as the chief dark mineral, in this region differs also in being commonly somewhat more sheared or even gneissic. It occurs in close association with gabbro near Dixie Butte, north of Prairie City, in the Elkhorn Ridge, near Keating, and in the Virtue district.

Albite granite.-Albite granite is present over considerable areas in the Magpie Peak district, east of Haines, and in the Keating and Sparta districts. It is composed of albite and quartz as essential minerals with usually a little epidote and chlorite and rarely a little amphibole. The rock is characterized by its high degree of brecciation and by peculiar pseudophenocrysts of quartz as well as by a very common graphic structure. It has been regarded as a replacement product of the hornblende-quartz diorite. ${ }^{73}$

\section{STRUCTURE}

Pre-Tertiary structure.-The dominant feature of the structure of the pre-Tertiary rocks of the Blue Mountain country is the prevalent east-west trend of the rocks. The Blue Mountains offer an analogy, in the western part of the Cordillera, to the Owl Creek and Uinta Mountains in the eastern part, in possessing structural features transverse to the strike of the mountain system as a whole. Throughout the nearly 200 miles from the Seven Devils region of Idaho to the Deschutes Valley the principal trends are westward. Exceptions to this trend are noted along the Snake River Canyon between Huntington and Robinette, where the supposed Triassic schist and slates strike north-northeast, and in Elkhorn Ridge, where northwesterly strikes are common.

Through the entire region the bedded rocks lie in closely appressed folds, some of which are probably isoclinal. The metamorphic character of the rocks has thus far prevented the working out of details of structure; presumably more detailed mapping will throw light on the character of the folding and the possibilities of faulting. It seems probable that the territory embraced within the Pine quadrangle is especially critical in this connection.

${ }^{73}$ Gilluly, James, The origin of the albite granite near Sparta, Oreg. : U. S. Geol. Survey Frof. Paper 175, pp. 65-81, 1933. 
The masses of intrusive rocks have clearly influenced the structure and have had a considerable effect in inducing schistosity and local deviations in strike peripheral to them. This feature is especially marked about the Pedro Mountain mass of quartz diorite, whose effects are described on page 36 , and has also been noted in Bald Mountain and McCully Fork, ${ }^{74}$ in the Sumpter quadrangle, although there is some evidence that there has also been permissive intrusion and engulfment of the country rock in this same general region. ${ }^{75}$ Detailed study of the internal structure of the quartz diorite near Haines seems to show that this body was emplaced, in part at least, by shouldering the walls apart.

Nevertheless, inclusions of country rock in several of these intrusive masses have much more marked schistosity than the intrusions, suggesting that at least some of the pressure that induced the schistosity was regional in extent and earlier than the intrusion of the plutonic masses now exposed, hence not directly attributable to them. It is thus possible that the folding and metamorphism of the country rock are primarily results of regional pressure and orogenic activity whose final phases included the injection of the biotitequartz diorite masses. Much more detailed work will be needed to determine these questions.

The fact that the pre-Triassic rocks of the Wallowa Range are clearly much more metamorphosed than the Triassic rocks suggests that at least two periods of orogenic activity have occurred in the region. Another period is indicated by the strong angular unconformity between the Triassic and Jurassic rocks south of Canyon City ${ }^{76}$ and by the fact that some of the pyroxenite of that region is of Lower or Middle Triassic age, whereas a gabbro which intrudes it is probably late Jurassic. ${ }^{77}$ In the mountainous region as a whole, however, sufficient work has not been done to differentiate the effects of these several movements. Provisionally, a post-Permian pre-Upper Triassic and a post-Triassic orogeny may be considered fairly well established.

Pre-Tertiary unconformity.-Wherever the contact is exposed in the Blue Mountain region the Tertiary rocks are seen to rest with marked angular unconformity on the pre-Tertiary rocks. This unconformity is one of the dominant features of the geology of the region. The overlying rocks rest indifferently, at one place or another, upon all the pre-Tertiary rocks, and their attitudes are entirely discordant.

\footnotetext{
74 Pardee, J. T., and Hewett, D. F., op. cit., pp. 86-37.

75 Idem, p. 37.

${ }^{76}$ Lupher, R. L., oral communication, 1929.

${ }^{7}$ Lupher, R. L., personal communication, Apr. 21, 1930.
} 
That the surface upon which the Tertiary rocks were deposited was extremely irregular is demonstrated by both stratigraphic and structural evidence. The stratigraphic evidence may be exemplified by the relations in the valley of the East Fork of the John Day River. At Picture Gorge, northwest of Dayville, the Columbia River basalt is underlain by about 2,000 feet of earlier Tertiary beds, whereas a few miles to the east the basalt rests directly upon the pre-Tertiary basement. Similarly, in the Sumpter quadrangle the "older basic lavas" rest directly on the pre-Tertiary rocks at Black Mountain, whereas only about 10 miles to the south, at King's Mountain, they are separated from the pre-Tertiary by about 1,800 feet of "tuff-breccia." Although an unconformity exists between the John Day and Columbia River lava at Picture Gorge, it is probably not great, and there is apparently complete conformity between the "andesitic tuff-breccia" at King's Mountain and the overlying "older basic lavas." Numerous examples of similar though less striking stratigraphic variations in the Tertiary rocks beneath the Columbia River basalt occur in the Baker quadrangle.

Structural evidence of the irregularity of the surface of unconformity is no less strong. As pointed out by Lindgren, ${ }^{78}$ the Snake River Canyon between the Wallowa Mountains and the Seven Devils exposes an old mountainous topography whose relief exceeds 2,500 feet, abutting against which and finally overtopping its ridges rests undisturbed Columbia River lava. Several exposures near the mouth of Pine Creek show, by the curvature of the columnar jointing of the lava, that.the steep slopes against which the flows abut were in existence at the time of their extravasation and are not due to later faulting. Similar exposures, showing a relief of 300 or 400 feet in a horizontal distance of less than 1,000 feet, are found at the mouth of Big Creek in the Powder River Canyon and along Auhurn Canyon in the Baker quadrangle and on Goose Creek in the Pine quadrangle.

In view of these evidences of great irregularity of the pre-Tertiary surface it has proved thus far impracticable to recognize, in the Blue Mountain region, any representative of the old erosion surface of central Idaho of supposed early Tertiary age. ${ }^{79}$ At any rate, the surface upon which the Columbia River lava was poured out was, even if allowance is made for post-Miocene folding and faulting, by no means a peneplain, or even a surface of low relief.

Tertiary folding and faulting.-Throughout the Blue Mountain region there has been much deformation of the Tertiary rocks, al-

${ }^{78}$ Lindgren, Waldemar, The gold and silver veins of Silver City, De Lamar, and other mining districts in Idaho: U. S. Geol. Survey Twentieth Ann. Rept., pt. 3, pp. 91-93, 1900.

${ }^{79}$ Ross. C. P., Salient features of the geology of south-central Idaho (abstract) : Wash ington Acad. Sci. Jour., vol. 18, pp. 267-268, 1928. 
though the dips impressed upon them only locally exceed $20^{\circ}$ or $30^{\circ}$. The deformation has taken place both by folding and by faulting, but except locally the dominant process has been folding. In the eastern part of the area the folding has occurred chiefly along axes trending northwest or west-northwest, as observed by Pardee and Hewett ${ }^{80}$ in the Sumpter quadrangle and by the writers in the Baker and near-by areas, but in the John Day Valley the axes trend more nearly westward, ${ }^{81}$ and near Heppner southwestward. To a large extent the country owes its present configuration to these folds, the higher country being anticlinal and the lowlands synclinal, although of course the major drainage courses have modified this relationship in many places.

Faulting has occurred along axes that characteristically trend somewhat more northerly than the associated folds, ${ }^{82}$ but the displacement is in gerieral such as to emphasize the structural relief due to the folding. Probably the most noteworthy faults so far mapped are those exposed in the Oregon Copper Co.'s mine on Balm Creek near Keating and those determining the course of Sutton and Alder Creeks southeast of Baker, in the Baker quadrangle. The lastnamed faults continue, at least as a zone, into the line of faults that bound Elkhorn Ridge on the northeast.

The age of the folding is known to be post-Miocene in large part, for fossiliferous upper Miocene beds are involved, but there may have been some folding in earlier Tertiary time. Some folding has also occurred in post-Pliocene time, for the Rattlesnake formation, of this age, is tilted several degrees.

The faults are probably contemporaneous with the folds, but some, such as the one that occurs along the northeast side of Elkhorn Ridge, are probably Pleistocene ${ }^{83}$ or at least their latest activity is of that age, whereas others, such as those in the Lake Creek basin southwest of Baker, and about a mile north of Lost Basin, in the southeastern part of the Baker quadrangle, have been active so recently that the drainage is disrupted by them.

These recent movements have produced further irregularities in the topography of the northeastern part of the Blue Mountains, which already, owing to the contrasted lithology of soft lacustrine Miocene beds and durable cherty argillite, gabbro, and quartzitic schist, was of highly diversified character. It has been impossible

\footnotetext{
${ }^{80}$ Pardee, J. T., and Hewett, D. F., op. cit., pp. 45-47.

${ }^{81}$ Collier, A. J., op. cit., geologic map. Merriam, J. C., Stock, Chester, and Moody, C. L., Carnegie Inst. Washington Pub. 347. pp. 49, 57-58, 1925.

${ }^{82}$ Buwalda, J. P., Report of investigations: Carnegie Inst. Washington Yearbook 27, p. 385, 1928. Pardee, J. T., and Hewett, D. F., op. cit., geologic map. Gilluly, James, Geology of the Baker quadrangle, Oreg.: U. S. Geol. Survey Bull. - (in preparation).

${ }^{83}$ Lindgren, Waldemar, The gold belt of the Blue Mountains of Oregon: U. S. Geol. Survey Twenty-second Ann. Rept., pt. 2, pp. 652-653, 1901.
} 
so far to recognize in this area the Ochoco erosion surface, ${ }^{84}$ of Pliocene age, which is extensively developed in the Ochoco Range and is probably represented in the plateau surface near Condon. Possibly more detailed work over a wider area than was possible for the writers may permit the recognition of this surface, but it seems equally possible that it was not so well developed here as in the internal drainage basin of Harney Valley and the lately aggradational Deschutes Valley.

\section{MINERAL DEPOSITS}

\section{HISTORY OF MINING}

Although mining began in southwestern Oregon about 1852, the discovery of gold in the Blue Mountains dates from the fall of 1861, when a prospector named Griffin located the placer deposits in Griffin Gulch, a few miles southwest of Baker. ${ }^{85}$ The rich placers of Auburn, near by, were discovered the following year, and a rush to the district followed, so that within a year Auburn had a population of 5,000. The evanescence of such placer camps is illustrated by the fact that not a house is standing on the site of this once flourishing city.

The great influx of miners naturally brought about intensive prospecting of the surrounding territory, with the result that within two years practically all the districts of the Blue Mountains and the Boise Basin and Owyhee districts in Idaho were located by prospectors from Auburn. Within a few years the need for increased supplies of water for mining was felt, and considerable investments were made in ditches to carry water to the placer ground. The Auburn Ditch, which is still used to carry the municipal supply of Baker but no longer for mining, was completed in 1863, the Rye Valley Ditch in 1864, the Sparta Ditch in 1873, and the El Dorado Ditch, the longest, in 1873. 'The El Dorado Ditch is over 100 miles long and carried water from a point near the head of the Burnt River to the placer diggings at Malheur. All these ditches except the Auburn have been long since abandoned.

As in most placer districts, the first few years marked the peak of production. Lindgren estimated the output from Oregon during the four years from 1862 to 1865 as probably near $\$ 50,000,000,{ }^{86}$ most of which was derived from the Blue Mountain country. Lindgren's compiled data show that the production fell off rapidly at first,

\footnotetext{
\$4 Buwalda, J. P., A Neocene erosion surface in central Oregon: Carnegie Inst. Wash. ington preprint of Pub. 404, June, 1929.

${ }^{85}$ Lindgren, Waldemar, op. cit., p. 563.

sc Idem, p. 569.
} 
then more slowly until about 1883 , when lode mining began to make itself felt.

Although numerous lode mines were opened before 1870, transportation facilities were so poor that little lode mining could be done until 1885, when the transcontinental railroad now traversing the district was completed. From about 1889 the quartz mines made a rapid increase in production, resulting about 1899 and 1900 in a considerable influx of prospectors and miners, whose influence was felt in a "boom" that led to the development of many mines. The most productive period in the history of lode mining was 1913 to 1918 , but since that period until 1929 , the latest year for which statistics are available, the output has fallen off.

\section{PRODUCTION}

The following table shows the production of gold and silver in the Blue Mountain region since 1903. Statistics for the years 1900 to 1902 are not available by counties. Figures for years up to 1899 are given by Lindgren. ${ }^{87}$

Gold and silver produced in Baker, Grant, and Malheur Counties, Oreg., from 1903 to 1929

[Compiled from annual volumes of Mineral Resources of the United States, published by the United States Geological Survey to 1923, since 1923 by the United States Bureau of Mines. Chapters on Oregon for 1903-1921, by C. G. Yale; for 1922-1926, by J. M. Hill; for 1927-1929, by V. C. Heikes]

\begin{tabular}{|c|c|c|c|c|c|c|c|c|c|c|}
\hline \multirow{2}{*}{ Year } & \multicolumn{3}{|c|}{ Baker } & \multicolumn{3}{|c|}{ Grant } & \multicolumn{3}{|c|}{ Malheur } & \multirow{2}{*}{ Total } \\
\hline & Gold & Silver & Total & Gold & Silver & Total & Gold & Silver & Total & \\
\hline 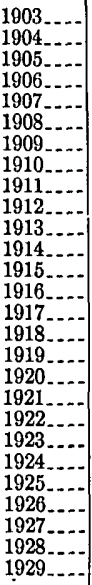 & $\begin{array}{r}\$ 691,546 \\
790,828 \\
771,607 \\
695,653 \\
631,045 \\
507,929 \\
417,538 \\
401,002 \\
389,786 \\
484,041 \\
1,373,480 \\
1,313,967 \\
1,685,382 \\
1,640,626 \\
1,228,199 \\
1,009,656 \\
837,863 \\
890,380 \\
605,465 \\
322,688 \\
290,403 \\
324,252 \\
181,251 \\
75,564 \\
82,305 \\
11,408 \\
25,601\end{array}$ & $\begin{array}{r}\$ 12,520 \\
44,355 \\
55,161 \\
35,984 \\
45,929 \\
9,273 \\
10,147 \\
16,111 \\
16,400 \\
24,071 \\
47,826 \\
32,222 \\
55,833 \\
140,472 \\
82,950 \\
90,385 \\
101,318 \\
83,308 \\
39,509 \\
142,582 \\
69,094 \\
17,809 \\
14,085 \\
5,654 \\
4,800 \\
826 \\
249\end{array}$ & $\begin{array}{r}\$ 704,066 \\
835,183 \\
826,768 \\
731,637 \\
676,974 \\
517,202 \\
427,685 \\
417,113 \\
406,186 \\
508,112 \\
1,421,306 \\
1,346,189 \\
1,741,215 \\
1,781,098 \\
1,311,149 \\
1,100,041 \\
939,181 \\
973,688 \\
644,974 \\
465,270 \\
359,497 \\
342,061 \\
195,336 \\
81,218 \\
87,105 \\
12,234 \\
25,850\end{array}$ & $\begin{array}{r}\$ 102,313 \\
82,280 \\
88,246 \\
55,092 \\
80,645 \\
88,636 \\
41,328 \\
36,201 \\
37,341 \\
21,627 \\
63,652 \\
59,898 \\
6,247 \\
63,593 \\
137,720 \\
101,981 \\
64,495 \\
69,453 \\
108,209 \\
120,268 \\
157,770 \\
171,181 \\
111,607 \\
114,532 \\
152,949 \\
81,862 \\
73,252\end{array}$ & \begin{tabular}{|r|}
$\$ 34,439$ \\
29,417 \\
14,952 \\
2,492 \\
7,106 \\
9,533 \\
881 \\
1,254 \\
1,230 \\
359 \\
55,361 \\
37,911 \\
731 \\
1,052 \\
18,995 \\
13,026 \\
22,021 \\
6,526 \\
1,613 \\
6,671 \\
8,885 \\
7,275 \\
8,008 \\
9,821 \\
20,514 \\
14,935 \\
11,096
\end{tabular} & $\begin{array}{r}\$ 136,752 \\
111,697 \\
103,198 \\
57,584 \\
87,751 \\
98,169 \\
42,209 \\
37,455 \\
38,571 \\
21,986 \\
119,013 \\
97,809 \\
6,978 \\
64,645 \\
156,715 \\
115,007 \\
86,516 \\
75,979 \\
109,822 \\
126,939 \\
166,655 \\
178,456 \\
119,615 \\
124,353 \\
173,463 \\
96,797 \\
84,348\end{array}$ & $\begin{array}{r}\$ 29,227 \\
23,069 \\
18,495 \\
4,847 \\
19,127 \\
14,699 \\
42,353 \\
31,274 \\
14,133 \\
43,430 \\
82,041 \\
50,052 \\
33,639 \\
14,276 \\
1,892 \\
947 \\
1,285 \\
200 \\
3,410 \\
9,536 \\
5,159 \\
8,224 \\
3,336 \\
8,288 \\
1,306 \\
1,076 \\
2,262\end{array}$ & $\begin{array}{r}\$ 10 \\
80 \\
51 \\
87 \\
51 \\
801 \\
850 \\
67 \\
250 \\
2,026 \\
1,260 \\
698 \\
47 \\
270 \\
6 \\
13 \\
2 \\
40 \\
96 \\
53 \\
75 \\
58 \\
214 \\
56 \\
5 \\
11\end{array}$ & $\begin{array}{r}\$ 29,227 \\
23,079 \\
18,575 \\
4,898 \\
19,214 \\
14,750 \\
43,154 \\
32,124 \\
14 ; 200 \\
43,680 \\
84,067 \\
51,312 \\
34,337 \\
14,323 \\
2,162 \\
953 \\
1,298 \\
202 \\
3,450 \\
9,632 \\
5,212 \\
8,299 \\
3,394 \\
8,502 \\
1,362 \\
1,081 \\
2,273\end{array}$ & $\begin{array}{r}\$ 870,045 \\
969,959 \\
948,541 \\
794,119 \\
783,939 \\
630,121 \\
513,048 \\
486,692 \\
458,957 \\
573,778 \\
1,624,386 \\
1,495,310 \\
1,782,530 \\
1,860,066 \\
1,470,026 \\
1,216,001 \\
1,026,995 \\
1,049,869 \\
758,246 \\
601,841 \\
531,364 \\
528,816 \\
318,345 \\
214,073 \\
261,930 \\
110,112 \\
112,471\end{array}$ \\
\hline & $17,679,465$ & $1,198,873$ & $18,878,338$ & $2,292,378$ & 346,104 & $2,638,482$ & 467,583 & 7,177 & 474,700 & $21,991,580$ \\
\hline
\end{tabular}

${ }^{87}$ Lindgren, Traldemar, op. cit., p. 573.

$164495-33-3$ 
The great bulk of the mineral production of the Blue Mountain country has been in gold and silver, but small amounts of copper have been mined in connection with the gold for many years, and between 1915 and 1928 several properties at Homestead, on the Snake River, were operated primarily for their copper. During these years the copper production of Baker County, derived chiefly from the Homestead Iron Dyke mine, amounted to more than $14,000,000$ pounds, valued at about $\$ 2,400,000$. There has also been considerable prospecting for copper and a nominal production from mines near Keating, in the lower Powder Valley. ${ }^{88}$

Considerable chromite was mined during the World War and the years immediately following in Grant County, chiefly from the Strawberry Range and in Baker County from mines near Sumpter and from Connor Creek. These deposits have been described by Westgate. ${ }^{89}$ Under normal conditions the distance from market is such as to preclude the use of ores of the grade here found.

A few flasks of mercury have been produced from the Ochoco Mountains at intervals, at least since 1906, but not until 1929 was there widespread activity in this region. The total production had been small up to the time of this investigation.

Small amounts of manganese were mined near Pleasant Valley and Durkee during 1917, in response to war demands. Like the chromite deposits they are not minable under normal conditions. They have been described by Pardee. ${ }^{00}$

\section{CLASSIFICATION}

The ore deposits other than placers in eastern Oregon may be classified in accordance with the metals they contain or in accordance with their shape and other structural features or their mineralogy. A classification based on the metals contained would list the deposits as gold, gold-silver, copper-gold, quicksilver, chromite, and manganese deposits.

Of these classes, the gold deposits are most widely represented. Gold-silver deposits are few; among the mines described in this report only the Intermountain claims in the Mormon Basin district and the Bay Horse mine on the Snake River fall into this group. Copper-gold deposits, in which the value of the copper exceeds that of the gold, are represented by the prospects in the Keating copper district and by those in the Homestead district on the Snake River,

\footnotetext{
${ }^{88}$ Gilluly, James, Copper deposits near Keating, Oreg. : U. S. Geol. Survey Bull. 830, pp. 1-32, 1932 .

Westgate, L. G., Deposits of chromite in eastern Oregon : U. S. Geol. Survey Bull. 725, pp. 37-60, 1921.

${ }^{90}$ Pardee, J. T., Deposits of manganese ore in Montana, Utah, Oregon, and Washington: U. S. Geol. Survey Bull. 725, pp. 211-228, 1921.
} 
neither of which is included in the present report, and by the Copperopolis property at Quartzburg. Quicksilver deposits are limited to the. western part of the area in the Ochoco country. Chromite deposits, not here described, occur in the Strawberry Range and on Connor Creek, and manganese deposits, all of superficial origin, are present near Durkee and Pleasant Valley.

If the deposits are classified on the basis of structure the predominant mode of occurrence is as fissure veins or replacement veins. This class includes all the deposits primarily valuable for gold, silver, and quicksilver, except possibly that of the Rainbow mine. Stockworks and impregnation zones are represented by all the copper-gold deposits and possibly by the Rainbow mine in the Mormon Basin. Some of the chromite deposits are probably due to segregation; others to impregnation.

Mineralogically the gold deposits are generally simple, carrying a few sulphides, of which pyrite, pyrrhotite, chalcopyrite, galena, sphalerite, and arsenopyrite are by far the most prominent, in a gangue of quartz, ankerite, calcite, and locally sericite, chlorite, serpentine, scheelite, fuchsite, barite, and clay. Metallic minerals present locally but nowhere abundantly include magnetite, hematite, tennantite, tetrahedrite, cobaltite, enargite, glaucodot, bornite, covellite, chalcocite, bismuthinite, polybasite, native gold, native bismuth, and hessite.

Most of the copper deposits carry chalcopyrite, pyrite, galena, sphalerite, and arsenopyrite in a quartz-barite gangue with some chlorite and epidote, but the Copperopolis deposit carries considerable tourmaline as the principal associate of quartz in the gangue.

The quicksilver deposits are composed of cinnabar and pyrite in a gangue of quartz, chalcedony, opal, chlorite, nontronite, calcite, dolomite, several clays, and asphalt.

\section{MAGMATIC RELATIONSHIPS OF THE MINERAL DEPOSITS}

The mineral deposits, considered genetically, appear to fall into three groups, each related to a different suite of igneous rocks. Two of these groups, including the chromite and most of the gold deposits, are of pre-Tertiary age. The third, including the quicksilver and at least one gold deposit, is of middle or late Tertiary age.

The chromite deposits, as is the rule elsewhere, are all directly associated with ultrabasic rocks-dunites and pyroxenites-which have been thought to represent the earliest of the pre-Tertiary magmatic cycles.

By far the most of the gold deposits are situated in close juxtaposition with bodies of biotite-quartz diorite, and all investigators 
have agreed in assigning these deposits to an origin in the final exudations from these plutonic bodies. According to the interpretation offered in this report, these deposits are thus related to the latest pre-Tertiary intrusive cycle, or, if only one pre-Tertiary cycle should prove to be represented in the region, to the latest intrusions of that cycle.

The reference to a source in the biotite-quartz diorite is most strongly supported by the marked increase in the value, size, and persistence of the veins near the larger bodies of the rock, such as those in the western Elkhorn Ridge and at the east end of the Greenhorn Mountains, in the Sumpter quadrangle. Most of the larger mines have been developed within the masses of biotite-quartz diorite, or not more than 2 or 3 miles from the contact. The concentration of the larger mines near these intrusive rocks is emphasized by the parallel concentration of the more intensely mineralized areas whose deposits have not so far been productive in a large way. These, too, cluster about the masses of biotite-quartz diorite in a very suggestive manner.

The quicksilver deposits of the Ochoco region and at least one gold deposit, the Ophir-Mayflower, are contained in Tertiary rocks and hence are obviously related to much younger magmatic activity than the other deposits. It is likely that the deposit of the Oregon King mine, near Ashwood, is of the same age, but no work was done on this deposit during this survey. No plutonic rocks to which these deposits may be related are known to be exposed in the region, but the long volcanic history contained in the Tertiary record gives ample evidence of the existence of intrusive rocks of Tertiary age at greater or less depths beneath the surface of large parts of the State.

Mineralization connected with Tertiary intrusive rocks has been widespread in the Cascade Mountains, 30 or 40 miles west of this region, and in Idaho but has been very slight in eastern Oregon, compared with the mineralization associated with the older intrusions. The difference in age between the two series of deposits is emphasized by the presence of detrital gold derived from the older veins in the oldest Tertiary sediments, proving that these deposits, not formed at shallow depths, had been deeply weathered and eroded before the Tertiary deposition began.

Mineralogic contrasts between the Tertiary quicksilver deposits and the pre-Tertiary precious-metal deposits are profound, the one group being characterized by cinnabar, calcite, opal, chalcedony, and clay, the other by pyrite, arsenopyrite, chalcopyrite, sphalerite, galena, tetrahedrite, quartz, ankerite, and mica. The only Tertiary gold deposit here described, that of the Ophir-Mayflower mine, has 
no arsenic minerals and has much chalcedony and montmorillonite, an association which is commonly regarded as indicative of lower temperature during deposition than that characteristic of the preTertiary deposits.

\section{GENERAL ECONOIIIC CONSIDERATIONS}

The mines in eastern Oregon that have hitherto been most productive lie mainly in the Sumpter quadrangle and in the Wallowa Mountains. Neither of these districts is here described. The mines considered in this report have been for the most part small, and those that had been more productive in the past were inactive at the time of this survey. Aside from some of the quicksilver properties, none of the mines were producing at the time of this examination, although development work was in progress at several.

The notable and widespread production of placer gold in the region, however, sufficiently demonstrates the presence of mineral deposits over very large areas in the Blue Mountains, and the question arises why the mining industry should be dormant. The reason is largely economic but is fundamentally geologic. The principal economic factors have been the prohibitive costs of mining, milling, and transportation. These costs were abnormally high from 1915 to 1929 , and although they have since substantially decreased they are still materially higher than in the pre-war years. Production in many gold camps throughout the country declined abruptly during this period, and according to the figures on page 25 the small production in Malheur County reacted similarly. That from the larger mines declined less abruptly, and the closing of most of the mines in Sumpter, the leading district, reflected the inability to continue operations at a profit. A contributing factor in depressing the industry was the difficulty in successfully treating the complex sulphide ores in the Sumpter district. ${ }^{01}$

As regards geologic conditions, one of the most severe handicaps of the districts here described arises from the structure-that is, there are few large persistent veins. Instead of the valuable minerals being concentrated in a regular vein system, most of the deposits are characterized by irregular, commonly interrupted, and intersecting veinlets, narrow and difficult to follow. Thus an amount of gold which, if it occurred in a single vein, would be adequate to support a mine is scattered throughout a large body of gangue from which it can not at present be economically recovered. Eastern Oregon in this respect resembles large parts of Alaska and certain areas in Idaho and Montana, from which huge sums

${ }^{\text {o1 }}$ Pardee, J. T., and Hewett., D. F., op. cit., p. 34. 
have been won by placer mining without the discovery of correspondingly concentrated lode deposits. A few large veins have been found, however, and perhaps others remain to be developed. Examples of the larger veins are the Connor Creek, Rainbow, Sanger, Virtue, and Flagstaff.

Lindgren has emphasized the similarity between the geology of eastern Oregon and that of the Mother Lode belt of California and has stated ${ }^{92}$ that the ore may be expected to extend "to the greatest depths yet attained in gold mining." This statement is doubtless correct in the sense that the mineralization persists to such depths. To the writers, however, it appears likely that very few of the veins will be found so persistent as this statement might imply, because only a few of them have demonstrated lengths that may be commensurate with persistence to great depths. The mineralogy of the veins may and doubtless does persist to great depths, but whether many of the veins will prove structurally continuous and minable in depth is doubtful. Exceptions must be made for the long veins of the Sumpter quadrangle and possibly for some of the larger veins here described, but on the whole it is likely that few of the veins can be followed with fair hope of successful mining below a few hundred feet.

These comments should not be understood as condemning the entire region, even though mining costs continue to be relatively high. Several of the mines here described seem capable of profitable exploitation if their development is undertaken in a conservative way and with a minimum of overhead. Other deposits, such as those at Quartzburg and Susanville, although promising intrinsically, are so remote from transportation that they must probably await new developments in the technique of recovery or lower costs before they can operate profitably on any considerable scale. Even in these districts, however, pocket hunting on a small scale may prove profitable.

Another factor entering into the question of profitable exploitation involves the mineralogic changes that may be expected as the veins are followed downward. In this connection it seems likely that the primary mineralization may be assumed to be of about constant character, for although it is possible that a zoning may occur, the changes involved will probably not affect the recovery in any one mine. More significant than primary changes are the mineralogic changes due to weathering. As far as was detected in this survey of the region there has been no supergene enrichment of gold below the oxidized zone. There has been, however, a residual enrichment in the weathered zone, where valueless gangue has been leached out, leaving the free gold in higher concentration. Below

92 Lindgren, Waldemar, op. cit., p. 610. 
the water level the veins become of lower grade, because there has been no such removal of the gangue, but, what is of more consequence, instead of being free and readily amenable to amalgamation, the gold is so thoroughly locked up in sulphides that only a small part of it is recoverable by amalgamation, and the ore does not lend itself readily to cyanidation. Concentrates must be brought to very high values before they can be profitably shipped to smelters, because of the high cost of transportation from many of the districts.

The quicksilver deposits near Prineville have a distinct advantage in this respect, because their product is compact and can readily be transported. Several of the prospects appear to have good possibilities for profit if worked in a conservative way and with adequate condensing apparatus on their retorts.

\section{THE DISTRICTS}

\section{MORMON BASIN}

\section{GEOGRAPHY}

The Mormon Basin district lies in T. 13 S., R. 42 E., Willamette base and meridian. The boundary between Baker and Malheur Counties passes through the district. The Mormon Basin, the valley which has given its name to the district, is an oval depression about 3 by 2 miles in extent, formed by the headwaters of Basin Creek, a tributary of Willow Creek. Altitudes in the basin range from about 4,500 feet to about 6,000 feet. The climate is dry, with moderate snowfall, which rarely interferes seriously with travel.

The district is reached by a wagon road about 12 miles long from Brogan, the railhead on Willow Creek of a branch line connecting with the Oregon Short Line at Ontario, but most of the travel to and from the district goes by way of Durkee or Huntington, 22 and 25 miles, respectively, distant by road.

\section{FIELD WORIK}

No base map of the area was available, so that it was necessary to make the accompanying topographic map (pl. 2) concurrently with the geologic map. An approximate elevation obtained by aneroids was used for an initial point, a base line measured by stadia, and the map developed by triangulation and stadia. The topographic sketching is the work of C. F. Park, jr. About two weeks was spent in the district.

\section{GEOLOGY}

\section{GENERAL FEATURES}

The dominant and also the oldest geologic formation of the district is composed of quartzite, quartz schist, slate, greenstone, and chlorite schist with a few small limestone lenses of unknown age. 
Lindgren ${ }^{93}$ referred them with some doubt to the Triassic, but in the absence of fossil evidence their lithology does not appear so convincingly like that of the known Triassic of the Wallowa Mountains as to justify any confident correlation with these rocks.

Intrusive into these rocks are many basic and ultrabasic igneous rocks, now represented for the most part by greenstone, serpentine, amphibolite, and talc rocks, highly sheared and deformed to a degree comparable to that of the accompanying schist, although locally masses of gabbro, pyroxenite, dunite, and harzburgite are still recognizable as such.

Along the north edge of the mapped area is the large quartz diorite mass of Pedro Mountain, and apophyses of this mass occur in bosses and sills elsewhere in the basin. Several aplite and pegmatite dikes, presumably related to this intrusive mass, were also observed. These rocks have not undergone the intense shearing to which the previously described rocks have been subjected. Lindgren's map shows another "granite" area just southwest of the basin, but the mapping of this report did not extend so far. No evidence bearing on the age of these intrusions has been obtained in this survey, and there is apparently no reason to question the post-Jurassic and pre-Chico age assigned to them by Lindgren.

The lower part of the basin is largely occupied by stream gravel and sand, with boulder deposits of Tertiary age. These deposits contain interbedded dacite flows and are capped by andesite. Their former extent was considerably greater, as is shown by remnants on the divide at the head of California Gulch. The present streams are actively removing these old gravel deposits from the basin.

The schist is steeply folded, with the schistosity (which is for the most part parallel to the bedding) striking roughly parallel to the periphery of the quartz diorite of Pedro Mountain, or about N. $45^{\circ}-80^{\circ}$ E. in the eastern part of the area and N. $25^{\circ}-70^{\circ} \mathrm{W}$. in the western part. Dips are chiefly steep toward the north, but locally a few southward dips were observed. The Tertiary rocks, which are strongly discordant with the schists, are tilted at moderate angles, the steepest observed dip being $18^{\circ}$.

\section{SCHIST SERIES}

The schist series in the district is composed chiefly of metamorphosed sediments. The dominant rock of the series is quartz-mica schist, with both muscovite and biotite developed along the shear surfaces. Locally there are masses of nonschistose quartzite, possibly similar to the original rock from which the schist was derived or representing less shaly, hence less readily altered interbeds in the sediments.

${ }^{93}$ Lindgren, Waldemar, op. cit., pl. 64. 


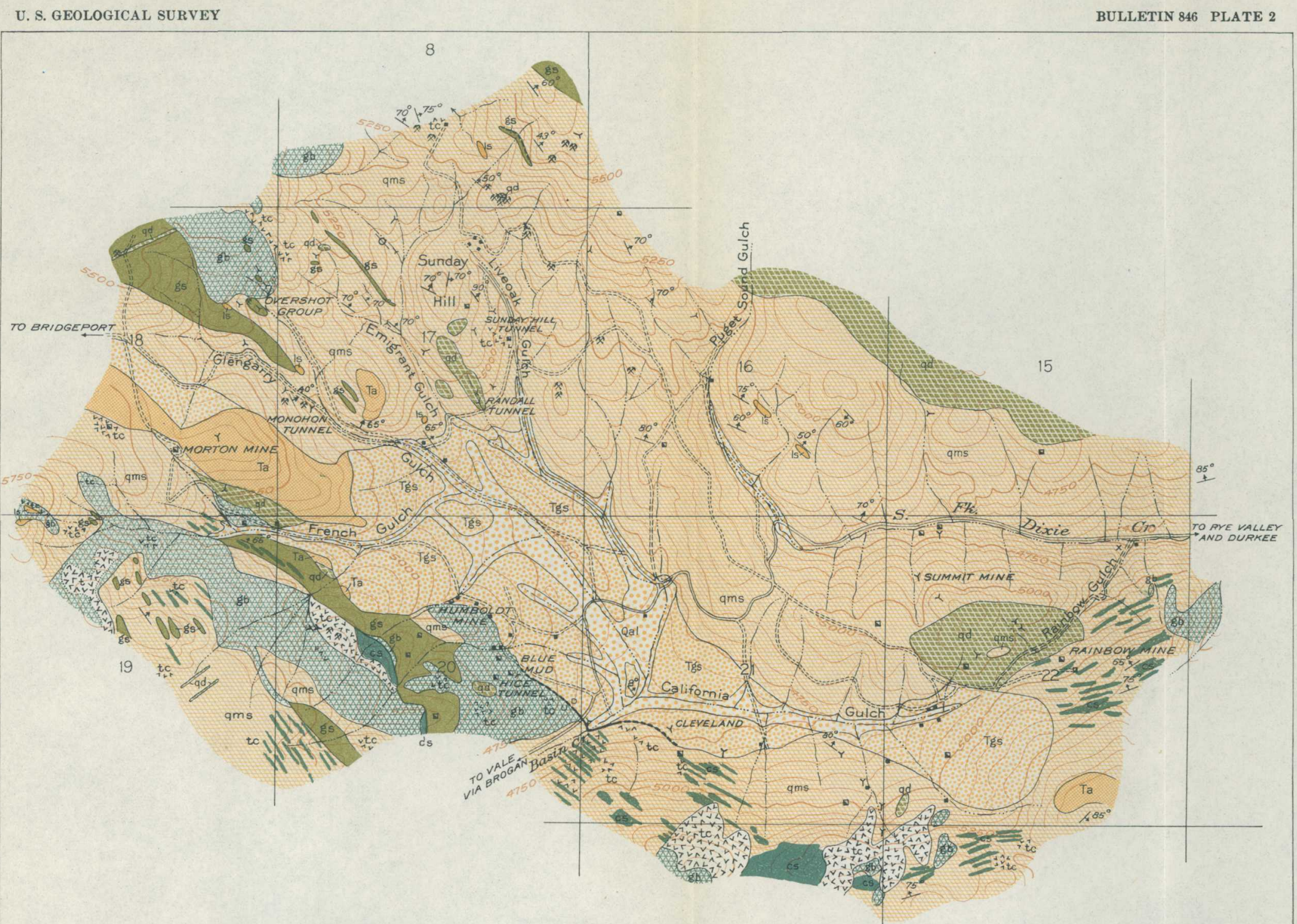

EXPLANATION

$\therefore$ Qa!

Alluvium

UNCONFORMITY

Andesite

Tgs

Gravel, sand, and silt UNCONFORMITY

सम+1)

Quartz diorite and
related rocks

cravist

Tale rock, with some

.

Gabbro and related bas

gs

Greenstone

(Mostly altered sills and lave
with some plutonic rocks)

C'

Chlorite schist (chiefly altered lavas and pyro-
clastic rocks)

$$
\mathrm{qms}^{\mathrm{Is}}
$$

Quartz-mica schist,
slate, and quartzit (some limestone lenses, Is)

Fault -

Fault
(U, upthrow; D, downthrow)

Strike and dip of rocks

Strike of vertical rock

Mine

Shaft

Tuńne1 
Along the divide southeast of California Gulch there is a considerable belt of black carbonaceous slate interbedded in the schist series. Similar slate also occurs north of the Rainbow mine. Elsewhere in the basin similar slate and, locally, carbonaceous phyllite are intercalated in the schist series, but these rocks, doubtless because of their weakness, are ordinarily poorly exposed. They may be much more widespread than appears from the sparse outcrops. In places these rocks are altered to andalusite hornfels.

Half a dozen or more limestone lenses were observed in the schist series. All are small, none being more than 300 or 400 feet long and 75 feet wide and most of them much smaller. These lenses were carefully searched for fossils but without success. Most of them are coarsely crystalline carbonaceous limestone with a little quartz, but one or two show some alteration to diopside and tremolite hornfels.

In the southern half of the mapped area there are large tracts in which chlorite schist is the dominant rock. It conforms in structure with the associated quartz-mica schist and slate. Locally these rocks are associated with recognizable igneous rocks, and they are accordingly interpreted as the sheared and metamorphosed equivalents of these andesitic or diabasic rocks. Some pyroclastic rocks are also represented. Their mineralogy, as revealed by the microscope, is in accordance with such an origin, for the dominant minerals are chlorite, serpentine, actinolite, and talc, with .subordinate bronzite and biotite. The less sheared altered igneous rocks shown as greenstone on Plate 1, of which the largest area occurs on the ridge between Emigrant and Glengarry Gulches, appear to be altered andesites or possibly diabases. They have both brown and green amphiboles, feldspars ranging from labradorite to andesine in composition, and much titanite and magnetite.

\section{BASIC INTRUSIVE ROCKS}

Basic and ultrabasic intrusive masses, chiefly of moderate dimensions, are distributed around much of the southern periphery of the basin. The largest body is that on the hillside south of French Gulch, but a considerable mass occurs at the head of Emigrant Gulch, a smaller one near the Humboldt mine, and a great many smaller bodies on the ridge south of California Gulch.

The rocks composing all these bodies are highly sheared and have clearly undergone substantially as severe metamorphism as the surrounding schists. The shearing is reflected in the mineral composition of the rocks. The gabbro mass forming the hill between Emigrant and Glengarry Gulches, in the NE. $1 / 4$ sec. 18, is saussuritized and albitized. A few relict feldspars can be recognized as labradorite, but most have gone over to albite-zoisite aggregates or even unmixed albite. Hornblende, pleochroic in green and brown, is the 
dominant dark mineral in the less altered specimens, but tremolite, actinolite, and talc replace it in the more altered rocks.

The larger mass south of French Gulch is of more basic character, and but few specimens carry recognizable feldspars or their derivatives. Tremolite, talc, serpentine, and bronzite are the chief minerals present, although a little diallage and brown hornblende remain in some specimens. Where feldspar occurs it is labradorite. This rock mass seems to pass by gradation into the more sheared bodies shown on the map as greenstone and is believed to be the parent rock from which the greenstone was derived. The unmetamorphosed facies was probably a pyroxenite.

On the upper slopes of the hills south of California Gulch are several altered basic intrusive bodies. Some appear to be sheared dunite, having been originally composed almost wholly of olivine, of which a few relicts remain in rocks now made up chiefly of talc, serpentine, actinolite, and chlorite. Porphyroblasts of bronzite, in part altered to serpentine, are common in these rocks. The large bodies of talc schist associated with these ultrabasic intrusive bodies are doubtless derived from them, and the irregular interpolations of talc rocks in the dominant chlorite schists of the hillside down to California Gulch may represent metamorphosed sills of related rocks.

A small body of ultrabasic rock occurs on the ridge 2,000 feet northeast of the Rainbow mine. It is a sheared harzburgite, composed chiefly of olivine and enstatite, which are partly altered to talc, tremolite, chlorite, and serpentine. Much titanite and magnetite also occur. Along the borders this mass is altered to hornblende schist.

A great many small masses of talc schist, tremolite-anthophyllitetalc rock, and amphibolite are intercalated in the quartz-mica schist and chlorite schist of the area. These rocks probably represent metamorphosed basic sills or plugs related to the gabbro and ultrabasic masses just described.

\section{QUARTZ DIORITE AND RELATED ROCKS}

The economically most important intrusive rock of the Mormon Basin is rather basic quartz diorite. The large mass of Pedro Mountain, about 6 miles in diameter, borders the mapped area on the northeast, and the smaller bodies distributed through the rest of the basin are probably apophyses of this mass. Though some of these rocks show crushing, their alteration is negligible compared with that of the more basic rocks. Some show a mild mineral parallelism near their contacts.

The Pedro Mountain body is composed of rather light-colored coarse-grained granitic rock. In composition it is a calcic quartz 
diorite; its plagioclase, which is strongly zoned, ranges from $\mathbf{A n}_{60}$ to $\mathrm{An}_{45}$ in composition. Both biotite and hornblende occur in large splendent crystals. Quartz is plentiful, but orthoclase is negligible in amount, if present at all.

Many of the smaller intrusive masses, such as the mass just west of the Rainbow mine and some of the dikes in the Rainbow mine, to judge from specimens on the dump, are really quartz gabbro if classified rigorously on the basis of their feldspars, which are labradorite. Other masses are true quartz diorites, however, with oligoclase or andesine feldspars. Among these rocks are the small mass at the Hice tunnel and the dominantly sill-like intrusions in Sunday Hill. A few dikes of quartz diorite porphyry occur, with some albitic aplites and, in the Pedro Mountain mass, a few pegmatites.

\section{TERTIARY ROCKS (MIOCENE?)}

A belt of poorly consolidated gravel and sand of Tertiary age extends across the basin from a point just south of the Rainbow mine to the head of Glengarry Gulch. Remnants of these gravel deposits and associated hillside wash too slight to mask the bedrock and hence not shown on Plate 2, are found over much of the more gently sloping part of the rest of the basin, even on the ridge between California Gulch and Puget Sound Gulch, proving a much wider extent in the past. Indeed, these remnants are in many places so thick that the bedrock is locally concealed, although on the accompanying map only continuous areas are shown. Owing to the softness of the gravel it forms gently rolling topography.

This Tertiary gravel rests on a dissected surface developed upon the steeply tilted schist series and its intruding quartz diorite and basic rocks, a surface of profound unconformity. The gravel that makes up the lower part of the formation is commonly clearly derived from the adjacent hillsides, being dominantly made up of quartz schist, gabbro, or chlorite schist, according to the neighboring bedrock. Toward the upper part of the formation bedding and sorting are clearly seen and the rocks no longer show the close relationship to the near-by bedrock. A few thin dacite flows are interbedded in the formation, and it is capped by andesite flows. Locally these andesite flows overlap the transported material and rest directly upon only slightly reworked Tertiary soil.

The formation, exclusive of the capping andesite, attains a thickness between 300 and 400 feet; the overlying andesite is nearly 200 feet thick in places.

No fossils were obtained from these beds, so that their age must be determined on other, less precise grounds. The association with the volcanic rocks and the unconsolidated nature of the deposits 
combine to render a Tertiary age practically certain. The rocks may be Miocene or Pliocene; the fact that all the fossil plants found in similar rocks in the Baker quadrangle are of Miocene age somewhat favors the reference to the Miocene, although in this area of local basins there is no certainty that they may not be younger.

\section{QUATERNARY ROCKS}

The only Quaternary rocks of the area are the hillside talus deposits and the gravel along the present streams. Most of this gravel is derived from the Tertiary deposits by reworking, although of course there is some contribution from the bedrock series.

\section{STRUCTURE}

The structural discordance between the Tertiary and pre-Tertiary rocks is profound; it is doubtful if they have any structural similarities beyond that given by the structural control of erosion in the pre-Tertiary rocks, which has governed, in part, the areas of deposition of the Tertiary rocks.

The pre-Tertiary rocks enter the area on the east with strikes of $\mathrm{N} .45^{\circ}-80^{\circ} \mathrm{E}$. Toward the west the strikes swing first to eastward trends and then to $\mathrm{N} .70^{\circ} \mathrm{W} ., \mathrm{N} .50^{\circ} \mathrm{W}$, and finally about $\mathrm{N}$. $25^{\circ}-35^{\circ} \mathrm{W}$. on the west edge of the mapped area. Unfortunately the area mapped is not large enough to show the relations of these rocks to the quartz diorite mass of Pedro Mountain. If it were, it could be clearly seen that these changes in strike reflect the curvature of the outline of that intrusive body. This parallelism of the strikes of the country rock with the intrusive contact of the quartz diorite of Pedro Mountain is seen farther northwest and north, in the southeast corner of the Baker quadrangle, and is known to extend about three sides of the Pedro Mountain mass. Although the central part of the Pedro Mountain mass is nearly or quite free from directional features, near the borders the rock shows a strong mineral parallelism, locally approaching a gneissic character. Because of this internal structure and the evident profound effect on trends of the inclosing rock, the Pedro Mountain body is believed to have had a notable part in the metamorphism of the pre-Tertiary rocks. Nevertheless, inclusions in the mass have schistosity fully developed, as if the batholith had invaded an already metamorphosed series.

The schistosity of the pre-Tertiary rocks only locally dips at angles flatter than $60^{\circ}$; dips of $80^{\circ}$ are much more common. With very few exceptions the dips are toward the north, so that the rocks of the Mormon Basin seem to dip under the edge of the Pedro Mountain intrusion. Stretching in the rocks, where determinable, is very steep in the plane of schistosity, pointing to the same relation. 
The Tertiary rocks have been only slightly deformed, except along the fault that bounds their outcrop on the south at the head of Basin Creek Canyon. Here they have been reduced to gouge along a narrow zone, close to which dips as high as $18^{\circ}$ have been imposed on them. Other faults doubtless occur in the Tertiary rocks, but none could be traced for any considerable distance. From observa. tions in near-by areas it is known that Tertiary and even Quaternary faulting is general throughout this part of eastern Oregon and probably has occurred here in some places wholly within the preTertiary rocks as well as cutting the Tertiary.

\section{ORE DEPOSITS}

The ore deposits of the Mormon Basin include quartz lodes, veins, and replacement masses of irregular shape. They occur in all the pre-Tertiary rocks, especially in or near the quartz diorite masses. The minerals were probably introduced in emanations from the Pedro Mountain intrusion of quartz diorite and its smaller satellites.

The veins consist of quartz, with ankerite and fuchsite as the chief gangue minerals and carry as metallic minerals pyrite, arsenopyrite, galena, sphalerite, polybasite, hessite, and tetrahedrite. Of these, pyrite and arsenopyrite are by far the most plentiful. About 45 per cent of the gold is free-milling, according to the experience of the Rainbow mine. ${ }^{94}$ Figures for the other mines are not available.

The veins are irregular, both in trend and thickness. So few are known that it is probably premature to generalize, but there seems to be a rough tendency for the veins to follow the strike of the inclosing rocks, or to cut it at a narrow angle. Thus the Cleveland and Rainbow veins strike N. $60^{\circ}-75^{\circ} \mathrm{E}$., the Humboldt about east, and the Randall N. $60^{\circ}-70^{\circ} \mathrm{W}$., whereas the Phalen vein in the Sunday Mill mine strikes N. $40^{\circ} \mathrm{W}$. These trends are roughly parallel to the border of the intrusive body of Pedro Mountain, but this parallelism is not so marked as to serve as a guide to prospecting. The divergent strike (N. $5^{\circ}$ E.) of one of the veins in the Randall mine gives cause for caution in this regard.

THE MINES

RAINBOW

Location.-The Rainbow mine is just north of the divide between California Gulch and a southern tributary of the south fork of Dixie Creek, locally known as Rainbow Gulch.

${ }^{04}$ Swartley, A. M., Ore deposits of northeastern Oregon : Mineral Resources of Oregon, rol. 1, p. 224, Oregon Bur. Mines and Geology, 1914. 
History and production.-The deposit of the Rainbow mine was discovered about 1901, and the Commercial Mining Co. was organized to develop it. By 1907 the mine was a large producer, with a mill of 19 stamps. The capacity of the mill and concentrator was 50 tons a day in 1909. In 1911 no ore was raised, although development work went forward, and a fair production was made from cyaniding tailings. In 1911 the mine was sold under option to the United States Smelting, Refining \& Mining Co., of Boston, Mass. This company operated the mine for 32 months until December, 1915 , when, by failing to take up the option, it permitted the mine to revert to the original company. ${ }^{95}$ In 1916 the mine had a 400 foot shaft, a 1,500-foot adit, and 3,700 feet of drifts and crosscuts. A 100-ton mill and cyanide plant was on the property. A 100-foot winze was sunk from the 400 -foot level. ${ }^{96}$ In 1918 the mine was closed and dismantled. A small production was made in 1922 and again in 1925 from dump rock worked in a 10-ton mill. In 1926 the mine was sold to the present owners, the Rainbow \& Sunday Hill Mining Co.

The production prior to 1911 was $\$ 242,000$. The United States Smelting, Refining \& Mining Co. produced $\$ 1,083,360$ from 95,747 tons of ore, saving $\$ 11.40$ a ton from $\$ 12$ mill heads. During 1913 to 1915 the mine was the largest producer in the State, but the production since December, 1915, has been small.

The mine buildings and shaft timbers have been destroyed by fire, and many of the old stopes have caved to the surface, so that the mine was entirely inaccessible at the time of this survey.

Geology.-The geology of the Rainbow mine has been described by Swartley ${ }^{97}$ as follows:

The geology of the Rainbow mine is comparatively simple; the country rocks are chiefly slate with some granitic intrusives on the hanging-wall side and some limestones and greenstones on the footwall side. The greenstone [shown on pl. 2 as gabbro and related ultrabasic rock] is an intensely altered rock with an excessive development of secondary hornblende; its original character is hard to make out.

The vein fissure has a strike of $\mathrm{N} .60^{\circ} \mathrm{E}$. and in the upper levels a dip of $66^{\circ} \mathrm{N}$., while in the lower levels a dip of $54^{\circ} \mathrm{N}$. Before the period of vein formation the fissure was filled with a porphyry dike [not mapped on pl. 2] locally known as the "spotted dike." *** This rock is a porphyry genetically related to an intrusive magma that is probably a basic granodiorite or quartz diorite or perhaps even a diorite in composition. **** The Rainbow vein is not of the fissure type but of the brecciated vein type. The fractured zone varies from a few feet in width in some places to over 50 feet in

${ }^{85}$ Parks, H. M., and Swartley, A. M., Handbook of the mining industry of Oregon: Mineral Resources of Oregon, vol. 2, No. 4, p. 66, Oregon Bur. Mines and Geology, 1916.

Oe Yale, C. G., Gold, silver, copper, lead, and zinc in Oregon: U. S. Geol. Survey Mineral Resources, 1916, pt. 1, p. 264, 1919.

${ }^{07}$ Swartley, A. M., Ore deposits of northeastern Oregon : Mineral Resources of Oregon, vol. 1, pp. 222-224, Oregon Bur. Mines and Geology, 1914. 
others. It is made up of fragments of country rock cemented by quartz. The porphyry dike is included in the brecciated zone to a large extent. On both walls of the lode there is a quartz vein. The footwall of the lode is the best developed and has been most worked. The vein quartz is fine grained and contains but a very small amount of arsenopyrite and pyrite in which there is some gold. Some of the free gold in the vein is large enough to be distinctly visible, but for the most part it can not be seen. A small amount of actinolite and a little chlorite occur with the quartz, and when these minerals are present the gold values are said to be greater. This is noteworthy as it points toward the precipitating action of the ferromagnesian silicates.

There has been some movement since ore deposition, as is shown by the gouge and slickensides. The quartz, however, is not fractured to any great extent.

The genesis of this vein is simple, that of ascending solutions from the underlying magma. The presence of the porphyry dike shows that the vein fissure followed this line of weakness.

The mine is worked through a shaft about 500 feet deep, but most of the development has been done on the 200 level, where the vein has been drifted upon for 1,700 feet. Mine and mill are operated by electricity with power furnished by the Idaho-Oregon Light \& Power Co.

\section{SUNDAY HILL}

Location and development.-The Sunday Hill mine is on Sunday Hill, near the west side of the Mormon Basin, southwest of the head of Live Oak Gulch. It is owned by the Rainbow \& Sunday Hill Consolidated Mining Co. J. L. Fisher was manager at the time of the survey.

The mine is opened by an adit on the 200 level and by a vertical shaft, 75 feet deep, from which a short level, called the 100 level, is turned. This level is connected by an incline with the main or 200 level, which is 79 feet below, a total of 154 feet below the collar of the shaft. The accessible workings consist, in addition to the shaft and connecting raises, of 110 feet on the 100 level, 31 feet on an intermediate 150 level, and about 1,625 feet on the 200 level. A 50 -foot raise and a 30-foot winze have been driven from the 200 level. Other than this winze, which is full of water, no work has been done below the 200 level.

The development work on the property has been done, in 1920 and following years, chiefly by W. C. Phalen, the discoverer of the vein. But little work has been done by the present owners. In 1922 a 5-ton amalgamating mill was built and test runs made. In 1923 the mine was equipped with electric power, and in 1929 about 560 tons of $\$ 10$ gold ore was mined and treated. Development work proceeded in 1925, but water level was reached, and the base ore found was not amenable to treatment in the available mill, so no production was made. A small output was made in 1926, however. ${ }^{98}$

\footnotetext{
${ }^{28}$ Mineral Resources of the United States, 1922-1926.
} 


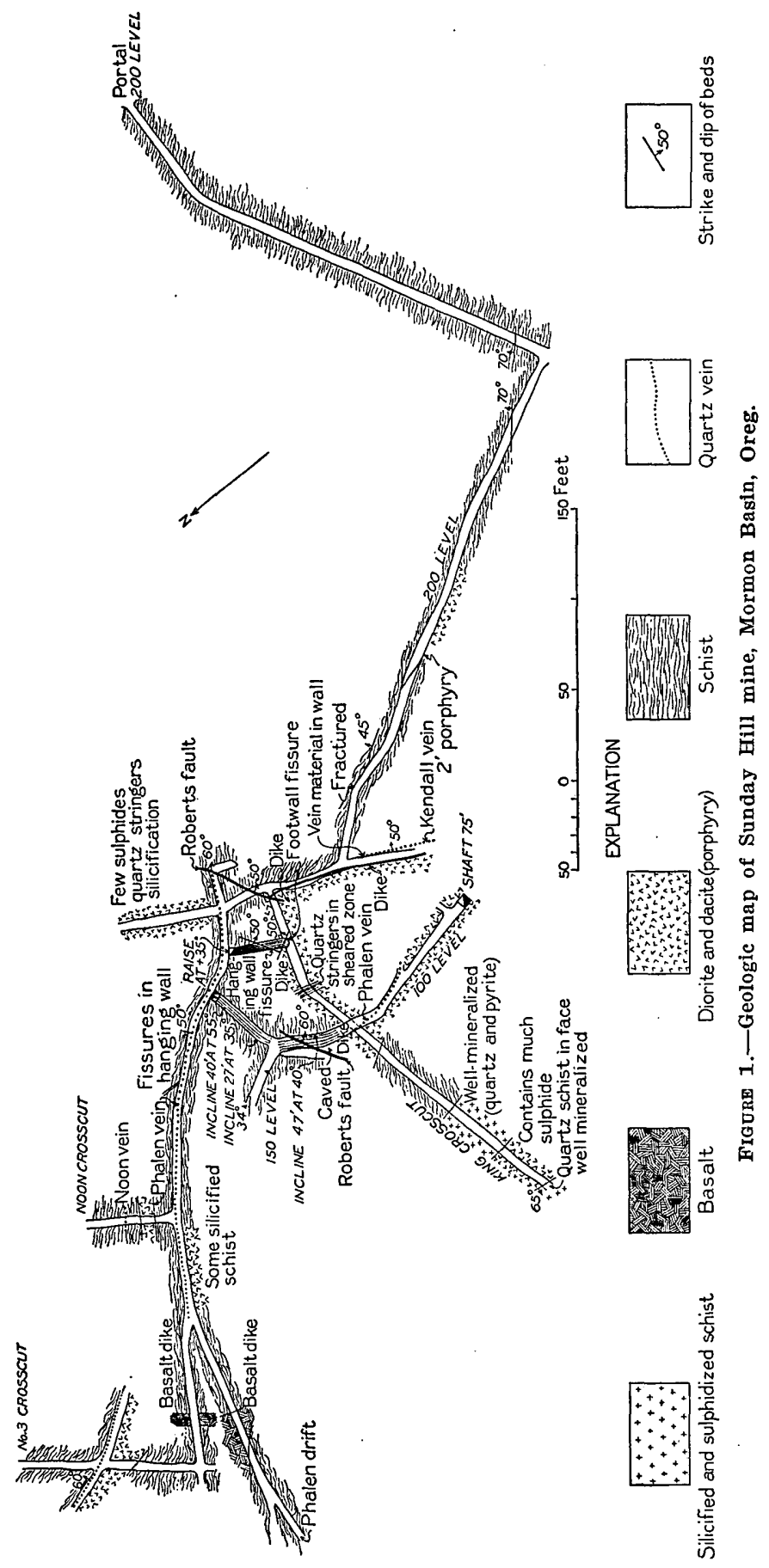


Geology.-The country rock consists of quartz-mica schist, striking N. $30^{\circ}-70^{\circ} \mathrm{W}$. and dipping $45^{\circ}-70^{\circ} \mathrm{N}$. Numerous dikes of quartz diorite and related rocks are present in the mine, and a few basaltic dikes occur. (See fig. 1.)

Quartz stringers are numerous, and one strong vein, the Phalen, has been opened for 230 feet. On the east, the Phalen vein, which strikes N. $40^{\circ}-50^{\circ} \mathrm{W}$. and dips $50^{\circ} \mathrm{N}$., is cut off on the 200 level by a normal fault, called the Roberts fault, striking N. $50^{\circ}-60^{\circ} \mathrm{E}$. and dipping $50^{\circ}-60^{\circ} \mathrm{SE}$. This fault is also exposed on the 150 level and in the incline between the 150 and 100 levels. On the 100 level the downthrown segment of the Phalen vein has been followed for about 60 feet from the Roberts fault. The segment of the Phalen vein in the footwall of the Roberts fault on the 200 level ranges from a few inches to 5 feet in thickness but finally pinches out on the west into a few minor quartz stringers and some gouge. The vein is accompanied by gouge almost throughout its length, especially on the hanging wall. The quartz itself is considerably brecciated. In the area regarded as minable the vein averages about $2 \frac{1 / 2}{2}$ feet thick.

The Noon vein consists of about 3 inches to 1 foot of quartz and gouge. It appears to be a hanging-wall fissure branching from the Phalen vein. Where exposed, it is near or along the contact of quartz-mica schist and a dike of fine-grained diorite. A few other veins, the Kendall and the King especially, have been exposed, but very little work has been done on them. In several places, especially in the King crosscut, the country rock, both schist and diorite, has been intensely silicified and impregnated. with pyrite. It is reported to carry gold, averaging between $\$ 10$ and $\$ 11$ a ton.

The vein material consists chiefly of quartz and gouge. Some ankerite is present and considerable green mica, which is locally called roscoelite but actually is fuchsite, as determined by W. T. Schaller. Some sericite also occurs. Pyrite is the commonest sulphide, but arsenopyrite, galena, and sphalerite are also present. Galena is regarded as a sign of especial richness in gold. Some of the gold occurs free from visible sulphides and is free-milling.

The ore is very spotty in tenor. According to the assay map of the company there are considerable areas of ore averaging more than $\$ 10$ to the ton in gold. Some individual samples run above $\$ 50$ to the ton.

\section{RANDAIL}

The Randall tunnel is at the south end of Sunday Hill, in the northwestern part of the Mormon Basin. It was under the management of William Phalen at the time of the survey. Little but assessment work was being done. No production has been recorded. 
There are about 1,200 feet of workings. Two tunnels have been driven, the upper one 24 feet above the lower, and a quartz vein has been drifted on for about 300 feet on the lower level.

The mine is in quartz diorite and schist, as shown on Figure 2. The quartz diorite is part of a body about 1,500 feet long, which, though locally crosscutting, is of a general sill-like shape.

Two quartz veins are penetrated by the lower adit, one at 245 feet from the portal and the other near the face. The first strikes about N. $60^{\circ} \mathrm{W}$. and dips about $32^{\circ} \mathrm{SW}$. and has been drifted on for 100 feet east of the tunnel. It has also been followed westward for nearly 175

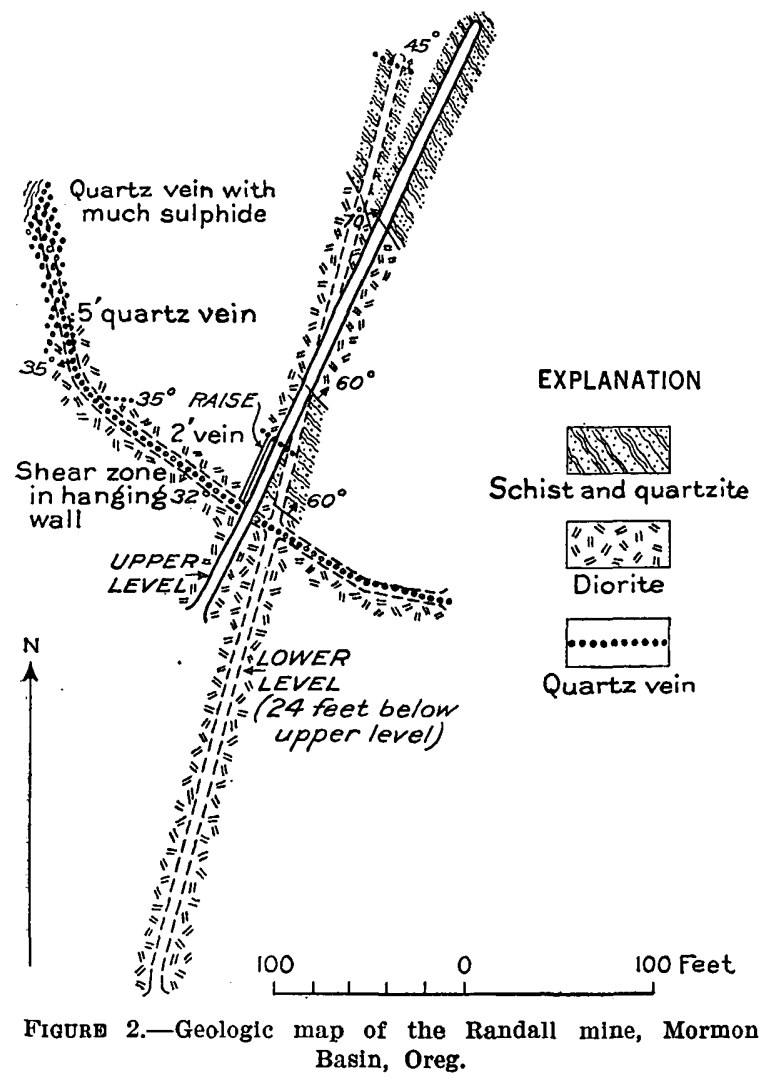

feet, curving slightly northward. At this point it is intersected by a much larger vein, which strikes nearly north, perhaps a little east of north, and dips about $35^{\circ} \mathrm{E}$. This northward-trending vein has been obliquely penetrated by the drift for about 50 feet. It is fully 8 feet thick, but no wall is exposed at the face. The footwall, poorly exposed, seems to be schist.

The northwestward-trending vein ranges from somewhat less than 2 feet to over 5 feet in thickness. It has a hanging wall of sericitic 
gouge, apparently a fault. Several small southeastward-trending footwall branches occur along this vein. None are over 6 inches thick, and they are apparently not persistent.

A second northwestward-trending vein is penetrated by the lower adit near the face. This vein is much thinner, being only about 6 inches thick at the floor of the tunnel, and has not been found on the upper tunnel level. It strikes N. $70^{\circ} \mathrm{W}$. and dips $45^{\circ} \mathrm{NE}$.

The first northwestward-trending vein is also narrow on the upper level, and only about 10 feet of drifting has been done on it. The northward-trending vein has not been cut on this level nor in any of the several surface cuts, most of which are too far east to intersect it if the vein has a constant attitude.

The veins consist largely of quartz, with some ankerite, fuchsite, and sericite. Small amounts of sulphides, chiefly pyrite and arsenopyrite with smaller amounts of hessite, galena, and sphalerite are present. Much of the gold is free, as all the workings are in the oxidation zone. Oxidation products include cerusite and jarosite.

The assays, reported by Mr. Phalen, show from from $\$ 10$ to $\$ 15$ a ton in free gold, with some gold also in the sulphides.

Further drifting on the wide vein at the face of the west drift on the lower tunnel is contemplated.

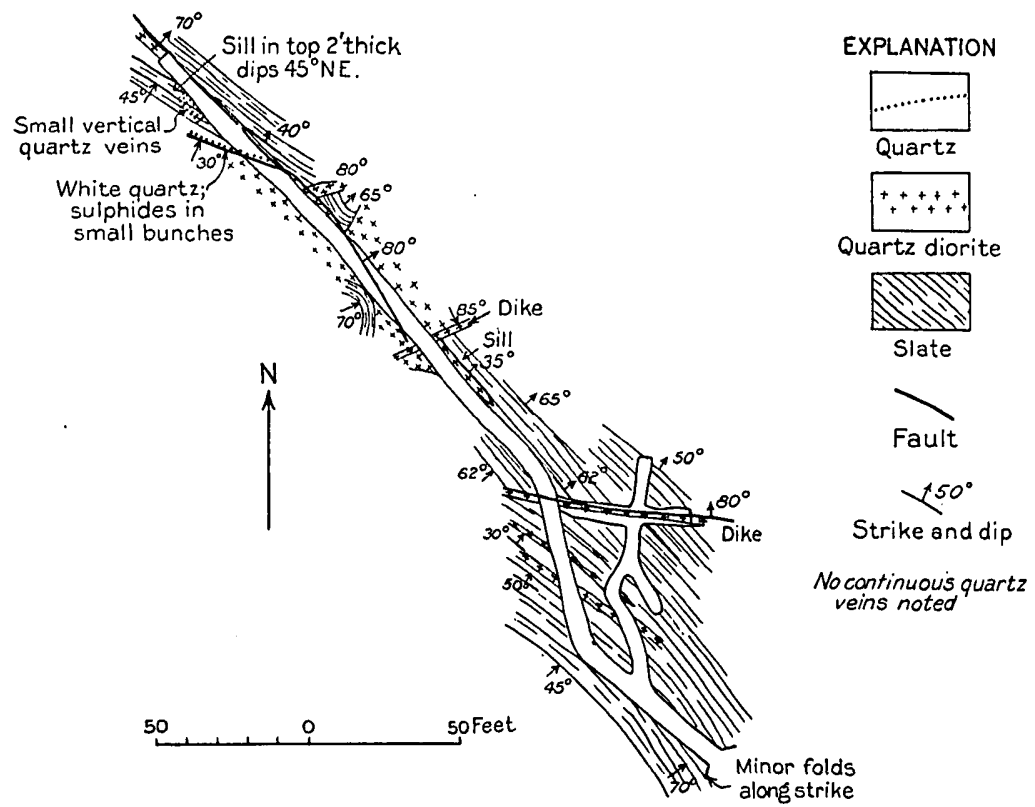

Fiaure 3.-Geology of tunnel on Orershot group, Mormon Basin, Oreg.

OVERSHOT

The Overshot group of claims, owned by Charles McNamara, are near the head of the north fork of Glengarry Gulch. Tunnels aggre- 


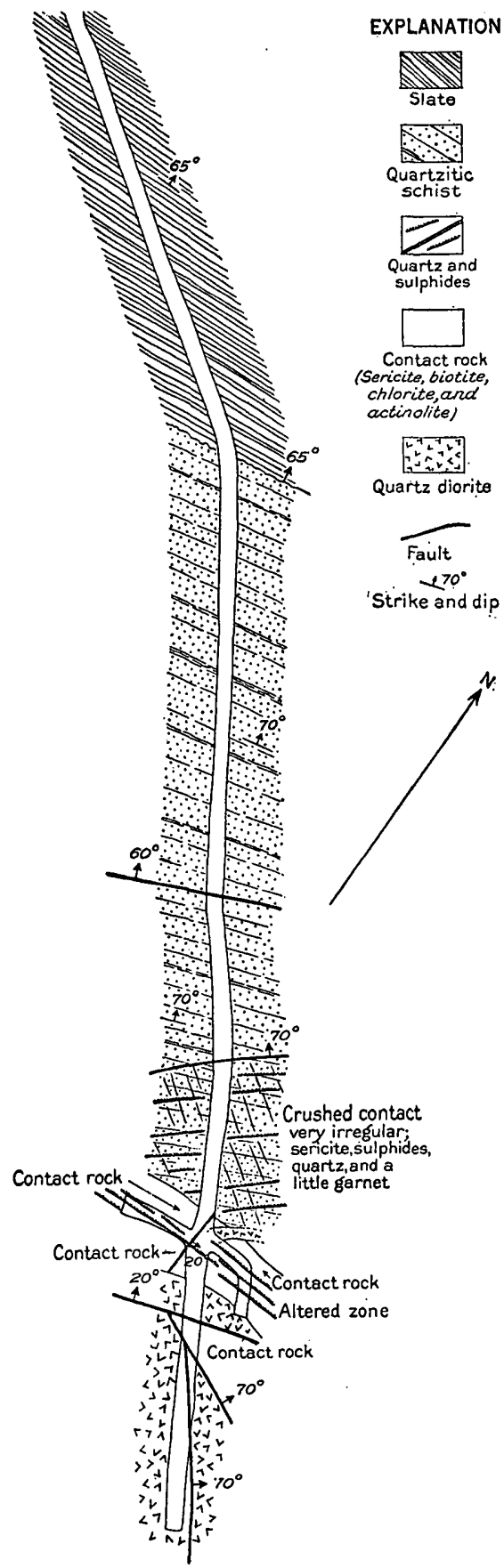

50 50 150 FEET

Figure 4.-Geology of the Summit Mining \& Milling Co.'s tunnel, Mormon Basin, Oreg. gating a few hundred feet have been driven, the longest about 300 feet in length. (See fig. 3.)

The country rock is chiefly slate and quartz-mica schist striking about $\mathrm{N} .45^{\circ} \mathrm{W}$. and dipping s tee ply northeastward. The schist and slate have been intruded, for the most part concordantly, by small sheets and sills of altered quartz diorite, with a few dikes-all too small to be shown on Plate 2.

No veins are cut by the workings. A few very thin quartz-filled fissures are present, but these are small and discontinuous. According to Mr. McNamara, the gold is found in the altered diorite or near its contact with the schists. No production has been reported.

\section{SUMMIT}

The Summit mine, owned by the Summit Mining \& Milling Co., Charles Miller, manager, is on the hillside south of the South Fork of Dixie Creek, west of Rainbow Gulch.

Several tunnels have been driven. The largest, 1,400 feet long, driven back of the old mill near the creek level, was caved and inaccessible at the time of this survey, but the next higher and longest accessible tunnel (see fig. 4) contained about 750 feet of workings. 
The tunnel is in slate and schist for about 500 feet from the portal and then penetrates the quartz diorite mass that crops out on top of the hill. Some intersecting faults have brought an additional segment of altered country rock within the diorite. Near and within the quartz diorite intrusion the quartz-mica schist is considerably altered and carries garnet, biotite, chlorite, actinolite, and sericite, with local masses of quartz and sulphides. Some small fissures, trending nearly parallel with the contact and close to it, carry some quartz and sulphides and have been drifted on for a few feet.

Although some production has been reported from this mine in 1914 and 1915, when a 5-stamp amalgamating mill was operated, there has been none in recent years.

\section{HUMBOLDT}

The Humboldt mine is in the southwestern part of the basin. The mine, which had been idle for 15 years at the time of this survey, was full of water, badly caved, and inaccessible. It was operated for several years prior to 1916 by the Oregon-Idaho Investment Co. In 1909 it was the most productive mine in the district. In 1910 it had a 200-foot vertical shaft, 2,000 feet of tunnels, and a 10-stamp mill. Electric power was brought to the property in 1912 , and 20 stamps were dropping in 1914, but in 1916 it was closed down. In 1930 the property was owned by R. L. Gorman. No definite figures could be obtained on the production of the mine, but it is known to have been moderate.

The mine has been described by Swartley ${ }^{00}$ as follows:

Formerly the mine had four levels and was worked by means of a vertical shaft. Recently the shaft has been sunk 100 feet deeper and a crosscut driven to the vein, upon which drifting has been started.

There is a 20-stamp mill upon the property in which recovery is by amalgamation and concentration with Wilfleys and vanners. A considerable percentage of the gold is free milling. The concentrates are shipped to smelters, but it is proposed to install a cyanide plant to treat the tailings.

The many movements that have taken place in this immediate vicinity have caused the geology to be confusing. The chief country rock is slate with diorite porphyry in the footwall. In the upper levels trachyte is said to form a large part of the hanging wall. This trachyte was probably a feeder to some of the recent acidic lava flows. ${ }^{1}$

The lode has an east-west strike and a dip of $75^{\circ} \mathrm{N}$. in the upper levels but with a steeper dip below. In some places the lode is as much as 40 feet wide, but the actual quartz veins are rarely more than a few feet thick.

\footnotetext{
${ }^{00}$ Swartley, A. M., op. cit., pp. 224-227.

1 The only rocks that crop out close to the mine are Tertiary gravel and Mesozoic (?) metagabbro, so that it is probable that the "slate," probably chlorite schist of Plate 2, is covered by the Tertiary rocks. The diorite porphyry is probably a dike and could not be found on the surface.-J. G.
} 
The chief gangue mineral is quartz, and much of it is in a sugary condition, due to crushing by later movements. Some calcite is present in the vein. The ore, especially in the upper levels, is free gold, and many fine specimens have been taken from the mine. In the lower levels more sulphides are to be found. They are chiefly arsenopyrite, pyrite, galena, and sphalerite. The galena and sphalerite are said to contain high values in gold.

The Humboldt lode is situated in a zone of weakness, where fracturing and movement have taken place many times. The first break allowed the injection of the diorite porphyry that is found on the footwall. Then came the fracturing that made the opportunity for the hot ascending silica solutions to deposit their burden of quartz and metallic sulphides. Movement took place during the period of vein formation, as is evidenced by the recementing of broken quartz fragments. Considerable postmineral movement has taken place, as is shown by the sugary quartz, the gouge, and the actual faulting of the vein in the lode.

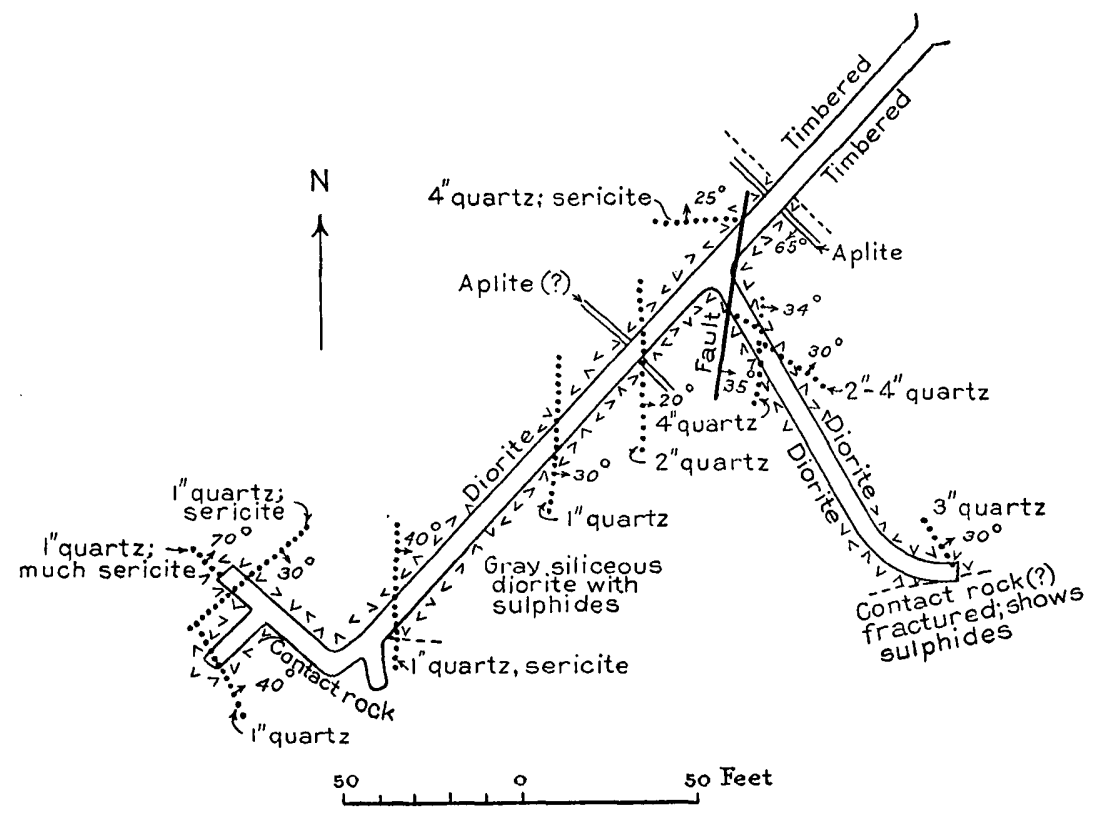

FIGURn 5.-'Tunnel on Hice prospect, Mormon Basin, Oreg.

HICE

The Hice tunnel is on the hillside about 2,000 feet south of the Humboldt. There are about 400 feet of workings, consisting of a tunnel about 250 feet long with several short branches. (See fig. 5.)

The principal country rock is partly albitized diorite, a local variant of the widespread quartz diorite of the district, with some included hornfels and a few thin dikes of albite aplite. A good many thin quartz veins ranging between one-fourth inch and 4 inches in thickness are present; the most prominent strike nearly north and dip east at flat angles. Considerable sericite accompanies these veins, and locally the diorite is silicified and impregnated with sulphides. Ankerite is a prominent constituent of the quartz veins.

No production has been reported from this prospect. 


\section{BLUE MUD}

The Blue Mud prospect, owned by R. L. Gorman, is about 1,500 . feet southeast of the Humboldt mine.

The property is developed by means of several tunnels, now caved, and a shaft about 200 feet deep. This work is in Tertiary gravel and pre-Tertiary greenstone, chloritic schist, and gabbro. It has been carried on in search of the bedrock source of very rich float found in the Tertiary gravel just down the hill to the north.

The shaft, whose mouth is in Tertiary gravel and which penetrates greenstone and metagabbro below a depth of about 100 feet, was full of water at the time of visit, but a lower tunnel, whose adit is just north of the contact between the Tertiary and pre-Tertiary rocks on the west side of Basin Creek, at the head of the canyon, was being driven to tap it at a lower level and drain it for working. In this tunnel, which was less than 100 feet long at the time of visit, is an excellent exposure of the fault contact between the Tertiary gravel and the pre-Tertiary rocks. Considerable water was coming into the drift at this contact. According to William Phalen, the water in the shaft was also derived either from this fault or immediately below it. An excellent vein is reported to have been cut in this shaft, and it is hoped that completion of the drain tunnel will permit its further development.

\section{INTERMOUNTAIN}

The Intermountain property is just west of the confluence of Rainbow Gulch and the South Fork of Dixie Creek. It is opened by a tunnel about 1,000 feet long, the inner part of which was caved and inaccessible at the time of visit. The accessible portion of the workings was entirely in quartz-mica schist, slate, and limestone of the "schist series." A few small calcite stringers were cut, and according to Mr. Smith, of Baker, a few tons of silver ore had been obtained from one of these veins. Specimens from one of these veins contain polybasite in a calcite-quartz gangue. No work had been done in this tunnel for several years, the present endeavors of the owners being concentrated on a new tunnel, higher up the hill.

CLEVELAND DEVELOPMENT CO.

The Cleveland Development Co. has 15 claims on the south side of California Gulch above the confluence with Basin Creek.

The workings were all inaccessible at the time of this survey, but according to Parks and $\mathrm{Swartley}^{2}$ they originally consisted of two tunnels and several pits. The lower tunnel penetrated Tertiary sediments and then schist and greenstone, finally following a porphyry

2 Parks, H. M., and Swartley, A. M., op. cit., p. 56. 
dike that contained a few quartz seams. The dike is a few feet wide, strikes N. $75^{\circ} \mathrm{E}$., and dips steeply south.

No production has been reported from the property, and apparently no work had been done for many years prior to this survey.

\section{GIRAFFE}

The Giraffe claims were not visited during the present survey but have been described as follows: ${ }^{3}$

This company consists of seven claims on the east slope of Clark's Creek, in sec. 31 , T. 12 S., R. 42 E., about $1 \frac{1 / 2}{2}$ miles ${ }^{4}$ north of the Humboldt mine. The ore is a narrow mineralized granodiorite porphyry dike in a country which is largely argillite but also has serpentine and dikes of basalt. A considerable body of lime is a short distance to the north of the property and granodiorite to the east.

On the Giraffe claim No. 1 a drift upon the dike was made from which 200 tons were milled and $\$ 7.50$ per ton was recovered on the plates. A recent independent sampling of this drift gave an average of $\$ 4.20$ per ton. About 750 feet north of the above drift, on the Giraffe No. 2, a crosscut tunnel cuts the dike at a depth of 85 feet, where the values are about the same as above. A crosscut is being driven on this claim to cut the dike at a depth of 300 feet. This crosscut will be about 500 feet long and is now about halfway in.

This information was furnished by officers of the company.

\section{MORTON}

The Morton prospect, owned by the Morton brothers, of Vale, Oreg., is on the divide between Glengarry and French Gulches near the west side of the Mormon Basin. The prospect is entirely in an old soil of Tertiary age made up of decomposed quartz diorite débris, which the shaft, reported to be 96 feet deep, has failed to penetrate. This decomposed diorite contains considerable very rich quartz float, but the parent vein has not been found.

\section{OTHER PROSPECTS}

A great many other prospect tunnels have been driven in the decomposed quartz diorite on the north side of French Gulch, beneath the andesite capping of the ridge between Glengarry and French Gulches, also in search of the source of the rich quartz float that is so common in the area, but without success.

\section{PLACER MINES}

Placer mining in the basin has gone on intermittently since 1863 , but owing to shortage of water the output has never been very great, although exact figures are not available. An attempt to operate a dredge on the north side of Basin Creek just east of the Humboldt

s Parks, H. M., and Swartley, A. M., op. cit., p. 99.

4 Sec. 31 is $3 \frac{1}{2}$ miles north of the Humboldt mine.-J. G. 
mine was unsuccessful for the same reason. At the time of this survey some work was being done in the gravel of French Creek, but returns were hardly more than day wages for the few men engaged in it.

Most of the production has come from the stream gravel, which includes not only concentrations from the bedrock series but reworked gravel from the Tertiary formation, which itself carries considerable auriferous quartz. The effect of this reconcentration has been to produce some rather rich though small deposits.

\section{OUTLOOK FOR THE DISTRICT}

The Mormon Basin district contains much mineralized ground, as has been proved from the work done. Surface exposures are not good, owing to Tertiary gravel and forest cover in places, so that other veins than those known are probably present in the district. The fact that the Rainbow mine was profitable for several years demonstrates that the area has merit. Disadvantages of the district include the considerable distance to a railroad and the more important fact that although veins are numerous, as a rule they do not appear to be persistent over long distances. The tenor of the ore is sufficient, if considerable tonnage could be developed, to make mining profitable. At the time of this survey such tonnage had not been developed, although more work might well prove it to be present. Some of the small veins might prove profitable if worked in the oxidized zone by a few men in a small way, but the fact that the ore becomes base at a relatively shallow depth seems to set a limit to this kind of work. Larger tonnages than were developed in 1930 would be needed to justify a mill to work the base ores.

\section{CONNOR CREEK DISTRICT}

\section{GEOGRAPHY}

The Connor Creek district is in Ts. 11, 12, and 13 S., R. 45 E., on Connor Creek, a tributary of the Snake River, which enters the canyon about 14 miles north of Huntington, Oreg.

The post office of Home, on the Robinette branch of the Oregon Short line, serves the district. The principal workings are about 3 miles by road from this station. The topography of the district is extremely rugged, altitudes ranging from about 2,000 feet on the Snake River to nearly 7,000 feet on the ridges a few miles to the west. The climate in the lower canyon is hot in summer and mild in winter.

\section{FIELD WORK}

Owing to the inactivity in the district, field work was confined to a two day's visit. Only small amounts of workings were accessi- 
ble, so that no mapping was attempted. Little can be added to the descriptions of Lindgren ${ }^{5}$ and Swartley. ${ }^{\circ}$

\section{GEOLOGY}

The dominant rock formation is a series that ranges from black carbonaceous slate to quartz phyllite. A little greenstone and chloritic schist also occur and, toward the top of the formation, some considerable masses of limestone. These rocks have been referred to the Triassic by Lindgren, though without fossil evidence. They strike N. $20^{\circ}-45^{\circ} \mathrm{E}$. and dip steeply northwest. West of the district they are intruded by granitic rocks. A few porphyry dikes occur within the district.

The ore deposits are quartz veins that trend northwest and dip steeply southwest.

\section{THE MINES}

\section{CONNOR CREER}

The Connor Creek mine is on the hillside west of the North Fork of Connor Creek, about $2 \frac{1}{2}$ miles above the Snake River. At the time of visit the mine was closed and the workings caved and almost wholly inaccessible. The following account is in large part summarized from Lindgren's report.

The vein was discovered in 1871 by Wood and Edelmann. In 1872 a 5-stamp mill was operating on $\$ 23$ gold ore. In 1876 a 15-stamp mill was erected. The mine was worked almost continuously until about 1901, but the greatest productivity was between 1880 and 1890 . In 1884 the Connor Creek Mine \& Mill Co. bought the property for $\$ 60,000$. In 1900 there was a 35 -stamp mill in operation with plate amalgamation and concentrators. A little ore was mined each year until 1910, when the mine closed. In 1915 the property was turned over to the Connor Creek Mines Co. on a lease, ${ }^{7}$ but it reverted after three years to the Connor Creek Mine \& Mill Co., although a small production had been made and a 10-stamp mill erected in 1917.

The production of the mine is not accurately known but was estimated by Lindgren in 1901 at not over $\$ 2,000,000$. A small production was made in 1915-1918, but this was probably not over $\$ 20,000$.

The mine was developed by six tunnels over a vertical interval of 1,000 feet. The lowest, the Connor Creek, included 3,700 feet of workings. The Dry Creek level, 150 feet higher, was 1,400 feet long. Above this were the Bulger, 1,200 feet; the Lower, 610 feet; the Middle, 577 feet; and the Upper, 486 feet long. With the raises there was well over 8,000 feet of development work.

\footnotetext{
${ }^{5}$ Lindgren, Waldemar, op. cit. (1901), pp. 756-758.

- Swartley, A. M., op. cit., pp. 213-217.

7 Personal communication from Albert Geiser, Baker, Oreg., 1930.
} 
The mine is entirely in slate and greenstone. The vein strikes N. $40^{\circ} \mathrm{W}$. and dips $70^{\circ}-75^{\circ} \mathrm{SW}$. The vein has been stoped from the Dry Creek level practically to the outcrop, but between the Dry Creek and Connor Creek levels it was much crushed and was mined only in part. The stopes were bounded on the west by a break or fault called the "final cut-off," which strikes N. $31^{\circ}$ E. and dips $45^{\circ}-60^{\circ} \mathrm{SE}$. Along this break a shear zone of chloritic puckered clay slate about 130 feet wide occurs. Only on the Connor Creek level was the vein found west of this zone.

The vein is cut by several minor faults. Along its entire course it follows the footwall of a greenish, highly altered and pyritic dike rock. The slate is likewise highly pyritic along the vein. The vein ranges in width from a narrow seam to 8 feet, but the average is between $1 \frac{1}{2}$ and 4 feet. The filling is white coarse quartz that contains coarse gold, almost entirely native, with some argentite and pyrite. The gold was worth $\$ 19$ to $\$ 20$ an ounce, being unusually fine. The quartz was partly massive, partly ribboned. Where large masses of pyrite occurred the amount of gold decreased.

The highest assays of the vein were obtained where it was 3 to 4 feet thick. The main pay shoot, which was irregular in outline, was 1,400 feet long on the Dry Creek level and extended to the surface. The milling ore of this mass ran between $\$ 3$ and $\$ 10$ in gold to the ton. Within the shoot smaller and richer bodies carrying coarse gold occurred. One of them pitched $60^{\circ} \mathrm{NW}$. in the vein and was about 60 feet in pitch length by 10 feet along the level. From this body $\$ 120,000$ was recovered, some argentite being associated with the gold. The rich ore was locally concentrated in a 1-foot thickness of quartz, along either the footwall or the hanging wall; elsewhere it was irregularly distributed through the entire thickness of the vein. There was little evidence of enrichment.

IIDDY

J. J. Liddy has done considerable prospecting on the east fork of Connor Creek in sec. 34, T. 11 S., R. 45 E. The country rock is chiefly limestone, interbedded with black slate and greenstone, with a few dioritic dikes. Several tunnels have been driven. In the longest one, about 800 feet long, no veins were cut, but one of the shorter tunnels cuts a short thick lens of low-grade quartz fully 20 feet thick but faulted off on both ends. It is reported by Mr. Liddy to run about $\$ 10$ to the ton in gold. The vein is much crushed and the quartz sugary.

\section{MOLIIN}

The deposit known as the Mullin prospect, discovered in 1914, is on the north side of the district, near Soda Creek. It is about $1 \frac{1}{2}$ 
miles from the railroad. The claim was not visited, and the following description is summarized from Swartley's report. ${ }^{8}$

The country rocks are limestone and schist of obscure bedding, but the schistosity strikes $\mathrm{N}$. $70^{\circ} \mathrm{E}$. and dips $80^{\circ}-90^{\circ}$. These rocks are cut by two veins. One 2 -foot vein of milky quartz containing native gold and tetrahedrite strikes N. $40^{\circ}-45^{\circ} \mathrm{W}$. and dips $60^{\circ} \mathrm{SW}$. and has been traced about 300 feet; the other vein consists of barren quartz and calcite, strikes N. $55^{\circ}$ E., and dips $80^{\circ} \mathrm{NW}$. to $90^{\circ}$. The auriferous vein is supposed to cut this barren vein and near the top of the ridge is itself cut and displaced by a 30 -foot basalt dike.

Development work at the time of Swartley's visit was confined to open cuts in which variable assays as high as $\$ 60$ to the ton were obtained.

\section{RUNWER}

Swartley's description ${ }^{9}$ of the Runner claims, which were not visited in the present survey, may be summarized as follows:

The group is about a mile southwest of the Mullin property. The country rock is schist cut by numerous reticulated quartz veins that impregnate the schist. The rock cut by these veinlets is all auriferous. Two crosscuts were driven on the property. Channel sampling is reported to have yielded $\$ 3.26$ a ton over a width of 90 feet, with no samples below $\$ 1$.

No further information was obtained about this property.

PLACER MINES

Placer mining in the area dates from the early days, at least as long ago as 1870. The old gravel of Connor Creek has been partly buried by landslide and talus material, so that considerable drift mining has been done in the placer deposits along this stream. In 1930 there were several small placer operations in this gravel. Swartley ${ }^{10}$ reports that the total placer gold production to 1914 was about $\$ 125,000$. The current production is small, and no large returns are made, but the mining is cheap, and presumably wages earned are sufficient to justify the work.

\section{BAY HORSE}

The Bay Horse mine is just west of the Snake River, about 7 miles below the mouth of the Burnt River and close to the Robinette branch of the Oregon Short Line.

The mine, which was first opened many years ago, was most active from 1920 to 1925 and made some shipments, of silver and 
copper ore to the smelter at Tacoma. The total production has not been great. The mine was abandoned and inaccessible at the time of visit.

\section{It has been described by Livingston ${ }^{11}$ as follows:}

Silver-bearing tetrahedrite, or rather the arsenical variety tennantite, is generally the sole ore mineral, but it is associated in places with rather small quantities of other sulphides. The ore occurs in a fractured zone close to the contact between the Permian andesite and the rhyolite flow and probably does not extend into the overlying Triassic sediments. It occurs both as an impregnation in the rhyolite and as replacement of the andesite. In the impregnations mineralization extends some distance into the rhyolite and forms a low-grade ore. The replacements in andesite are somewhat irregular in outline but appear to be persistent in strike and dip westward into the mountain. They are highly silicified masses, which are similar in appearance to the overlying rhyolite and contain numerous equispaced veinlets or stringers of tennintite. The general strike of the ore bodies is about $\mathrm{N} .70^{\circ} \mathrm{W}$, parallel to the stratified rock and the rhyolite. The ore body on which most of the mining has been done has a maximum width between 40 and 50 feet. It is badly faulted on the main tunnel level, and much of the ore mined during 1922 was drag ore, lying in a flat fault plane which dipped to the south; this fault obscured the nature of the ore occurrence to a considerable extent. A good deal of the ore was shipped as it came from the stopes, though sorting was practiced to a considerable extent. The westward limit of the ore body has not yet been reached and the present development is outlined to follow it into the mountain. Recent developments indicate that the ore shoot occurs at the junction of two faults, that it strikes roughly west, and dips into the mountain on a grade of 10 feet in every hundred.

The mine is opened by two tunnels, both of which were started years ago. The present operators have pursued development in the upper one, which has been driven into the mountain about 800 feet. A number of crosscuts and stopes connect with it. A winze from a level about 60 feet below this tunnel is now opening up a body of excellent ore in the andesite below the fault on the upper tunnel level. The lowest tunnel, which is about 130 feet below the uppermost, has not as yet been reopened by the present company, although work in the tunnel is contemplated in the near future. The property is owned by the U. S. Metals Co. of Portland, Oreg.

The outcrop is very small and its only indication of mineral is an azurite stain. As the ore zone contains practically no vein quartz, it is impossible to distinguish the weathered outcrop from the country rock except by the copper stain. This fact should be borne in mind when prospecting in other places along this mineralized horizon. Copper staining occurs opposite the Bay Horse on the Idaho side of the Snake near the andesite-rhyolite contact, but no extensive development has been carried on at this point. Similar evidence of mineralization is reported to occur on Rock Creek, also in Idaho, but time was not available to investigate the geology of this area.

According to a published note ${ }^{12}$ the ore body outside of a highgrade streak whose tenor is not recorded, ran 15 ounces to the ton

11 Livingston, D. C., A geologic reconnaissance of the Mineral and Cuddy Mountain mining district, Washington and Adams Counties, Idaho: Idaho Bur. Mines and Geology Pamphlet 13, pp. 17-18, 1925(?).

$12 \mathrm{Eng}$. and Min. Jour.-Press, vol. 115, p. 291, 1923. 
in silver. Flotation experiments were conducted, but it is not known whether a mill was ever built. If so, its operations were not long continued.

\section{OUTLOOK FOR THE DISTRICT}

The district is readily accessible to the railroad, but so few mine workings were accessible in 1930 that no adequate basis was available for a judgment as to its prospects. The long and fairly prosperous activity of the Connor Creek mine and of the placers along the creek are encouraging features, but nothing was learned that would give any guide in the search for further deposits.

\section{GOLD HILL DISTRICT}

\section{LOCATION AND GEOLOGX}

Gold Hill forms the northeast wall at the entrance of the lower canyon of the Burnt River, about 4 miles southeast of Durkee. The main line of the Oregon-Washington Railroad \& Navigation Co. passes through this canyon, so that transportation facilities are excellent.

The dominant rocks are schists with some limestone lenses, referred by Lindgren ${ }^{13}$ to the Triassic, into which is intruded a stock of quartz diorite. Diorite porphyry dikes related to this stock are numerous.

\section{THE MINES}

GOLD HILL

The Gold Hill mine is in the SW. 1/4 sec. 1, T. 12 S., R. 43 E., on the north side of Gold Hill. It is reached from Durkee by a wagon road $33 / 4$ miles long. In 1930 the property was under control of the Sawbridge interests of Spokane, Wash., with C. J. Reuscz as manager. The property consists of 20 lode claims, 1 mill claim, and about 80 acres of deeded land. No work had been done for many years prior to 1930 , but plans were under way at that time to reopen the mine. In 1914 Al Geiser, of Baker, did some work on the vein nearest the tunnel portal and recovered about $\$ 1,000$ in gold.

The mine is opened by about 4,200 feet of drifts on the main level, three shafts, inaccessible at the time of visit, and numerous small prospect cuts on the surface. No data on production are available, but the output of the mine has been small.

The country rock of the mine is almost wholly quartz diorite, although a short drift has been run on a fault contact between the quartz diorite and slate. Small quartz outcrops are numerous from top to bottom of Gold Hill, above the mine. Eight different veins have been cut in the workings. (See fig. 6.)

${ }^{13}$ Lindgren, Waldemar, op. cit., pl. 64. 
The first vein intersected by the main adit is the Spring Gulch vein, about 2 feet thick. About 600 feet of drifting has been done on this vein, which strikes about N. $60^{\circ} \mathrm{W}$. and dips steeply south. Farther south are four other parallel veins, the Judas, Bonanza, Gone Goose, and Panting. The last two were not visited because of bad

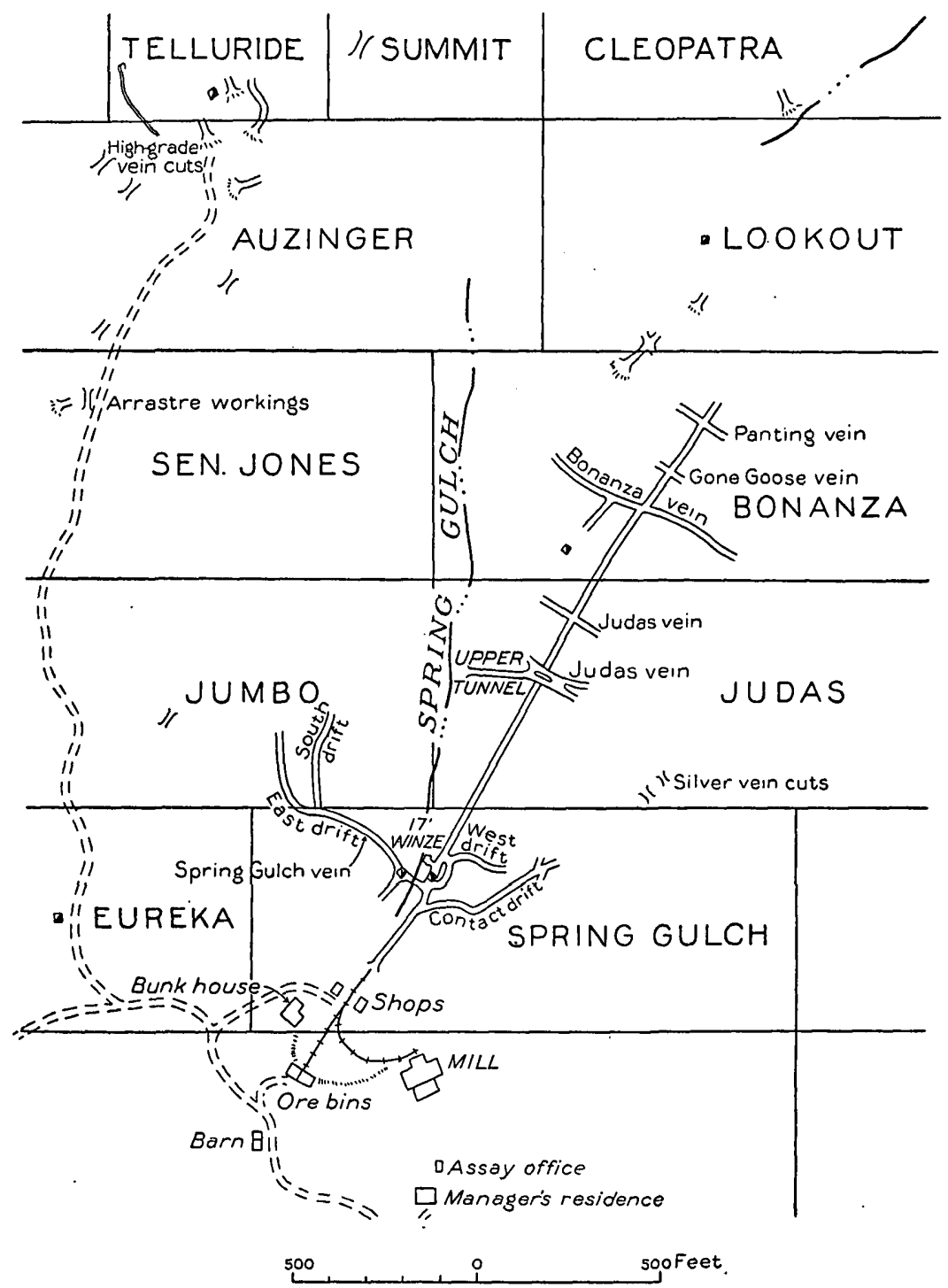

Frgure 6.-Map of workings of the Gold Hill mine, near Durkee, Oreg.

air. The strike of these veins is about N. $65^{\circ} \mathrm{W}$. and the dip $30^{\circ}-45^{\circ} \mathrm{S}$." Another vein, the Weatherby, is exposed to the south; on top of the hill, in some prospect pits. The exposures are so poor that no information can be given about this vein. 
The "contact vein," followed by the "contact drift," is a fault containing some vein matter and separates a footwall of slate from a quartz diorite hanging wall. Its strike is N. $60^{\circ}$ E. and its dip $30^{\circ}-45^{\circ} \mathrm{SE}$. Owing to bad air it was impossible to map the workings in detail.

The veins consist chiefly of quartz and sericite with some calcite. The wall rocks are intensely sericitized adjacent to the veins. The average thickness of the veins is less than 6 inches, but locally a width of 2 feet or even more may be attained. Considerable pyrite and small amounts of sphalerite and galena were seen. Serpentine is present in the faulted contact.

Assays made by D. W. C. Nelson, of Baker, which were made available through the kindness of Mr. Reuscz, showed that the Spring Gulch vein averaged $\$ 14.66$ over a width of 3 feet and the Bonanza $\$ 15.70$ over a width of 18 inches. Surface cuts on the Anzinger claim yielded quartz averaging $\$ 34.14$ to the ton, whereas the same vein yielded an average of $\$ 60$ to the ton over a width of 3 feet in the Porcupine tunnel. All the value in these assays was in gold. A sample from the surface on the Judas claim assayed a trace of gold and 32 ounces of silver to the ton.

DURKEE DEVELOPMENT CO.

The Durkee Development Co.'s property is half a mile southeast of the Rye Valley road at an altitude of about 4,000 feet and is about 5 miles by road from Durkee. It is under the management of C. L. Deerdorf and is owned by Deerdorf \& Graves, of Durkee. Development work was going forward at the time of visit.

The vein seems to be associated with a diorite porphyry dike, but exposures are too inadequate to demonstrate this relation. Some arkose in the slate series was observed on the hillside to the east of the veins. One shaft about 30 feet deep has been sunk but was caved at the time of visit. A short crosscut driven below to connect with this shaft penetrates slate and a basaltic dike.

The vein is composed of quartz and strikes north and dips about $45^{\circ} \mathrm{W}$. Pieces of vein material about a foot in diameter are present on the surface, but the greatest thickness exposed in any of the workings is 8 to 10 inches. Nothing is known of the assay value of this quartz.

\section{GOLD RIDGE}

The Gold Ridge mine is about half a mile west of the Rye Valley road, about 4 miles south of Durkee. The workings were all abandoned, caved, and inaccessible in 1930. According to Lindgren, ${ }^{14}$ the mine is opened on an old discovery and was doubtless

is Lindgren, Waldemar, op. cit., pp. 765-766. 
located soon after the placers below it. In 1881 a 10-stamp mill was built, and it was operated till 1886, when work was stopped. In 1896 a brief period of activity ensued, but the mine was again quiescent until 1900, when a 250 -foot vertical shaft was sunk. At the time of Lindgren's visit the crosscut from this shaft had not reached the veins, and information was not obtained as to whether the veins were ever cut at this level. There were 2,000 feet of tunnels in 1900 . The production was given by $\mathrm{H}$. R. Nichols as $\$ 210,000$, practically all extracted between 1881 and 1886 .

The country rock is diorite. Three veins cut this diorite; two strike $\mathrm{N}$. $50^{\circ} \mathrm{W}$. and $\operatorname{dip} 65^{\circ} \mathrm{SW}$; t the third strikes more nearly west and dips south. The veins are sharply defined, consist of quartz, and are 2 to 3 feet wide. Several branch veins occur. The ore above the tunnel level, 275 feet below the croppings, was all oxidized and ran between $\$ 12$ and $\$ 15$ to the ton, chiefly in free gold of a fineness of $\$ 18$ an ounce. The concentrates were rich, containing 8 ounces of gold and $1 \frac{1}{2}$ ounces of silver to the ton. The pay shoots on the two easterly veins were reported to be 780 feet long, whereas that on the third was considerably shorter.

The writers are able to add nothing to the information obtained by Lindgren.

\section{OUTLOOK FOR THE DISTRICT}

The accessible mine workings were too scant to give any adequate basis for an estimate of the possibilities of the Gold Hill district: The veins so far found, although of good tenor, appear too small to justify work on a large scale, but they may prove profitable if worked in a small way with a minimum of overhead. Larger veins may be found by further exploration.

\section{SPARTA DISTRICT}

GEOGRAPHY

The Sparta district is in Ts. 7, 8, and 9 S., R. 44 E., on the southern foothills of the Wallowa Range, where they slope down to the lower Powder Valley. Altitudes range from about 2,300 feet to nearly 5,000 feet. The district is reached by an excellent automobile highway from Baker to the lower Powder River Valley, from which somewhat inferior but still fairly good roads run into the foothills. The distance from Baker to Sparta is about 40 miles by these roads.

\section{GEOLOGY}

The principal rocks underlying the district are quartz diorite and albite granite of presumable Mesozoic age, intrusive into Per164495-33-5 
mian greenstone, which is only locally represented. Overlying these rocks and separated from them by a profound structural and erosional unconformity is basalt of the Columbia River lava. A few basalt and diabase dikes, possibly feeders for these flows, cut the older rocks.

From the regional distribution of the Permian greenstone it is supposed to strike slightly north of west, but local observations to confirm this inference are lacking, owing to the scanty exposures and considerable metamorphism of these rocks. The granitic rocks, which constitute a much more abundant unit in the district, are almost massive-that is, free from gneissic banding-although they are considerably sheared and broken. The Columbia River lavas. lie with gentle south dips across the older structure.

The mineral deposits of the district, aside from the long inactive placer workings on the plateau near Sparta, are all gold quartz veins in quartz diorite and albite granite. Some of these veins are very rich, but those so far found are mostly narrow and nonpersistent.

\section{THE MINES}

GEM

The Gem mine, owned by Al Geiser, of Baker, is in gently rollingcountry about 2 miles west of Sparta. According to Lindgren. ${ }^{-15}$. from whose report the following description is largely taken, the mine was located in the early days, a 10-stamp mill being erected in 1873. The mill was removed to Connor Creek in 1875, and the mine was idle for a long time. Just prior to 1900 there was renewed activity, but this lasted for only a short time. In 1919 a nominal production was reported. The mine had been closed down for many years before 1930 and was inaccessible at the time of visit. A plan and section of the mine have been published by Swartley. ${ }^{16}$

No data on the production of the mine are available, but the output was undoubtedly moderate.

The mine was developed by a vertical shaft 500 feet deep, several inclines, and eight drifts on different levels.

The country rock is albite granite, with some aplite. The normal. rock is pseudoporphyritic with large blebs of bluish quartz, locally attaining 1 inch in diameter, in a coarsely crystalline groundmass: of albite, quartz, and epidote. The vein, which strikes north and. dips $40^{\circ}$ E., shows well-defined walls 1 to 4 feet apart and consists. of sheared granite horses in coarse vein quartz. The minerals: present include free gold, pyrite, and zinc blende. Near the shaft 
the vein cuts a granite porphyry dike without change in character, but on the second level south it is cut off by a basalt dike which strikes east and dips $60^{\circ} \mathrm{S}$. and along which faulting has occurred.

\section{CRYSTAL PaLACE}

The Crystal Palace mine, controlled by S. A. Work, of Boise, Idaho, is about $21 / 2$ miles west-southwest of Sparta. Its production has doubtless been small, but figures are not available.

The property is developed by two tunnels 80 feet apart vertically and by inclined raises and winzes from them. The workings aggregate about 2,000 feet. (See fig. 7.)

The country rock is albite granite, cut by diorite porphyry dikes (not separately mapped) and by several much younger basaltic and diabasic dikes that range in thickness from less than an inch to 20 feet.

The granite is sheared and locally silicified along these shear planes. Quartz veins follow several of these shear surfaces and probably are chiefly replacement veins localized by them.

The vein is much more continuous and uniform in the upper tunnel than in the lower tunnel, where the most recent work has been done. In the upper tunnel its average strike is about $\mathrm{N}$. $35^{\circ}$ W. and its dip about $27^{\circ}$ E., whereas in the lower tunnel it ranges in strike from $\mathrm{N}$. $30^{\circ} \mathrm{W}$. to N. $60^{\circ} \mathrm{E}$., with a peculiar S-shaped curve. This curve may be due either to postmineral or premineral movement; the exposures are insufficient for clear decision. The vein quartz is more or less crushed, showing clearly that there has been postmineral movement, but the amount is difficult to judge. In places the fissures contain no quartz and are marked by sericitic and ankeritic crush zones. The vein ranges in thickness from a knife-edge to about 7 feet, and the average is about a foot.

The mineralogy of the veins is simple. The sulphides are pyrite and arsenopyrite in a gangue of quartz, sericite, chlorite, and ankerite.

\section{MACY}

The Macy mine is in the northwest wall of Maiden Gulch about a quarter of a mile above the junction with the Powder River. The mine was located about 1920 by the Macy brothers, of Sparta, and in 1930 was being developed under bond by the Mines Development Co., W. J. Geer, manager.

The property is developed by three tunnels and two short inclines. The lower tunnel includes about 200 feet of crosscuts and 400 feet of drifts; 26 feet higher is a 200-foot drift; and 40 feet above this is the upper level, on which a drift has been run for about 100 feet. 
CONTRIBUTIONS TO ECONOMIC GEOLOGY, 1933 , PART 1

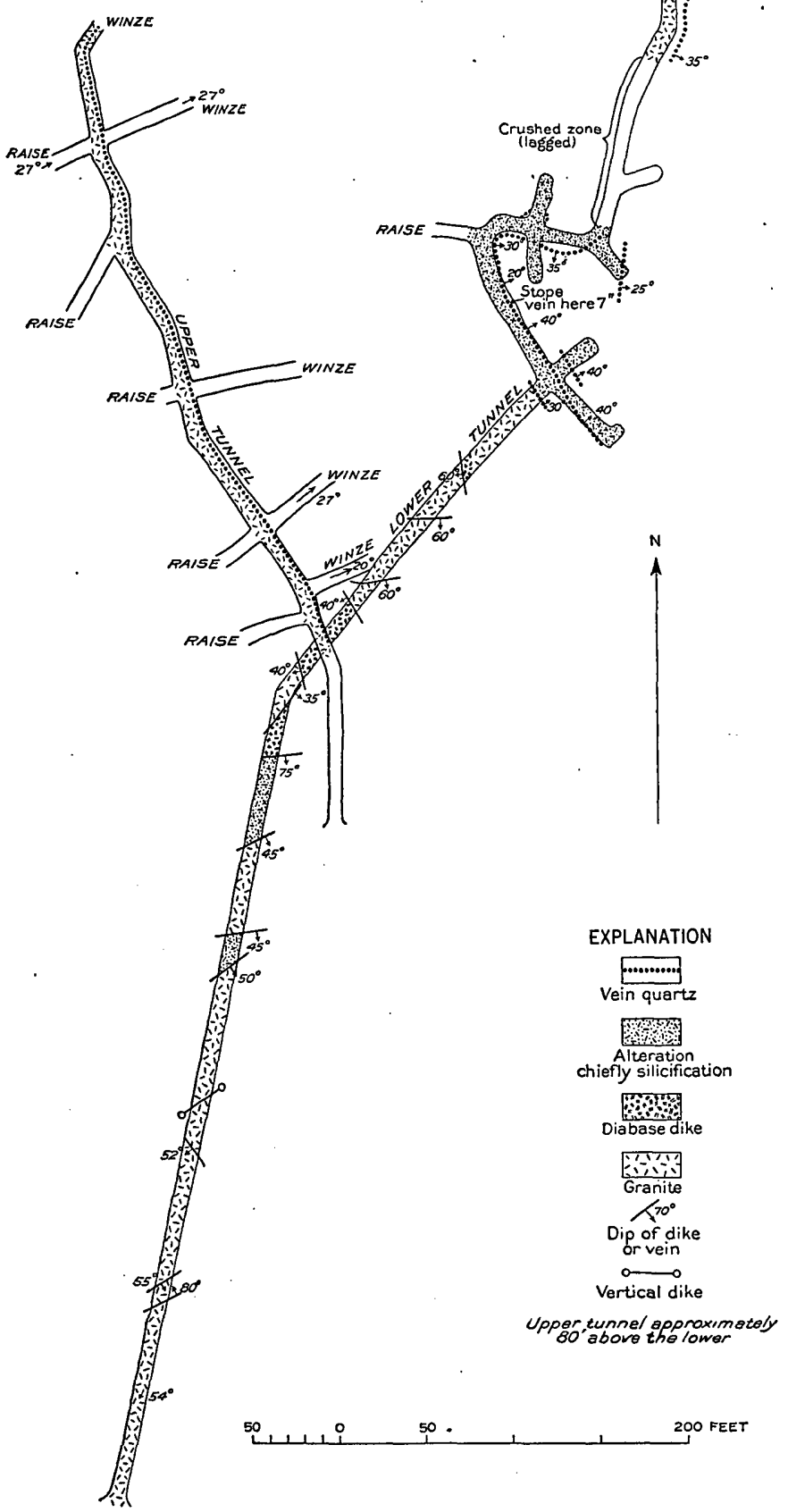

Figure 7.-Map of the Crystal Palace mine, Sparta district, Oreg. 
Farther up the hill to the north are two short inclines. Altogether about 1,000 feet of development work has been done. (See fig. 8.)

The production has been small, but some has been reported for 1922, 1923, and 1926. At the time of visit a small mill was being installed and was expected to be in operation in the fall of 1930 .

The country rock of the mine is albite granite, which grades into quartz diorite. Higher slopes to the north and east are capped by diabase and basalt flows of the Columbia River lava.

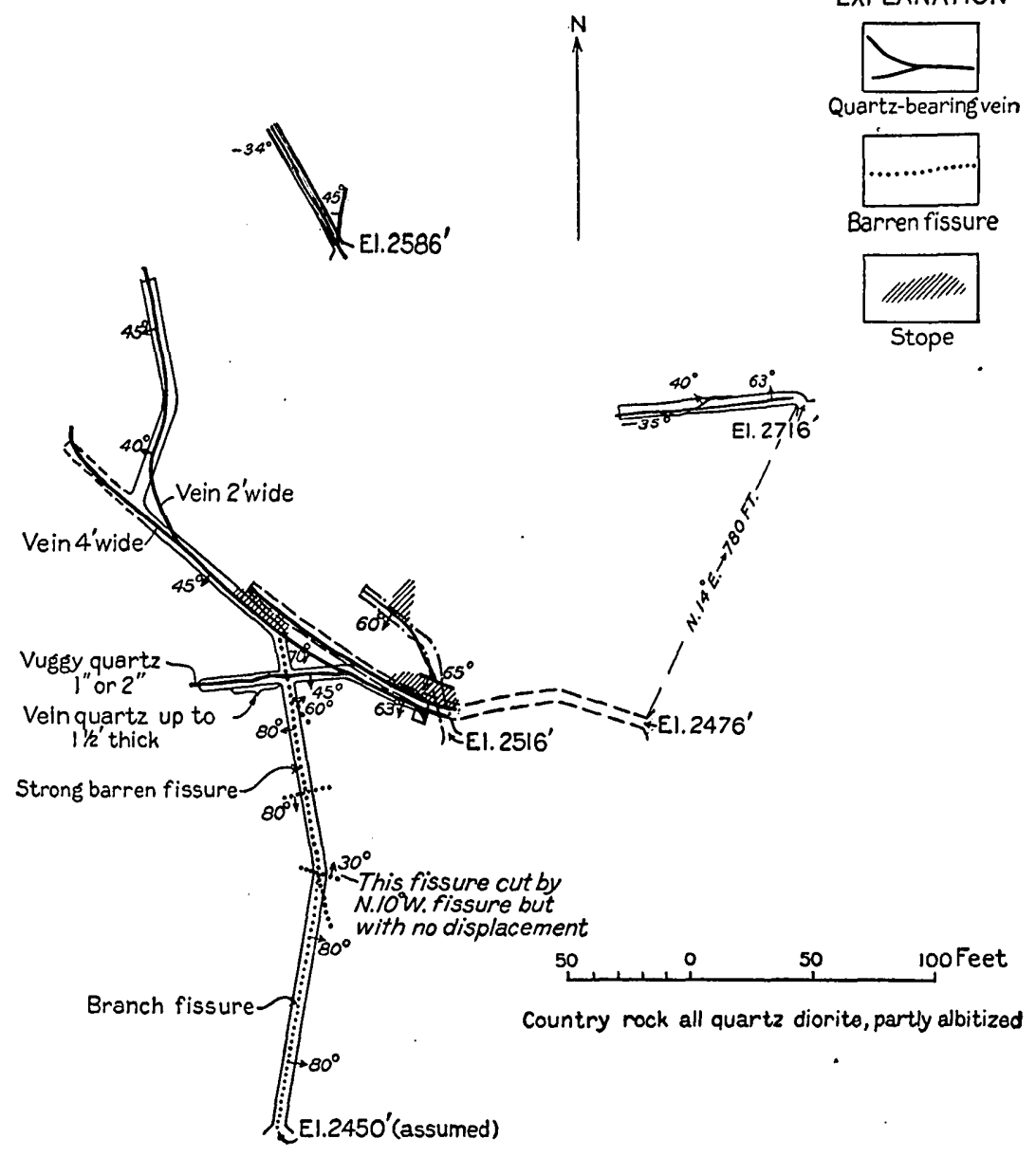

EXPLANATION

Figure 8.-Map of the Macy mine, Sparta district, Oreg.

The mine develops a quartz vein with several branches. The trend of the main vein is about $\mathrm{N} .50^{\circ} \mathrm{W}$., and its dip ranges from about $75^{\circ}$ to $40^{\circ} \mathrm{S}$. Branches toward the north, northwest, and westsouthwest are seen on the lowest level. The two inclines above the main workings follow separate veins; the lower strikes northnortheast and dips $45^{\circ} \mathrm{W}$; ; the upper strikes nearly east and dips $40^{\circ}-63^{\circ} \mathrm{N}$. 
The veins exposed range in width from about an inch to about 4 feet, with an average, where worked, of about 1 to $1 \frac{1}{2}$ feet. For the most part the walls are well defined, in many places demonstrably fault surfaces. The vein quartz itself is commonly brecciated, and most of the sulphides are localized in these brecciated places. Locally the veins are vuggy, elsewhere they are massive, and at still other places the space between the walls is filled with gouge and only subordinate amounts of quartz. Stoping has been carried through between the two lower levels just west of the lower crosscut and from the lowest to the upper level, about 20 feet from the upper portal. The stope length of each of these shoots is about 20 to 25 feet, the veins pinching down to unminable thinness in both directions.

The veins are composed chiefly of quartz, with sericite, chlorite, and calcite, containing pyrite, sphalerite, and free gold. Clay and limonitic material are the weathering products. Assays were not available, but it is evident from the visible free gold that some of the material is extremely rich. However, the veins so far exposed are not regular nor persistent enough to establish a confident expectation of continuing to great depths.

\section{PLACER MINES}

The placer mines of Sparta have long been inactive, and the old Sparta Ditch, which supplied water from Eagle Creek for many years, beginning in 1873, has long been withdrawn from mining use. In fact, no water is now brought in it for irrigation. The gold was found in the residual soil of the deeply weathered granite near Sparta and doubiless was derived from the numerous small but rich veins similar to those seen in the mines of the district. The topography is not suited to other than sluicing methods of recovery, so that a revival of placer mining is unlikely.

\section{THOMAS}

H. C. Thomas has three and one-fourth claims in the Sparta district, about 2 miles south of Lily White. They lie on a side road a mile west of the road from Sparta to Lily White and are a short distance east of Goose Creek, on the hill above the Daddy Lode mine. The claims are the Coin, the Eclipse, and the Sovereign.

Most of the development work has been done on the Coin claim. There are two tunnels now accessible on this claim, one of which extends for a distance of approximately 600 feet and the other for 150 feet. In addition, a small shaft about 40 feet deep has been sunk, as well as several small prospect holes. The Eclipse claim has a 30 -foot shaft, now inaccessible, as is the 80 -foot shaft on the Sovereign claim. A considerable proportion of the work has been done under bond by John Arthur, of Baker. 
The country rock of the region appears to be a highly silicified, probably originally dioritic intrusive igneous rock. In the larger tunnel on the Coin claim several faults were noticed which trend about $\mathrm{S} .25^{\circ} \mathrm{W}$. and dip at various low angles, about $30^{\circ} \mathrm{W}$. Gouge is developed along these slips, and they appear to be centers of sericitization.

Most of the ore found has been as chunks and boulders in the fault zones. The ore is chalcopyrite, in part altered to malachite and limonite. The gangue is either quartz or barite or both. No bodies of minable size have been found. Galena and sphalerite are also found in boulders and locally in small veins in the country rock. These minerals have the same gangue as the chalcopyrite, with which they are locally associated.

\section{OUTLOOK FOR THE DISTRICT}

The occurrence of rich placer ground on the plateau near Sparta gives evidence of considerable mineralization. The veins that have been developed have given very encouraging assays, but nevertheless there have been no developments sufficient to justify large mining activity, doubtless because of the lack of persistence in the individual veins. The considerable amount of gold undoubtedly present has not been concentrated in a few large veins but has been deposited in numerous narrow and discontinuous ones. Several of the properties show developments encouraging to work in a small way; mining on a large scale must await the discovery of more persistent and larger veins than were accessible in 1930.

\section{EAST EAGLE DISTRICT}

\section{LOCATION AND GENERAL FEATURES}

The East Eagle district lies on the southwest flanks of the Wallowa Mountains, in Ts. 6 and 7 S., R. 44 E. It is accessible by good mountain roads from the Powder Valley and is about 45 miles by road from Baker. The district lies on the hills near the junction of East Eagle Creek with the main stream.

The country rock is chiefly Triassic limestone and greenstone, cut by dikes of both granitic and diabasic rocks.

THE MINES

\section{AMALGAMATED MINES CO.}

The Amalgamated Mines Co. controls 21 unpatented claims near the head of Paddy Creek, in the southern part of the Wallowa Mountains. Most of the claims lie in sec. 35, T. 6 S., R. 44 E. Mrs. G. J. Burnham is mine manager at the property, and W. Burnham, box 1928, Spokane, Wash., is secretary of the company. 
In addition to numerous prospect pits and small open cuts there is considerable underground work, much of which was inaccessible at the time of this survey. The accessible workings consist of two adits aggregating about 1,500 feet, including short crosscuts, as shown in Plate 3. The lower and upper adits are connected by a 40-foot raise.

A small Chile mill, situated below the portal of the lower adit, had been in operation for only a few days at the time of this survey, and no clean-up had been made. It was milling ore that had been stored from a previous period of activity. No assays were available. The mine foreman estimates the capacity of the mill at 25 tons a day. Water power is used, the water coming from the head of Little Eagle Creek.

The principal country rock of the vicinity is fine-grained greenstone. Locally the rock is a coarser breccia; some conglomeratic beds are present and carry pebbles as much as 2 inches in diameter. The rocks are excessively jointed in several directions, so that hand specimens are usually bounded by joint planes. These rocks have been assigned to the Triassic by Lindgren ${ }^{17}$ and to the Carboniferous (?) by Ross. ${ }^{18}$

At least two systems of faults are present. The representatives of the more prominent system trend northwest and dip northeast. Those of the other set also trend northwest but dip steeply southwest.

Gouge is developed along the slips. The greenstone is in most places crushed along both walls of a fault, locally for a width of 20 to 30 feet. This condition is especially well seen at the places where the two crosscuts are turned from the main lower adit.

Mineralization and alteration have taken place along some of the faults, and the rock is bleached in many places, locally on both sides of the fault and elsewhere on only one side. Sericite, fuchsite, limonite, and quartz were recognized in these zones. The mineralization has been variable, and any or all of the above minerals may be present or absent at any one place.

\section{SUMMIT MINING CO.}

The Summit Mining Co., of which W. H. Strayer, of Baker, is secretary, controls a group of claims on the west side of East Eagle Creek, about 3 miles above the confluence of that stream with Eagle Creek. A few of the claims extend over the divide west of East Eagle Creek into the drainage of Bradley Gulch, a tributary of Eagle Creek. Originally the claims now controlled by the Summit Mining Co. belonged in two groups-the M. R. Woodard group and the Dunham Miles group. 
A caved tunnel on the Summit claim is reported to have produced $\$ 30,000$ at a time when most of the claims were controlled by a Mr. McGee.

The property is only partly developed. Besides numerous prospect pits, three adits, each between 100 and 200 feet long, were examined.

The predominant country rock of the vicinity is greenstone, mapped as Triassic by Lindgren and Ross. Some limestone; shale, and conglomerate are present in the greenstone series. The greenstone is gray, brick-red, or dark green. The regional strike may average about $\mathrm{N} .10^{\circ} \mathrm{W}$, and the dips are uniformly steep to the west.

The Triassic rocks are cut by much later basic dikes, which may be feeders for the Tertiary basalt blanket that still partly covers the area.

Midway.-The Midway claim of the Woodard group lies on the west side of East Eagle Creek about two thirds of the way to the divide above the creek. The rock is red shale and greenstone that strikes $\mathrm{N} .12^{\circ} \mathrm{W}$. and dips $60^{\circ} \mathrm{W}$. The vein is exposed in a small prospect pit and may be traced by float for several hundred feet. It is about 6 inches thick, strikes N. $85^{\circ} \mathrm{E}$., and dips $50^{\circ} \mathrm{N}$. The contacts against the basic dike hanging wall and greenstone footwall are sharp.

The vein material is white quartz. Other minerals seen were chalcopyrite, limonite, malachite, and a minute flake of native gold.

Apex.-The Apex claim, belonging in the Miles group, is on the ridge above the Midway claim. There are several prospect pits on the claim, the southernmost of which exposes a quartz vein 1 foot thick, which strikes N. $10^{\circ} \mathrm{E}$. and dips $25^{\circ} \mathrm{E}$. The footwall appears to be a basic dike similar to that on the Midway claim, and the hanging wall is dark-green greenstone. Two quartz stringers, 1 inch to $11 / 2$ inches thick, run from the vein into the footwall dike, thus indicating that the dike is older than the vein. However, the stringers may not be of the same age as the main vein, as they are not mineralized. The metallic minerals seen in this pit were chalcopyrite and enargite, with chrysocolla and limonite as oxidation products.

In another pit on the Apex claim, about 200 feet north of the one above described, a series of small quartz stringers, ranging from the thinness of paper to several inches in thickness is exposed.

Zenith.-The Zenith claim of the Miles group lies just north of the Apex claim and is opened by a 150 -foot adit running N. $65^{\circ} \mathrm{E}$. along a 2 to 4 foot quartz vein that dips $20^{\circ}-40^{\circ} \mathrm{NW}$. Near the face the vein appears to be cut off by a northward-trending fault, which dips steeply east. The fault appears to have the downthrow on the east, and it may be related to a larger fault that is believed to pass through 
the saddle between the Apex and Zenith claims. The country rock of the Zenith claim is greenstone.

North of the Zenith claim the ridge is blanketed by a basalt cover that attains a thickness of several hundred feet.

Woodrow.-The Woodrow claim of the Miles group is about two thirds of the way up the west wall of East Eagle Creek Valley and about a mile north of the Zenith claim. The claim is developed by a 100-foot adit and a 10-foot incline, both of which follow the vein. One of the basic dikes forms the hanging wall, and greenstone the footwall. The vein strikes north and dips $50^{\circ} \mathrm{W}$. Near the south face the vein disappears, but it was not determined whether this was a result of faulting or whether the vein pinched out.

The mineralogy is similar to that of the veins already described in this region.

The dike is well exposed a little to the north of the adit portal and across a small gulch. At this place a quartz stringer, unmineralized, occurs in the dike. The stringer trends N. $75^{\circ} \mathrm{W}$. and dips $50^{\circ} \mathrm{NE}$.

Summit.-The Summit claim lies north of the Woodrow claim. An old adit on this claim was inaccessible at the time of this survey. The portal is in conglomerate and greenstone. The vein material on the dump appears to be the same as that from the Woodrow claim.

\section{OUTLOOK FOR THE DISTRICT}

The East Eagle district is handicapped by its distance from transportation facilities but more seriously by the irregularity of the mineralization. There is little doubt that gold is present in considerable aggregate amount, but, as in many others of the eastern Oregon districts, it is in small, irregular veins, search for which is a sort of "pocket hunting." Several properties in the district may prove profitable in a small way, if their exploitation is undertaken with full regard to this irregularity, but such mining must be done with a small overhead expense.

\section{SANGER DISTRICT}

The Sanger district is in the foothills of the Wallowa Range, on the divide between Eagle Creek and the Powder River, between 5 and 10 miles northwest of Sparta. The district is reached from Sparta by fairly good forest roads; it is about 12 miles east-southeast of Medical Springs, the nearest railroad point, and is accessible by fairly good roads.

The production of the district has been derived chiefly from the old Sanger mine, long since inactive, but in 1930 mining was going on at the Basin mine, and there was some prospecting in the neighborhood of Sanger and Lily White. 
The pre-Tertiary rocks of the area are exposed only where the formerly continuous cover of Columbia River lava has been removed by erosion. About 2 miles west of the Sanger mine fossiliferous Triassic sediments crop out beneath the basalt. Although no fossils have been found near by, it is likely that the rocks in the vicinity of the Sanger mine are also Triassic, but Permian greenstone occurs in Goose Creek and Sawmill Gulch just west and southwest of Lily White. Diorite porphyry dikes and some larger diorite intrusions are present in the area.

\section{SANGER}

The Sanger mine, formerly the largest producer in the district, is in sec. 2, T. 7 S., R. 43 E., about half a mile east of Goose Creek, just north of the road between Medical Springs and Lily White. The mine has been inactive since about 1900 and was inaccessible at the time of visit. A little surface trenching was going on, as apparently it has been nearly every year since the mine became inactive. Little can be added to the account given by Lindgren, ${ }^{19}$ summarized below.

The vicinity of the mine constituted the old placer camp of Hog'em, with a reported production of about $\$ 500,000$. The principal vein, the Summit lode, was discovered in 1870 and actively worked in following years. In 1874 the production was $\$ 60,000$ from ore containing $\$ 16$ to the ton. The production to 1887 is unknown, though probably small, but a mill was then built, and in 1889 production began to increase rapidly. The Mint reports for the four years 1889-1892 give $\$ 813,000$ as the production of the mine. The mine was closed in 1897 but became active again about 1900. Since that time little work other than surface trenching has been done, although some underground work was reported in 1907, 1908, and 1921. The probable value of the output is about $\$ 1,500,000$.

The mine is developed by several tunnels and a 400 -foot shaft. An old map of the mine seems to show that work was done on two intersecting veins, but no unmistakable evidence of this was obtained.

The country rock is black slate, somewhat pyritic near the veins, which are gently dipping, well-defined quartz veins with clay selvages. The gangue was coarse quartz and a little calcite, containing about 3 per cent of sulphides, consisting of pyrite, chalcopyrite, sphalerite, and a little galena, and free gold. The principal vein is reported to have contained three pay shoots. The upper stopes were worked for 600 feet along the vein to a depth of 50 to 100 feet. The average width of the vein in these stopes was 15 inches, and its content $\$ 20$ to $\$ 25$ to the ton. Below the zone of weathering the vein was

${ }^{10}$ Lindgren, Waldemar, op. cit., p. 738. 
2 to 4 feet wide and carried $\$ 12$ to the ton in gold. This relation possibly signified residual enrichment of the vein by leaching out of valueless gangue near the surface.

\section{BASIN}

The Basin mine, owned by Dean \& Sturgill, of Baker, is an old property but has been actively exploited only in the last few years. It is about 3 miles north of the road between Medical Springs and the Sanger mine, just over the divide, on the Eagle Creek side.

Production statistics were not available, but the output must have been moderate despite the very high grade of the ores.

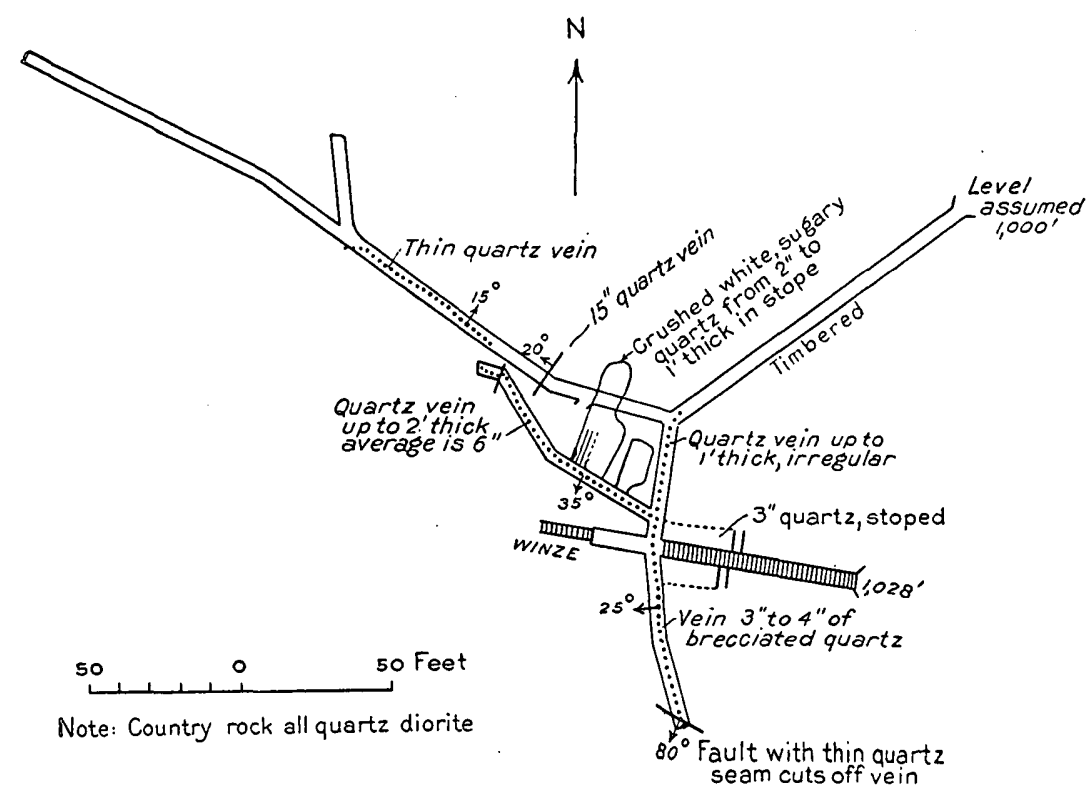

Frgure 9.-Map of the Basin mine, Sanger district, Oreg.

In 1930 the development work consisted of somewhat more than 600 feet of drifts, with some winzes, raises, and stopes. Most of the workings were on the adit level, with an inclined shaft reaching the surface about 30 feet higher. (See fig. 9.)

The country rock is quartz diorite throughout. It is cut by many joints and shear planes, the most prominent of which strike $\mathbf{N}$. $10^{\circ}-15^{\circ} \mathrm{W}$. and $\operatorname{dip} 25^{\circ}-30^{\circ} \mathrm{W}$., strike N. $60^{\circ} \mathrm{W}$. and $\operatorname{dip} 35^{\circ} \mathrm{S}$., strike N. $70^{\circ} \mathrm{W}$. and dip $15^{\circ} \mathrm{N}$., and strike N. $35^{\circ} \mathrm{E}$. and dip $20^{\circ}$ NW. Quartz veins and veinlets follow all these directions and many others. Most of the veins are narrow and discontinuous, though many are very rich, showing specks of gold in the hand specimen.

Three stopes are visible in the accessible workings. One is on a vein followed by an incline from the surface. This vein has been stoped for a distance of about 20 feet for a pitch length of about 40 
feet above the tunnel level, along the inclination of the vein. The thickness of the vein in this stope is not known; to judge from the exposures in the walls, however, it did not exceed a foot, probably averaging between 4 and 8 inches. This ore shoot is evidently the objective of the winze below the tunnel level, but the winze was full of water and could not be examined.

The other stopes are above the tunnel level, along a vein striking $\mathrm{N} .60^{\circ} \mathrm{W}$. and dipping $35^{\circ} \mathrm{S}$. This vein has been mined just above the drift for a stope length of about 30 feet. The western stope is about 40 feet high along the dip of the vein; the eastern is somewhat smaller. The quartz vein was evidently somewhat thicker than the first one described but probably did not exceed 2 feet in thickness anywhere.

The veins are all simple quartz-filled fissures along joints. Most of them show a little shearing, dominantly in the hanging wall, but can hardly be classed as faulti fissures. Considerable replacement of the wall rock has occurred. Sericite is rather common, especially along the shears. The vein matter is chiefly quartz and some chlorite and calcite, together with hematite, chrysocolla, and limonite, the oxidation products of the sulphides formerly present. A few relict sulphides occur, chiefly pyrite, chalcopyrite, and sphalerite. The quartz shows moderate brecciation.

The gold is free, within the depths obtained in the mine. The ore is variable in tenor but is locally of very high grade, wire and shot gold being common. As the veins are very narrow, this high tenor is a necessity for workability; nevertheless, the mine appears to have good prospects if worked in a small way, the lack of persistence of the veins being taken into account.

\section{MEDICAL SPRINGS DISTRICT}

\section{LOCATION AND GEOLOGY}

Near Medical Springs, Union County, sporadic work has gone on for a long time, although no production has ever been reported from the district. Medical Springs is about 18 miles by a good road northeast of Baker. A standard-gage branch extends from the main line of the Union Pacific system at Telocaset to the sawmill of the Stoddard Lumber Co. at Pondosa, a new town about half a mile south of Medical Springs.

Most of the country north of Medical Springs is covered by the Columbia River lava, but owing to the irregular topography of the surface upon which these flows were poured out and to subsequent erosion, the underlying pre-Tertiary rocks are exposed in some places. Such exposures, so far as seen in this survey, are of siliceous greenstone, apparently identical with the Permian greenstone in the 
valley of Big Creek, to the south. Exposures are poor, however, and no fossiliferous limestone such as occur sporadically in the Permian greenstones of the copper belt near Keating were seen, so that the identity of the series may not be considered established.

\section{THE MINES}

\section{TWIN BABY}

The Twin Baby prospect is about $21 / 2$ miles northeast of Medical Springs, on the divide between two tributaries of Big Creek. From Medical Springs it is reached by a good wagon road $31 / 2$ miles long.

The property was in charge of $\mathrm{Al}$ Borosky at the time of the visit. He reported that no work other than assessment work had been done on it for several years.

The property was opened by an inclined shaft 110 feet deep, now inaccessible, and a vertical shaft 247 feet deep, which at the time of visit was partly full of water and in the upper levels inaccessible because of bad air. Short drifts are reported to have been cut on the 100 and 150 foot levels.

The country rock is greenstone, probably a part of the Permian series exposed 2 miles to the south in the Baker quadrangle. The vein trends $\mathrm{N}$. $5^{\circ} \mathrm{W}$. and dips $80^{\circ} \mathrm{E}$. Where exposed in several trenches it attains a maximum thickness of 2 feet and consists of brecciated quartz, stained in part with hematite, jarosite, and malachite, the decomposition products of the primary pyrite and chalcopyrite, of which remnants occur in some specimens on the dumps. The vein is said to persist on the bottom levels and to be quite regular in the workings so far driven.

Some very high grade ore has been obtained in the upper workings of this mine, wire and sheet gold being rather common. Nothing is known of the average tenor of the ore, which must have been rather spotty, although Mr. Borosky states that assays of $\$ 10$ or $\$ 12$ in gold to the ton are not uncommon. A little silver is also reported.

\section{GRUII}

Andy Grull has done considerable work in developing a prospect in the gulch southeast of the Twin Baby mine, in sec. 20, T. 6 S., R. 42 E., about 2 miles northeast of Medical Springs.

The principal work, aside from trenches and shallow prospect shafts, has been done in a tunnel about 300 feet long, driven to cut a quartz vein that crops out on the hill north of the gulch. This tunnel exposes Teritary sediments, closely associated with an andesite flow, for about 200 feet, then continues in greenstone, which is highly siliceous and very hard. The vein that is the objective of 
the tunnel is supposed to lie about 70 feet ahead of the face of the drift. Mr. Grull reports no assays but very high grade pans of free gold from the vein.

The greenstone carries minute veinlets of chalcopyrite and pyrrhotite, with some scapolite (dipyre), epidote and andradite. Oxidation minerals include hematite, nontronite, gypsum, and limonite.

\section{OUTLOOK FOR THE DISTRICT}

The developments in the Medical Springs district in 1930 were not adequate to permit any estimate of its potential output. The cover of Tertiary rocks masks much of the possible mineralized area. More development work would have to be done and a better basis thus obtained for evaluation of the possibilities before mining would be justified.

\section{VIRTUE DISTRICT}

\section{GEOGRAPHY}

The Virtue district includes T. 9 S., R. 41 E., and immediately adjacent territory to the north and south. The district lies about 4 miles east of Baker, from which it is reached by an excellent highway. The Oregon Trail of pioneer days passed through the district by way of the pass just south of the Flagstaff mine.

The central topographic feature of the district is Virtue Flat, a wide, gently sloping, basinlike area, nearly surrounded by rolling hills. The district is drained by Ruckles Creek, which joins the lower Powder Valley at Keating. Altitudes in the district range from about 3,100 feet at the head of Ruckles Creek Canyon to 5,077 feet on the top of Lone Pine Mountain. The climate is very dry, and most of the land is utilized only for sheep range, but a few dry farms are situated in Virtue Flat.

\section{FIELD WORK}

The Virtue district is included in the Baker quadrangle, on the topographic map of which it was possible to indicate the principal geologic formations present. (See pl. 4.) About three weeks in June and July, 1930, was spent in mapping the areal geology and studying the mines.

\section{GEOLOGY}

\section{GENERAI FEATURES}

The oldest formation in the Virtue district is composed of argillite and chert, of Carboniferous age, which is exposed in the hills south of Virtue Flat and in a small area north of the fault forming the north boundary of the flat. Into this formation are intruded two 
igneous series-the earlier a gneissic gabbroic series accompanied by norite and amphibolite facies and a sodic quartz diorite; and the later a nearly massive biotite-quartz diorite.

There are no rocks present in the district to record the long interval between the intrusion of these rocks, probably in the Mesozoic era, and the outpouring of the Columbia River lava in Neocene time. An erosion surface of considerable relief, perhaps comparable to that of the present surface, was developed upon the pre-Tertiary rocks in this interval. The Columbia River lava and the fluviatile and lacustrine deposits interbedded with it almost completely surround the Virtue district and without doubt extended over the entire area before they were removed by erosion. Gravel terraces presumably of Quaternary age are developed in Virtue Flat across the edges of the fluviatile deposits. Presumably it was gravel correlative with these terraces that yielded the mammoth tooth mentioned by Lindgren. ${ }^{20}$

The structure of the argillite is complicated in detail, but its areal distribution in the Baker quadrangle is such as to indicate a dominantly eastward strike through the district. The Tertiary rocks in the vicinity of Lone Pine Mountain dip southwest, and north of Virtue Flat they dip northeast. Virtue Flat itself is in part of graben structure, bounded by northwestward-trending faults, but it is in major part due to erosion. There is, indeed, a possibility that the valley is in part an exhumed valley in the surface antedating the extrusion of the Columbia River lava.

\section{ORE DEPOSITS}

The ore deposits of the Virtue district are contained in quartz veins in the pre-Tertiary rocks. They were probably formed by emanations from the biotite-quartz diorite exposed south of the Flagstaff mine or from related masses at greater depth.

The veins consist of quartz, calcite, and scheelite, with a little sericite, and carry small amounts of pyrite and chalcopyrite and free gold. The veins are commonly brecciated, and the breccia zones are favored sites for the sulphides.

\section{THE MINES}

VIRTUE

Location.-The Virtue mine, which has given its name to the district and has hitherto been the greatest producer in it, is in sec. 21, T. 9 S., R. 41 E., at the foot of the hills bounding Virtue Flat on the south. It is about 3 miles south of the Baker-Robinette highway and about 12 miles by road from Baker.

${ }^{20}$ Lindgren, Waldemar, op. cit., p. 722. 


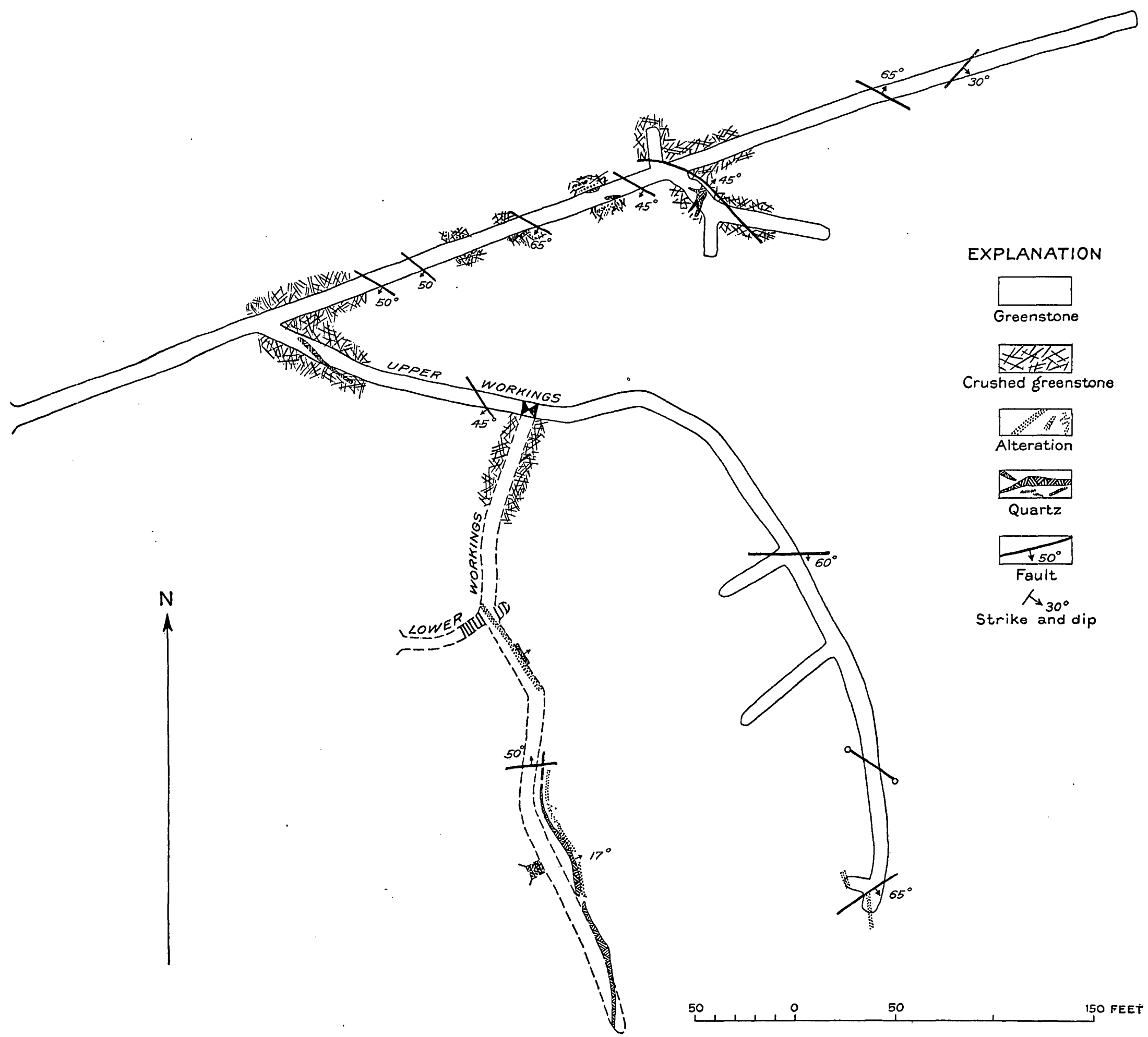




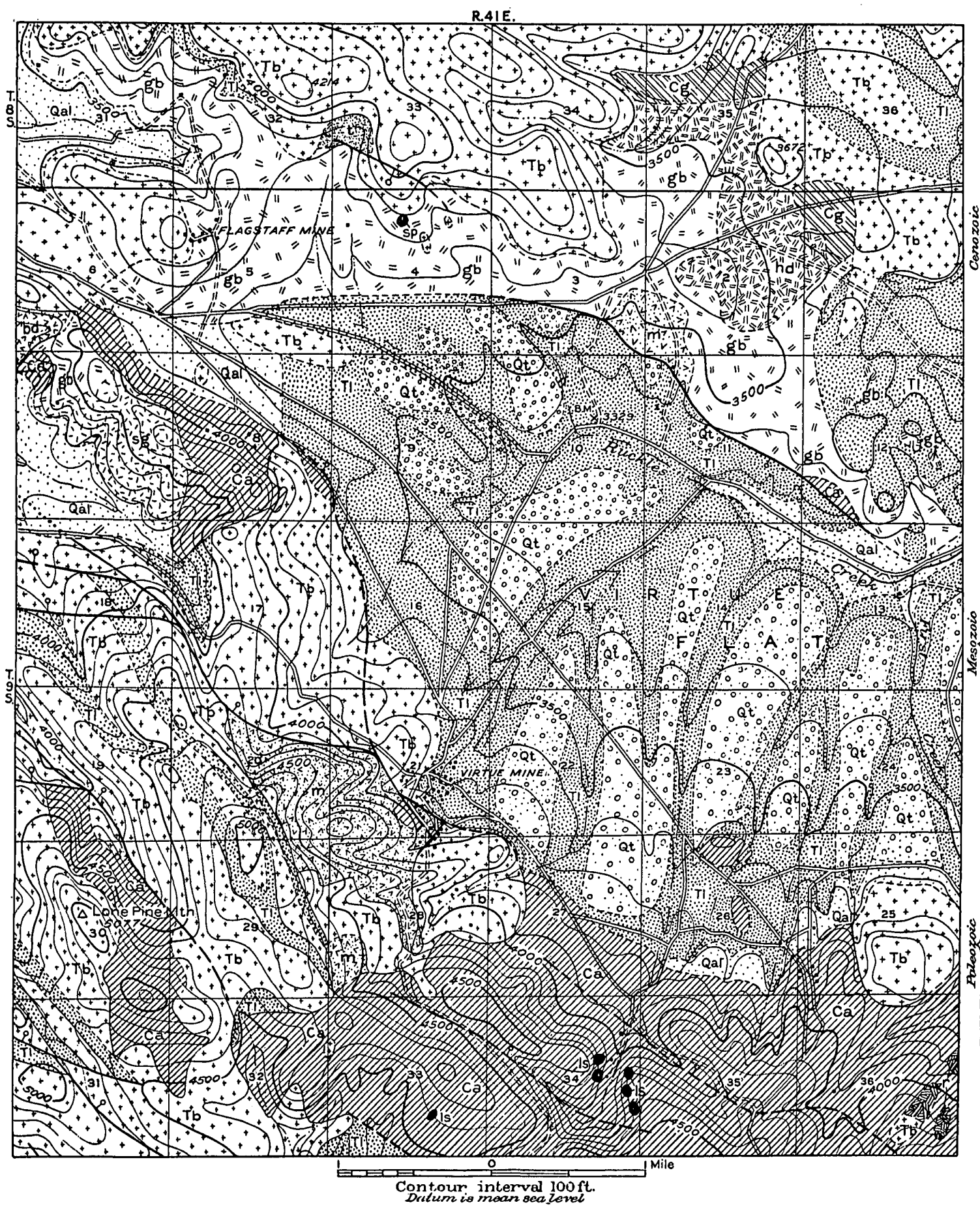

TOPOGRAPHIC AND GEOLOGIC MAP OF VIRTUE DISTRICT, BAKER COUNTY, OREG.

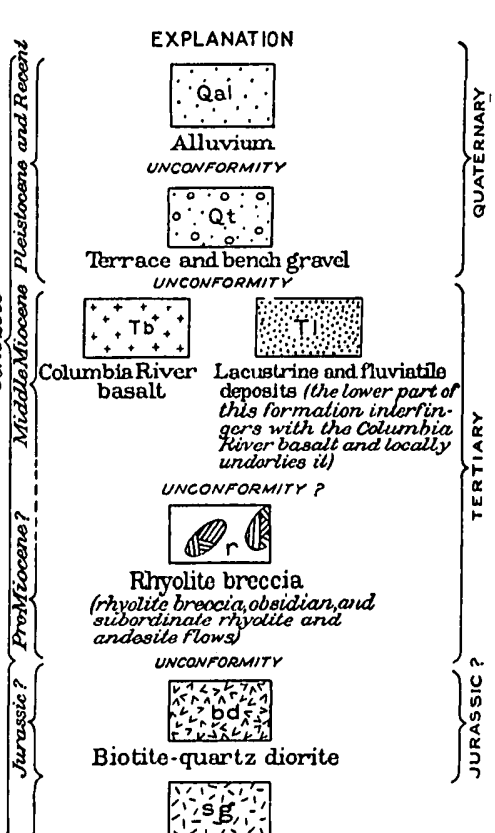

Silicified gabbro
(rasulting from igneous mata-
morphism of diorite and gabto)






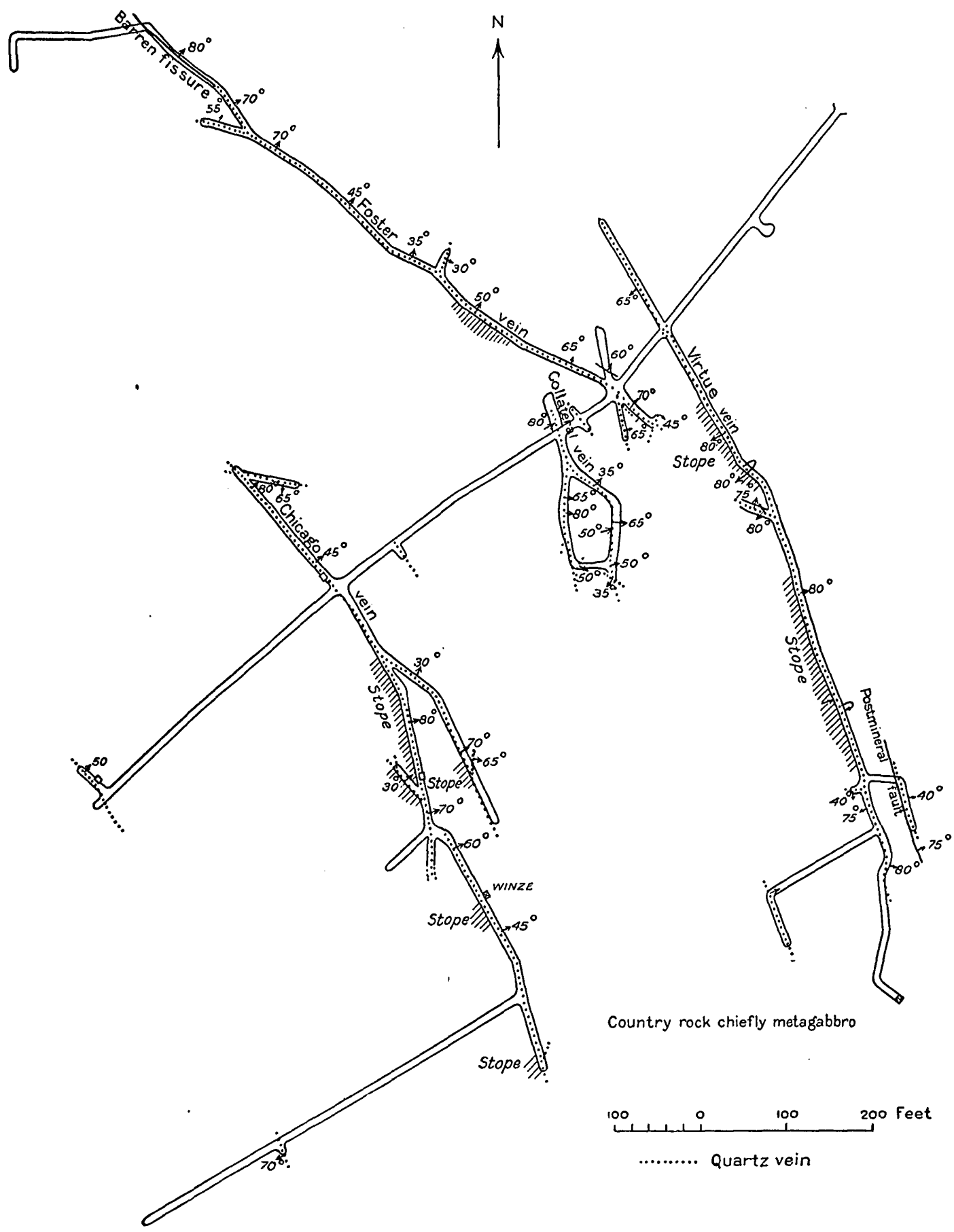

SKETCH MAP OF MILL-TUNNEL LEVEL OF VIRTUE MINE, VIRTUE DISTRICT, OREG. 


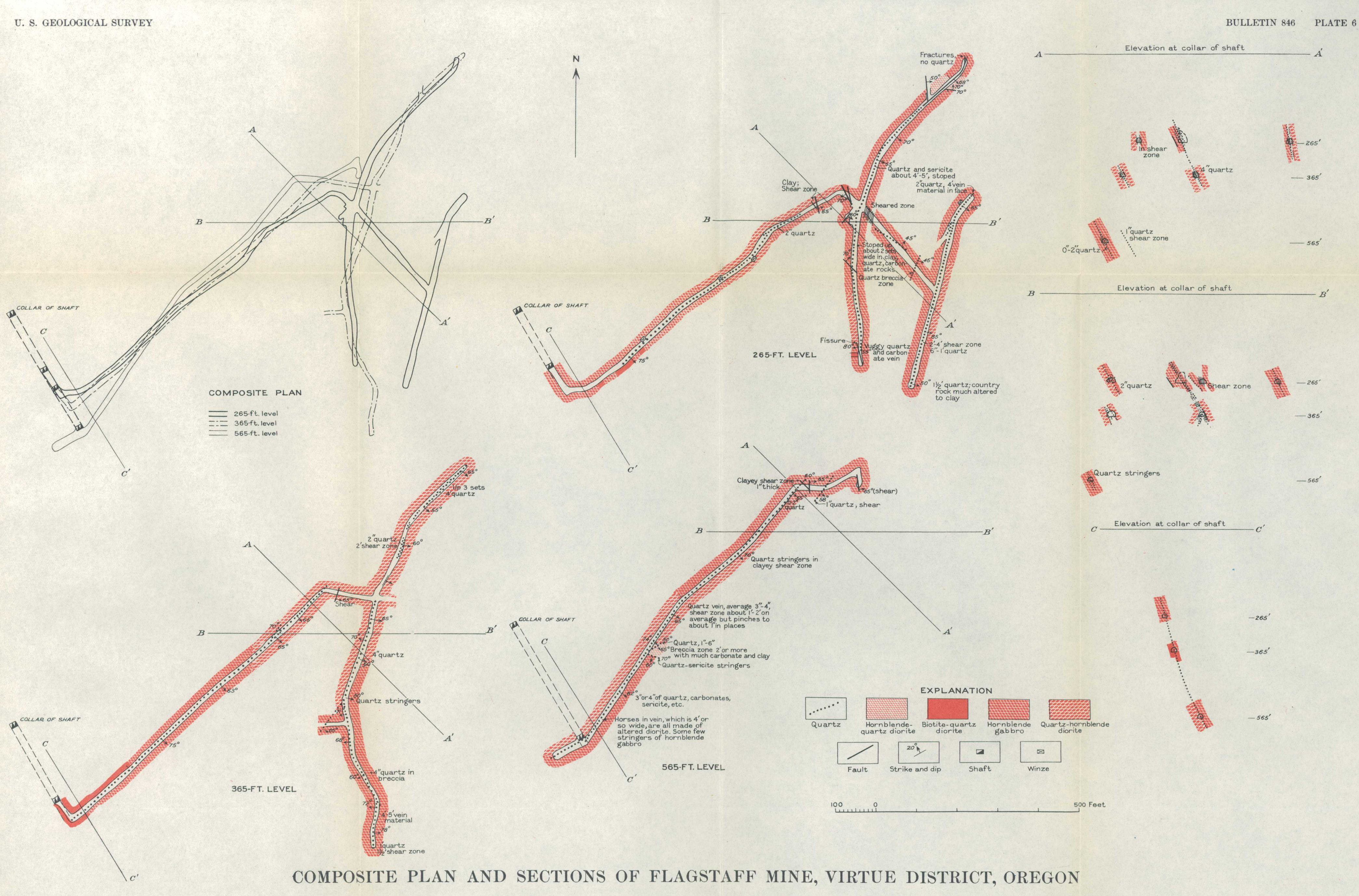


History and production.-The deposit at the Virtue mine, according to Lindgren, ${ }^{21}$ was discovered in 1862 by tracing up the rich placers in the gulch below. For the next 10 years it was known as the Rucker or Union mine and was very actively worked. Between 1871 and 1878 it was worked almost continuously, largely by Brown \& Virtue. In 1878 it was sold to Grayson \& Co., of San Francisco, who worked it in a more or less satisfactory way till 1884. It was then idle until 1893, when work was resumed and continued until 1898 with excellent results. After a short period of idleness the mine was sold to the Consolidated Virtue Mine Co., of Montreal, Canada, which also owned the adjoining Collateral mine. The upper parts of the mine were worked for a short time, and the mine was again closed August 1, 1899. The property was worked for a brief interval in 1906-1908, when a little ore was extracted from above the drainage level and about $\$ 1,500$ recovered from ore on the dump. ${ }^{22}$ In 1912 the mine was equipped electrically, but no production was made until 1919. A small production was also made in 1921, 1922, and 1924 by lessees, but nothing has been reported since. The total production has been about $\$ 2,200,000$.

At the time of this survey the mine was almost entirely inaccessible except for the mill-tunnel level and a few stopes above it, so that little can be added to the description of Lindgren.

Development.-The Virtue mine is developed by three tunnels, the lowest of which, the mill level, is about 300 feet below the outcrop. From the lowest tunnel a vertical shaft was sunk 800 feet, and crosscuts were made to the vein every 100 feet. The levels extend from 200 to 400 feet north of the shaft and 800 to 900 feet south from it. The development workings aggregate not less than 10,000 feet.

Geology.-The country rock is strongly sheared greenstone, highly chloritic and somewhat serpentinous. It was regarded by Lindgren ${ }^{23}$ as an altered volcanic tuff or breccia, and some of it is almost surely of this origin, but much of it is believed to be a sheared gabbro. Specimens collected in the crosscut on the mill level show all gradations between a chloritic schist, whose origin it would be impossible to determine from the specimen itself, to a brecciated and chloritized rock that is clearly derived from the brecciation of a gabbro. Accordingly, it is likely that some of the other rocks in the mine whose mottled schistose character at first suggests their origin as tuffs are of the same origin. It is clear that most of the rounded hill south of the mine is formed of sheared gabbro.

\footnotetext{
s1 Lindgren, Waldemar, op. cit., pp. 722-723.

22 Parks, F. M., and Swartley, A. M., op. cit., pp. 229-230. Also U. S. Geol. Survey Mineral Resources, 1908, pt. 1, pp. 526-527, 1909.

${ }^{23}$ Lindgren, Waldemar, op. cit., p. 723. $164495-33-6$
} 
Eight veins, of which the Virtue, Collateral, and Chicago are most productive, have been cut in the mine workings. The Chicago and Collateral were formerly the bases for independent mines, but all are now owned by one company. They are subparallel and strike N. $20^{\circ}-45^{\circ} \mathrm{W}$. They dip northeast above the mill level but steepen downward and dip southwest in the lower workings of the mine. (See pl. 5.) This suggests that they may owe their origin to torsion about a flat axis.

The veins range in thickness from 6 inches to 12 feet and average about 14 inches. They are filled with white coarsely crystalline quartz with subordinate calcite. Vugs are common. Free gold, coarse and partly crystalline, with the unusual fineness of 0.940 , is reported by Lindgren. ${ }^{24}$ The only sulphides observed were pyrite and chalcopyrite, both of which are sparingly present. The veins are locally brecciated and banded parallel to the walls, and these places are reported to have been richest. Veinlets of calcite, quartz, and pyrite occur in the country rock bordering the veins. Lindgren reports that the richest ore occurred near the surface. Average values of $\$ 20$ to the ton were obtained in 1870 , of $\$ 40$ in 1873 , of $\$ 24$ in 1875 , and from $\$ 15$ to $\$ 16$ between 1893 and 1898 .

The pay shoot is said to have been cut off between the seventh and eighth levels by a brecciated interval below which the vein was of very low grade. Warm water was encountered in the lower levels and stands in the shaft to a short distance below the mill level, considerably above the valley. This water was interpreted by Lindgren, doubtless correctly, as an ascending column of underground circulation. A fault just north of the mine (pl. 4) separates the Tertiary beds of Virtue Flat from the pre-Tertiary rocks to the southwest, and this fault may well have given access to the deeper levels appropriate to the temperature of the water. Gouge sealing the fault above the valley level may have impounded the water in the mine.

\section{FLAGSTAFF}

Location.-The Flagstaff mine, owned by J. L. Layden, is in sec. 5, T. 9 S., R. 41 E., on the crest of the divide between Virtue Flat and Baker Valley, at an altitude of 3,900 feet. It is less than half a mile from the Baker-Robinette highway and about 7 miles from Baker.

Development and production.-The mine was actively worked in the years preceding 1898 and has been developed by an inclined shaft 760 feet deep, with levels at 265,365 , and 565 feet. The workings aggregate about 6,000 feet. Since 1898 the only reported production

${ }^{24}$ Lindgren, Waldemar, op. cit., p. 724 . 
was in 1923; when a little bullion was recovered incidentally to development. The total production of the mine is probably not more than $\$ 100,000$.

Geology.-The country rock of the mine is chiefly coarse sheared gabbro and quartz-bearing hornblende diorite, both containing much actinolite and some epidote, cut by dikes of biotite-quartz diorite and hornblende-quartz diorite. The two major rocks appear to grade into each other, but in view of their petrographic differences this is probably due to later metamorphism rather than to an original heterogeneity of a single intrusive mass. (See pl. 6.)

The biotite-quartz diorite and hornblende-quartz diorite dikes have been recognized only in the mine workings, and exposures are insufficient to demonstrate their attitudes. They are cut by and are clearly older than the mineralized shear zones of the mine.

The ore deposit consists of several sheared and brecciated zones and veins. They range in strike from N. $45^{\circ} \mathrm{E}$. to north and dip steeply, averaging $65^{\circ}$, either east or west.

The faults and veins are arranged in a frayed pattern. The main vein, in whose footwall the incline is sunk, flattens from a dip of about $75^{\circ}$ in the upper workings to about $55^{\circ}$ on the 565-foot level. The drifts on the three levels from this shaft trend successively more northward on the lower levels, although they start on what is almost certainly the same vein at the shaft. Inasmuch as the dips of these principal veins are all southeastward, the necessary result of this arrangement is that a number of branch veins must join the main vein, as is shown by the map and more clearly by the sections of the mine. (See pl. 6.) Unfortunately the raises and manways of the mine were all inaccessible because of defective timbers, so that it was impossible to tie one level to another except at the main shaft. The "horsetail " arrangement of the veins suggests torsion about a steeply inclined axis.

The faults through the gabbro and diorite are all accompanied by great masses of clay gouge. Some of this gouge is probably due to comminution of the country rock by friction, but most of it is hydrothermal rather than mechanical in origin, as is shown by the association of zeolites with the clays.

Within these masses of gouge are extremely irregular brecciated lenses of quartz. These lenses locally range from a knife-edge to more than a foot in thickness in a few feet of strike length. The maximum thickness of quartz observed in any one stringer was $11 / 2$ feet, although in one place, where the shear zone is over 20 feet wide, several lenses whose aggregate thickness is about 4 feet are present. The shear zones themselves are irregular; they probably average abolit 3 feet in thickness. 
Locally the quartz is massive and coarsely crystalline, elsewhere ruggy, and elsewhere sheeted and brecciated. Gold is present in the quartz but, according to Mr. Layden, occurs also in the gouge, though in less amount. No sulphides were observed during this survey, but tetrahedrite and stibnite, as well as the tungsten mineral scheelite, have been recorded from the mine by Lindgren. ${ }^{25}$

The principal minerals of the altered rock are a clay mineral of low refringence and birefringence, sericite, calcite, serpentine, and a zeolite related to chabazite. Locally the wall rock is silicified, but more commonly it is altered to clay.

No assay samples were collected, but Lindgren reports average values of $\$ 16$ to the ton in the quartz. According to Mr. Layden, large quantities of the gougelike material will assay $\$ 5$ to the ton. The largest stopes in the mine occur at the junctions of fissures. Here the shear zones are wider and commonly have more quartz, with higher gold assays.

The lowest accessible level, the 560, is seemingly less well mineralized than the higher levels. The exposed shear zones are narrower and carry less quartz. Mr. Layden believes that the future of the property is dependent on large-scale mining of the gougelike material with its relatively low gold assays of $\$ 5$ to the ton. There is no doubt that large quantities of this material are available.

The water level in the mine is just below the 560 level, about 420 feet vertically below the outcrop and not far above the level of Baker Valley.

\section{KOEHLER}

The Koehler mine is on the west slope of the range of hills lying south of the Flagstaff mine. The workings were inaccessible at the time of this survey. According to Parks and Swartley, ${ }^{26}$ the mine yielded antimony and gold, beginning late in 1915. The vein is reported to be well defined, with a maximum width of about 10 feet. Stibnite is distributed through the whole width of the vein, but massive stibnite occurred near the hanging: wall in lenses that were 2 feet thick. Some of these lenses yielded ore that was shipped direct; other ore was brought up to grade by sorting. Several carloads carrying over 50 per cent of antimony were shipped, and the receipts from these sales are reported to have been about $\$ 15,000$.

\section{NORWOOD}

The Norwood mine, in sec. 8, T. 9 S., R. 41 E., about 2 miles north of the Virtue, was caved and inaccessible in 1930. The property has been described ${ }^{27}$ as embracing two lode claims. The country

${ }^{26}$ Lindgren, Waldemar, op. cit., p. 725.

26 Parks, H. M., and Swartley, A. M., op. cit., p. 137.

${ }^{27}$ Idem, p. 174. 
rock is greenstone cut by several quartz and calcite veins, mostly rather small, and shows considerable postmineral brecciation. The largest vein dips steeply, strikes west, and consists of quartz gouge and country rock. Along 450 feet of strike the vein averages about 2 feet in width. A small mill was installed in 1913, but no production has been reported. Little work has been done for many years at this property.

\section{CIIFF}

The Cliff mine is about three quarters of a mile north of the Flagstaff, on the north side of a small gulch draining into Baker Valley. In 1930 the mine had been long abandoned and the shaft was inaccessible. The following account is summarized from the reports by Lindgren ${ }^{28}$ and by Parks and Swartley, ${ }^{29}$ with some observations of surface geology by the writers.

The country rock of the mine is sheared gabbro. The vein strikes north and consists of 1 to 3 feet of quartz with a little calcite in altered gabbro. Scheelite was identified in the quartz 30 years ago by C. L. King, of Baker. The property is developed by a 300 -foot vertical shaft. In 1916 the war prices of tungsten induced F. S. Baillie and later W. E. King to reopen the long-abandoned mine in the endeavor to exploit the scheelite, but nothing came of the attempt.

\section{WHITE SWAN}

Location.-The White Swan mine is at the foot of the hills south of Virtue Flat, in sec. 25, T. 9 S., R. 41 E. It is about 5 miles from the Baker-Richland highway and about 14 miles from Baker by road.

Development and production.-According to Lindgren, ${ }^{30}$ the White Swan deposit was discovered in the early days by following up the rich placers of the gulch below. The mine was vigorously operated about 1890 but was closed in 1897 . It was reopened about 1900 and operated by Letson Balliet until 1903, when it was again closed..1 Lindgren estimated the total production at not less than $\$ 200,000$, on the basis of mint reports of output in 1891 as $\$ 72,000$ and in 1892 as $\$ 72,642$.

In 1930 the mine was being reopened by a Washington syndicate, with E. McNaughton as manager. At the time of visit very little of the old workings was accessible, however.

The mine was developed by a nearly vertical shaft 300 feet deep from which four levels were turned. About 2,000 feet of development work has been done.

\footnotetext{
is Lindgren, Waldemar, op. cit., p. 725.

Farks, H. M., and Swartley, A. M., op. cit., p. 56.

${ }^{\text {so }}$ Lindgren, Waldemar, op. cit., p. 725 .

31 Swartley, A. M., op. cit., p. 131.
} 
Geology:-The country rock consists of dark carbonaceous argillite with interbedded layers of chert and greenstone. The greenstone represents altered volcanic sediments. Intrusive into this argillite formation are several narrow dikes of diorite porphyry. The general strike of the formation is westward.

Several narrow veins are exposed in the vicinity of the mine. All trend generally west, but there is no consistent parallelism observable, although most dip steeply south. The exposed veins reach thicknesses of 1 to $1 \frac{1}{2}$ feet, but more common widths are a few inches. No information is available regarding the thickness of the White Swan vein in the old workings.

The only minerals observed in the veins were quartz, sericite, and calcite, with a little limonite to attest the former presence of sulphides, which however, must have been sparse.

\section{CHICAGO-VIRTUE}

The Chicago-Virtue mine, locally called the Barry property, is in sec. 35, T. 9 S., R. 41 E., just south of Virtue Flat. The property was idle in 1930, and apparently little work had been done there for many years.

The property has been developed by a steeply inclined shaft 86 feet deep, from which a short drift has been run 30 feet below the collar and a crosscut and drift aggregating 250 feet at the bottom of the shaft. No production has been reported from the property.

The country rock is cherty argillite. The work has been directed to the development of a vein that strikes east and dips $65^{\circ} \mathrm{S}$. The vein contains quartz, locally vuggy, elsewhere brecciated, which ranges in thickness from a knife-edge to almost a foot. The vein follows a slickensided surface. Nothing is known of the assay value. of this quartz.

\section{CARROLI B.}

The Carroll B. property consists of 10 claims in the SE. $1 / 4$ sec. 3, T. i0 S., R. 41 E., which are controlled by Samuel J. Niblack. Development consists of a shaft, from which at least one drift, which is partly accessible, has been turned, and two adits, each several hundred feet long, on other parts of the property. The predominant country rock is greenstone with some gabbro and cherty argillite. The quartz vein on which the most work has been done is 1 to 2 feet thick where exposed in the drift near the shaft. Nothing was observed in the other two adits but the greenstone country rock.

BRAZOS

The Brazos mine, in sec. 11, T. 10 S., R. 41 E., was inaccessible in 1930. It has been described by Lindgren. ${ }^{32}$ Since his visit consider-

82 Lindgren, Waldemar, op. cit., p. 726. 
able work has been done on the property, including the sinking of a 600 -foot shaft and driving several drifts, ${ }^{33}$ but for many years prior to 1930 the mine had been inactive.

\section{OTHER PROSPECTS}

The hills on all sides of Virtue Flat are studded with dumps of prospect pits attesting the widespread mineralization of the area. Most of these workings date back many years, and none have been productive.

North of Virtue Flat the Columbia-Friday vein has been developed in several shallow inclined shafts. This vein follows the fault contact between Tertiary sediments and argillite for a short distance. All the workings were inaccessible in 1930.

A great many prospects have been worked on the hill south of the Flagstaff mine. The country rock is chiefly argillite, but some work has been done in the gabbro and quartz diorite also.

There are many small prospect adits and pits on the southern slope of the ridge that lies between Virtue Flat and the depression in which flow Sutton and Alder Creeks. Much of the underground work is inaccessible.

Three adits, each several hundred feet long, in the SW. $1 / 4$ sec. 2, T. 10 S., R. 41 E., were examined. The country rock is cherty argillite, the average strike of which is about $\mathrm{N} .75^{\circ} \mathrm{E}$. and the dip $75^{\circ}$ SE. A few thin and irregular quartz veins striking east and dipping $45^{\circ} \mathrm{S}$. are encountered by the adits. The maximum thickness of the veins observed was 2 feet. In many places the argillite is sheared, and considerable thicknesses of clay gouge are developed.

\section{OUTLOOK FOR THE DISTRICT}

Among the districts described in this bulletin, the Virtue district seems to be one of more than usual promise. This statement is based not only on the production record of the Virtue mine but also on the fact that both in this mine and the Flagstaff the veins are persistent. This persistence contrasts with the irregularity of the veins common to most of the other districts. If the mineralization has been adequate the persistence of these veins and shear zones is highly favorable to mining on a larger scale than would be warranted in the thinner though perhaps richer veins found in several other districts. Another favorable factor is the relative accessibility of the district.

These statements should not be interpreted as directly commendatory of any single property nor as excluding the possibility of the veins becoming irregular or lensing out at depths, but if assays

${ }^{33}$ Parks, H. M., and Swartley, A. M., op. cit., p. 43. 
show workable ore in these veins, the likelihood of their workability over a considerable area and in depth is somewhat greater than that of the veins in most of the other districts here described.

\section{BAKER DISTRICT}

\section{GEOGRAPHY}

The Pocahontas, Auburn, and Minersville districts are now known collectively as the Baker district. The present survey was concerned only with the part of the district that lies within the Baker quadrangle, which is made up of the southeast end of Elkhorn Ridge, in Ts. 9 and 10 S., R. 39 E., and the eastern half-mile strip of Ts. 9 and $10 \mathrm{~S}$., R. $38 \mathrm{E}$. The drainage to the northeast goes through Marble Creek and the tributaries of Salmon Creek-Hibbard, Rouen, Dutch, and Washington Gulches. The drainage to the east goes through Griffin and Elk Creeks, and that to the south through California Gulch, Blue Canyon, French Gulch, and Poker Creek. All these streams empty into the Powder River, which swings around the south end of Elkhorn Ridge. Altitudes range from about 4,500 to about 7,000 feet, but the ridge is considerably higher a few miles farther northwest. The district is for the most part covered with pine forest. Its different parts are readily accessible by roads from Baker. There is a road in nearly every gulch, and several of them reach the altitude of the Auburn Ditch, which traverses the district at about the 5,300-foot contour. The northern part of the region described is generally called the Pocahontas district and the southeastern part the Auburn district, after the old placer town.

\section{GEOLOGY}

Dark-gray cherty argillite is the oldest rock in the district. Here and there in the thick cherty series occur pod-shaped lenses of limestone, generally a few hundred feet long. Interbedded in this sedimentary series but subordinate to the chert are strata of lava and pyroclastic material which now form greenstone. Subordinate shaly beds also occur. Most of the chert is massive, so that no indication of structure is present, but some exposures display a distinct highly crumpled and contorted bedding.

From the few observations that could be made the average strike of the formation may be about N. $80^{\circ} \mathrm{E}$. The dips are uniformly steep and incline more commonly southeast than northwest. The age of this formation is in doubt, but from a few poor collections of fossils it is referred by G. H. Girty to the Carboniferous, probably Mississippian.

The argillite series has been intruded by gabbro and related rocks, which now occupy a considerable proportion of the area. The intru- 
sive masses have very irregular outlines, so that no structural control of intrusion is apparent, although there is a possibility that some are sills. The basic rocks are sheared and altered, some of them to such an extent that the product can not be distinguished with certainty from the greenstone that belongs in the older sedimentary series.

The argillite series and the gabbro and related rocks are intruded by numerous light-colored porphyritic dikes, which upon the evidence of thin sections are classed as granophyre. Some are between 50 and 100 feet thick, but most of them are about 15 or 20 feet thick, and a few are less than 1 foot thick. These dikes may be related to the quartz diorite masses which occur commonly in eastern Oregon and representatives of which are found a few miles to the northwest and also a few miles to the south.

The southern and eastern limits of the district are marked by the edges of the overlapping Columbia River lava flows, with their interbedded lake and stream sediments and tuffaceous deposits. The Tertiary rocks are mildly disturbed as compared with the older rocks. In the Tertiary rocks a system of northwestward-trending faults is apparent which can not be seen in the pre-Tertiary terrane but which no doubt cut it also.

The district is bounded on the north by a major normal fault, downthrown to the north, which trends about N. $80^{\circ} \mathrm{W}$. The latest movement along this fault has probably been as late as Pleistocene, or possibly Recent. North of the fault lies the broad, level, downthrown Baker Valley at an altitude of about 3,400 feet.

\section{ORE DEPOSITS}

The Baker district has been practically inactive for many years, and most of the old mines and prospects were inaccessible at the time of this survey. Much of the following information has, therefore, been taken from the earlier reports of Lindgren, Swartley, and Parks and Swartley. Lindgren ${ }^{84}$ says:

Though *** nearly every creek and gulch heading in this part of the range has carried more or less placer gold and a few have been enormously rich, there is throughout a very marked absence of important vein systems to which the origin of these placers could be attributed. In part this may be due to insufficient prospecting, but in most cases I believe that the placer gold was here rather derived from small seams and veinlets than from prominent fissure veins.

THE MINES

TOM PAINE

The Tom Paine mine is in McCord Gulch, the first gulch west of Salmon Creek, in sec. 7, T. 9 S., R. 39 E. The property consists of

s Lindgren, Waldemar, The gold belt of the Blue Mountains of Oregon: U. S. Geol. Survey Twenty-second Ann. Rept., pt. 2, p. 650, 1901. 
one patented claim and is developed by several adits, all of which are caved and inaccessible except one, about 55 feet below the main level. A raise to the surface is open for about 30 feet above the lower adit. It is reported that the Tom Paine vein produced $\$ 70,000$ worth of coarse gold from a small pocket about 1884. The country rock is limestone and argillite. Swartley ${ }^{35}$ speaks of the company as the Yellowstone Mining Co. and mentions two veins on the property, the Tom Paine and the Old Soldier. He reports the Tom Paine vein to range in width from several inches to several feet and the Old Soldier to be 3 feet wide. The only observation that could be made on the vein in 1930 was in the 30 -foot raise from the lower level just mentioned, where it consists of 18 inches of quartz and sericite with 2 or 3 inches of gouge on both hanging and foot walls. The vein strikes N. $20^{\circ}$ E. and dips $40^{\circ} \mathrm{W}$. The hanging wall is limestone that contains numerous small cubes of pyrite partly altered to limonite. The limestone strikes N. $55^{\circ} \mathrm{E}$. and dips $60^{\circ} \mathrm{SE}$.

A short distance west of the Tom Paine mine and a little farther upstream Mr. Lilley and one other man have recently exposed in a 30 -foot adit a small 6 -inch vein of quartz and sericite. The country rock is crushed argillite.

\section{OLD SOLDIER}

The Old Soldier claim lies east of the Tom Paine and a short distance downstream from it. The workings are all inaccessible.

\section{MARBLE CREER MINING \& MILIING CO.}

The claims of the Marble Creek Mining \& Milling Co. lie between McCord Gulch and Marble Creek. The property is opened by several thousand feet of drifts, most of which were inaccessible. No production has been reported.

The country rock is crushed and altered gabbro in which the workings expose an irregular shear zone. A few irregular patches of quartz were seen and some specks of bornite with a little copper stain.

\section{XELLOW BOY MINING CO.}

The Yellow Boy Mining Co. controls nine claims, three of which are patented, just south of the Nelson placer, in sec. 8, T. 9 S., R. $39 \mathrm{E}$. The president of the company is N. A. Muegge, and the secretary is F. C. McColloch, both of Baker. The property is developed by two adits-the older, upper one several hundred feet long, including a 50-foot incline, and the lower one about 450 feet long.

${ }^{85}$ Swartley, A. M., Ore deposits of northeastern Oregon: Mineral Resources of Oregon, vol. 1 , No. 8, p. 162, Oregon Bur. Mines and Geology, December, 1914. 
The country rock is greenstone. At the face the upper adit cuts a dike, probably one of the granophyre dikes so common in the region. A few quartz stringers show in the adits.

\section{STUB}

The Stub or Kent mine, owned by George and Chester Gardener, lies in sec. 20, T. 9 S., R. 39 E., near the head of Washington Gulch. The property is opened by an adit, which is now caved about 150 feet from the portal but which, according to Swartley, ${ }^{36}$ is several hundred feet long and has a short winze and some raises turned from it. Swartley states that a test run made in 1914 is reported to have returned $\$ 1,140$ from 140 tons of ore. No other production has been reported.

The country rock is siliceous argillite. The adit encounters a shear zone, striking $\mathrm{N} .65^{\circ} \mathrm{W}$. and dipping steeply southwest, about 100 feet from the portal. According to William Dale, this is not the main Stub vein, and Swartley ${ }^{37}$ says:

The vein has a north-northeast strike and a nearly vertical dip, with but a few inches of quartz to several feet of broken rock.

\section{SORBECK}

The Sorbeck brothers, of Baker, own 170 acres of patented land in sec. 27 , T. 9 S., R. 39 E., on which several adits several thousand feet in total length have been driven. The predominant country rock is greenstone, but there also occur some gabbro and a little limestone. No veins have been found in any of these tunnels.

DALE

William Dale controls several claims in sec. 22 , T. 9 S., R. 39 E., which are opened by several small adits and numerous prospect pits. The predominant country rock is gabbro. One of the pits exposed a 3-inch quartz seam in which a few flakes of native gold were seen.

\section{PLACER MINES}

At the time of this survey all the placers in the Baker district vere inactive. The following report on the placer mines is quoted from Lindgren : $:$ s

Nearly every gulch of the south end of Elkhorn Range has been worked on a more or less extensive scale for placer gold, though few localities have been cxceedingly rich. Though the bu'k of the gold was extracted shortly after the discovery, in 1862, some work is yet going on at several of the old diggings, showing that the gravels are not yet exhausted.

\footnotetext{
${ }^{80}$ Swartley, A. M., op. cit., p. 163.

${ }^{37}$ Idem, p. 162.

ss Lindgren, Waldemar, The gold belt of the Blue Mountains of Oregon: U. S. Geol. Survey Twenty-second Ann. Rept., pt. 2, pp. 652-654, 1902.
} 
At the northern end of the eastern slope small placers have been worked on Marble Creek, near the limekiln. On Salmon Creek the placors are of much greater importance. This creek was worked with success for about 1 mile upward from the mouth of the canyon. The gravels were 4 to 10 feet deep and covered by 10 to 15 feet of an exceedingly fine, brilliantly white kaolinic material. ${ }^{39}$ The bottom of the canyon was originally filled with deposits to a width of 100 or 200 feet. Working downstream, the placer miners at the mouth of the canyon gradually discovered a very remarkable deposit, called the Nelson placers. These have been worked successfully for 30 years by the hydraulic process and are by no means yet exhausted. The working season extends from April to September, 1,000 miner's inches of water being used. The yearly production has generally been from $\$ 20,000$ to $\$ 30,000$. In the Mint reports for 1889 the production is given as $\$ 77,000$; in $1890, \$ 19,000$. The total production is believed to be over $\$ 400,000$. For one period of six years the production is said to have reached $\$ 214,000$. As the available grade is small, it is proposed to use a hydraulic elevator for mining below the level of the permanent sluice.

The mouth of Salmon Creek Canyon is marked by a low spreading débris fan. The Nelson placers are working the gravels of this fan in a pit covering 40 to 50 acres and from 20 to 100 feet deep. At the top of the bank the elevation is 3,750 feet. The gravel is subangular, many fragments reaching 1 foot in diameter, and consists of argillite and diorite, very little quartz being present. There are two layers. The upper stratum has a bluish-gray color, is 10 to 20 feet thick, and contains, evenly distributed, most of the gold. The lower stratum is yellowish-brown and its rocks are decomposed. This also contains gold, though in lesser amount, and its bottom has never been reached. Covering the top layer, near the mouth of the canyon, is the same white kaolin which covers the gravels of the creek. The gold, which is worth only $\$ 14$ to $\$ 16$ per ounce, is ordinarily fine, though nuggets up to $\$ 10$ in value occur. To the rough pieces quartz sometimes adheres.

Most interesting are the relations immediately at the mouth of the canyon, for here the hydraulic work has disclosed the presence of a continuous fault scarp 100 feet high and dipping $40^{\circ} \mathrm{F}$. It is smooth now, but when first exposed it is said to have been almost polished and in places covered with a clayey gouge. The direction is northwesterly, but with occasional bends and bulges. The exposed fault line extends completely across Salmon Creek for a distance of 1,500 feet, and the same line, less well exposed, is seen in the Baisley diggings, one-fourth of a mile northward, and in the Carpenter placers, half a mile southeasterly.

A shaft has been sunk in the bottom of the hydraulic pit near the foot of the scarp, but no bedrock was found at a depth of 90 feet. A minimum vertical throw of 200 feet is here shown, the valley side having sunk relatively to the mountains. The upper blue gravel probably was accumulated during the glacial epoch, while the lower dark-brown gravel is more likely to antedate that time; whether any very recent movement has taken place could not be decided.

Small placers have been worked in Washington Gulch, and the same applies to Griffin Creek and Elk Creek. The Griffin Creek placers are the oldest in eastern Oregon, having been discovered in the fall of 1861. The workings are 6 miles southwest of Baker City and at an elevation of 4,750 feet, above where

30 Microscopic examination of this "white kaolinic material" by the writers reveals the fact that it is not clay but fine volcanic ash, similar to that in the Sumpter quadrangle described by Pardee and Hewett.-J. G. 
the creek enters the lava hills. Some work was in progress in 1900 . On the divide between Griffin and Washington Creeks is a small area of high gravels which is said to contain gold in paying amount.

Most important were the placers of Auburn, in Blue Canyon, a tributary of Powder River. The diggings were discovered in 1862, and in a short time a town of several thousand inhabitants had grown up. For many years Auburn was the most prominent place in eastern Oregon, but the gold yield gradually diminished, and the camp was given over to the Chinese. At the present time hydraulic mining is carried on by two or three white companies. The total production of Auburn is difficult to determine, but it did not nearly reach that of Canyon, and the richest placers were soon exhausted. A small and rather steady production is maintained. The mint reports give $\$ 12,000$ for 1889 , $\$ 2,600$ for $1890, \$ 8,900$ for $1891, \$ 3,000$ for 1892 . The important Auburn ditch was completed in 1863. It takes water from the head of Pine Creek and other watercourses and carries it down to Auburn, a distance of over 30 miles; its capacity is 1,000 miner's inches.

Auburn is located in a wide basinlike valley at an elevation of about 4,000 feet. The argillites of the mountains here dip below the lava floods of the foothills. On both sides of the town the lava reaches up to elevations of 4,500 feet. The lavas cover soft, clayey, and loamy lake beds containing some coaly layers and impressions of deciduous leaves. On top of the eroded lake beds in the wide gulch rest subangular gravels 8 to 15 feet thick; the latter have been washed both in the gulches and on the flats. Near the town the depth to bedrock is not great, but farther down the valley the thickness of the sediments increases rapidly. The gravels are thus later than the lavas and have accumulated during the erosion of the present valley.

West of Auburn, on the road to Sumpter, several gulches with old placers are passed, Poker Gulch and California Gulch being next to Blue Canyon.

\section{OUTLOOK FOR THE DISTRICT}

The conclusion of Lindgren that the placer gold so widely distributed in this district has been derived from numerous small seams and veinlets rather than from persistent vein systems seems justified. The quartz veinlets so far found seem to be irregular, thin, and discontinuous; the fracturing of the rocks upon which these veinlets are dependent is characterized by its nonpersistence and irregularity. The mineralization has been widespread, beyond doubt, as is shown by the occurrence of placer gold in practically every creek draining the district, and it is entirely possible that pocket mining on a small scale may prove profitable, but the outlook for largescale mining seems unfavorable.

\section{QUARTZBURG DISTRICT}

\section{GEOGRAPHY}

The Quartzburg district is in Grant County. It covers much of the south slope of the divide between the main John Day River and its Middle Fork between Prairie City and Dixie Butte and extends north of the divide to embrace the headwaters of Ruby Creek. Altitudes within the district range from about 3,500 feet at Prairie City to 7,400 feet at the top of Dixie Butte. Most of the district is 
drained by Dixie Creek, which joins the John Day River at Prairie City, but Dads Creek and Ruby Creek drain parts of it.

The district is reached by way of Prairie City, the terminus of the narrow-gage Sumpter Valley Railway, which meets the through line of the Union Pacific system at Baker, 80 miles away. Prairie City lies on the John Day Highway, an excellent automobile road joining Ontario, on the Snake River, with Arlington, in the Columbia Valley. The former post office of Comer, about 6 miles north of Prairie City at the forks of Dixie Creek, has long since been abandoned.

Heavy woods clothe most of the hillsides in the district, and much of it is embraced in the Whitman National Forest.

\section{GEOLOGY}

\section{GENERAI FEATURES}

No topographic base maps of the Quartzburg district were available, and owing to the heavy forest cover of most of the district it was impossible, in the available time, to prepare a base map adequate to represent the evidently complex geology. Accordingly, the detailed geologic observations made during the writers' visit were limited to the areas within and immediately adjacent to the accessible mines, and only cursory examination was made of the intervening areas.

These observations, however, were sufficient to permit the statement that the dominant rocks of the district are meta-andesite, metadiabase, and related volcanic rocks, including tuff, associated with which are small amounts of argillite. The correlation of these old sedimentary rocks must await detailed mapping, although the writers' impressions are favorable to Lindgren's correlation of them with the Carboniferous argillite series of Elkhorn Ridge. ${ }^{40}$

Intrusive into this series of volcanic and sedimentary rocks, and doubtless in large degree the cause of their intense alteration, is a considerable variety of plutonic rocks, among which gabbro, serpentine, and diorite are most prominent. Dikes of diorite porphyry, albitized diorite, and metadiabase are associated with these plutonic rocks and are probably comagmatic with them.

Most of these rocks are considerably sheared and altered-the volcanic rocks by the development of biotite and tourmaline, the intrusive rocks by the development of talc, biotite, uralite, and tourmaline. Some of these alterations may have occurred during the later stages of consolidation of the basic intrusive rocks themselves. Others, however, seem to be attributable to a group of later intrusions. represented by small stocks of quartz diorite and granodiorite that

${ }^{40}$ Lindgren, Waldemar, op. cit., pl. 64. 
occur in the valley of Dixie Creek below the forks and near the head of Ruby Creek. The numerous dikes of quartz diorite porphyry, granodiorite porphyry, and quartz monzonite porphyry that occur in many places through the district may attest a much wider distribution of these silicic rocks at depth.

These quartzose rocks are practically free from crushing and are relatively unaltered. For these reasons they are believed to be younger than the basic intrusive rocks of the district. The age of these intrusive rocks is not accurately known from local evidence, beyond the fact that they are all definitely pre-Miocene. In the Strawberry Range, across the John Day River to the south, Jurassic rocks are intruded by quartz diorite. ${ }^{41}$ This supports Lindgren's assignment of the intrusions to a post-Jurassic age. The basic intrusions may be older than this, however. The pre-Miocene age of all the intrusions is fixed by the fact that the Columbia River lava, of Miocene age, rests on an eroded surface cut across all the plutonic rocks. Lindgren ${ }^{42}$ believed the intrusive rocks to be of early Cretaceous age.

The Columbia River lavas crop out along the north side of the valley of the South Fork of the John Day River at Prairie City and apparently completely surround the mineralized area of the Quartzburg district. They have, however, been removed by erosion from the mineralized area itself, most of which, if not all, must once have been covered by them. No study was made of the details of the geology of the Columbia River lava, as the formation has no bearing on the geology of the mines.

Although the regional distribution of the rocks of eastern Oregon strongly suggest an eastward strike as dominating the structure of the pre-Tertiary rocks, few observations were made on the structure of the stratified rocks within the Quartzburg district. The local structure is accordingly uncertain. Observations were sufficient, however, to permit the statement that the dominant structural features of the district are those imposed by the igneous intrusions.

\section{ORE DEPOSITS}

Two types of ore deposits have been recognized in the districtquartz-carbonate-sulphide fissure veins and a quartz-tourmalinechalcopyrite replacement body. The fissure veins are valuable chiefly for their gold, although small amounts of copper and cobalt have been won from them; the replacement body has its potential value in copper. Mineralization has occurred in nearly all the pre-Tertiary rocks. Although the observations within the district

¿1 Lupher, R. L., oral communication, 1929.

L Lindgren, Waldemar, op. cit., p. 596. 
were not thorough enough to be conclusive, the ore deposits are probably derived from the quartz diorite intrusions.

The veins consist of quartz, ferriferous dolomite, and calcite as the chief gangue minerals and carry the metallic minerals, pyrite, arsenopyrite, glaucodot, cobaltite, native bismuth, bismuthinite, tetrahedrite, pyrrhotite, chalcopyrite, sphalerite, and galena. The pyrite and chalcopyrite are the most plentiful, but the cobaltiferous minerals glaucodot and cobaltite are found in several localities. Supergene minerals recognized include covellite and bornite, and the oxidation products malachite, jarosite, and limonite were seen.

The quartz-tourmaline replacement body carries disseminated chalcopyrite, pyrite, cobaltite, magnetite, hematite, bornite, and covellite.

\section{THE MINES}

\section{DIXIE MEADOWS}

Location.-The Dixie Meadows mine, owned by the Discon Mining Co., is in sec. 23, T. 11 S., R. 33 E., near the head of Ruby Creek, just north of the Dixie Creek divide. It is about 12 miles from Prairie City by wagon road. The property, at the time of visit, was in charge of R. C. Reese, of Prairie City. In July, 1930, development work was going forward under G. H. Kight, foreman.

History and production.-The mine was opened in 1900 by Messrs. Kight and Reese. A mill was built in 1903. Between 1903 and 1910 about 8,000 or 9,000 tons of ore averaging $\$ 8$ to the ton in gold was milled and about 350 tons of concentrates averaging about $\$ 50$ to the ton were shipped. The property was sold to L. Vogelstein \& Co., of New York, in 1910, and a development campaign, with no attempt at production, was carried on by them for the next two years. The property was then sold to A. D. Coulter, of Seattle, and later, by combination with the Independence claim and the Sylvanite property in southern Oregon, it passed into the hands of the present owners. No production has been made since 1910 except a small amount by lessees in 1912-1914. The total production of the mine has been less than $\$ 100,000$, according to Mr. Reese.

The mine is developed by two adits, the upper of which, called the Blacksmith level, is caved and no longer accessible. About 6,000 feet of work was done in this tunnel and connecting raises, winzes, and stopes. All the production of the mine has been made from this level. The lower tunnel, about 100 feet lower than the Blacksmith level, is about 1,200 feet long. About 700 feet of this tunnel is a crosscut to the vein and the remaining 500 feet is a drift on the vein southwestward toward the old higher workings.

Geology.-The country rock of the mine is a complex of greenstone, meta-andesite, tuff, metadiorite, serpentine, and sheared quartz 
diorite, with a little argillite, the whole cut by several dikes of granodiorite porphyry. The metadiorite, which locally is a metagabbro, much serpentinized, forms the footwall of the vein for some distance southwest of the accessible workings. The hanging wall is largely sheared diorite, with meta-andesite and metadiorite, in some of which tourmaline and metamorphic biotite have been developed, both numerals characteristic of unusually high temperature. Small amounts of argillite occur in both walls, as well as in horses within the vein, commonly near the footwall.

The vein is localized along a fault and consists of quartz, which replaces the gouge and brecciated material between two rather distinct walls. The width between the walls, normal to the fault, is about 60 feet in the accessible workings. The vein strikes N. $30^{\circ}-$ $35^{\circ} \mathrm{E}$. and dips $65^{\circ}-70^{\circ} \mathrm{SE}$. Most of the filling between the walls is country rock, partly replaced by quartz, sericite, and sulphides. Probably less than 10 feet of this filling consists of quartz vein material, however, although most of the filling shows more or less silic-. ification, sericitization, and impregnation with sulphides. The wall rocks bordering the fault zone are similarly altered.

The vein is obviously a replacement vein for the most part, "ghosts" of the country rock being very common throughout it. The sulphides present are pyrite, arsenopyrite, chalcopyrite, pyrrhotite, galena, marcasite, and sphalerite. Microscopic studies show that there are two generations of pyrite. The earlier, euhedral pyrite occurs in a quartz-carbonate gangue, and the later pyrite, with associated marcasite, in fractures and along boundaries of masses of pyrrhotite. According to Mr. Kight there was little or no pyrrhotite in the upper workings. The chief gangue mineral is quartz, but ferriferous dolomite and sericite are very common.

The ore is but slightly oxidized, with the sulphides persisting practically to the surface. Accordingly the ore is rather base, probably less than one-fourth of the gold being susceptible of amalgamation. Cyaniding, however, has never been tried. When the mine was producing, the sulphide concentrate was shipped directly to the smelter.

The tenor of the ore is very irregular. According to Mr. Kight, large quantities will average $\$ 7$ to the ton in gold. There was reported to be a particularly high-grade streak along the footwall, which was worked by a lessee in 1912-1914 with good results, but its tenor is not known.

\section{IAST CHANCE}

The Last Chance group consists of five claims near the head of Ruby Creek, just south of the Dixie Meadows mine. The claims are $164495-33-7$ 
the property of G. H. Kight, of Prairie City. There are about 400 feet of workings.

The country rock consists of sheared gabbro, serpentine, greenstone (meta-andesite), argillite, and sericitized diorite.

The objective of the workings is a mineralized shear zone that strikes N. $60^{\circ}$ E. and dips $60^{\circ}$ SE. There has been considerable sulphidization : and silicification of the footwall of the shear zone, but the hanging wall shows much less. Small veinlets and branching stringers of quartz and sulphides as much as $1 \frac{1}{2}$ feet thick occur.

The diorite just above the hanging wall is much sericitized and carries some sulphides.

The shear zone has been drifted on for about 150 feet. The minerals have been found to occur very irregularly, with some bunches of good ore, but much of the sheared matter is of very low grade. The principal sulphides are pyrite, galena, sphalerite, pyrrhotite, and a little chalcopyrite. The gangue is dominantly quartz with some ferriferous dolomite. Oxidation has been slight, and little of the gold is free. According to Mr. Kight the tenor is not very high, ranging from $\$ 4$ to $\$ 8$ to the ton, even in the highly sulphidic material.

\section{BLACK PRINCE}

The Black Prince property is on the ridge $11 / 2$ miles west of Dixie Butte. It is reached by a mountain road from Prairie City, a distance of about 14 miles. The property is owned by William Walling, of Prairie City, and in 1930 was being developed by Frank B. Prindle.

The prospect consists of one tunnel, slightly more than 750 feet in length, and a small open cut on the surface. (See fig. 10.)

The country rock is largely tourmalinized meta-andesite. Along a fault just inside of the adit portal meta-andesite porphyry occurs. This porphyry may be classified as a greenstone but is less altered than most of the associated rocks. A short distance northeast of the property is a small stock of quartz monzonite.

The country rock has been tourmalinized, silicified, and sulphidized. The metallic minerals are-largely pyrite, with much smaller quantities of magnetite, arsenopyrite, pyrrhotite, chalcopyrite, sphalerite, covellite, and glaucodot (?).

The ore occurs in pockets along fine stringers: No prominent structural features seem to have localized the mineralization. In the tunnel there is one pocket containing considerable glaucodot(?). This pocket is in the lower part of the drift and does not extend into the back. Another similar pocket was found on the sur- 
face, in the present open cut. The adit was driven to connect with a supposed downward extension of this mineralized body exposed at the surface. The best grade of ore carries $\$ 10$ in gold to the ton, according to Mr. Prindle.

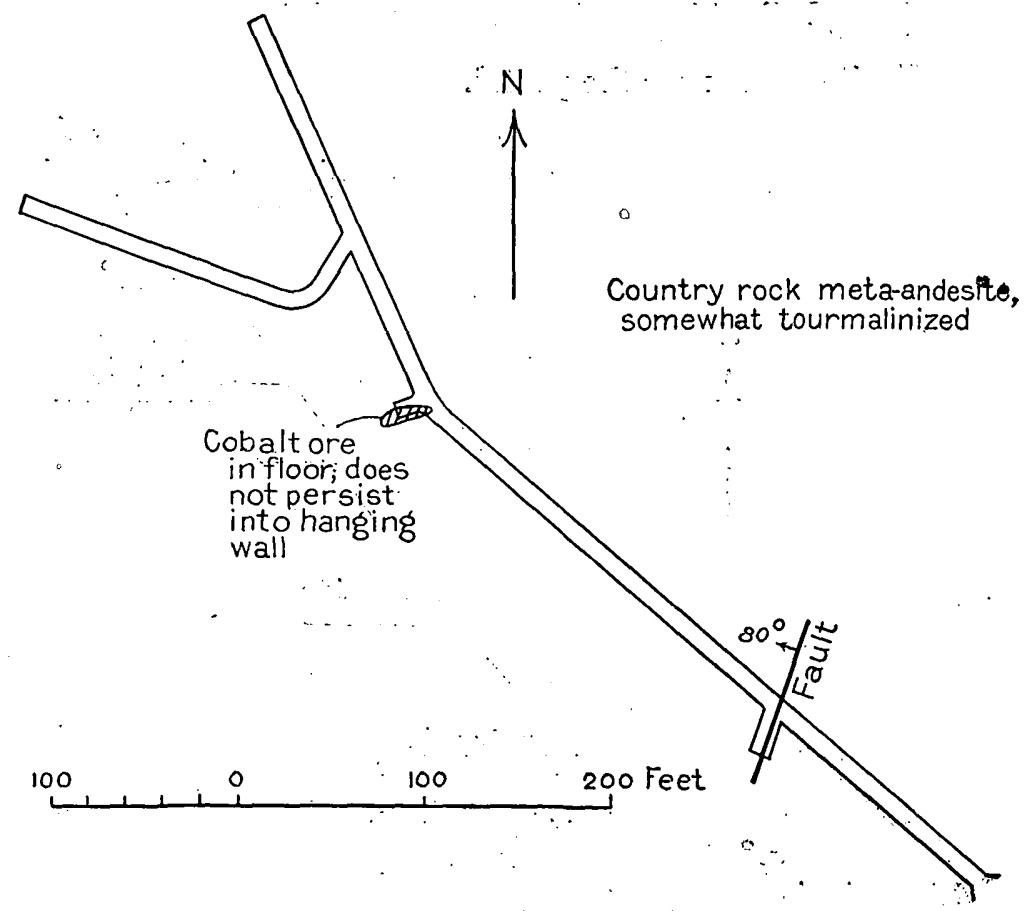

Figure 10.-Map of the workings of the Black Prince prospect, near Dixie Butte, Quartżburg district, Oreg.

EQUITY

- The Equity group of six patented claims is a consolidation of the old Colorado mine and the property known formerly as the Keystone. All the claims are in sec. $2,-$ T. 13 S., R. 33 E., in a small gulch entering the West Fork of Dixie Creek from the south, about 7 miles from Prairie City. A good road gives acess to the property.

The production is not known, but the stoped areas indicate that considerable ore has been removed. Except for the decode 19131922 there has been some activity at the mine every year since 1900 . In 1930 two men were employed in taking out a small quantity of ore below the main level of the Colorado workings.

The Colorado vein has been opened by three levels, the top one 95 feet above the lowest. The vein has been stoped above the lowest level in some places to the surface, and the two upper tunnels are caved and inaccessible. A small amount of work has been done 
below the third level, but these workings are at present filled with water. The work being done in 1930 was 15 feet below the third level. The third level is about 750 feet long and has been stoped upward for 330 feet along the strike of the vein. (See fig. 11.)

The country rock is nearly all sheared gabbro, carrying labradorite phenocrysts in a finer-grained diabasic groundmass. Some dikes of granodiorite occur near the portal.

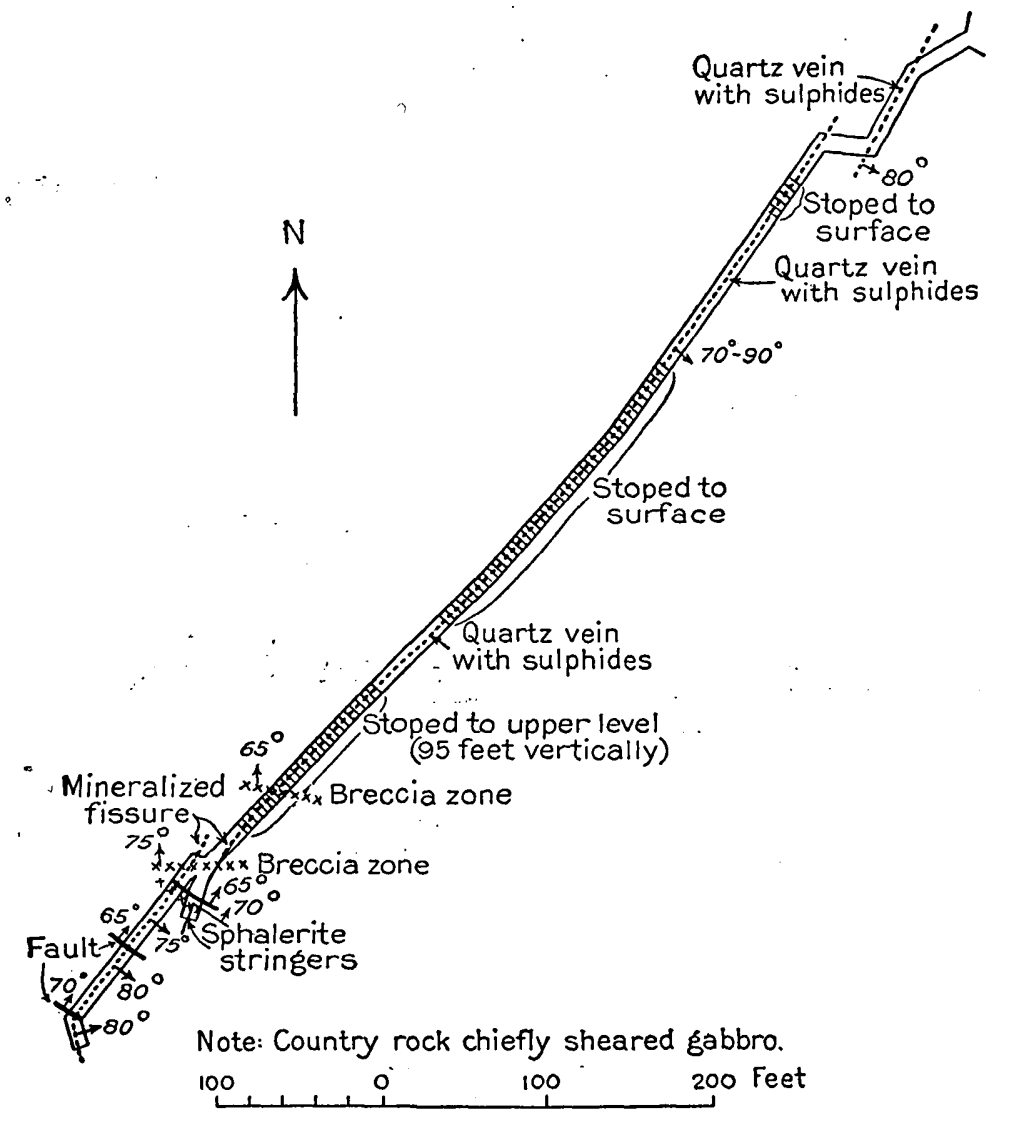

FiguRv 11.-Geologic map of third level, Colorado vein, Equity group, Quartzburg district, Oreg.

The vein strikes about N. $35^{\circ}-45^{\circ}$ E. and dips $75^{\circ}-80^{\circ}$ SE. The vein is composed largely of quartz, dolomite, and massive sulphides-pyrite, chalcopyrite, galena, and sphalerite. The wall rock is slightly sericitic close to the vein. The width of the vein ranges from practically a knife-edge at the face to more than a foot in the stopes.

The rein is crossed by numerous shattered zones of gouge and fault breccia from 3 inches to 3 feet wide. Most of the movement along these breaks appears to have taken place before the mineralization. The quartz vein persists through several of the brecciated areas. 
There has been some postmineral movement, as the vein has been offset 3 feet in one place and possibly 17 feet in another. The faults range in strike from west to $\mathrm{N}$. $65^{\circ} \mathrm{W}$. They all dip. between $65^{\circ}-80^{\circ}$ N. Seven of these fault zones were observed within 200 feet of the face of the third level.

The ore contains considerable massive sulphide and, according to A. W. Ward, of Prairie City, who was familiar with the mine when it was in active operation, carries as much as $\$ 500$ a ton in gold.

The old Keystone workings a few hundred feet to the south were entirely inaccessible in 1930. Apparently this property has not been worked for over 30 years. It was described by Lindgren ${ }^{43}$ as follows :

The old Keystone, now idle, * * * was worked in 1882, during which year the small veins of Quartzburg produced "about $\$ 12,000 ; * * *$ about seren levels were run. In 1883 it is reported that 500 tons of ore at $\$ 40$ per ton were worked at a cost of $\$ 8.50$ per ton. In 1889 the mine is credited with a production of $\$ 5,800$. The vein strikes northeasterly and dips southeasterly. It is 4 feet wide between walls, the pay forming a narrow streak on the hanging, on the foot, or on both. The gangue contains much calcite, but otherwise the ore is similar to that of the Present Need:

PRESENT NEED

The Present Need mine is on the West Fork of Dixie Creek about a mile above the forks and a few hundred feet below the Keystone workings. No activity has been reported at this mine since 1912, and none of the workings were accessible in 1930. It was under lease to Ed Gifford, who planned to open and unwater the drifts. The property has been described as follows by Lindgren $:^{44}$

The Present Need was located about 10 years ago [1890] and has since been worked on a small scale, the ore being calcined in a kiln and then reduced in an arrastre. The developments consist of a crosscut tunnel 100 feet above the creek level and 200 to 300 feet of drifts. The country rock is diabase, but the crosscut has exposed a narrow, greatly contact-metamorphosed series of diabase tuff with a general east-west direction. The vein strikes N. $20^{\circ}$ E. and dips $70^{\circ} \mathrm{ESE}$. Like the other veins in the district, it is not traceable for a long distance. The width is 2 to 3 feet, indicated by fissures in the hard diabasic rocks. The ore occupies from 4 inches to 2 feet of this width and consists of solid quartz with heavy sulphurets in irregular intergrowth. There are pyrite, hard and yellow, softer yellowish-gray marcasite, and a little chalcopyrite, zinc blende, and galena. This ore is very rich, and the pyrite often contains free gold. It assays from 6 to 25 ounces silver and 4 to 5 ounces in gold per ton, a total value of about $\$ 100$. With the imperfect extraction used, only about two-thirds of this amount was saved.

The ore occurs in two shoots on the vein, both dipping $65^{\circ} \mathrm{S}$. on the vein; the shoots are 70 feet long and are separated by a barren zone of 70 feet.

Since the time of Lindgren's examination the vein has been exploited to a point just above the level of the creek. 
: The Paul Tote property, owned by A. W. Ward, of Prairie City, is on the northeast side of the West Fork of Dixie Creek, a short distance above the forks. No production has been made.

About 700 feet of tunnel has been driven, including about 300 feet of crosscut, and nearly 400 feet of drifts on two intersecting veins. (See fig. 12.) A winze 22 feet deep has also been sunk.

The country rock is all greenstone. The intersecting veins strike N. $10^{\circ}$ W. and N. $10^{\circ}-25^{\circ}$ E., and both dip about $75^{\circ}$ E. The two veins contain the same types of minerals, and there is no offset at the intersection. The vein that strikes east of north is 3 inches to 2 feet wide, the other has a maximum exposed width of 8 feet and pinches down to 6 inches. The vein material consists of sheared and altered



Figurp 12.-Workings of Paul Tote prospect, Quartzburg district; Oreg. greenstone, stringers of $N$ calcite, small amounts of $\uparrow$ quartz and pyrite, and chalcopyrite: Some fine sericite flakes coat fractures through the calcite.

According to $\mathrm{Mr}$. Ward, the average tenor of the ore in the northwesterly vein is $\$ 7$ to the ton in free-milling gold, with additional values in the sulphides.

\section{KLONDIKE}

The Klondike, owned by A. W. Ward, of Prairie City, is on the northwest side of the East Fork of Dixie Creek, just above the forks. It is about 6 miles from Prairie City.

The property has been opened by several hundred feet of workings, partly in greenstone and partly in a diorite porphyry dike. This dike, which strikes N. $25^{\circ}$ E. and is 75 to 90 feet thick, cuts through the greenstone. The vein, consisting of about 2 feet of gouge and breccia, apparently follows the east wall of the dike. It strikes N. $25^{\circ} \mathrm{E}$. and is either vertical or dips steeply east. About 33 tons of high-grade ore has been extracted from a small pocket. Very little quartz is present in the vein. The greenstone along the vein is locally impregnated with considerable pyrite.

\section{COUGAR}

The Cougar prospect, owned by A. W. Ward, of Prairie City, is in.sec..2, T. 12.S., R. 33 E., on Cougar Ridge, between the two main forks of Dixie Creek. Four claims are included in the property. 
There "were several small tunnels accessible in 1930, and the whole hill is dotted with small open cuts and other tunnels, no longer open.. A small production has been reported in 1918, 1919, and 1923. In 1930 the principal work was being done on the. Blue Mountain Chief claim.

The country rock is greenstone, cut by a diorite porphyry dike continuous with that in the Klondike prospect.

The vein exposed in a drift on the Blue Mountain Chief claim strikes N. $10^{\circ} \mathrm{W}$. and dips $60^{\circ} \mathrm{E}$. at one point but elsewhere swings to due north and dips $65^{\circ} \mathrm{W}$. Like that in the Klondike prospect, it follows the east wall of the dike. It has been followed in the drift for 270 feet and ranges in this distance from 3 inches to 1 foot in thickness. The vein is composed of quartz, gouge, and calcite, containing pyrite, chalcopyrite, and a little galena. Assays as high as $\$ 450$ to the ton in gold and silver have been reported from these sulphides. ${ }^{45}$

Other veins are exposed in near-by excavations. Most of them strike between north and N. $20^{\circ} \mathrm{E}$. and dip steeply east. These veins are all small stringers of quartz and gouge in which the valuable metals are : very sporadically distributed. No production has been reported.

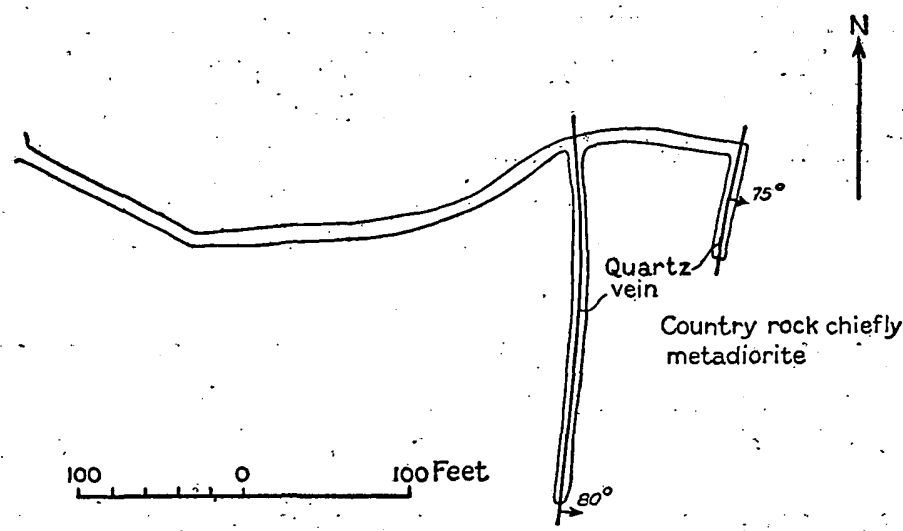

Frgure 13.-Workings on lower tunnel level, Yankee Boy vein, Quartzburg, Oreg.

\section{YANKEE BOY}

The Yankee Boy group, owned by $\ddot{A}$. W. Dunn, of Prairie City, includes three claims on the hillside northeast of the West Fork of Dixie Creek about a mile above the forks.

The workings include three tunnels at different altitudes on the same vein, called the Yankee.Boy. The upper tunnel is caved and inaccessible. The middle tunnel includes about 135 feet of workings; the lower tunnel about 550 feet. (See fig. 13.) No production has been reported.

4 Parks, H. M., and Swartley, A. M., Handbook of the mining industry of Oregon: Mineral Resources of Oregon, vol. 2, No. 4, p. 82, Oregon Bur. Mines and Geology, 1916. 
The country rocks are chiefly altered diorite and andesite. The vein followed by the middle tunnel is about a foot wide and consists of a shear zone in the diorite, with stringers of quartz. It strikes N. $20^{\circ}$ E. and dips $85^{\circ}$ E. Two fissures are exposed on the lower level. The one nearest the face, which has been followed for about 50 feet, strikes $\mathrm{N} .10^{\circ} \mathrm{E}$. and dips $75^{\circ} \mathrm{E}$. It consists of about 3 inches of gouge, quartz, and calcite, with pyrite, chalcopyrite, sphalerite, and galena. The diorite country rock is highly chloritic along the vein. The other fissure strikes about N. $5^{\circ}$ E. and dips $80^{\circ} \mathrm{E}$. It is about 6 inches wide and contains the same minerals as the first but is much more brecciated.

\section{DIXIE QUEEN}

The Dixie Queen property is on the nose of Cougar Ridge between the East and West Forks of Dixie Creek. There are five claims in the group, held by Charles Bartlett.

The country rock is greenstone cut by diorite dikes. In several places the veins follow the contacts of these dikes.

The Dixie Queen adit has been driven 200 feet and it is planned to continue this adit until a vein that crops out on the surface has been intersected. There are three small seams cut by the tunnel. These fissures contain a little quartz, gouge, and breccia, with sulphides. The veins strike N. $15^{\circ}$ W. to N. $15^{\circ}$ E. and dip about $80^{\circ} \mathrm{E}$.

On the surface and in the numerous other small tunnels and open cuts small veins are exposed. These veins have a remarkably persistent strike of $\mathrm{N} .10^{\circ} \mathrm{E}$. and a dip of about $75^{\circ}-80^{\circ} \mathrm{E}$.

\section{FITZSIMMONS}

The Fitzsimmons group of five patented claims is on the hillside northwest of the East Fork of Dixie Creek, just above the old smelter. The claims are owned by Mrs. Durkhammer, of Salem, Oreg.

Considerable work has been done here in the past, but the tunnels are all caved and inaccessible. The material on the dumps is very similar to that of the Cougar and Dixie Queen groups. It is chiefly greenstone with some diorite. The greenstone contains considerable pyrite.

\section{FORRESTER}

The Forrester group of 11 claims is on a small creek flowing eastward into Dixie Creek, just below the forks in Dixie Creek. The group is owned by the Utah-Oregon Gold Mining Co., incorporated under the laws of Utah. The property is in charge of A. W. Ward, of Prairie City, Oreg. 
The main tunnel has about 500 feet of accessible workings. (See fig. 14.) There are two more small tunnels open and numerous surface cuts.

The vein follows the contact of a dike of sericitic diorite porphyry in granodiorite and greenstone. This dike ranges in width from 20 to 60 feet and, according to Mr. Ward, has been traced for 2 miles on the surface. The vein follows the hanging-wall contact, striking N. $5^{\circ}$ E. and dipping $80^{\circ}$ E. The dike has been crosscut, and the face of the workings is in greenstone. The walls of the dike are very irregular.

Most of the country rock is medium-grained granodiorite that contains considerable quartz. Masses of greenstone, probably inclusions in it, are common.

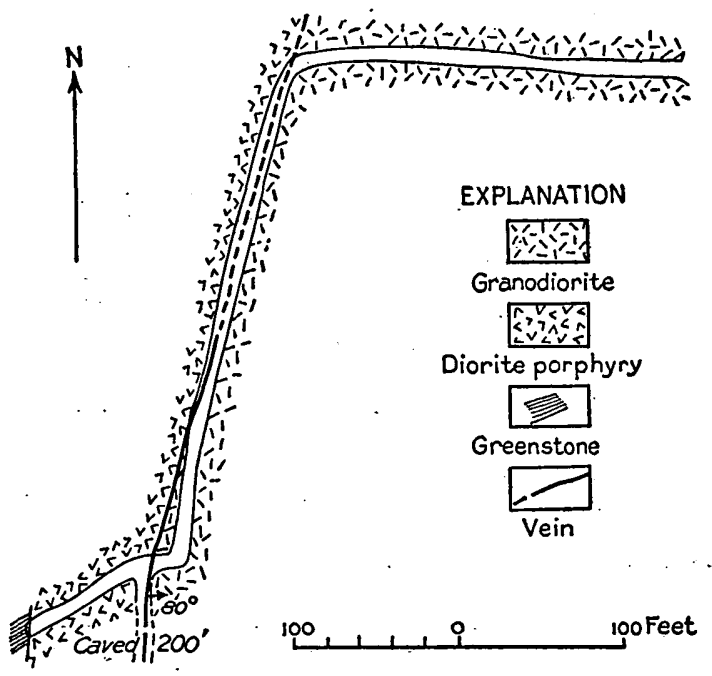

FigURb 14.-Geology of New Forrester tunnel, Forrester group, Quartzburg district, Oreg.

The vein consists of about $11 / 2$ feet of gouge and breccia with small amounts of quartz. The gold is both free-milling and base. Pyrite is the main sulphide, but others are reported to be present, though no others were seen.

The so-called Old Forrester workings consist of a drift 185 feet long, a quarter of a mile southeast of the work described above. The drift crosscuts a dike 45 feet wide and then follows northward along the contact, which strikes $\mathrm{N} .15^{\circ} \mathrm{W}$. and dips $85^{\circ} \mathrm{E}$. This contact is followed by about 2 feet of gouge and clay. The country rock is granodiorite; and the dike material is very similar to the diorite porphyry described above. 
The vein in the old workings carries only about $\$ 2$ to the ton in gold. The main workings average better than this amount, according to Mr. Ward, but no figures were obtained.

\section{ANDREW JACKSON}

The Andrew Jackson property consists of one claim on the West Fork of Dixie Creek just above the Sherbandy group of the Copper Mountain Mining Co. The claim is owned by Mark Carmichael and Helbert Schoenthal. There are an open cut and two small tunnels, aggregating 145 feet of drifts, on the claim. The country rock is greenstone and diorite. At least two small seams of quartz are exposed. These seams average about 3 inches in thickness and contain a little gouge. One strikes N. $20^{\circ}$ E. and dips $80^{\circ}$ E.; the other strikes N. $65^{\circ}$ E. and dips $65^{\circ} \mathrm{W}$ :

\section{BOULDER}

The Boulder group of seven claims, the property of David R. Roberts, of Prairie City, is near the head of a west branch of Dads Creek. The property is reached from Prairie City by about 8 miles of road and a 3-mile trail.

The work done aggregates about 1,000 feet, chiefly drifts and crosscuts on two levels about 100 feet apart. . No production has been made.

The country rock-consists chiefly of porphyritic meta-andesite, silicified and altered to a very dense, hard rock. Possibly some old pyroclastic rocks are included. It is cut by a few dioritic dikes and by faults and fissures that trend generally N. $70^{\circ}$ E. to S. $70^{\circ} \mathrm{E}$. and dip steeply southward.

The mineralization consisted of silicification and impregnation of the walls of a fault with sulphides and arsenides. Veins that range from a knife-edge to 4 inches in thickness follow the fault walls. Pyrite, arsenopyrite, chalcopyrite, sphalerite, pyrrhotite and glaucodot were noted, together with quartz and a little calcite. The oxidation minerals limonite, malachite, erythrite, and azurite were seen, but only very near the surface. Fresh sulphides occur in the lower tunnel less than 150 feet beneath the surface.

Mr. Roberts reports that picked ore in the mine assays as high as 8 per cent of cobalt, 2 per cent of copper, and $\$ 2$ in gold to the ton. It seems unlikely that large tonnages of this tenor are present:

\section{HOWELL \& HAIGHT}

The property owned by Howell \& Haight, of Prairie City, is on top of the ridge to the east of Dixie Creek and at the head of a tributary to Corral Creek. In 1930 there was a 30-foot shaft on the 
property, and at the time of visit this was being unwatered, preparatory to deepening.

The country rock is diorite cut by a porphyritic diorite dike.

The vein consists of a high-grade streak, which forms the hanging wall of the porphyry dike and strikes N. $20^{\circ}$ E. and dips $45^{\circ} \mathrm{SE}$. According to Mr. Howell there is also, in the dike just below, about 20 feet of ore carrying $\$ 4$ to $\$ 5$ to the ton in gold. The gold is free within the depth so far explored. Pyrite, quartz, and free gold occur along the contact and impregnating the dike. No production. had yet been made in 1930 .

\section{COPPER MOUNTAIN MINING CO.}

The property of the Copper Mountain Mining Co. embraces 11 claims on Cougar Ridge, west of the East Fork of Dixie Creek, in sec. 1, T. 12 S., R. 33 E. Four of the claims, called the Sherbandy group, were patented. The property is about 8 miles from Prairie City. In 1930 it was under the management of V. E. Ryan.

The claims constituting the Sherbandy group were located in 1896 by Capt. Homes Sherbandy and his son Byron. Development work was confined to a few shallow cuts and two short tunnels until the spring of 1930, when the present owners, who had taken over the property in 1929, began driving a crossicut about 300 feet below the apex. At the time of visit this crosscut was about 80 feet long. The total underground workings amounted to less than 400 feet. No production has been made.

The country rock consists of altered andesite and diorite, cut by some dikes of granodiorite porphyry. Several narrow veins are exposed in the tunnel. Most of them strike N. $45^{\circ}$ E. and dip steeply southeast. Some are fault veins and show brecciation, sericitization, silicification, and sulphide impregnation of their wall rocks in zones that extend 2 to 6 feet from the veins. One of these fractures follows a much decomposed dioritic dike that trends N. $35^{\circ}$ E. The more intense mineralization, however, seems to have been but slightly controlled by these fractures. The most prominent mineralized bodies are tourmaline-quartz-chalcopyrite replacement masses in the greenstone. These bodies trend in general east to northeast. Some show elongation along steeply northward-dipping fractures with trends $\mathrm{N}$. $60^{\circ}-85^{\circ} \mathrm{E}$; ; others seem independent of such control: The tunnel being driven in 1930 had as its objective the discovery of the intersection of a vein that runs N. $30^{\circ} \mathrm{E}$. and dips steeply west with a generally eastward-trending tourmalinequartz mass.

The minerals present are pyrite, chalcopyrite, and bornite in a gangue of tourmaline and quartz, with a little sericite and a clay 
mineral that resembles beidellite. Malachite, azurite, and limonite occur in the gossans.

\section{COPPEROPOLIS}

The Copperopolis property is in sec. 6, T. 12 S., R. 34 E., just west of the East Fork of Dixie Creek. It is reached by an 8-mile wagon road from Prairie City.

The developments include several short tunnels and one about 1,500 feet long that cuts the deposit at a depth of about 300 feet. About 250 tons of ore was milled in a small concentrator, which was closed in $1906 .^{46}$

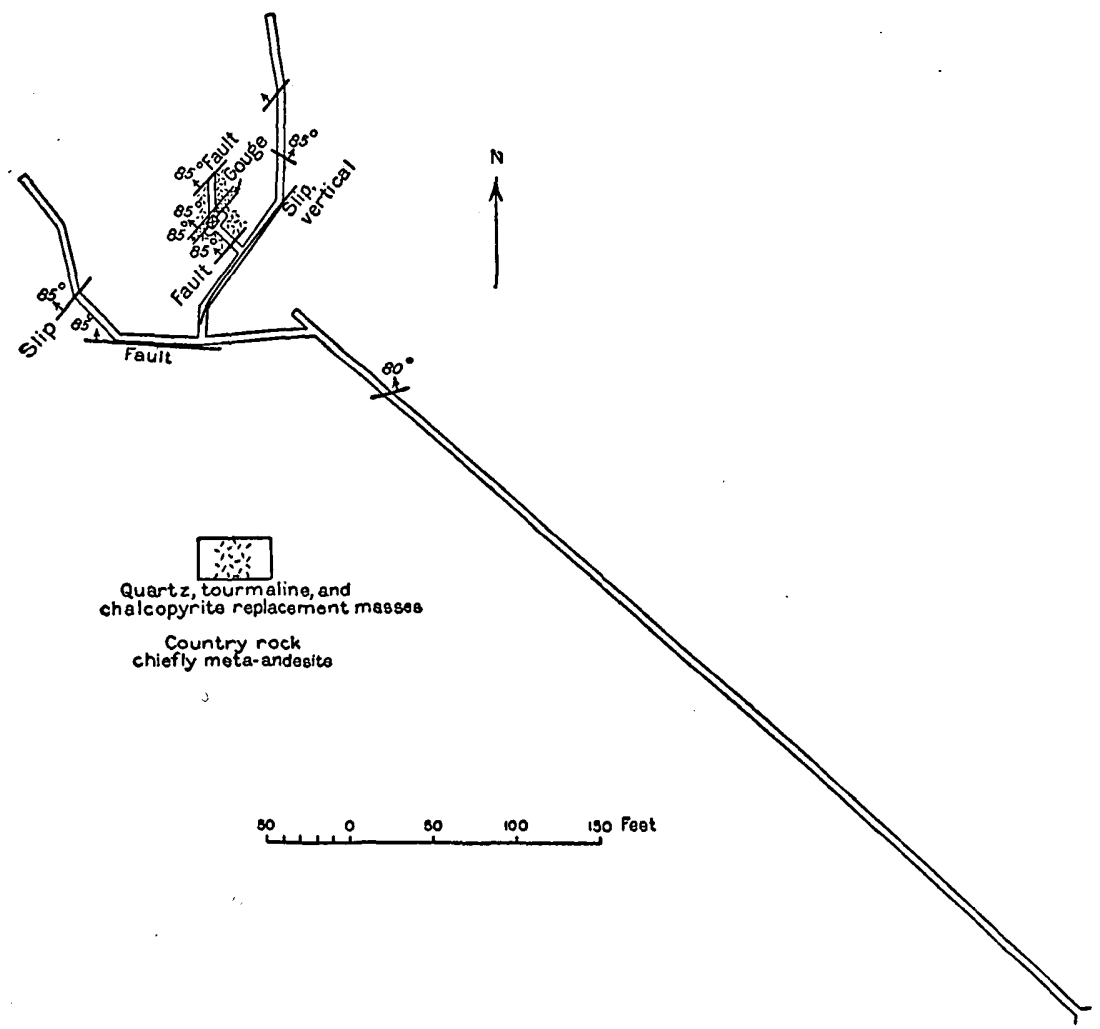

FigdRE 15.-Map of Copperopolis mine, Quartzburg district, Oreg.

The country rock is blocky meta-andesite, metadiorite, and diabase in which is developed a steeply dipping replacement body of quartz, tourmaline, and chalcopyrite. (See fig. 15.) This replacement body is apparently localized along a fissure that strikes about N. $60^{\circ} \mathrm{E}$. on the surface. Mineralization followed this fissure from the Sherbandy group of claims to the Copperopolis ground. The surface outcrops in the Copperopolis claims show a replacement mass about 1,000 feet long and 75 feet wide at the widest place,

${ }^{\iota 6}$ Parks, H. M., and Swartley, A. M., op. cit., p. 73. 
where an unreplaced horse of country rock 35 feet wide is included. On the tunnel level, however, the mass is much reduced to a body about 40 feet wide split by a 5 -foot gouge mass. It is apparently controlled by fractures that strike N. $45^{\circ}$ E. and dip steeply and is itself sheeted by steep fractures that strike N. $20^{\circ} \mathrm{W}$. It is almost wholly composed of milky quartz, with scattered nests of pyrite, chalcopyrite, and tourmaline. Small amounts of magnetite, hematite, cobaltite, tetrahedrite, bornite, galena, and sphalerite occur. Crosscuts have been driven across both ends of this replacement body. In all directions the mass has remarkably sharp boundaries; although seams of flamboyant quartz, dolomite, and chalcopyrite extend out in several directions, they are all of negligible width.

Assays representative of the mass as a whole are not available. Considered as a copper ore it must be of rather low grade, but this may be in part compensated by the gold content, which according to some picked samples, may run close to $\$ 1$ to the ton.

The mineral sequence is apparently tourmaline, quartz, and sulphides.

\section{STANDARD}

The Standard group of 21 patented claims is controlled by the Mercantile Commerce Niational Bank, of St. Louis, Mo. H. W. Riley is in charge of the property, which is about 7 miles from Prairie City, on the East Fork of Dixie Creek.

Development on the property began about 1880, but at the time of Lindgren's examination in $1900^{47}$ only the upper tunnel and the inclined shaft, a total of probably 600 feet of workings, had been driven. The mine was most actively exploited between 1900 and 1907, when about 4,000 feet of development and considerable stoping were done. Except for a few feet of drifting in 1915 and the shipment of a few tons of ore to the Sumpter Smelter in 1923, the mine has since been idle.

Data on production are very incomplete. Prior to 1900 the mine had shipped a few tons of chalcopyrite-gold ore from the shaft:

In 1900 Lindgren reports a shipment of 10 tons of $\$ 34$ ore from the upper tunnel. D. F. Hewett, of the United States Geological Survey, who visited and mapped the mine in 1915 and whose notes have been freely utilized in the present description, obtained production data which show that the mine shipped about 104 tons of concentrate in 1906, yielding a net return of about $\$ 50$ a ton, and that the shipments in 1907 were about 311 tons, which yielded a net return of just over $\$ 45$ a ton. The concentrates averaged 60 cents in gold and a little less than an ounce of silver to the ton and 10

47 Lindgren, Waldemar, op. cit., pp. 711-712. 
to 12 percent copper. According to Mr. Riley, some cobalt ore was shipped to the Edison Laboratory, but he was unable to state the amount or value of this shipment.

There are several veins that have been partly developed-the Standard, Grover Cleveland, Juniper, and Smuggler. The bulk of the production has come from the Standard, but some ore was obtained from the Grover Cleveland.

The Standard vein has been opened by an inclined shaft about 70 feet deep and by three adits at vertical intervals of about 80 feet. The upper tunnel was caved and inaccessible in 1930, but Mr. Hewett's map (pl. 7) shows it to be about 400 feet long. The middle level contains 600 feet of drifts. The lower level includes about 1,700 feet of drifts and about 1,000 feet of crosscuts. Part of the workings in the lower level are caved and inaccessible. There are numerous raises and stopes connecting the levels. No work has ever been done below the third level. (See pl. 7.)

The country rock of the Standard vein is chiefly porphyritic andesite, with some vesicular andesite, cut by dikes of granodiorite porphyry and a few of diabase. The vein itself is localized along a fault, and there are at least four distinct fault-breccia zones crossing the vein. The vein strikes persistently N. $70^{\circ}-75^{\circ}$ E. and dips steeply south. Much of the movement along the faults has been premineral, but in one place there is a slight jog in the vein, and in the face the vein appears to be faulted off. No work has been done beyond the immediate fault contact.

There is one crosscut to the south from the Standard vein for about 400 feet. This cuts five small veins or mineralized stringers that strike N. $45^{\circ}-80^{\circ} \mathrm{E}$. and $\operatorname{dip} 60^{\circ}-80^{\circ} \mathrm{S}$.

The Standard vein ranges in width from a few inches to 4 feet. It is not a strong persistent vein but rather a group of mineralized stringers with considerable replaced wall rock. The main gangue mineral is quartz, but some ferriferous dolomite and calcite are also present. The ore minerals are pyrite, chalcopyrite, arsenopyrite, cobaltite, glaucodot, bismuthinite, native bismuth, galena, and sphalerite. The glaucodot, which has been called smaltite and safflorite in other reports, is present in the deeper workings. Considerable cobalt bloom, erythrite, is present in the lowest drift, and some nickel bloom(-?), jarosite, and malachite also occur. The average tenor of the ore is not known.

The fault zone nearest to the adit is called the Grover Cleveland vein and has been drifted on for about 600 feet. It strikes N. $20^{\circ}$.$40^{\circ} \mathrm{E}$. and dips about $80^{\circ}$. S. Most of this work is now caved. To the northwest of the Standard vein another tunnel has been driven for 700 feet. This tunnel also cuts the Grover Cleveland vein, and 
some work was done here. The Grover Cleveland vein follows in part a dike of granodiorite porphyry. and consists of a shattered and brecciated zone about 8 feet wide containing breccia, gouge, and small quantities of quartz, ferriferous dolomite, and sulphides. The ore is free-milling and carries about $\$ 2$ in gold to the ton according to Mr. Pinson, former manager of the company.

The other fault zones that cross the Standard vein have not been followed at all. These fault zones consist of breccia and gouge and range in width from 6 inches to 3 feet. The exposures are very poor at the face, and nothing can be said regarding the fault that cuts off the vein.

The Smuggler vein is exposed in an open cut on Dixie Creek a few hundred yards above the main Standard mine. It is a diorite dike, silicified and mineralized. Numerous spots of brownishblack tourmaline are present. The sulphides are pyrite, chalcopyrite, and bornite. The dike strikes N. $60^{\circ}$ E. and dips steeply north. The dike has been followed by the miners for over 1,500 feet on the surface. The wall rock of the diorite dike is greenstone. The walls are very indefinite and irregulàr.

The Juniper vein is southeast of the Standard vein; in Ella Gulch, a small branch of Dixie Creek. The vein is opened along the strike by a tunnel 900 feet long. The vein strikes N. $75^{\circ}-80^{\circ}$ E. and dips about $80^{\circ} \mathrm{S}$. It ranges in width from 3 inches to about 3 feet: Sulphides, chalcedony, and quartz are the common constituents. The sulphides are pyrite, chalcopyrite, and arsenopyrite. Two spots of cobalt bloom were noticed. At the face the strike of this vein is N. $80^{\circ}$ E. and its $\operatorname{dip} 70^{\circ}$ S. The vein swings and in one place strikes due east.

In the Juniper vein, as in the Standard vein, several breccia zones cross or are crossed by the vein, with very little or no offset along either one. In the Juniper drift these zones strike N. $5^{\circ} \mathrm{E}$. to due north and dip about $75^{\circ}-80^{\circ} \mathrm{E}$. They contain from a few inches to several feet of gouge and breccia. The wall rock is all meta-andesite, some so much altered as to resemble hornfels. Much tourmaline is.present in it.

The sequence of mineralization has been tentatively worked out by combining the observations of Mr. Hewett and the writers as follows:

First the andesite was altered to "hornfelslike" masses, the joints of which were locally coated with tourmaline. Calcite, the metallic minerals (beginning. with pyrite and arsenopyrite), ferriferous dolomite, quartz, a second generation of calcite and pyrite, chalcedony, and marcasite, followed in order. Of these, the chalcedony and marcasite are probably supergene. 
DIXIE CREER PLACERS

The Dixie Creek placers have been described by Lindgren ${ }^{48}$ as follows:

The Dixie Creek placer mines were discovered about 1862, and were reported rich, though no data as to production are at hand. Raymond's report for 1870 contains the statement that at that time there were 100 white men and 200 Chinamen employed, and that the fine scaly gold was 0.860 fine. In 1873 the creek is reported as turned over to Chinese labor. In 1882 two small hydraulic plants were in operation, producing $\$ 30,000$ (mint report). At the present time [1900] very little placer mining is done.

The placers consist of the gravels accumulated in the present creek to a depth of 10 or 15 feet. The workings extend upstream from Prairie for 5 miles, or to the entrance of the diorite canyon, where the grade becomes very steep. The width of the gravel-covered river bottom is from 300 to 800 feet, the whole of which has been worked.

Six miles east of Prairie are the old Spanish Diggings, which have yielded a moderate amount of gold. The upper end of John Day Valley contains no placers. On the east side of Dixie Butte are the old placers of Happy Camp, still worked on a small scale by Chinese. Northwest of the same mountains are the Ruby Creek placers, still worked by whites and Chinese. Small placers are also reported from the head of Camp Creek.

Swartley ${ }^{40}$. states that local estimates of production from the Dixie placers range from $\$ 600,000$ to $\$ 6,000,000$, with the smaller figure probably being nearer the true one.

In 1930 a dredge owned by the Empire Gold Dredging Co. and managed by $R$. C. Reese was operating in the gravel just below the town of Prairie City. This dredge had been installed on Canyon Creek just above John Day in 1916 and operated there for 12 years, digging between 300 and 400 acres of 12 -foot ground. In 1929 it was moved to the Prairie City ground. It was digging 22 feet to bedrock in a pay streak about 700 feet wide. Mr. Reese estimated that a 4 to 5 year run remained ahead of the dredge at this site. The dredge has 6 -foot buckets and a capacity of about 3,000 cubic yards a day, but owing to irregular power supply it operates only intermittently during the irrigating season.

\section{COMINI QUARRIES}

L. Comini \& Sons have opened three small quarries in diorite about 4 miles up Dixie Creek from Prairie City.

The stone differs in color in the three quarries, that in the quarry nearest to the town being darkest and that in the quarry farthest away being lightest. In 1930 practically all the work was being done in the middle opening. The rock is a moderately fine-grained gray diorite but contains a large number of dark inclusions; which are of course very undesirable in monumental stone, leading to a

${ }^{\$ 8}$ Lindgren, Waldemar, op. cit., p. 712. ${ }^{\star 0}$ Swartley, A. M., op. cit., p. 198. 

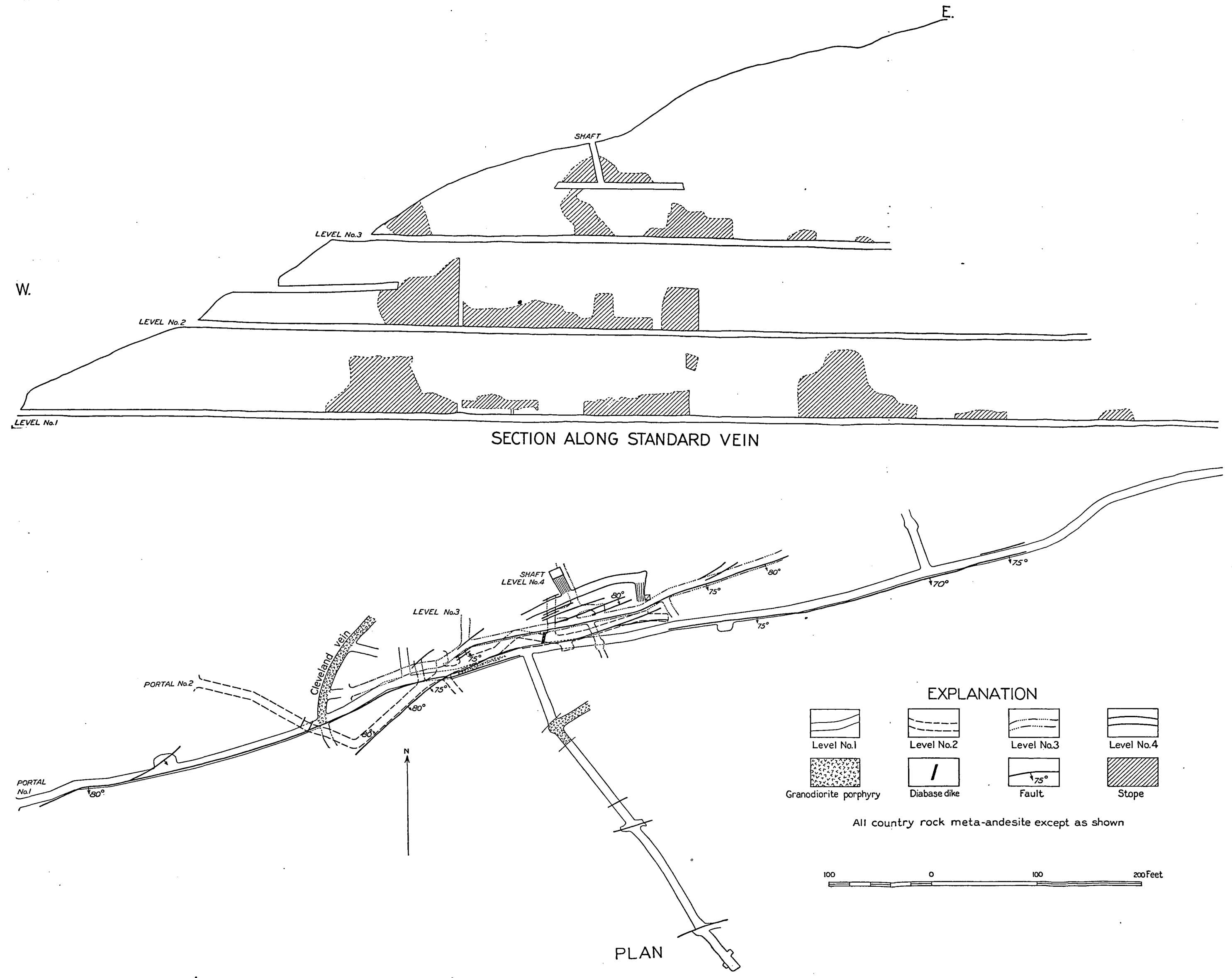

MAP AND SECTION OF STANDARD MINE, QUARTZBURG DISTRICT, OREG.

From notes by D. F. Hewett, 1915. 
considerable waste in partly worked stone. Efforts were being made to find an area free from these inclusions, which, however, had not been done at the time of visit.

\section{OUTLOOK FOR THE DISTRICT}

The Quartzburg district is under the disadvantage of being far from reduction works, so that ore must be of very high grade to warrant transportation charges. Mineralization is widespread, and several of the properties might prove profitable if worked on a moderate scale, but the deposits so far discovered, with the possible exception of the Dixie Meadows and Copperopolis, are hardly. of a size sufficient to warrant large development campaigns. The Dixie Meadows and Copperopolis deposits are of considerable size, and it is possible that if the grade of the material warrants they may justify work on a larger scale. In absence of systematic assaying, however, it is not justifiable to assume that they warrant development, at least until mining and transportation costs become lower.

In a district in which the rocks have been so widely mineralized and in which prospecting is so difficult there is a considerable probability that other deposits may be present, perhaps more attractive than any so far known. On the evidence available in 1930, however, the Quartzburg district seems destined to remain a potential rather than an actual producer, until the transportation handicaps are overcome.

\section{SUSANVILLE DISTRICT}

\section{GEOGRAPHY}

The Susanville mining district is in Grant County about 18 miles down the Middle Fork of the John Day River from Austin. Most of the district is in the northwestern part of T. 10 S., R. 33 E. but it extends slightly into the adjoining townships on the north, northwest, and west. The mines are all on the north side of the river and are concentrated principally along Elk Creek, a small tributary that enters the river in sec. 13, T. 10 S., R. 32 E. Deep Creek, the next tributary entering the river from the north below Elk Creek, may be considered the northwestern boundary of the area. The relief in the immediate district is probably less than 1,000 feet, but the slopes in general are steep. The country is heavily wooded. The rainfall is moderate, but heavy snows are common in winter.

Susanville post office is on Elk Creek about $1 \frac{1}{2}$ miles above its mouth. The nearest railroad is the narrow-gage Sumpter Valley Railway at Austin. In summer the road from Austin to Susanville $164495-33-8$ 
is in fair condition. It is 3 miles by graded road from Austin to Batesville on the John Day Highway. Susanville may also be reached from the John Day Highway at Kimberley at the confluence of the North Fork and the main river by following up the North Fork.

\section{FIELD WORK}

No base map was available, and because of the timber the district is not favorable to plane-table maṕping, so no geologic map was made. The work was confined to an examination of the accessible mines and prospects and to a geologic reconnaissance of the district. About a week was spent in the area.

\section{GEOLOGY}

\section{GENERAL FEATURES}

The country rock of most of the Susanville district is schist. Lindgren ${ }^{50}$ believed the schist to be Paleozoic, probably Carboniferous, but as no fossils have been found its age is uncertain. In the schist series quartzite, greenstone, and slate occur in subordinate amounts. This series is the oldest formation in the district.

The schists were intruded by bodies of basic and ultrabasic rocks, which originally were gabbros and peridotites. These bodies have been sheared and altered and are now for the most part serpentinous rocks, although some unaltered gabbro and peridotite occur.

The district is bounded on the north and northeast by the edge of a large quartz diorite mass, which according to Lindgren's map ${ }^{50}$ extends eastward for at least 15 miles and forms the country rock of the Greenhorn mining district. The quartz diorite is a younger intrusion than the basic ones just mentioned. Aplite dikes cut the schists and the basic rocks. Presumably the dikes are related to the quartz diorite intrusion. The age assigned to the intrusion by Lindgren ${ }^{51}$ is post-Jurassic and pre-Chico, and no reason was found to question this assignment.

Here and there over the higher land in the district occur areas of the Columbia River lava, remnants of more or less continuous flows, which at one time blanketed the whole district. Near the borders of the district the lava areas become larger-in fact, the district is almost encircled by lava flows. The older rocks are exposed as a result of the removal of the lava cover by the streams.

The valley of the Middle Fork of the John Day River is floored with gravel of Quaternary age. The gravel extends continuously up Elk Creek as far as Susanville, and considerable areas are found even farther up the creek. 


\section{SCHIST SERIES}

The dominant rock of the schist series is a gray actinolite-talc schist. A conspicuous feature of the rock, in addition to its soapy feel, is that it has developed a linear schistosity as well as a plane schistosity. Hand specimens show this feature by being striated parallel to the strike of the rocks. The schist is probably of sedimentary origin and contains carbonaceous material, and at some localities much graphite is developed along the shear surfaces. Black carbonaceous slate is included in the series in a few places.

Near the Princess mine a fine-grained biotite schist occurs close to the quartz diorite contact. Cleavage surfaces of this rock are black with small bright flakes of biotite.

No limestones were found in the schist series in the Susanville district, but a few thin beds of quartzite were observed. On the hill above the Skyscraper claim a conglomerate occurs in which are subangular chert pebbles as much as $1 \frac{1}{2}$ inches across. Some greenstone, probably of pyroclastic origin, is also represented.

Altered andesitic flows are locally interbedded in the schist series. They are especially conspicuous in the area around and between the Bull of the Woods and the Poorman properties.

\section{BASIC INTRUSIVE ROCKS}

Gabbro and associated peridotite and serpentine are not common in the district. Basic rocks are conspicuous, however, around and north of the Gem mine and between the Bull of the Woods and Side Issue mines. These rocks are in general highly sheared and altered, but in a few places original textures are preserved. Dark-green sheared serpentine is the chief representative and is well exposed along the road above the portal of the Bull of the Woods mine. In the immediate vicinity of the Gem mine the basic rock is altered peridotite. It contains tremolite, serpentine, pyroxene, magnetite, pyrrhotite, and a little relict olivine.

\section{QUARTZ DIORITE AND RELATED DIKES}

The quartz diorite that bounds the Susanville district on the north and east is but the border of a large mass that extends for a long distance toward the east. This rock is in places gneissic near the borders but is almost massive away from the contacts.

The rock is light colored, coarse or medium grained, and granitic, with biotite, hornblende, quartz, and feldspar visible in hand specimens. Locally it is sheared, but nowhere to a degree comparable to that of the basic intrusive rocks.

Microscopically the essential minerals are seen to be basic oligoclase, quartz, hornblende; biotite, and in some specimens a little augite. Apatite, zircon, titanite, and magnetite occur as accessories. 
The numerous porphyry dikes that cut the older rocks in the district are probably related to this mass. The dikes are light colored and typically weather buff or pink. They are medium to fine grained and carry phenocrysts as large as 2 millimeters but averaging about 0.8 millimeter. The phenocrysts are composed of quartz and oligoclase, in a groundmass made up of quartz, oligoclase, and muscovite.

\section{TERTIARY ROCKS (MIOCENE)}

Remnants of lava flows are scattered over the divide between Elk and Deep Creeks and occur more continuously on the divide between Elk Creek and the Middle Fork of the John Day River. The lavas are much younger than any of the previously described rocks and are probably to be correlated with the Miocene Columbia River lava.

\section{QUATERNARY ROCKS}

The gravel along the streams and the slope wash and talus slopes of the hillsides represent the Quaternary period.

\section{STRUCTURE}

The schist enters the district from the west with an eastward strike. The general trend changes near the middle of the district, and the prevailing strikes in the eastern half are northeast, averaging approximately N. $50^{\circ}$ E. The dips are almost without exception steep to the south. A dip less than $50^{\circ}$ is seldom observed, and $70^{\circ}$ is common.

Only at the Princess mine was an observation taken on the schist immediately contiguous to the quartz diorite contact. Here the foliation is parallel to the contact, about N. $80^{\circ} \mathrm{W}$, and to the foliation of the quartz diorite. However, in the vicinity of the Gem mine, only a short distance from the quartz diorite contact, the trend of the schist is nearly at right angles to the contact.

The trends of the aplitic dikes are apparently parallel or nearly parallel to the trend of the country rock.

The nearly flat-lying patches of Miocene (?) lava on the steeply dipping schist series indicate a profound unconformity. The fact that the contact between lava and pre-Tertiary rock is found at altitudes that differ considerably from place to place suggests that the surface on which the lava was poured out had considerable relief, probably comparable to that of the present day.

\section{ORE DEPOSITS}

Most of the ore deposits of the district occur in fissure veins, chiefly parallel to the schistosity of the country rock. In a few prospects certain zones in some of the aplite dikes have been worked 
and are reported to carry gold and silver. Some of the mineralization appears to have produced very irregular replacement masses.

The deposits are all in the pre-Tertiary rocks. Most of them are in the schist series, but some are found in the basic rocks or at the contact of the basic rocks and the schist. No relation was found between the distribution of the ore deposits and the position of the main mass of the quartz diorite. However, many of the veins appear to be related to aplite dikes, which in turn are probably related to the quartz diorite. The common regional relation between the ore deposits of eastern Oregon and these quartz diorite masses makes this interpretation more reasonable.

The dominant gangue mineral of the veins is quartz. Ankerite and fuchsite are conspicuous in some of the veins. The metallic minerals determined from the study of polished sections are pyrite, marcasite, arsenopyrite, chalcopyrite, pyrrhotite, sphalerite, galena, stibnite, tetrahedrite-tennantite, and chalcocite. The paragenesis of the minerals, as concluded from the study, is shown in Figure 16. The time order of deposition is from left to right.

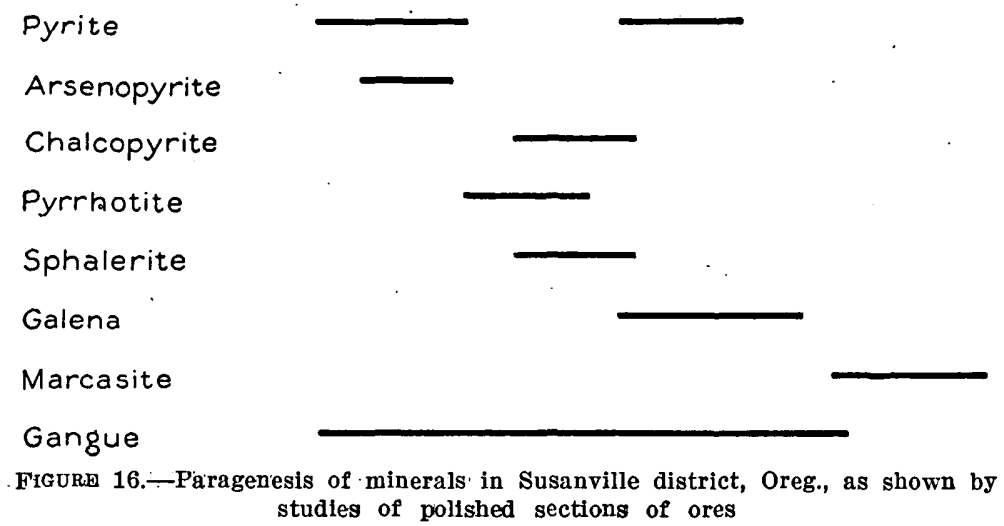

There was probably considerable overlap in the periods of deposition. Individual grains of pyrite are shattered and corroded, in places almost completely destroyed. Many of the fractures through this pyrite contain arsenopyrite, chalcopyrite, sphalerite, and gangue. That arsenopyrite was deposited later than part of the pyrite is further substantiated by the fact that there are numerous rounded fragments of pyrite isolated in the arsenopyrite.

The arsenopyrite in turn is fractured. 'These fractures commonly contain some chalcopyrite and sphalerite. Chalcopyrite is especially common but also occurs in angular spots scattered through the arsenopyrite. These spots finger off or pinch out gradually, as if the copper mineral had worked in along grain boundaries or minute 
cracks. A few small rounded pieces of arsenopyrite are entirely surrounded by chalcopyrite and sphalerite.

The paragenesis of the chalcopyrite, pyrrhotite, and sphalerite is confused, probably because of overlap. The sphalerite contains a great number of small spots of chalcopyrite, pyrrhotite, and locally, galena. In one specimen sphalerite is distinctly veined by pyrrhotite; in others sphalerite appears to penetrate and replace pyrrhotite along grain boundaries. Chalcopyrite is common in fractures and veinlets, through and around grains of pyrrhotite. In some places the chalcopyrite is veined by sphalerite. From this evidence it is thought that the pyrrhotite may be partly earlier than the chalcopyrite and the sphalerite, although in part, at least, they are contemporaneous.

Galena is considered younger than any of the previously described minerals except where the galena occurs in small spots in the sphalerite. Here these two minerals are probably contemporaneous. Considerable galena also occurs in the sphalerite in fractures and around holes; some is present in fractures through the pyrite. In many of the specimens rounded fragments of sphalerite are isolated in the galena.

There appear to have been two main periods in which pyrite was deposited. The first period began prior to and probably lasted during the deposition of the arsenopyrite. The second was at least later than the chalcopyrite and sphalerite. No pyrite has been observed cutting galena. Galena is not a very common constituent of the specimens, and such a relation might easily be missed. It is entirely possible that in the line diagram the period for deposition of pyrite should be represented as extending past the galena period.

It is also possible that there was one long period of deposition of pyrite instead of the two given. There is, however, no direct evidence to support this possibility.

... Stibnite has been omitted from the discussion of paragenesis because is was not seen in the same specimen with any other metallic minerals. It occurs in small radiating bunches of fine fibers or in small colloform masses. The material in which it was seen is vuggy and porous. The holes are lined with fine drusy quartz. Chalcedony is present in alternating layers with the stibnite. Tetrahedritetennantite was observed in only one specimen, from the Ophir mine, in which it replaces pyrite.

Later than any of the sulphides or metallic minerals is part of the gangue. Many of the specimens have been shattered and the fragments recemented by gangue. Gangue minerals have been observed transecting all the metallic constituents. 
There is no evidence of important supergene enrichment, although the few minor fissures and spots of chalcocite and marcasite were probably deposited by supergene waters.

\section{THE MINES}

\section{BADGER}

Location and development.-The Badger mine is in sec. 8, T. 10 S., R. $33 \mathrm{E}$., on the south side of Elk Creek. It is about 2 miles above the junction of Elk Creek and the Middle Fork of the John Day River. There are 12 patented claims in the Badger group.

The mine is owned by the Susanville Mines Co. Parks and Swartley ${ }^{52}$ say:

This vein was discovered in the late sixties, and in the early seventies free gold was extracted in an arrastre from the decomposed croppings, which yielded about $\$ 25$ per ton. Later on a 10 -stamp mill, with concentrators, was built, but there was not a high percentage of extraction.

As the result of litigation with the Stockton Mining Co. the mine was shut down in 1905 . There was some activity at the property in 1922 , but none since. The mine has produced in the past consideräble gold, silver, lead, and zinc.

The mine was originally opened by a shaft that was sunk 900 feet below the collar. Later a 1,600-foot crosscut was driven from a point about 30 feet above Elk Creek. This level is about 500 feet below the shaft collar, or 400 feet above the bottom of the shaft. The shaft has caved above the crosscut level and is inaccessible. The crosscut, however, is open, furnishing access to about 3,000 feet of drifts and several winzes and raises. The workings are flooded nearly to the main crosscut level.

Geology.-The predominant country rock is slate, but shale, schist, and quartzite are also present. The strikes are uniformly east and the dips range between $55^{\circ}$ and $60^{\circ} \mathrm{S}$.

Gouge and breccia along the planes of schistosity suggest strike faulting. This appears to be common throughout the district. The south side appears to be the downthrown side:

The veins conform to the strike and dip of the country rock. At least two veins have been stoped. These veins are about 6 feet apart and range in width from 1 foot to 20 feet. Fragments of wall rock are contained in the veins. In some places the veins appear to be at least in part replacement bodies in that "ghosts" of wall rock are present.

\footnotetext{
62 Parks, H. M., and.Swartley, A. M., Handbook of the mining industry of Oregon : Mineral Resources of Oregon, vol. 2, No. 4, p. 19, Oregon Bur. Mines and Geology, 1916.
} 
The vein material is predominantly quartz. Much ankerite is also present. The most common sulphide is pyrite. Locally galena, sphalerite, or arsenopyrite may predominate.

GEM

Location and development.-The Gem mine is on the west side of Elk Creek near its head. It lies in sec. 5, T. 10 S., R. 33 E.

The vein is opened by an inclined shaft, which is now filled with water within 50 feet of the surface. The shaft is reported to be 350 feet deep and to have four levels turned from it.

B. F. Hurt, who is at present in charge of the property, states that most of the stock of the Gem Mining Co. is controlled by Gus Smith but that the ground has been leased to a Spokane company. The property consists of four claims, two of which are patented.

Parks and Swartley ${ }^{53}$ say that

Seventy-five to a hundred tons have been milled elsewhere and a few tons shipped crude. *** The property was closed down in 1909 , but in September, 1916, a carload of crude ore was sorted and shipped to smelters.

According to a report by Carl Anderson, a mining engineer of Portland, 13 tons of ore has been shipped to smelters. Some development work was done in 1922.

Geology.-The country rock is talc schist and altered peridotite. At the surface the peridotite marks the footwall and the schist the hanging wall of the vein. At the water level in the shaft both walls are schist. Serpentine is reported below the water level. The contact of the peridotite and the schist was not traced, but the strike of the schist is $\mathrm{N} .45^{\circ} \mathrm{E}$. and the $\operatorname{dip} 62^{\circ} \mathrm{SE}$. at the shaft collar.

The vein, which is about 3 feet thick, corresponds in attitude to the strike and dip of the schist. In a small gulch just below the Gem shaft another vein, which strikes N. $40^{\circ}$ E. and dips $60^{\circ} \mathrm{SE}$., crops out. If these strikes and dips persist these veins intersect north of the shaft.

The vein consists of quartz with subordinate ankerite. It carries some free-milling gold. Chalcopyrite, pyrite, and pyrrhotite were seen on the dump.

\section{BULL OF THE WOODS}

The Bull of the Woods mine is owned by the Susanville Mines Co., the same company that owns the Badger. The workings are just east of the Badger mine but are on the north side of Elk Creek.

The mine has been opened by two adits and a vertical shaft that connects the adits. The shaft is about 100 feet from the portal of the upper adit. The upper level is caved beyond the shaft but is

${ }^{\text {ss }}$ Parks, H. M., and Swartley, A. M., op. cit., p. 164. 
reported to have been 1,500 feet long. The lower level consists of about 220 feet of drifting.

A small production was reported from the mine in $1905 .^{54}$

The country rock is serpentine and talc schist. A little aplite and greenstone were also seen. The country rock is broken and shattered, and alteration has converted much of it to sericite and clay.

The vein is not visible in the upper workings, but it is reported to strike slightly east of north and to dip steeply east. No definite vein was followed in the lower level. The work has been done in the shattered altered area containing quartz, ankerite, sericite, serpentine, limonite, hematite, and some pyrite.

RESCUE

The Rescue group consists of three claims owned by Charles Ray of Susanville. The property adjoins the Gem ground on the west.

There is an inclined shaft on the property, at present full of water, which is reported by Mr. Ray to be 140 feet deep. A tunnel, now about 200 feet long, has been started below the shaft. It is planned to continue this tunnel until the vein is intersected. No production has been reported from this group.

The country rock is schist.- The strike of the main vein ranges from north to N. $10^{\circ}$. E. The dip is uniformly about $60^{\circ} \mathrm{E}$. Three other smaller veins exposed on the surface strike about N. $30^{\circ} \mathrm{E}$. and $\operatorname{dip} 60^{\circ}$ E. Quartz is the predominant gangue mineral, but ankerite is rather common. The ore minerals found on the dump were pyrite, sphalerite, pyrrhotite, chalcopyrite, galena, and arsenopyrite.

\section{Chațtanooga}

The Chattanooga property consists of one patented claim lying southwest of the Rescue group. It is owned by B. F. Hurt of Susanville. The property is opened by a vertical shaft, filled with water but reported to be 210 feet deep. A little ore has been shipped in the past.

The country rock is talc schist. The vein strikes N. $65^{\circ} \mathrm{E}$. and dips $60^{\circ} \mathrm{E}$. The predominant gangue mineral is quartz, but ankerite, mariposite, and sericite are present. Massive sulphides were found on the dump and include pyrite, chalcopyrite, sphalerite, galena, and arsenopyrite.

\section{DAISY}

The Daisy claim, owned by B. F. Hurt, of Susanville, lies just south of the Rescue group.

The country rock is talc schist. Two small open cuts expose a small vein, which strikes N. $20^{\circ}$. E. and dips about $65^{\circ}$ E. The

ss U. S. Geol. Survey Mineral-Resources, 1905, p. 291, 1906. 
gangue is rusty quartz. Small amounts of sulphides; chiefly pyrrhotite, pyrite, and chalcopyrite, occur in the quartz. Mr. Hurt says that the value is mostly in free gold.

\section{PRINCESS}

The Princess property is on the south bank of Deep Creek in sec. 31 , T. 9 S., R. 33 E. It is reached by means of the Princess trail, .which leads over the divide from the Gem mine. The property consists of two claims owned by Charles Ray, of Susanville.

The workings consist of an adit about 400 feet long, a 60-foot shaft, and a small open cut. There has been no production. (See fig. 17.)

The mine is in the schist series very close to its contact with the main mass of quartz diorite. The country rock is talc schist, quartz diorite, and quartz-biotite schist.

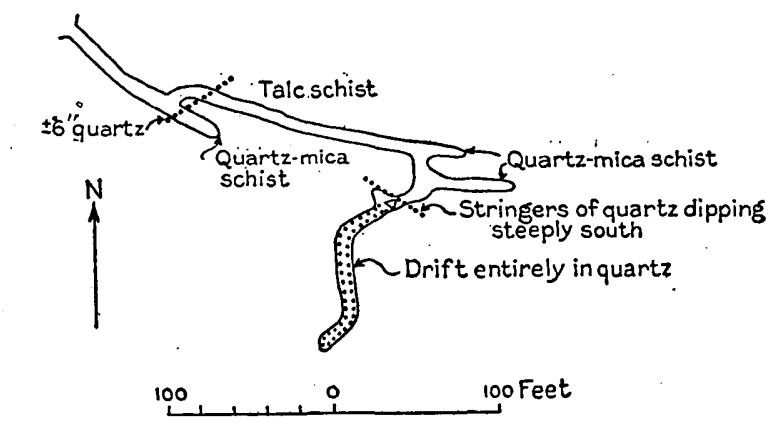

Figdri 17.-Map of Princess prospect, Susanville district, Oreg.

There are several small veins and stringers running in different directions, but most of the work has been done in what appears to be a nearly vertical irregular pipelike mass of quartz. Stringers extend from the mass in several directions. This is probably, at least in part, a replacement mass, for the wall rocks have been intensely silicified, and separated schist layers and ghosts of wall rock are common in the quartz. The massive quartz has a light-blue watery appearance. A few small amphibole crystals are dispersed through it, and it is locally seamed with stringers of sericite. According to Mr. Ray, the ore is richest at the shaft near the north end of the quartz body. Pyrite, chalcopyrite, pyrrhotite and sphalerite were the metallic minerals seen. Mr. Ray also reports some free gold.

\section{POORMAN}

$\therefore$ The Poorman group or Dougherty property consists of seven patented claims, all owned by Robert-Dougherty, of Susanville. 
The claims lie east of the Badger mine, on the north side of Elk Creek. There are numerous old adits and shafts on the hillside, most of which are caved and inaccessible. About 300 feet of drift is open. Mr. Dougherty reports that there has been a small production of free-milling gold.

The country rock is talc schist with some slate. The schist series is cut here by an aplite dike about 50 feet thick. The dike appears to be vertical and strikes a little west of north. A-vertical zone, striking $\mathrm{N} .60^{\circ} \mathrm{E}$., in the aplite is now being worked.

The veins are all small stringers, but they are reported to be rich. The gangue minerals are predominantly quartz and ankerite. The

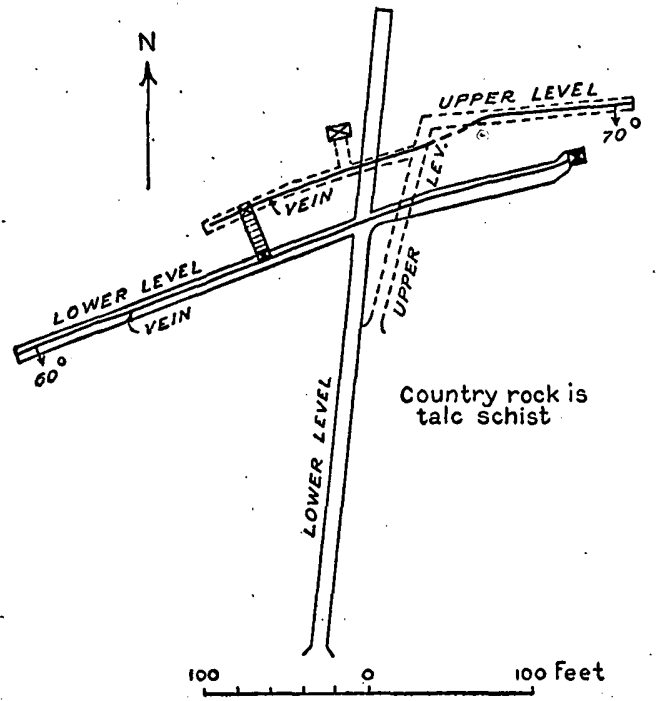

Figure 18.-Map of workings, Belle of the Hills prospect, Susanville district, Oreg. sulphides seen in clude sphalerite, pyrite, galena; chalcopyrite, and stibnite.

\section{BELLE OF THE FILLS}

The Belle of the Hills property, owned by Norman. Jøhnson, of Susanville, is composed of three claims that lie directly west of the Badger mine.

The mine consists of two levels, the upper about 55 feet above the lower. (See fig. 18.) The upper level is opened by an adit about 130 feet long and has about 300 feet of drift. The lower adit is 380

feet long. There is about 370 feet of drift in the lower level. The two levels are connected by a 60 -foot incline. On the hillside above the mine are several small shafts and open cuts. No production has been reported.

The country rock is talc schist and slate. The strike is in general east, and the average dip is about $70^{\circ} \mathrm{S}$. The workings cut several small seams of quartz, but nearly all the work has been confined to one vein, which strikes $\mathrm{N}$. $70^{\circ} \mathrm{E}$. and dips $60^{\circ}-70^{\circ} \mathrm{S}$. The vein ranges from 6 inches to 1 foot in width and contains considerable quartz and pyrite. According to Mr. Johnson, some of the quartz stringers encountered in the open cuts show free gold in the pan.

\section{GOLD BUG}

The Gold Bug prospect, owned by Messrs. Leahy and Dunstan, of Susanville, is near the crest of the ridge about a mile northeast 
of Susanville. The workings are inaccessible. According to Charles Ray, the shaft is about 400 feet deep. The mine has been abandoned for years, and no production was reported.

The country rock is talc schist that strikes N. $50^{\circ} \mathrm{E}$. and dips $70^{\circ}$ $\mathrm{SE}$. The poor outcrops near the shaft collar indicate that the vein conforms to the strike and dip of the schist. Some carbonate was seen in the iron-stained quartz on the dump.

\section{MOCKING BIRD}

The Mocking Bird property is on the north side of Elk Creek just across from the Badger. It is controlled by the same company that owns the Badger. The workings consist of a small open cut and a tunnel that is now inaccessible.

The talc schist country rock is cut by a large aplite dike. The vein, consisting of 6 inches of quartz and gouge with considerable jarosite, follows close to the schist-aplite contact but is confined to the schist. The strike of the vein is N. $10^{\circ} \mathrm{E}$., and the dip is $70^{\circ} \mathrm{SE}$. On the dump were found pyrite, sphalerite, chalcopyrite, pyrrhotite, and a little galena.

\section{OPHIR}

The Ophir mine lies south of the Badger.shaft on the slope toward the Middle Fork of the John Day River. The property consists of one claim which is developed by a shaft and several adits. Of these only one small adit, 290 feet long, is accessible. A little ore was shipped to the Tacoma smelter in 1908.

The country rock is talc schist and slate. The strike is N. $55^{\circ} \mathrm{E}$., and the dip $55^{\circ} \mathrm{SE}$. Several small quartz and carbonate stringers parallel the schistosity. Pyrite, chalcopyrite, and tetrahedrite-tennantite were the metallic minerals observed. Some aplite occurs in the accessible adit.

\section{BLACKHAWK}

The Blackhawk property, like the Badger, is owned by the Susanville Mines Co. It lies east of the Bull of the Woods, on the southeast side of Elk Creek. The property is opened by a shaft inclined at $60^{\circ}$. The shaft is reported to be 150 feet deep, but it is filled with water within about 40 feet of the surface.

The country rock is talc schist. The vein consists of a 6-inch stringer of quartz and gouge with some pyrite, galena, and sphalerite. The vein strikes $\mathrm{N} .70^{\circ} \mathrm{E}$. and dips $60^{\circ} \mathrm{S}$.

SIDE ISSUE

The old mine known as the Side Issue is on the Blackhawk property. All the workings are inaccessible. Outcrops of talc schist and serpentine were seen near the shaft. 


\section{sIMcox}

The Simcox property is half a mile east of the Blackhawk prospect. It is owned by Mrs. Gertie O'Rourke, of Susanville. The workings consist of an adit 516 feet long and three small drifts branching from the end of the adit. The country rock is talc schist. The workings cut but do not follow several small quartz stringers.

The Skyscraper property lies on the top of the ridge between Elk and Deep Creeks, above the town of Galena. The property consists of one claim. There has been considerable work done in the past, but only a small cut is now accessible. The country rock is talc . schist. A small vertical vein strikes N. $85^{\circ} \mathrm{W}$. According to Norman Johnson, $\$ 3,000$ worth of gold was taken from a small pocket in this vein.

\section{THOMPSON}

The Thompson Mining Co., controlled by C. A. Thompson, owns eight claims on the north side of Elk Creek a short distance below the Badger. The property is developed by a 900 -foot prospect adit, which runs $\mathrm{N} .30^{\circ} \mathrm{E}$. near the portal but turns near the face and runs $\mathrm{N} .70^{\circ} \mathrm{E}$. The country rock is talc schist and slate. Several small stringers of quartz and gouge have been cut. These strike N. $80^{\circ}$ E. and $\operatorname{dip} 60^{\circ} \mathrm{S}$., paralleling the schistosity.

\section{STOCKTON}

The Stockton property consists of three claims lying southeast of the Badger property. The country rock is slate. There has been some work done in the past, but it is now inaccessible.

\section{NELSON}

Guy Nelson, of Susanville, owns some claims at the junction of .Elk Creek and the Middle Fork of the John Day River. At the time of the writers' visit a small inclined shaft, reported to be 25 feet deep, was filled with water. The country rock is talc schist. The schist, which contains seams of pyrite and marcasite both parallel to and cutting the schistosity, is reported to carry gold.

\section{PLACER MINES}

The Susanville placers were all inactive at the time of visit. Swartley ${ }^{55}$ says :

The placer mines of Susanville were discovered in 1864, and have been worked practically every season since then.

\footnotetext{
${ }^{55}$ Swartley, A. M., Ore deposits of northeastern Oregon: Mineral Resources of Oregon, vol. 1, No. 8, pp. 169-170, Oregon Bur. Mines and Geology, December, 1914.
} 
Elk Creek has produced the most, but other creeks lower down, along the north side of the John Day, have also yielded considerably. The total placer production is approximately $\$ 600,000$.

The Middle Fork, below Elk Creek, is reported to have produced $\$ 50,000$ in fine flour gold, but the creeks usually contain coarse gold, 0.865 fine.

The largest gold nugget found on Elk Creek during the more active operations was worth $\$ 480$. Deep Creek had one worth $\$ 625$. Buck Gulch, below Deep Creek, years ago had one worth $\$ 800$, but on June 19, 1913, George Armstrong found another on Buck Gulch weighing 80.4 ounces, which at $\$ 17.60$ per ounce would be worth $\$ 1,415$. Most of the gold in the Elk Creek placers seems to have come from the west side of the creek, although the most productive quartz mine is on the other side.

Considerable drifting has been done near the Middle Fork of John Day underneath the basalt capping, in hopes of cutting old stream channels in the search for placer gold, but such operations have not been successful because they have as yet been unable to cut through the rim-rock to enter these old channels anywhere near the bedrock.

The Middle Fork from a point somewhat above Elk Creek downstream for a distance of 4 or 5 miles, was partially prospected in 1898 with a view to dredging, but nothing came of it. In this same ground in 1913 the entire valley for this distance was under option, and test pits were sunk at various points. The results of these shafts are said to average 14 or 15 feet in depth and to contain sufficient value to warrant a systematic drilling of the ground with a view to the installation of a dredge.

No dredging had been carried out on this ground, however, prior to the time of this survey.

\section{OUTLOOK FOR THE DISTRICT}

The Susanville district is handicapped by the long distance to a railroad. As can be noted in the preceding descriptions, there are several veins whose prospects. would justify considerable development in a less isolated district. The ore of the district is not amenable to amalgamation, and the tenor of concentrates must be high to overcome the transportation charges. With one or two possible exceptions the profits won from the mines of the district in the past were derived from the placers and from pocket hunting on a small scale. Until a satisfactory extraction process is applied to the ores or the transportation costs are notably.lowered it must be confessed that little hope for enlarged activity can be justified. This district; were it located more favorably, would probably have a creditable record of production but under present conditions its development will probably be slow.

\section{OCHOCO DISTRICT}

\section{GEOGRAPHY}

The Ochoco quicksilver district occupies an irregular belt extending about 40 miles in a northeasterly direction from a point about 
20 miles due south of Prineville to the divide at the head of Ochoco: Creek, about $10^{\circ}$ miles southwest of Mitchell. . Most of the deposits. discovered up to 1930 are in Crook County, but at least one prospect. is just over the boundary in Wheeler County. (See fig. 19.)

The area lies at the west end of the westward-trending Ochoco. Mountains, almost entirely in the drainage basin of the Crooked River. Altitudes range from about 6,600 feet on Lookout Mountain

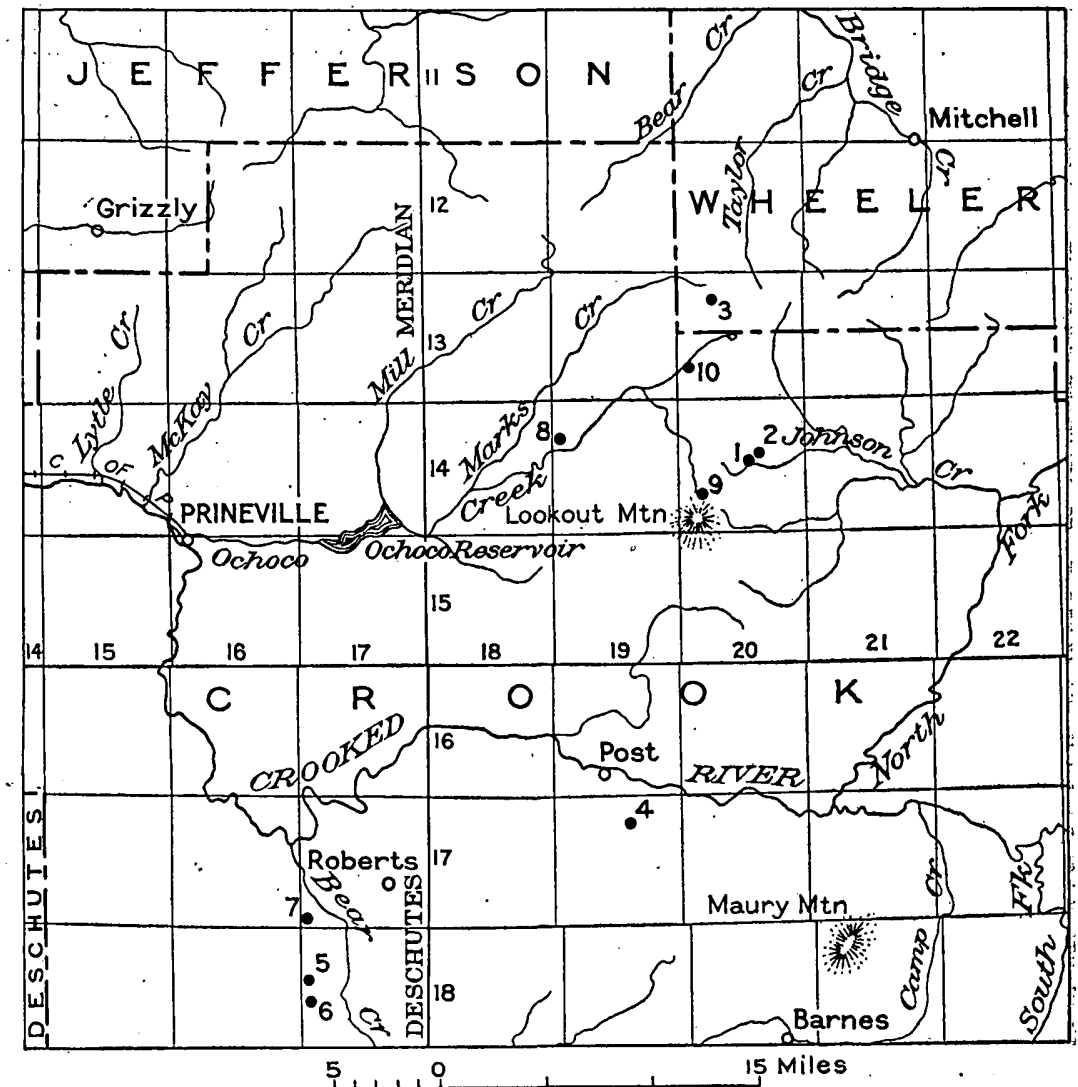

FIgURe 19.-Map showing location of deposits in the Ochoco district, Oreg., described in this report

to about 2,000 feet near Prineville. The climate is arid, but the rainfall suffices to support open pine forests on the higher ground, though only sagebrush and juniper are prominent in the lower country.

Most of the quicksilver deposits are readily. reached by way of the Ochoco Highway, which extends from Prineville to Mitchell, or by the Crooked River Highway, from Prineville to Post. Prineville itself is connected by the City of Prineville Railway to the Oregon. Trunk Line of the Great Northern system at Prineville Junction, in the Deschutes Valley. 
THE MINES

\section{JOHNSON CREEK-LOOKOUT MOUNTAIN AREA}

Paulsen \& Saylor.-The Paulsen \& Saylor mine is just north of Johnson Creek in sec. 15, T. 14 S., R. 20 E., Willamette base and meridian. It is reached by way of a forest road that leaves the Ochoco Highway a short distance east of the Ochoco ranger station and passes southeast, over the divide north of Lookout Mountain. It is about 30 miles by road from Prineville.

The deposit was discovered in 1929 by W. J. Westerling, who leased the property to Martin Paulsen and Evan Saylor in April 1930. A small retort was erected in the summer of 1930, but no actual production had been made at the time of visit, in August.

The property is developed by means of a shallow open cut and, about 60 feet lower, by a crosscut that trends $\mathrm{N} .30^{\circ} \mathrm{W}$. and is about 120 feet long.

The country rock is rhyolite probably of Tertiary (Clarna?) age. It is highly altered near the veins. In the open cut the rhyolite is intersected by joints that strike N. $60^{\circ}$ E. and dip $60^{\circ} \mathrm{N} . \mathrm{W}$. In the crosscut a northward-trending fault which dips $75^{\circ} \mathrm{W}$. is cut. A quartz vein 8 inches or less thick is developed along this fault and is itself brecciated slightly by later movements.

These faults and fissures are the sites of mineralization, chiefly the development of seams of quartz, chalcedony, and opal, containing impregnations of cinnabar and a little pyrite. Calcite accompanies the quartz, and small vugs in the veinlets are filled with an asphaltlike hydrocarbon. The wall rock along these fissures is intensely altered, chiefly to clay (probably a ferriferous montmorillonite) and nontronite but with local silicification. The cinnabar disappears gradually away from the central fissures.

The clay zone containing cinnabar impregnation is about 6 feet wide where exposed in the open cut, but nothing definite is known of its persistence, as it is not established that the vein cut in the lower workings is the same.

Westerling.-The W. J. Westerling prospect is situated on a small north branch that joins Johnson Creek about half a mile below the Paulsen \& Saylor mine. The prospect is in a wide parklike area in the creek bottom, where no bedrock crops out. The deposit was located by hand drilling and panning. Cinnabar occurs in a belt reported by Mr. Westerling to be about 70 feet wide and to trend $\mathrm{N}$. $45^{\circ} \mathrm{E}$. A few open cuts have been dug along this belt to a depth of about 10 feet. In the only accessible one of these cuts there is a little cinnabar in stringers in the residual soil resulting from the decomposition of an augite-hypersthene andesite, presumably of 
Clarno age. A little chrysocolla occurs with the cinnabar. Not enough work had been done here to gain any adequate idea of the possible extent or value of the deposit.

Quicksilver Consolidated Mining Co.-The mine of the Quicksilver Consolidated Mining Co. is in sec. 29, T. 14 S., R. 20 E., on the north slope of Lookout Mountain about 2 miles from the Johnson Creek road and about 30 miles from Prineville by the Ochoco Highway. The mine was under the management of C. W. Washburne at the time of visit.

The property, formerly known as the American Almaden, has been exploited intermittently for many years, but the total production, according to Mr. Washburn, probably does not exceed 50 flasks. Three flasks were produced in 1906 and small amounts in $1908,1915,1929$, and 1930 . There is a rather elaborate retort on the property.

The mine is developed by two tunnels. Several other surface workings are caved. At the time of visit work was confined to the lower level. This level contains about 1,500 feet of drifts, one raise to the upper level for ventilation, and several minor raises. Some stoping has been done in three places. (See fig. 20.). The ground is very heavy, and most of the work is completely lagged. Square sets are used in the stopes.

The country rock is Tertiary (?) basalt, cut by some diabase dikes. The deposit consists of a network of veins in the shattered basalt. The veins can hardly be described as having any definite course; they are commonly small, branching, irregular stringers and seams. Locally the stringers tend to follow stronger controlling fissures and send out branches from these in all directions. One vein that had been worked just prior to the visit strikes $\mathrm{N} .45^{\circ} \mathrm{W}$. and stands vertical. This vein or lode is apparently controlled by a shear surface and ranges in width from 3 inches to about 1 foot. Many narrower stringers branch from it into the northeast wall, but the southwest wall, in the exposed workings, seems to be less mineralized. These stringers range in thickness from a knifeedge to about half an inch, but most are less than one eighth inch thick.

The basalt, where cut by these fissures, is intensely altered to clay (chiefly ferriferrous montmorillonite), with a little chlorite developed along stringers. These chloritic stringers are cut by the cinnabar-bearing fissures, which are locally crustified with opal, chalcedony, quartz, dolomite, a little calcite, and some asphalt accompanying the cinnabar. Pyrite has impregnated the zone of clay alteration and appears to be older than the cinnabar-bearing. 164495-33-9 
stringers. The sequence of mineralization appears to be first clay, chlorite, and pyrite followed in order by quartz, cinnabar, quartz and dolomite, chalcedony and opal, and lastly, asphalt.

Considerable stoping has been done near the end of the northeast drift, a stope there in gougy basalt being about 40 feet high and 15 to 20 feet wide. A little cinnabar remains in the clay of the

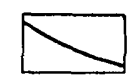

Mineralized shear zone

Note: Country rock chief.

ly altered basalt with some

diabase dikes.

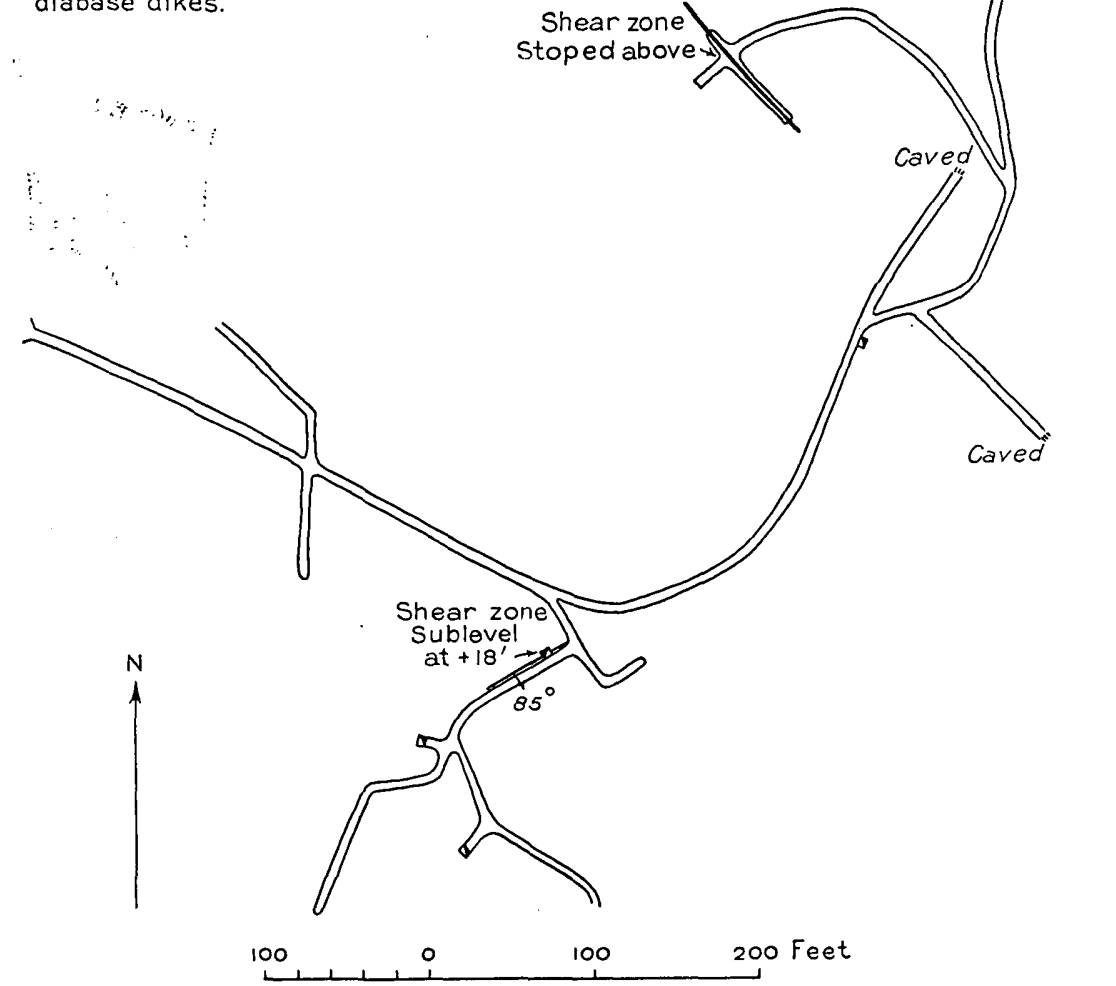

Frgurn 20.-Main level, Quicksilver Consolidated Mining Co.'s mine, Ochoco district, Oreg.

walls. Several other stopes have been worked; one, near the junction of the southwest branch with the main drift, is about 50 feet long and follows a vein that strikes N. $60^{\circ}$ E. and dips steeply south. This stope extends to the upper level. Much of the old work in the mine is caved, so that the extent of other stoping was not determined.

The tenor of the ore is unknown, but to judge from the material exposed in the mine it must be rather low. It would be difficult to select any considerable tonnage carrying more than one half of 1 
per cent of quicksilver; probably even this limit would be hard to maintain.

MARKS CREEK AREA, WHEELER COUNTY

Bear.-Carl Fisher and G. L. Brazee have located a group known as the Bear claims near the head of Marks Creek, in the southwest corner of Wheeler County. The claims are reached by a 2-mile forest road, which leaves the Ochoco Highway at the divide between Ochoco Creek and Bridge Creek. The distance from Prineville to the property is about 30 miles.

The deposits were discovered in the spring of 1930, and but little work had been done up to the time of visit in August. A 35-foot inclined shaft and a few open cuts constituted the development work.

At the shaft the country rock is Tertiary (?) olivine andesite, cut by a 4 -inch quartz vein that strikes N. $55^{\circ}$ E. and dips $65^{\circ} \mathrm{NW}$. The walls of the vein have been impregnated with cinnabar and a little pyrite, both along branching veinlets and in the massive rock. The impregnation disappears within a short distance from the vein and is not marked a foot or so from it. Quartz, chalcedony, opal, dogtooth calcite, dolomite, and clay minerals accompany the cinnabar, and vugs in the vein are filled with hydrocarbons. Some of the cinnabar seems to be later than the quartz, but most is earlier. Replacement of the wall rock is evident, with "ghosts" of wall rock in the quartz. Jarosite and other limonitic products of oxidation are present.

About 1,000 feet northeast of the shaft a 2 -inch vein of chalcedonic quartz carrying a little cinnabar has been exposed in a surface cut in olivine basalt. The vein strikes $\mathrm{N} .80^{\circ} \mathrm{W}$. and dips $70^{\circ} \mathrm{N}$. About 500 feet farther northeast is another outcrop of quartz much stained with limonite but not showing any cinnabar at the surface.

Sufficient work had not yet been done to demonstrate the value of the property.

\section{OCHOCO CREEK AREA}

By G. F. Loughlin and James Gilluly

The Ochoco Creek area is conveniently described in two parts-the Champion mine, which has produced quicksilver, and Gold Hill and vicinity, where gold and silver have been produced.

\section{CHAMPION}

The Champion mine is half a mile north of the Ochoco Highway in the Ochoco Creek Valley, in sec. 7, T. 14 S., R. 19 E. It is about 20 miles from Prineville. It was located by A. J. Champion and is owned by A. J. Champion, A. Barney, and J. E. Staley. Negotiations for its acquisition by a group of Portland capitalists were reported as being just completed at the time of the writers' visit to the property in August, 1930. 
The mine is developed by an inclined shaft about 125 feet deep and a tunnel 400 feet long. Work was going forward to connect the tunnel and shaft. There is a short sublevel at a depth of 45 feet, from which stoping was going forward, and a number of small open cuts between the shaft and the adit of the tunnel were also driven on the outcrop of the ore body. The total development work at the time of visit would not aggregate more than 700 feet. A crude retort handling about a ton a day was in operation at the time of visit.

The country rock is andesite, probably of Tertiary age. It is cut by several faults and fissures; the most prominent one, along which the ore body occurs, is a shear zone that trends N. $45^{\circ}-55^{\circ} \mathrm{E}$. and dips $50^{\circ}-65^{\circ} \mathrm{SE}$. Along this zone the rock has been intensely and almost entirely altered to a slickensided clay, chiefly a ferriferous montmorillonite, with some kaolin and nontronite. Impregnating this clayey zone and roughly following the most prominent shear are cinnabar, pyrite, calcite, opal, and chalcedonic quartz. These minerals occur both as veinlets in the altered rock and as discrete particles sporadically developed in it. It can hardly be said that any vein system is present; the mineralized body seems to be a crushed zone. However, the best ore seems to occur rather constantly along the most prominent fault wall. In the stope from which the retort ore was being extracted at the time of visit, just west of the shaft on the 45-foot level, a stringer of cinnabarbearing material about 4 inches wide occured along this wall, from which the cinnabar seemed to fade out in smaller and smaller veinlets into the clay walls. Cinnabar occurred across the entire face of the drift, about 5 feet wide, but only the high-grade streak was being sent to the retorts.

The lower tunnel, through a combination of circumstances, was not accessible at the time of visit to the property. It is reported to show a number of cinnabar veins, but work was not being done on them pending completion of the connection with the shaft.

No precise information as to the tenor of the ore was available. However, in the crude retorts that were being operated about a flask of quicksilver was being recovered every 24 hours, from about 2,400 pounds of crude ore. As it was easy to pan considerable cinnabar and free quicksilver from the tailings, the recovery is obviously far from satisfactory. The ore as roasted must clearly run in excess of 5 per cent. As very little powder is required to break the ore, most of which was being dug with a clay digger, the property offers considerable promise of cheap production.

GOLD HILL AND VICINITY (HOWARD DISTRICT)

Location and topography.-Gold Hill is crossed by the boundary between secs. 29 and 30, T. 13 S., R. 20 E. It is 26 miles east of 
Prineville and 8 miles northeast of Howard, the nearest post office, on the main highway across central Oregon. The area, as shown in Plate 8, consists of rounded, timber-covered hills drained by Ochoco Creek and its local tributaries, which follow prevailingly northwesterly courses. The largest tributary, Scissors Creek, is the chief site of local small placer mining. Gold Hill, the principal mineralized area, occupies the angle between Ochoco and Scissors Creeks and has an altitude of 4,800 feet. The highest altitude in the vicinity, 6,450 feet, is that of Round Mountain, 2 miles southeast of Gold Hill. The only local settlement is Ochoco camp, at the west base of Gold Hill. It has been only intermittently occupied for several years.

Production.-Records of discovery and production are incomplete. The earliest record mentioned in the Mint reports on gold and silver production shows an output of $\$ 10,000$ in gold during 1885 , but from 1886 to 1896 annual records ranged from nothing to estimates of $\$ 1,600$ in gold. The only mention of silver production stated a value of $\$ 50$ in 1889. No record of production from 1897 to 1902 inclusive has been found. More accurate records have been kept since $1903^{56}$ and show an intermittent production amounting to 536.80 fine ounces of gold and 79 ounces of silver from placers, and 2,225 tons of crude ore from which $2,478.35$ fine ounces of gold, 442 fine ounces of silver, and 2,662 pounds of lead were recovered. The latest production recorded was in 1923. The total value of gold produced, according to all available records, is $\$ 79,885$. Of this $\$ 17,560$ is based on estimates prior to 1902 and $\$ 62,325$ is based on records since 1902 .

Geology.-The following sketch of the local geology and ore deposits is written by G. F. Loughlin, who spent six days in the area in 1914. The principal mine workings were inaccessible, and no mining or prospecting was going on in 1930.

The bedrock consists of volcanic flows and breccias which, according to R. W. Richards, ${ }^{57}$ of the United States Geological Survey, are tentatively correlated with the Clarno formation, of early Tertiary age (upper Eocene and lower Oligocene). These rocks have been gently uplifted and are flanked in the surrounding country by horizontal flows of later Tertiary basalt. The Clarno (?) formation is locally divisible into two parts, the lower characterized mainly by hornblende andesite and the upper by olivine basalt. It is possible that the basalt is of post-Clarno age and may be correlative with the Columbia River lava. The distribution of these rocks, so far as determined by a few traverses radiating from Gold Hill, is shown in Plate 8. They dip at low angles but are so exten: sively covered by soil and débris that a detailed study would be necessary to determine their exact sequence and structural relations. The

${ }^{86}$ Supplied by V. C. Heikes, U. S. Bureau of Mines, San Francisco, Calif.

"Personal communication, 1931. 
part of the area that contains the gold deposits is underlain by the lower or andesite group. Dense or finely porphyritic andesite underlies the valley of Ochoco Creek and the western slope of the ridge containing Gold Hill. This is bordered on the southeast and apparently underlain by a more coarsely porphyritic andesite, which in turn is underlain by a poorly exposed andesite breccia in the 'valley of Scissors Creek. The porphyritic and overlying dense andesites are also present on the spur called Red Bird Hill, south of Scissors Creek, where the breccia is locally separated from the porphyritic andesite by a dike of dense andesite. The flow of dense andesite is apparently overlain by another porphyritic hornblende andesite that caps Bear Point. Half a mile to the northeast dense andesite is overlain by a porphyritic hypersthene-augite andesite whose relations to the hornblende andesite of Bear Point were not determined.

The hypersthene-augite andesite is overlain by a dense to vesicular olivine basalt that forms the basal part of the upper member. This basal part is overlain by a cliff-forming breccia which is in turn covered by the thick olivine basalt, similar to the basal part that forms the main mass of Round Mountain. The upper member is cut by many dikes of basalt characterized by poorly shaped black phenocrysts of augite. These dikes are most conspicuous in the breccia, where they tend to weather in relief. It is not known whether they are directly related to the upper member of the Clarno (?) formation or are to be correlated with the later basalts that flank the Clarno (?).

The nearest observed flow of the later basalt in the vicinity of Gold Hill caps McAllister Butte, a small hill $11 / 2$ miles to the north. Remnants of the same flow may cap the ridge west of Ochoco Creek, and several dikes of similar basalt are present on the eastern slope of this ridge.

The most prominent structural feature, besides the general low angle of the dip, is fissuring. Of the fissures noted within the intensely mineralized area more trend $50^{\circ}-70^{\circ} \mathrm{W}$. than in any other direction; others trend approximately east, N. $25^{\circ}-60^{\circ}$ E., and south. Nearly horizontal fissures are also numerous and of special interest in ore hunting, as some of the rich "ore pockets" have formed along them. Narrow crushed zones, as much as 2 feet in thickness, are conspicuous along fissures in each of these systems, and the impression is gained that although the N. $50^{\circ}-70^{\circ} \mathrm{W}$. system predominates, its fissures are intersected or joined by so many fissures of the other systems that the ground is broken into a complex of blocks, each of which was moved slightly during the local uplift. The fissures were mostly formed before ore deposition took place, but one pronounced postmineral fissure was noted near the breast of the Ophir- 
Mayflower tunnel, and slight postmineral renewals of movement have taken place along many of the premineral fissures.

The northwesterly and roughly parallel courses of the tributaries of Ochoco Creek accord with the trend of the prevailing fissure system.

Ore deposits.-The ore deposits seen by the writer are confined to Gold Hill, Red Bird Hill, and the parts of Ochoco and Scissors Creeks that receive the drainage from these hills. Other deposits are doubtless present near the area studied-for example, a production of about 3 ounces of gold was reported in 1893 from the Last Chance mine, which is $11 / 2$ miles south of Gold Hill near the southeast corner of sec. 31 , and an assay value of $\$ 45$ is said to have been obtained from a small prospect in altered andesite on the south slope of McAllister Butte, 11/2 miles north of Gold Hill-but so far as known almost the entire gold production of the area and of Crook County as a whole has come from Gold Hill and the immediate vicinity.

The mineralized ground consists of intensely altered andesite cut by narrow veinlets, commonly an inch or less thick, which locally enlarge into high-grade ore shoots, especially at junctions or intersections. The largest shoot in the Ophir-Mayflower mine was mined for a vertical distance of 250 feet, a horizontal distance of 70 feet, and a width of 1 to 6 feet. ${ }^{58}$ The intensely altered rock is bleached. Its groundmass is slightly to considerably silicified, and its phenocrysts and unsilicified groundmass are replaced by mixtures of carbonates, chlorite, and the clay mineral montmorillonite, with which some sericite may be associated. Both phenocrysts and groundmass are impregnated by scattered minute crystals and short hairlike streaks of pyrite, and the rock as a whole is so full of small cracks containing films of vein material that it.has been regarded as mill ore. The intensely altered rock is confined to Gold Hill and the lower slope of Red Bird Hill. It grades outward into unbleached rock that has been impregnated to a considerable degree by carbonates and chlorite and inconspicuous amounts of the other secondary minerals.

The original minerals of the veinlets are carbonates, quartz, and pyrite, with locally conspicuous amounts of arsenopyrite, zinc blende, chalcopyrite, tetrahedrite, and galena. Alteration products in the rich sulphide ore include sooty chalcocite, clusters of fine needles of jamesonite (?), a little valentinite $\left(\mathrm{Sb}_{2} \mathrm{O}_{3}\right)$, andorite $\left(2 \mathrm{PbS} . \mathrm{Ag}_{2} \mathrm{~S}_{3} 3 \mathrm{Sb}_{2} \mathrm{~S}_{3}\right)$, and a dark-red mineral resembling ruby silver, besides veinlets and druses of colorless calcite and quartz. Brown iron oxide and black manganese oxide are the principal constituents of the oxidized ore and are accompanied by varying quantities of

${ }^{58}$ Parks, H. M., and Swartley; A. M., Mineral Resources of Oregon, vol. 2, No. 4, pp. 167-168, Oregon Bur. Mines and Geology, 1916. 
gold, which ranges from submicroscopic grains to flakes an eighth of an inch or more in diameter and small nuggets weighing as much as an ounce or more.

The formation of the original veins took place in three or four stages. Carbonates are the most abundant constituents and were deposited in three general stages, one preceding, one accompanying, and one following the principal sulphides. Quartz and the sulphides were formed mainly in one stage, which in some places may be divisible into two substages, but a second growth of pyrite took place after the second carbonate stage. The characteristic features of the minerals formed in the different stages are described below.

The first or principal carbonate stage is the least understood, as three distinct mineral species-calcite, dolomite, and a calcic rhodochrosite-are present. They all show the same relations to the quartz and sulphides of the second stage but have not been found in contact with one another. They have been distinguished microscopically and chemically by W. T. Schaller, of the United States Geological Survey. The early calcite forms veinlets and irregular coarse-grained masses, the veinlets being clearly replaced in part by sulphides and fine-grained quartz. The coarse-grained variety, according to chemical and optical $(\omega=1.672)$ tests, is estimated to contain about 6 per cent of manganese carbonate, 5 per cent of magnesium carbonate, and 1 per cent of iron carbonate. Replacement of this coarse-grained calcite by brown iron oxide and black manganese oxide is a feature of at least some of the rich "pockets" of ore on the surface.

The early dolomite is light gray and contains manganese and a little iron. As seen under the microscope it forms a network of platy crystals, darkly clouded by minute included specks, that are embedded in a clearer interstitial carbonate, which, to judge from optical and chemical data, is calcic rhodochrosite. The two carbonates were too thoroughly mixed for separate chemical determinations, and the platy crystals were too clouded to permit the determination of their index of refraction; but light-gray, early calcic rhodochrosite without the associated platy crystals was determined in other specimens, where its relations to quartz and sulphides were identical with those in the dolomitic specimen. Its $\omega$ index of refraction is $1.783-1.785$, and chemical tests show that it contains only traces of magnesium and iron.

Schaller ${ }^{59}$ has summarized the relation of crystal habit of calcite to relative temperature, pointing out that the platy variety of calcite denotes deposition at the highest temperature. It may therefore be tentatively inferred that the platy dolomite crystals, by

\footnotetext{
${ }^{50}$ Schaller, W. T., The crystal cavities of the New Jersey zeolite region: U. S. Geol. Survey Bull. 832, p. 47, 1932.
} 




GEOLOGIC SKETCH MAP OF GOLD HILL AND VICINITY, OCHOCO CREEK AREA, OREG.

Topographic base, supplied to G. F. Loughlin by United States Forest Service in 1914, was drawn from intersecting compass ahid aneroid traverses

\section{EXPLANATION}

$\because \because \therefore \because \because \because \because$

Alluvium
(Stream gravez)

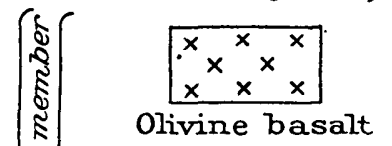

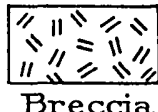

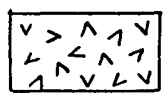

Porphyritic hyperstheneaugite andesite

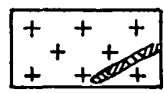

Dense andesite (including one dike)

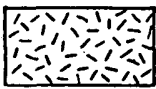

Porphyritic hornblende

andesite

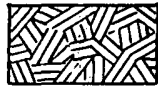

Andesite breccia

Areas without pattern

not studied.

Geologic traverse

$x$

Tunnel

$x$
Prospect 
analogy as well as by their relations to the rhodochrosite, sulphides, and quartz, were also deposited at relatively high temperature.

The second stage is characterized by a fine-grained quartz, commonly accompanied by carbonate (calcic rhodochrosite?) and pyrite and in the rich shoots by arsenopyrite, zinc blende, tetrahedrite, chalcopyrite, and galena. The quartz commonly has a minutely developed comb structure concealed beneath carbonate. It preceded the bulk of the pyrite, which was the earliest of the sulphides to form. The carbonate is similar to the calcic rhodochrosite of the first stage but was not sufficiently isolated or in large enough amounts to permit verification.

The pyrite is mostly very fine grained, but locally, in the highgrade ore, it forms cubic crystals as much as an eighth of an inch in diameter. It commonly lies along or near the margins of veinlets, where it has replaced carbonate. It has also coated the early carbonate and locally has alternated with second-stage carbonate in deposition. Carbonate-pyrite and quartz-pyrite veinlets may be present in the same microscopic section. Minute crystals of pyrite also form 6 -sided platy aggregates one-eighth of an inch or less in diameter. These have evidently coated platy crystals of early carbonate, presumably the dolomite described above. Subsequent removal of the carbonate has left small flat cavities in some of the aggregates; in others similar cavities have been filled by additional pyrite. These platy aggregates, as well as the other primary sulphides and gangue minerals, are in part coated by small clusters of flat rhombohedrons of carbonates belonging to the third stage.

Arsenopyrite in minute, typical light-gray prismatic crystals can be recognized in some specimens. It is closely associated with pyrite, but its exact relations were not determined. To judge from the percentage of speiss recorded in smelter analyses (p. 131), it is more abundant than available specimens of the ore would lead one to expect. No other arsenical minerals (except one small crystal of dark ruby silver?) have been recognized in the ore. Zinc blende forms medium to dark brown grains as much as 3 millimeters in diameter and like the pyrite is commonly present in the marginal parts of the veinlets. Chalcopyrite forms irregular grains 1 millimeter or more in diameter and is closely associated with zinc blende and pyrite. Tetrahedrite forms small fine-grained masses associated with the other sulphides. Very little galena was noted in the material available for study, although the small amounts of lead reported from a few shipments of ore and the galena found in local placers imply that galena may have been conspicuous in places. No visible gold has been reported from unenriched ore.

The third stage is marked by druses of platy carbonate crystals, which line vugs, especially in the high-grade ore. The specimens 
studied show that these drusy carbonates are similar in composition though somewhat purer than the early carbonates; for example, the platy crystals of rhodochrosite have a higher index of refraction $(\omega=1.790)$ than the early variety and evidently contain less calcium. The composition and mode of occurrence of these third-stage carbonates suggest that the material replaced by the sulphides and quartz was, in part at least, redeposited without appreciable transfer in solution; but scattered veinlets of pink dolomite, which contain little iron and only a trace of manganese and distinctly cut the sulphide veins, indicate that some transfer of material took place.

Deposition by descending surface water below the oxidized zone is most conspicuously represented by colorless calcite, fine drusy quartz, clay (montmorillonite), and secondary sulphides. The crystal form of this colorless calcite is the negative rhombohedron $e\{0112\}$, commonly called the "minus one-half form," which is characteristic of mineral deposits that have been permeated by surface waters. These rhombohedrons are best developed in vuggy veinlets, but the same mineral also forms small, compact, glassy veinlets that penetrate the most minute cracks in the original ore and gangue and unless recognized may lead to the impression that the primary vein material contains much more calcite than it really does.

The colorless, fine, drusy quartz is similar to the colorless calcite in general mode of occurrence but is not nearly so common. The clay (montmorillonite) also fills cracks and vugs in the ore and in part replaces carbonates.

The secondary sulphides include films of chalcocite, which forms black, sooty coatings, especially on chalcopyrite and zinc blende, also small clusters of hairlike crystals of jamesonite (?), occasional gray prismatic crystals of andorite, dark-red crystals of ruby silver (?), and colorless tabular crystals of valentinite, the orthorhombic form of antimony oxide $\left(\mathrm{Sb}_{2} \mathrm{O}_{3}\right)$. These minerals all occur in small cavities, some of which are due to the removal of carbonates of the third stage. The jamesonite (?) was tentatively determined by Schaller, who stated that most of the hairlike fibers have a basal cleavage and are brittle and not flexible but that a few "hairs" lacked basal cleavage, were extremely flexible, and evidently represented some other mineral. ${ }^{60}$ Measurements of the angles of prism faces on one fiber with basal cleavage gave results agreeing with the prism angles of jamesonite.

The oxidized ore is characterized by honeycombed vein material stained brown and black by iron and manganese oxides and by earthy masses of those oxides that have replaced the carbonates and sulphides in local enlargements of veins and have formed the

${ }^{60}$ Schaller describes a similar mixture with crystals of jamesonite (Mineralogical notes, series 1: U. S. Geol. Survey Bull. 490, p. 27, 1911). 
rich superficial "pockets." Some cavities in the black earthy oxides are lined with white, drusy aragonite. Free gold, commonly associated with the two oxides, forms specks, flakes, and nuggets loosely adhering to vein quartz and easily recovered by crushing and panning. The oxidized ore extends only a few feet below the surface.

Metal production from the area as a whole can not be definitely correlated with different varieties of ore. The average content of gold is 1.1 fine ounces and that of silver 4.2 fine ounces to the ton. Lead was reported in only three annual shipments and ranged from 0.6 to 1.2 per cent. The gold-silver ratios, including "pocket" ore and high-grade enriched sulphide ore, range from 1:0.04 to $1: 4$ in shipments for which no lead was reported and from $1: 4$ to $1: 12.5$ in those containing lead. One exceptional shipment of 15 tons showed a ratio of $1: 87$, but it is possible that this shipment came from some other place in Crook County. The gold-silver ratio in shipments from placers ranged from 1:0.06 to $1: 0.27$, and averaged 1:0.16. Its close similarity to the ratio in the "pocket" and vein ores accords with the geologic evidence that the placer gold is of strictly local origin.

Assays of individual lots of ore from the Ophir-Mayflower lode, exclusive of any rich, oxidized "pockets," show a gold content in general of as much as 2.28 ounces to the ton and a silver content of as much as 35 ounces to the ton, but they show no consistent ratio between gold and silver or between silver and lead. Exceptional small shipments, which may have come from a surface "pocket," contained 21.85 ounces of gold and 12.8 ounces of silver to the ton. Representative smelter analyses made in 1913 and 1914 follow:

Smelter analyses of ores from Ophir-Mayflower lode.

\begin{tabular}{|c|c|c|c|c|c|c|}
\hline \multirow{2}{*}{. } & \multirow{2}{*}{$\begin{array}{c}\begin{array}{c}\text { Sulphide } \\
\text { (pyrite } \\
\text { concen- } \\
\text { trates) }\end{array} \\
1\end{array}$} & \multicolumn{2}{|c|}{ Sulphide (crude) } & \multicolumn{3}{|c|}{ Oxidized (crude) } \\
\hline & & 2 & 3 & 4 & 5 & 6 \\
\hline $\begin{array}{l}\text { Gold. } \\
\text { Silver } \\
\text { Lead } \\
\text { Insoluble } \\
\text { Zinc } \\
\text { Sulphur } \\
\text { Speiss. } \\
\text { Iron } \\
\text { Manganese do dont. } \\
\text { Copper } \\
\text { Water }\end{array}$ & \begin{tabular}{|c|}
1.73 \\
17.0 \\
Not det. \\
5.0 \\
1.7 \\
37.0 \\
Not det. \\
36.8 \\
2.5 \\
Not det. \\
1.0
\end{tabular} & $\begin{array}{r}1.44 \\
31.27 \\
1.1 \\
14.8 \\
1.4 \\
18.6 \\
9.5 \\
15.4 \\
17.3 \\
\text { None. } \\
2.2\end{array}$ & $\begin{array}{r}1.99 \\
25.85 \\
1.2 \\
12.7 \\
2.1 \\
17.4 \\
3.6 \\
13.4 \\
17.9 \\
\text { None. } \\
4.7\end{array}$ & $\begin{array}{c}6.20 \\
9.4 \\
\text { None. } \\
10.6 \\
\text { None. } \\
4.5 \\
\text { None. } \\
8.8 \\
28.2 \\
\text { Not det. } \\
9.5\end{array}$ & $\begin{array}{c}4.02 \\
10.2 \\
\text { None. } \\
9.8 \\
\text { None. } \\
2.4 \\
\text { None. } \\
6.4 \\
32.7 \\
\text { None. } \\
6.2\end{array}$ & $\begin{array}{l}21.50 \\
12.7 \text {. } \\
\text { None. } \\
41.0 \\
\text { None. } \\
1.3 \\
\text { None. } \\
22.0 \\
5.5 \\
\text { None. } \\
20.1\end{array}$ \\
\hline
\end{tabular}

These analyses conform very well to the mineral composition of the ore as described above. Calculation of 'sulphides in the rich 
crude sulphide ore shows the content of galena to be about 1.4 per cent, that of zinc blende 2.1 to 3.2 per cent, and pyrite 29 to 33 per cent. The percentage of speiss implies somewhat more of the sulpharsenides of silver and copper than was found in material accessible to the writer. The manganese is mainly present in the carbonates, and the water mainly in clay minerals. The ore represented by analyses 4 and 5 is evidently a mixture of manganiferous carbonate and oxide with a small amount of pyrite, and that of analysis 6 is a mixture of iron and manganese oxides, clay, and quartz.

The thoroughly altered pyritic rock of Gold Hill has been regarded as possible mill ore. Its range in composition in the Ophir-Mayflower tunnel, exclusive of high-grade veinlets, is 0.02 to 0.24 ounce of gold and 0.2 to 5.0 ounces of silver to the ton. An average of 34 assays, including seven of relatively high-grade material and stated to represent the run of the Ophir-Mayflower lode, gives 0.411 ounce of gold and 6.67 ounces of silver to the ton.

The sequence of processes controlling ore deposition is summarized below. The Clarno(?) formation, soon after its deposition, was elevated and fractured, and, where fracturing was especially pronounced, it gave access to vein-forming solutions. There is no positive information on the source of these solutions, but in composition and character the deposits are similar to many deposits formed at shallow depths in Tertiary volcanic rocks. The solutions evidently came from a deep-seated source, rose and dispersed along a network of intersecting fractures, permeated the local andesite, and altered it thoroughly to the bleached pyritic rock. This permeation marked the first and most intense stage of mineralization. Subsequent stages were marked by the deposition of barren calcite veins and masses followed by deposition of primary ore minerals with quartz and carbonate. The ore minerals for the most part were confined to narrow veinlets, but where shattering was intense, especially at the junctions and intersections of fissures, they were deposited in sufficient quantity to form small ore shoots. The wall rock and especially the early, barren calcite were replaced to some extent along these shoots, but the relative importance of shattering and replacement could not be determined from the meager evidence available.

These shoots contained small amounts of silver minerals and doubtless primary gold, but the value of the rich ore was brought about to a considerable extent by downward enrichment, which probably began soon after the veins were formed. If so, it was probably interrupted by the renewed volcanic activity that covered most of the regions with the later horizontal basalt flows. The lowest of these flows in the vicinity may have covered Gold Hill less than 200 
feet above its present summit. Renewed erosion removed this basalt and developed the present local drainage system. Downward enrichment was resumed.

The solution and redeposition of gold were evidently favored by the abundance of manganiferous carbonate. The manganese oxide derived by the weathering of the carbonate aided in the solution of gold at the outcrop, and the unweathered carbonate, together with chalcocite and zinc blende, was promptly precipitated on its downward course. When these enriched shoots in turn became exposed at the surface and subjected to weathering, the cycle of solution and redeposition was repeated; but recent erosion has been so rapid that it has almost kept pace with oxidation, and much if not most of the gold, before it could be dissolved, has been washed down the slopes to form placers.

The placers, according to the evidence at hand, the topographic map, and the inferred erosion of Gold Hill since the removal of its basalt cap, represent concentration from a thickness of 200 to 400 feet of mineralized ground. Small stretches along Scissors Creek had not been worked up to 1914, and the recorded production from placers may represent less than half the total placer gold; but even so, the quantity remaining and the conditions affecting operation justify work only on a small, intermittent scale. The quantity of oxidized and enriched sulphide ore shipped from veins and "pockets" may be regarded as a conservative representation of the shipping ore that was available above the level of the OphirMayflower tunnel. Other "pockets" on the surface doubtless remain to be found and may be profitably worked by individuals. Other shoots may exist underground, but those already found are in the most intensely altered ground, and only smaller and more intermittent output could be expected from any others. There is no reason why primary ore shoots should not exist well below the Ophir-Mayflower tunnel, but they are less likely to be enriched than those above the tunnel level, and mining any considerable distance below the tunnel level will involve pumping.

Ophir-Mayflower.-The Ophir-Mayflower mine is on the west slope of Gold Hill adjoining Ochoco camp. It is opened. by a main tunnel which extends from a point near creek level for about 1,475 feet in a direction averaging S. $57^{\circ} \mathrm{E}$. (see fig. 21), by a short tunnel about 200 feet up the slope, and by several shallow pits made in the search for "pockets" of oxidized ore.

The date of the discovery is not known, but it may have been as early as 1885 , the date of the earliest recorded production in the area. According to data supplied by V. C. Heikes, of the United, 
States Bureau of Mines, the mine was worked intermittently between 1903 and 1923. It was productive in each year from 1912 to 1918, when annual production ranged from 24 to 919 tons of crude

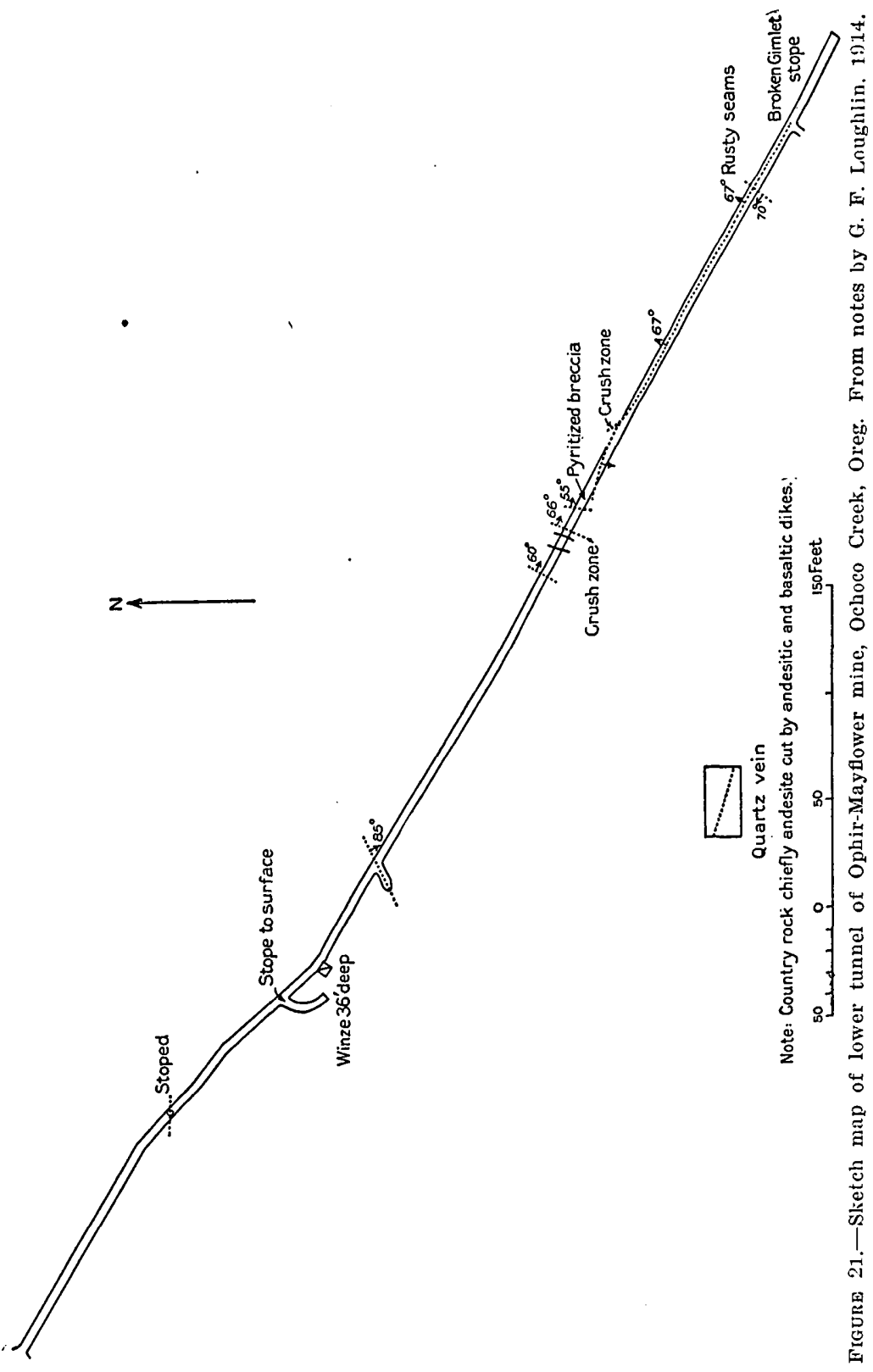

ore, most of which averaged more than an ounce of gold and 5 ounces of silver to the ton, although single shipments gave much higher returns. A 10-ton stamp mill with Wilfley table and amalgamating 
plates was erected in 1906 and operated at intervals. Shipments have included crude ore and concentrates to smelters, crude ore to gold and silver mills, and bullion from the mill at the mine.

The country rock is dense to porphyritic andesite, which has been thoroughly bleached by alteration and impregnated by fine grains of pyrite along the network of veinlets described on pages 126-127.

Locally and at least at some intersections of narrow veins highgrade ore shoots have formed. The first of these is 225 feet from the portal and is called the True Augur or Mary Davenport vein. It crosses the drift in an easterly direction, dips vertically, and has a visible maximum width of $11 / 2$ feet just above the tunnel. It has been stoped only a short distance above the tunnel. The ore remaining on the tunnel level in 1914 consisted of soft pyrite veinlets that were said to mill readily to concentrates averaging $\$ 42$ to the ton. The second shoot cut by the lower tunnel is about 500 feet from the portal. It has been followed in a winze for 36 feet below tunnel level and is said to have been stoped continuously from the surface. This is probably the stope mentioned by Parks and Swartley as having a vertical length of 250 feet, a horizontal length of 70 feet, and a width of 1 to 6 feet. Its trend could not be determined from the tunnel level, but according to a blue print of the property furnished by Don Maguire, of Ogden, Utah, it trends northeastward at about right angles to the course of the tunnel. Its upper part was evidently reached by a northeast drift from the upper tunnel. Ore from it is said to have averaged about $\$ 70$ to the ton, although its highest-grade sample assayed $\$ 625$ to the ton. The richer ore was of "black sooty" character, which implies the presence of either black manganese oxide or zinc blende and other sulphides coated with chalcocite. Both the oxide and the sulphides imply a relatively high content of gold.

A third shoot, called the Broken Gimlet shoot, was found in 1902 and was stoped upward for 25 or 30 feet from a short south drift 200 feet from the breast of the tunnel. Dirt mucked out of this stope in 1912 or 1913 was put through the local mill, and its concentrates assayed $\$ 38$ to the ton. The shoot is underlain on the tunnel level by intersecting, partly oxidized veinlets parallel to and crossing the tunnel. Their unoxidized material is similar in composition to the veinlets throughout the mine, though perhaps with a greater than average content of zinc blende.

Surface workings examined above the tunnels include that at the outcrop of the second ore shoot cut by the lower tunnel and a "pocket" 150 feet southwest of it. The outcrop of the ore shoot consisted of "pockets" of black to brown manganese and iron oxides, which passed downward into shattered rock cemented by veinlets 
composed of carbonate, pyrite, and zinc blende. No main fissure was noted, About 20 feet below the outcrop an incline sloping about $60^{\circ} \mathrm{E}$. was sunk along ore and is said to have continued nearly to the lower tunnel level, above which another shoot of southeasterly pitch is said to have been found.

The "pocket" to the southwest, called "Ellif's diggings," was located in 1913 by a Mr. Ellif, by panning the surface débris. $\mathrm{He}$ first found a black veinlet or "seam" that dipped about $15^{\circ}$ into the hill and opened into a pocket 10 feet long, 6 to 7 feet wide, and 8 inches to a foot thick, from which he took about $\$ 5,000$. Material along this seam consists of bleached and dark stained porous rock with small vugs partly filled with the iron-magnesium carbonate, mesitite. The "seam," opened by a 30 -foot incline, continued into the hill but changed to a veinlet of calcite-pyrite-zinc blende ore that assayed about $\$ 75$ to the ton in gold. This veinlet pinched, but the tight fracture continued to a vertical crushed zone trending N. $55^{\circ} \mathrm{W}$. and as much as 1 foot thick. Both the crushed zone and the tight fracture were accompanied by pyritic "mill rock." Some of this rock was milled in 1914, but its gold content was not learned.

Other workings on Gold Hill.-The Brian O'Lynn tunnel enters the southeast base of Gold Hill opposite the junction of Scissors Creek with its north fork. It trends N. $70^{\circ} \mathrm{W}$. and follows poorly to well defined fissure walls for about 360 feet. The tunnel walls are bleached all the way and here and there show small patches and seams of pyrite, but the effects of mineralization are not nearly so marked on the whole as in the Ophir-Mayflower tunnel. About 150 feet from the portal a crosscut 6 feet long exposes two parallel thin, rusty seams. The last 50 feet of the tunnel follows a seam that looks rather promising at the breast.

The Scissors Bill tunnel trends N: $7^{\circ} \mathrm{E}$. for 30 feet into the south base of Gold Hill. It is all in surface débris except at the breast, where soft gray pyritic anclesite is exposed.

The Street tunnel, the largest development along the south base of Gold Hill, extends N. $6^{\circ} \mathrm{W}$. for about 360 feet. This tunnel also is in pyritic rock about all the way, although considerable unbleached rock is cut near the portal. A zone of iron-stained fractures is cut about 110 feet from the portal, and 50 to 55 feet farther in is a spherical "pocket" of fractures and impregnated rock. The breast of the tunnel is in bleached pyritic rock containing siliceous nodules with conspicuous streaks of fine-grained pyrite. The nodules are spherical to elongate and reach 1 foot in maximum diameter.

A "pocket" on the surface 150 feet above the Street tunnel consists of dark-brown earthy manganese-iron oxide that has replaced coarse-grained calcite and pyritic vein material. Small vugs in the earthy oxide are lined with fine, drusy aragonite. 
About 40 feet west of this "pocket" a prospect discloses a group of horizontal veinlets with associated nodules of flinty quartz impregnated by pyrite. The veinlets are partly oxidized to soft, sooty manganese-iron oxide typical of high-grade ore and may lead to a high-grade pocket.

The Little Giant prospect, about 500 feet east of the Street tunnel and 100 feet above it, is opened by a tunnel that trends $\mathrm{N} .70^{\circ} \mathrm{W}$. for 15 feet. It exposes a fissure bordered by red and black ironmanganese earth in leached pyritic rock.

The westernmost prospect noted was near the mouth of Scissors Creek, where a short tunnel with a 12 -foot winze, full of water, is said to have opened a little high-grade ore.

Red Bird Hill.-Several openings have been made on Red Bird Hill, which lies between Scissors Creek and Wadkins Gulch. Pronounced mineralization there has taken place along a zone 50 feet wide, which trends $\mathrm{N} .70^{\circ} \mathrm{E}$. and has a dike of brecciated dense andesite dipping $65^{\circ}-75^{\circ} \mathrm{S}$. for a hanging wall. The footwall is concealed by soil and vegetation. The unoxidized rock within the zone is bleached, impregnated with fine-grained pyrite, and cut by seams of coarser-grained pyrite and chalcopyrite. The dike and the porphyritic andesite on its south side are only mildly altered. They retain their dark-gray color but are impregnated by microscopic quartz and especially by calcite, chlorite, and sericite or montmorillonite, accompanied by minute grains of pyrite.

The individual veinlets and "pockets" do not conform to any definite system. The promising veinlets are oxidized. They contain small quartz crystals, some with distinct comb structure, that are coated with black manganese oxide and have minute specks of gold adhering to them. These veinlets locally open into pockets from a few inches to 3 feet in width in which the gold occurs as flakes and nuggets.

The workings on Red Bird Hill include two short tunnels, a shaft said to be 65 feet deep, and several small surface diggings. None of the underground workings were examined.

Placers.-The principal placer operations, all small, have been conducted along the lower part of Scissors Creek, which crosses the mineralized area. The diggings extend a short distance above Wadkins Gulch. Minor operations have been undertaken along Stevenson Gulch, which bounds Gold Hill on the north, and in shallow washes on the west slope of Gold Hill. - Scissors Creek supplies sufficient water for placer mining during March, April, and May, and additional supplies have been obtained by ditches. The two lower ditches along the west slope of Gold Hill (pl. 8) lead from Ochoco Creek, and the highest ditch leads from an old reservoir in section 21 , more 164495-33- - 10 
than 2 miles away. Another ditch leads from Judy Creek in section 31 to the head of Wadkins Gulch.

The gold is distributed to a minor extent throughout the coarse, angular creek gravel, but is mainly concentrated in crevices in the uppermost foot or two of the underlying bedrock. The distribution of pay streaks is spotty. One noteworthy streak, on the Robertson placer claim, coincides with a low shelf on the bedrock surface. Gold produced from this claim in 1911-1913 amounted to 66 ounces.

The gold is largely in flakes, but nuggets worth as much as $\$ 29$ have been reported. It is not much waterworn, contains considerable silver, as shown on page 125, and is accompanied by small lumps of fresh pyrite and carbonate-coated galena. These features also point to the strictly local derivation of the placer gold.

\section{MAURY MOUNTAIN AREA}

Staley \& Towner.-The quicksilver prospects of J. E. Staley and Frank Towner are on Maury Mountain, southeast of Post, on the Crooked River, in sec. 10, T. 17 S., R. 19 E. The claims are about 30 miles from Prineville by way of the Crooked River Highway. Five claims form the group, all located in the summer of 1930.

Two shallow cuts, about 200 feet apart, have been made on the nose of a ridge. They expose small stringers and impregnations of cinnabar in a volcanic rock, apparently an andesitic or basaltic flow breccia, of Tertiary age. Chalcedony, quartz, and calcite accompany the cinnabar. Not enough work had been done at the time of visit to outline the possibilities of the deposit.

\section{BEAR CREEK AREA}

Wiltsie \& Platner.-Quicksilver prospects held by Lloyd Wiltsie and his brothers, Frank Platner, and their associates are distributed along a considerable belt in secs. 18 and 19, T. 18 S., R. 17 E., on the hills west of Bear Creek, about 7 miles south of its junction with the Crooked River. The claims are about 20 miles from Prineville over the Crooked River Highway. Altogether about a dozen claims have been staked in this locality.

The country rock is Tertiary andesite and porphyritic andesite with a little tuff. The attitude of the series was not accurately determined, but it is probably nearly flat. A quartz lode, consisting of numerous reticulating veinlets of quartz, cuts these volcanic rocks. This lode stands in relief above the country rock and forms the backbone of a long hill. For about a quarter of a mile near the north end the ridge is interrupted, presumably because the lode is weakly developed there. 
The lode strikes N. $30^{\circ} \mathrm{W}$. at its north end but swings to $\mathrm{N}$. $10^{\circ} \mathrm{W}$. at the south. Individual veins strike and dip in nearly every direction, but most of them strike in the northwest quadrant and dip steeply. At least two definite spurs branch from the main lode but do not seem to be very persistent.

The lode ranges in width from a foot or so up to about 10 feet, but its silicified border zone, composed of less numerous quartz veinlets, is as much as 50 feet in width and only locally is less than 5 feet wide.

Accompanying the quartz are much chalcedony and opal and considerable kaolin and montmorillonite. The development of the clay minerals results in a bleached zone in the country rock. Pyrite and cinnabar impregnate the silicified zone and a little asphalt occurs in vugs in the veinlets. The cinnabar is richest in the quartz veinlets but also occurs disseminated in the walls.

The Wiltsie brothers had two open cuts on the lode and a short tunnel started to cut the lode at depth. Mr. and Mrs. Frank Platner had explored their claims by several open cuts and a short tunnel, which had not been driven through the lode in August, 1930. Enough work had been done along the lode, however, to demonstrate the widespread occurrence of cinnabar but not enough to justify an estimate of the commercial possibilities of the deposit.

Dunham.-C. C. Dunham had done some prospecting on a small tributary of Bear Creek, in sec. 31, T. 17 S., R. 17 E., and had located three claims.

The country rock is porphyritic andesite of Tertiary age cut by quartz veins similar to those on the Wiltsie and Platner claims. The cinnabar occurs in seams and veinlets along the quartz veins. The lode, which strikes $\mathrm{N} .40^{\circ} \mathrm{W}$. and dips steeply west, may be a continuation of the. Wiltsie lode 2 miles south, but this is not established. In a small cut a vein striking N. $20^{\circ} \mathrm{W}$. and dipping $85^{\circ} \mathrm{W}$. is exposed. The cinnabar is accompanied by pyrite, much calcite, dolomite, beidellite, kaolin, and chalcedony. Some nontronite also occurs, and a little asphalt fills vugs in the quartz veins.

The prospecting done up to the time of visit had been confined to surface trenches and did not suffice to give any adequate idea of the commercial possibilities of the deposit.

\section{OUTLOOK FOR THE DISTRICT}

The quicksilver deposits in the vicinity of Prineville offer considerable promise of production on a small scale. Future developments may well reveal larger bodies of ore, which can be worked on a more elaborate scale, but at the time the several properties 
were examined none had yet shown large reserves. Nevertheless, several were very promising, and careful work, with a minimum of overhead in the operating costs and with efficient condensing apparatus, should make them profitable in a moderate way. Although the properties are not very favorably located for railway transportation, this disadvantage is not so serious to quicksilver mines as to others, because of the ready reduction of the ores and the compactness of the product that must be transported. Several of the properties are favorably situated for cheap fuel, because of the proximity of sawmills with much rejected wood that can be had at low cost. 